MÔNICA MEDEIROS

PÓS-TRATAMENTO DE EFLUENTE DE LAGOA FACULTATIVA FOTOSSINTÉTICA EM FILTROS BIOLÓGICOS PERCOLADORES VISANDO REMOÇÃO DE NITROGÊNIO AMONIACAL

Dissertação apresentada à Escola Politécnica da Universidade de São Paulo para Obtenção do Título de Mestre em Engenharia

São Paulo 
MÔNICA MEDEIROS

\title{
PÓS-TRATAMENTO DE EFLUENTE DE LAGOA FACULTATIVA FOTOSSINTÉTICA EM FILTROS BIOLÓGICOS PERCOLADORES VISANDO REMOÇÃO DE NITROGÊNIO AMONIACAL
}

\begin{abstract}
Dissertação apresentada à Escola Politécnica da Universidade de São Paulo para Obtenção do Título de Mestre em Engenharia
\end{abstract}

Área de Concentração:

Engenharia Hidráulica e Sanitária

Orientador:

Prof. Dr Roque Passos Piveli

São Paulo 
Este exemplar foi revisado e alterado em relação à versão original, sob responsabilidade única do autor e com a anuência de seu orientador.

São Paulo, 25 de Maio de 2011.

Assinatura do autor

Assinatura do orientador

FICHA CATALOGRÁFICA

Medeiros, Mônica

Pós-tratamento de efluente de lagoa facultativa

fotossintética

em filtros biológicos percoladores visando remoção de nitrogênio amoniacal / M. Medeiros. -- São Paulo, 2011.

$132 \mathrm{p}$.

Dissertação (Mestrado) - Escola Politécnica da Universidade

de São Paulo. Departamento de Engenharia Hidráulica e Sanitária.

1. Tratamento de esgotos sanitários 2 . Filtros biológicos 3. Tratamento biológico de aeróbio 4. Remoção de nutrientes I. Universidade de São Paulo. Escola Politécnica. Departamento de Engenharia Hidráulica e Sanitária II. t. 


\section{MÔNICA MEDEIROS}

Pós-tratamento de efluente de lagoa facultativa

Fotossintética em filtros biológicos percoladores

Visando remoção de nitrogênio amoniacal

Dissertação apresentada à Escola Politécnica da Universidade de São Paulo para Obtenção do Título de Mestre em Engenharia

Área de Concentração: Engenharia Hidráulica e Sanitária

Aprovada em: 01/04/2011

\section{Banca Examinadora}

Prof.Dr.: Roque Passos Piveli

Vínculo: EP - USP

Assinatura:

Prof.Dr.: Bruno Coraucci Filho

Vínculo: Unicamp

Assinatura:

Prof.Dr.:Sidney Seckler Ferreira Filho

Vínculo: EP - USP

Assinatura: 
Dedicatória

À minha querida e sempre amiga, Aline Akabochi Fabreti, mulher batalhadora que me incentivou a seguir nessa area e me ajudou a me tornar uma pessoa melhor. Mesmo do céu, você sempre estará presente. Sinto sua presença todos os dias! 


\section{AGRADECIMENTOS}

Primeiramente, agradeço a Deus por ter me dado a oportunidade de estar no mundo;

Aos meus pais José e Fátima e meu irmão Wellington, agradeço por todo o amor, carinho, respeito e compreensão, vocês são a minha base, meu porto seguro, meus amores incondicionais;

Ao meu orientador, Prof. Dr. Livre Docente Roque Passos Piveli, pela orientação, dedicação, incentivo, apoio ao longo desta pesquisa e também pela oportunidade concedida de cursar o mestrado em Engenharia Hidráulica e Sanitária na Escola Politécnica da USP;

Ao "fiel escudeiro" Humberto Ruggeri, companheiro de pesquisa, pelo apoio, ajuda e incentivo;

Ao Prof. Luis Fernando Rossi Léo, que na graduação me apresentou bibliografias da área de saneamento e me incentivou a seguir nesta área. Minha escolha profissional pela área de saneamento deve-se muito a você;

Ao Mauricio Bernardi, pela forte amizade e grande colaboração no campo de pesquisa, no laboratório e por estar sempre disposto a me ajudar da melhor maneira possivel; 
À Unilins, ao PHD-USP e em especial a toda a equipe do Laci, que disponibilizarm o laboratório para realização das análises desta pesquisa;

Aos amigos da USP, da Unilins, da White Martins Soluções Ambientais e da Siemens Water Technologies, pela amizade e por sempre compreenderem a importância deste trabalho na minha vida;

Ao PROSAB e todos os bolsistas envolvidos, por permitirem 0 desenvolvimento deste estudo;

A todos que colaboraram direta ou indiretamente para a concretização deste trabalho.

Muito obrigada a todos! 


\section{RESUMO}

Neste trabalho, estudou-se a utilização de filtros percoladores como tratamento complementar de efluente de lagoa de estabilização visando a remoção de nitrogênio, principal causador de problemas como a eutrofização de corpos hídricos em conjunto com o fósforo. A motivação principal para o desenvolvimento desta pesquisa foi a dificuldade encontrada para o atendimento ao padrão definido pela Resolução CONAMA 357/05, a qual define concentração máxima de nitrogênio para lançamento de efluentes em corpos hídricos receptores de $20 \mathrm{mg} / \mathrm{l}$. Em 2008 foi promulgada a Resolução CONAMA n 397 a qual estabeleceu, em seu Artigo 34, que o padrão de emissão de nitrogênio amoniacal seria suspenso temporariamente para efluentes de estação de tratamento de esgoto sanitário, continuando a valer a concentração máxima nos corpos receptores estabelecidas na Resolução CONAMA 357/05. Sendo assim, a questão sobre a remoção de nutrientes constitui uma preocupação diretamente relacionada ao emprego dos sistemas de lagoas de estabilização.

Para esta pesquisa, utilizou-se os efluentes tratados por lagoas facultativas provenientes da Estação de Tratamento de Esgoto do município de Lins/SP e, para o experimento em questão, foram construídos dois filtros biológicos seguidos de decantadores, ambos em escala piloto.

Os filtros foram construídos em um corpo cilíndrico de polipropileno com diâmetro de 1,2 metros e teve seu volume dividido igualmente por uma placa vertical também de polipropileno, propiciando área superficicial de $1,13 \mathrm{~m}^{2}$ e volume útil total de 4,52 $\mathrm{m}^{3}$. Para o fornecimento de oxigênio, indispensável para o processo de nitrificação, o filtro foi apoiado sobre uma base de concreto com drenos de fundo para permitir a ventilação do sistema, garantindo a concentração de oxigênio necessária.

Para comparação da eficiência na remoção do nitrogênio, cada filtro foi preenchido com determinado tipo de material, ou seja, um filtro continha 
pedra britada variando de 4 a 8 , adminitindo-se área superficial de 70 $\mathrm{m}^{2} / \mathrm{m}^{3}$ e possibilitando uma área para formação de biofilme de $316,7 \mathrm{~m}^{2}$, enquanto que no outro filtro foram utilizado anéis plásticos com área superficial de $100 \mathrm{~m}^{3} / \mathrm{m}^{3}$, fornecendo $542,9 \mathrm{~m}^{2}$ de área superficial para a formação de biofilme. Também foram construídos decantadores após os filtros percoladores para a remoção dos sólidos em suspensão, não sendo alvo da pesquisa em questão

Tendo em vista que o molhamento de todo o material de preenchimento se faz importante para a eficiência do sistema, foi utilizado um sistema de recalque para o transporte do esgoto para o filtro, distribuído continuamente sobre o meio suporte e com vazão divida igualmente para os dois filtros por meio de um sistema de distribuição de pvc perfurado com diâmetro de $40 \mathrm{~mm}$ e com funcionamento semelhante a um aspersor de jardim

A taxa de aplicação superficial variou entre baixa, intermediária e alta, tendo aumento de vazão no sistema até que o processo de nitrificação cessasse e cada fase teve duração de 180 dias.

Conforme verificado nos resultados obtidos, filtros percoladores apresentam boa eficiência na remoção do nitrogênio do efluente, seja pela desnitrificação via nitrito ou pela volatilização do nitrogênio. A ETAPA 1 apresentou resultados bastante satisfatórios para o filtro de brita em relação ao filtro com anéis plásticos, podendo ter sido ocasionado pela área rugosa das britas, a qual facilitou a formação do biofilme, enquanto que a superfície lisa dos anéis plásticos dificulta a formação do biofilme, resultando na baixa eficência apesar da maior área superficial. Já na ETAPA 3, com taxas de aplicação maiores, o filtro preenchido com anéis plásticos apresentou maior eficiência do que o filtro com brita. Tal fato pode ter sido conseqüência da maior área disponível para a formação do biofilme nos anéis plásticos.

Ambos os casos apresentaram eficiência suficiente para remoção de nitrogênio a concentrações inferiores a $20 \mathrm{mg} / \mathrm{l}$. Tais resultados demonstram que os filtros percoladores possuem boa funcionalidade para a remoção do nitrogênio de efluente sanitário tratado por sistemas de lagoas de estabilização. 


\begin{abstract}
It was studied in this paper the use of trickling filters as a complementary treatment of wastewater stabilization pond seeking removal of nitrogen, the main cause of problems such as eutrophication of water bodies in conjunction with phosphorus. The main motivation for this research was the difficulty to meet the standard set by CONAMA 357/05 Resolution, which defines the maximum nitrogen concentration for disposal of effluents in water bodies as $20 \mathrm{mg} / \mathrm{I}$. In 2008 was created the CONAMA Resolution 397 which established, in Article 34 that the emission pattern of ammonia nitrogen would be temporarily suspended for wastewater treatment plant discharge, continuing to enforce the maximum concentration in the water bodies established in CONAMA Resolution $357 / 05$. Thus, the question on the removal of nutrients is a concern related to the use of systems of waste stabilization ponds.

For this study, was used the treated effluent by anaerobic and facultative ponds from the Sewage Treatment Plant in the city of Lins/SP, and for this experiment was constructed two trickling filters followed by settlers, both in pilot scale.
\end{abstract}

The filters were constructed on a cylindrical body of polypropylene with a diameter of 1.2 meters and its volume was divided symmetrically by a vertical plate also made of polypropylene, providing superficicial area of $1.13 \mathrm{~m}^{2}$ and total net volume of $4.52 \mathrm{~m}^{3}$. To supply oxygen, essential for the nitrification process, the filter was supported on a concrete base with bottom drains to allow the ventilation system, to suply the concentration of oxygen needed.

To compare the efficiency of nitrogen removal, each filter was filled with a certain type of material, ie, a filter containing crushed rock ranging from 4 to 8 , considering surface area of $70 \mathrm{~m}^{2} / \mathrm{m}^{3}$ and a possible area for biofilm formation of $316.7 \mathrm{~m}^{2}$, while in the other filter was used plastic rings with surface area of $100 \mathrm{~m}^{2} / \mathrm{m}^{3}$, providing $542.9 \mathrm{~m}^{2}$ of surface area for biofilm formation. Settlers were constructed after the trickling filters for the removal of suspended solids, because that are not the focus of this 
research. Considering that the wetness around the filling material is important for system efficiency, it was used a pumping system to transport sewage to the filter, continuously distributed on the support materials and flow split equally for both filters by a distribution system made of perforated PVC with a diameter of $40 \mathrm{~mm}$ and functioning like a garden sprinkler.

The application rate surface ranged from low, intermediate and high, having increased flow in the system until the process of nitrification ended and each phase lasted 180 days.

As shown in the results, trickling filters show good efficiency in removing nitrogen from wastewater, either by denitrification by nitrite or by the volatilization of nitrogen. The STEP 1 showed satisfactory results for the filter of crushed rocks over the filter with plastic rings, which may have been caused by the rocks rough area, which facilitated the formation of biofilms, while the smooth surface of the plastic rings makes harder the formation of biofilm, resulting in low efficiency despite the larger surface area. In STEP 3, with higher rates of application, the filter filled with plastic rings showed higher efficiency than the filter with crushed rocks. This might have been a consequence of the greater area available for biofilm formation in plastic rings.

Both cases had efficient enough to achieve nitrogen concentrations lower than $20 \mathrm{mg} / \mathrm{l}$. These results demonstrate that the trickling filters have good functionality for removing nitrogen from sanitaty wastewater treated systems for waste stabilization ponds. 


\section{SUMÁRIO}

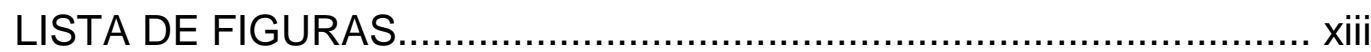

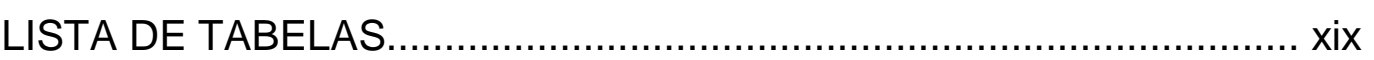

LISTA DE ABREVIATURAS ...................................................... xxi

LISTA DE SÍMBOLOS .................................................................. xxii

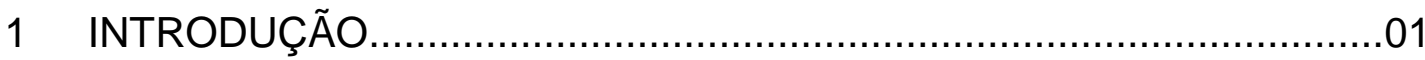

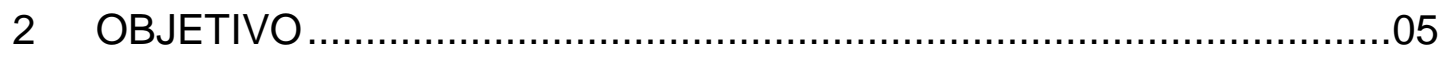

$2.1 \quad$ Objetivo Geral...................................................................

2.2 Objetivos específicos...........................................................

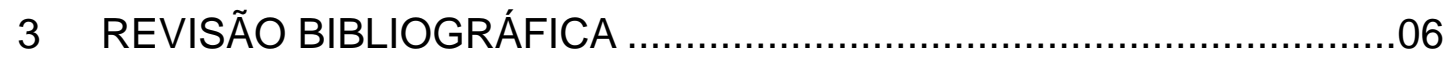

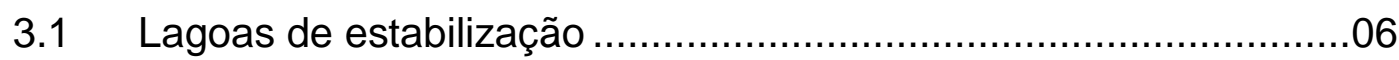

3.1.1 Lagoa Anaeróbia ............................................................

3.1.2 Lagoa Facultativa .........................................................10

3.2 Pós-tratamento de efluentes de lagoas de estabilização ...............14

3.3 Presença de Algas no Efluente de Lagoas de Estabilização...........15

3.4 Reuso Agrícola do Efluente de Lagoas de Estabilização ...............17

3.5 Fundamentos da Nitrificação Biológica ...................................20

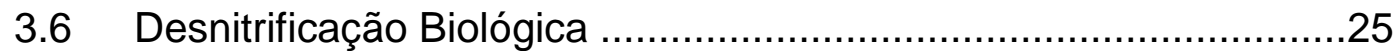

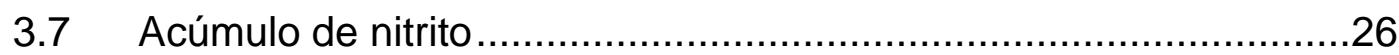

3.8 Filtros Biológicos Percoladores .........................................30

3.8.1 Aspectos Gerais e Princípios de Funcionamento ...................30 
3.8.2 Aspectos Gerais Sobre a Formação do Biofilme em Meio

Suporte .32

3.8.3 Classificação dos Filtros Biológicos....................................34

3.8.4 Parâmetros de Projeto que Interferem na Nitrificação de FBPs.. 36

3.8.5 Desempenho de FBPs na Remoção de Nitrogênio Amoniacal.

3.8.6 Materiais de Preenchimento Utilizados em FBPs .42

3.9 Filtro Biológico Percolador como Pós Tratamento de Efluentes de Lagoas de Estabilização .....

3.9.1 Aplicabilidade da Tecnologia na Remoção de Amônia .45

3.9.2 Desempenho de Filtros Biológicos Operando como Pós Tratamento de Efluentes de Lagoas....

4 MATERIAL E MÉTODOS .50

4.1 Descrição da Estação de Tratamento de Esgoto de Lins - SP .......50

4.2 Descrição das Instalações do Campo Experimental .......................52

4.3 Etapas Experimentais e Condições Operacionais.........................62

4.4 Análises Físico-químicas e Técnicas Analíticas ............................63

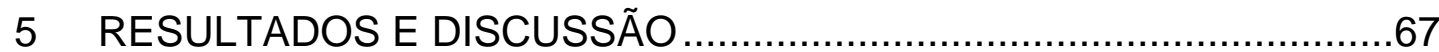

5.1 Resultados apresentados por ETAPAS...................................

5.1.1 Filtros percoladores em escala piloto - ETAPA 01.......................67

5.1.1.1 Eficiência de molhamento dos meios suportes - ETAPA 01...69

5.1.1.2 Parâmetros de controle - ETAPA 01 69

5.1.1.3 Formas nitrogenadas - ETAPA 01 .72

5.1.1.4 DQO, DBO e SST - ETAPA 01 
5.1.2 Filtros percoladores em escala piloto - ETAPA 02.

5.1.2.1 Eficiência de molhamento dos meios suportes - ETAPA 02....81

5.1.2.2 Parâmetros de controle - ETAPA 02

5.1.2.3 Formas nitrogenadas - ETAPA 02. .84

5.1.2.4 DQO, DBO e SST - ETAPA 02 88

5.1.3 Filtros percoladores em escala piloto - ETAPA 03. .90

5.1.3.1 Eficiência de molhamento dos meios suportes - ETAPA 03...91

5.1.3.2 Parâmetros de controle - ETAPA 03 .92

5.1.3.3 Formas nitrogenadas - ETAPA 03. .95

5.1.3.4 DQO, DBO e SST - ETAPA 03. .99

5.1.4 Filtros percoladores em escala piloto - ETAPA 04. .101

5.1.4.1 Eficiência de molhamento dos meios suportes - ETAPA 04..103

5.1.4.2 Parâmetros de controle - ETAPA 04 104

5.1.4.3 Formas nitrogenadas - ETAPA 04. 107

5.1.4.4 DQO, DBO e SST - ETAPA 04

5.1 Comparação das etapas e discussão dos resultados. 113

6 CONCLUSÕES E RECOMENDAÇÕES. 125

7 REFERÊNCIAS BIBLIOGRÁFICAS 


\section{LISTA DE FIGURAS}

Figura 3.1: Transformações bioquímicas em Lagoas Anaeróbias............................................................................ 08

Figura 3.2: Transformações bioquímicas em Lagoas Facultativas. 11

Figura 3.3: Algas, energia luminosa e oxigênio em uma lagoa facultativa 13

Figura 3.4: Esquema da transformação do nitrogênio. .27

Figura 3.5: Relações entre amônia livre, ácido nitroso e nitrificadoras. 29

Figura 3.6: Seção típica de um Filtro

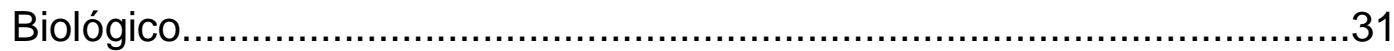

$\begin{array}{lllll}\text { Figura } & 3.7 & \text { Esquema de desenvolvimento de }\end{array}$ microorganismos. .32

Figura 3.8: Mecanismos e processos envolvidos na formação do biofilme. 34

Figura 3.9 : Resultados de um FBP preenchido por anéis plásticos .38

Figura 3.10 : Efeito do aumento da Taxa de aplicação superficial na eficiência de remoção de DBO solúvel. 39

Figura 3.11 - Principais Tipos de meio suporte normalmente utilizados em FBP. (A) Pedra Britada (B) Bloco Crossflow 60 (C) Bloco Crossflow 45, (D) Bloco Vertical Flow, (E) Anel Randômico ( $\varnothing$ 84mm) e (F) Anel Randômico ( $\varnothing$ 48mm). .44

Figura 3.12: Esquema do Processo PETRO............................................46

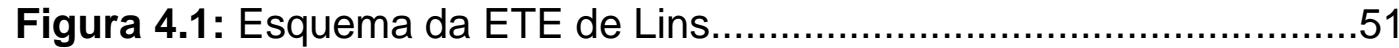

Figura 4.2: Foto aérea da ETE de Lins.............................................51

Figura 4.3: Fluxograma de todo processo.....................................54

Figura 4.4: Sistema de controle de vazão........................................55

Figura 4.5: Características do Distribuidor......................................57 
Figura 4.6: Distribuidor em funcionamento.....................................57

Figura 4.7: Vista geral do FBP.................................................58

Figura 4.8: Vista de cima do FBP ..............................................59

Figura 4.9: Detalhes construtivos do FBP.......................................60

Figura 4.10: Meios suporte.....................................................

Figura 4.11: Decantadores secundários do FBP .................................61

Figura 4.12: Detalhes construtivos dos decantadores.........................62

Figura 4.13: Corte esquemático dos FBPs.........................................65

Figura 5.1: Carga volumétrica de NKT - ETAPA 01...........................67

Figura 5.2: Taxa de aplicação hidráulica superficial nos filtros - ETAPA

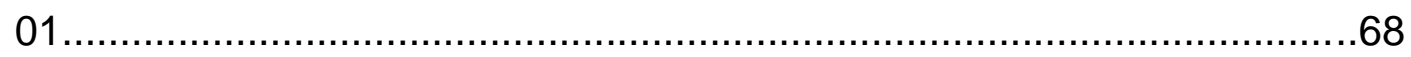

Figura 5.3: $\mathrm{pH}$ afluente e efluente dos filtros percoladores em escala piloto - ETAPA 01 .70

Figura 5.4: Temperatura afluente e efluente dos filtros percoladores em escala piloto - ETAPA 01. 70

Figura 5.5: Alcalinidade afluente e efluente dos filtros percoladores em escala piloto - ETAPA 01. .71

Figura 5.6: Concentração de oxigênio dissolvido afluente e efluente dos filtros percoladores em escala piloto - ETAPA 01. .72

Figura 5.7: Diagrama box-whisker e série histórica de nitrogênio amoniacal - ETAPA 01 .73

Figura 5.8: Características estatísticas da concentração de nitrogênio amoniacal dos filtros percoladores em escala piloto - ETAPA 01

Figura 5.9: Diagrama box-whisker e série histórica de nitrito - ETAPA 01. .75

Figura 5.10: Diagrama box-whisker e série histórica de nitrato - ETAPA 01 76

Figura 5.11: Gráfico de dispersão da concentração de DQO e DBO dos efluentes - ETAPA 01 .77 
Figura 5.12: Gráfico de dispersão da concentração de sólidos em

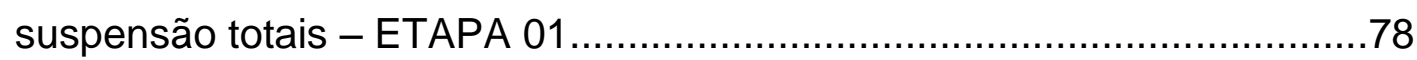

Figura 5.13: Carga volumétrica de NKT - ETAPA 02...........................79

Figura 5.14: Taxa de aplicação hidráulica superficial nos filtros - ETAPA 02.

Figura 5.15: $\mathrm{pH}$ afluente e efluente dos filtros percoladores em escala piloto - ETAPA 02. .82

Figura 5.16: Temperatura afluente e efluente dos filtros percoladores em escala piloto - ETAPA 02

Figura 5.17: Alcalinidade afluente e efluente dos filtros percoladores em escala piloto - ETAPA 02 83

Figura 5.18: Concentração de oxigênio dissolvido afluente e efluente dos filtros percoladores em escala piloto - ETAPA 02 .84

Figura 5.19: Diagrama box-whisker e série histórica de nitrogênio amoniacal - ETAPA 02

Figura 5.20: Características estatísticas da concentração de nitrogênio amoniacal dos filtros percoladores em escala piloto - ETAPA 02. 86

Figura 5.21: Diagrama box-whisker e série histórica de nitrito - ETAPA 02. .87

Figura 5.22: Diagrama box-whisker e série histórica de nitrato - ETAPA 02. 88

Figura 5.23: Concentrações de DQO e DBO dos efluentes - ETAPA 02 . .89

Figura 5.24: Gráfico de dispersão da concentração de sólidos em suspensão totais - ETAPA 02. .89

Figura 5.25: Carga volumétrica de NKT - ETAPA 03. .90

Figura 5.26: Taxa de aplicação hidráulica superficial nos filtros - ETAPA 03.

Figura 5.27: $\mathrm{pH}$ afluente e efluente dos filtros percoladores em escala piloto - ETAPA 03 .93

Figura 5.28: Temperatura afluente e efluente dos filtros percoladores em 
escala piloto - ETAPA 03 .93

Figura 5.29: Alcalinidade afluente e efluente dos filtros percoladores em escala piloto - ETAPA 03 94

Figura 5.30: Concentração de oxigênio dissolvido afluente e efluente dos filtros percoladores em escala piloto - ETAPA 03 95

Figura 5.31: Diagrama box-whisker e série histórica de nitrogênio amoniacal - ETAPA 03 .96

Figura 5.32: Características estatísticas da concentração de nitrogênio amoniacal dos filtros percoladores em escala piloto - ETAPA 03.

Figura 5.33: Diagrama box-whisker e série histórica de nitrito - ETAPA 03. 98

Figura 5.34: Diagrama box-whisker e série histórica de nitrato - ETAPA 03. 99

Figura 5.35: Concentrações de DQO e DBO dos efluentes - ETAPA 03. 100

Figura 5.36: Gráfico de dispersão da concentração de sólidos em suspensão totais - ETAPA 03 100

Figura 5.37: Carga volumétrica de NKT - ETAPA 04. 102

Figura 5.38: Taxa de aplicação hidráulica superficial nos filtros - ETAPA 04. 103

Figura 5.39: $\mathrm{pH}$ afluente e efluente dos filtros percoladores em escala piloto - ETAPA 04 105

Figura 5.40: Temperatura afluente e efluente dos filtros percoladores em escala piloto - ETAPA 04 105

Figura 5.41: Alcalinidade afluente e efluente dos filtros percoladores em escala piloto - ETAPA 04 106

Figura 5.42: Concentração de oxigênio dissolvido afluente e efluente dos filtros percoladores em escala piloto - ETAPA 04 107

Figura 5.43: Diagrama box-whisker e série histórica de nitrogênio amoniacal - ETAPA 04 108

Figura 5.44: Características estatísticas da concentração de nitrogênio 
amoniacal dos filtros percoladores em escala piloto - ETAPA 04. 108

Figura 5.45: Diagrama box-whisker e série histórica de nitrito - ETAPA 04 109

Figura 5.46: Diagrama box-whisker e série histórica de nitrato - ETAPA 04. 110

Figura 5.47: Concentrações de DQO e DBO dos efluentes - ETAPA 04.

Figura 5.48: Gráfico de dispersão da concentração de sólidos em suspensão totais - ETAPA 04

Figura 5.49: Box \& Whiskers das concentrações de $\mathrm{N}^{-\mathrm{NH}_{3}}$ afluentes e efluentes aos FBPs. 113

Figura 5.50: Box \& Whiskers das eficiências (\%) de remoção de $\mathrm{N}$ $\mathrm{NH}_{3}$

Figura 5.51: Box \& Whiskers das cargas superficiais de contato de $\mathrm{N}-\mathrm{NH}_{3}$ $\left(\mathrm{Kg} \mathrm{N}-\mathrm{NH}_{3} / \mathrm{m}^{2}\right.$.d) aplicadas aos FBPs 114

Figura 5.52: Série histórica das cargas superficiais de contato $\left(\mathrm{Kg} \mathrm{N}-\mathrm{NH}_{3}\right.$ $/ \mathrm{m}^{2}$.d) de acordo com a eficiência de remoção de $\mathrm{N}-\mathrm{NH}_{3}$ (\%) 116

Figura 5.53: Série histórica das taxas de aplicação hidráulica superficial $\left(\mathrm{m}^{3} / \mathrm{m}^{2}\right.$.d) de acordo com a eficiência de remoção de $\mathrm{N}$ $\mathrm{NH}_{3}(\%)$. 116

Figura 5.54: Série histórica das relações DBO: NTK de acordo com a eficiência de remoção de $\mathrm{N}-\mathrm{NH}_{3}(\%)$ 118

Figura 5.55: Box \& Whiskers das concentrações de $\mathrm{NO}_{2}^{-}$geradas nos FBPs

Figura 5.56: Box \& Whiskers das concentrações de $\mathrm{NO}_{3}{ }^{-}$geradas nos FBPs

Figura 5.57: Série histórica dos valores de $\mathrm{pH}$ de acordo com a eficiência de rem oção de $\mathrm{N}-\mathrm{NH}_{3}(\%)$.

Figura 5.58: Série histórica dos valores de alcalinidade de acordo com a eficiência de remoção de $\mathrm{N}-\mathrm{NH}_{3}(\%)$. .121 
Figura 5.59: Série histórica dos valores de alcalinidade de acordo com a eficiência de remoção de $\mathrm{N}-\mathrm{NH}_{3}(\%)$......................................122 Figura 5.60: Série histórica dos valores de Temperatura de acordo com a eficiência de remoção de $\mathrm{N}-\mathrm{NH}_{3}(\%)$ 123 Figura 5.61: Série histórica dos valores de OD de acordo com a eficiência de remoção de $\mathrm{N}-\mathrm{NH}_{3}(\%)$ 124 


\section{LISTA DE TABELAS}

Tabela 3.1: Principais parâmetros de projeto das lagoas anaeróbias.

Tabela 3.2: Principais parâmetros de projeto das lagoas facultativas.

Tabela 3.3: Resumo das principais tecnologias aplicadas no polimento do efluente de lagoas. 15

Tabela 3.4:Valores experimentais da Equação de Monod $(\mathrm{pH}=8$ e Temperatura $=20^{\circ} \mathrm{C}$ ) .22

Tabela 3.5: Características das quatro regiões principais do diagrama proposto por Anthonisen et al. (1978). 29

Tabela 3.6: Características típicas e classificação de filtros biológicos percoladores 35

Tabela 3.7: Classificação de filtros biológicos percoladores. .36

Tabela 3.8: Principais características e desempenhos de filtros biológicos percoladores em sistemas de tratamento de esgotos domésticos.

Tabela 3.9 : Principais características de material de enchimento

Tabela 3.10 - Processo PETRO operando com dois filtros percoladores em paralelo em Kanyamazane (Agosto, 1994)

Tabela 3.11- Resultados obtidos na entrada e saída do Biofiltro submerso.

Tabela 4.1: Dados de Projeto do Sistema de Lagoas de Estabilização de Lins/SP. Fonte: SABESP, 1997 . .52

Tabela 4.2: Condições operacionais aplicadas aos FBPs. .63

Tabela 4.3: Metodologias utilizadas para determinação de cada parâmetro 66

Tabela 5.1: Estatística descritiva dos valores medianos de DQO, DBO e SST - ETAPA 01 
Tabela 5.2: Estatística descritiva das medianas de DQO, DBO e SST -

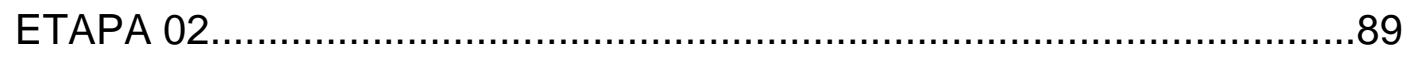

Tabela 5.3: Estatística descritiva dos valores das medianas de DQO, DBO e SST da ETAPA 03. 101

Tabela 5.4: Estatística descritiva dos valores das medianas de DQO, DBO e SST da ETAPA 04 .112

Tabela 5.5: Estatística descritiva da mediana dos valores da relação DBO: NTK. 


\section{LISTA DE ABREVIATURAS}

CETESB - Companhia de Tecnologia de Saneamento Ambiental

CONAMA - Conselho Nacional do Meio Ambiente

EPA - Environmental Protection Agency

ETE - Estação de Tratamento de Esgoto

LACI - Laboratório de Análises Químicas e Controle Industrial

OMS - Organização Mundial de Saúde

Poli-USP - Escola Politécnica da Universidade de São Paulo

SABESP - Companhia de Saneamento Básico do Estado de São Paulo

Unilins - Centro Universitário de Lins

USP - Universidade de São Paulo

PROSAB - Programa de Pesquisa em Saneamento Básico 


\section{LISTA DE SIMBOLOS}

${ }^{\circ} \mathrm{C}$ - Graus Celsius

$\mathrm{DBO}_{5,20}$ - Demanda Bioquímica de Oxigênio depois de 5 dias à temperatura de $20^{\circ} \mathrm{C}$

DQO - Demanda Química de Oxigênio

$\mathrm{H}_{2}-$ Gás Hidrogênio

$\mathrm{H}_{2} \mathrm{~S}-$ Gás Sulfídrico

$\mathrm{Kg} \mathrm{-} \mathrm{Kilograma}$

Lab - Laboratório

$\mathrm{m}$ - Metros

$\mathrm{N}_{2}-$ Gás Nitrogênio

$\mathrm{NaOH}$ - Hidróxido de Sódio

NTK - Nitrogênio Kjeldhal Total

$\mathrm{N}-\mathrm{NH}_{3}-$ Nitrogênio Amoniacal

$\mathrm{NO}_{2}^{-}$- Nitrito

$\mathrm{NO}_{3}^{-}-$Nitrato

$\mathrm{O}_{2}-$ Gás Oxigênio

pH - Potencial Hidrogeniônico

STF - Sólidos Totais Fixos

SSF - Sólidos Suspensos Fixos

SST - Sólidos Suspensos Total

SSV - Sólidos Suspensos Voláteis

ST - Sólidos Totais

STV - Sólidos Totais Voláteis

$\mathrm{T}$ - temperatura

TES - Taxa de escoamento superficial

TAV - Taxa de aplicação volumétrica

TAS - Taxa de aplicação superficial

Q - Vazão 


\section{INTRODUÇÃO}

No Brasil, diversas estações de tratamento de esgotos domésticos de pequeno porte utilizam as lagoas de estabilização como processo de tratamento, por ser uma alternativa de custo competitivo, ter uma simplicidade na construção e operação e também por ser bastante recomendada em regiões com grande disponibilidade de área e clima quente, o que favorece a implantação e o bom funcionamento do processo. Porém, a baixa eficiência com relação à remoção de nutrientes (nitrogênio e fósforo) e a presença de algas, que além de ser parte da fonte de matéria orgânica, também é fonte de nitrogênio e fósforo na forma orgânica, prejudicam a qualidade do efluente excedendo as concentrações máximas que devem ser mantidas nos corpos receptores.

O lançamento de nitrogênio amoniacal nos corpos lênticos receptores é bastante prejudicial, visto os diversos impactos negativos que pode causar:

- A presença de nitrogênio e fósforo são essenciais ao desenvolvimento de algas, ou seja, estas são dentre outras substâncias as responsáveis pela eutrofização das águas naturais;

- A amônia ao ser oxidada biologicamente consome oxigênio dissolvido, o que constitui Demanda Biológica de Oxigênio $\left(\mathrm{DBO}_{5}\right)$, libera íons $\mathrm{H}^{+}$e diminui o $\mathrm{pH}$ do corpo receptor;

- A amônia livre é um composto tóxico à vida aquática; isto inclusive em ambientes lóticos.

Portanto a escolha de tecnologias para o tratamento de esgotos deve levar em conta a capacidade do sistema de desempenhar a nitrificação.

A principal referência para esta discussão é a Resolução $\mathrm{N}^{0} 357$ do CONAMA, promulgada no ano de 2005 onde o padrão de emissão para 
nitrogênio amoniacal é de $20 \mathrm{mg} \mathrm{N}-\mathrm{NH}_{3} / \mathrm{L}$, que foi o principal motivador do desenvolvimento deste projeto de pesquisa.

A mesma sofreu uma alteração no Artigo 34 por meio da Resolução Nº 397 do CONAMA promulgada em 2008, e a partir da sua publicação ficou estabelecido que o padrão de emissão para nitrogênio amoniacal total será suspenso temporariamente para efluentes de estações de tratamento de esgoto sanitário, continuando a valer a concentração máxima nos corpos receptores estabelecidas no CONAMA 357, sendo assim a questão de não remoção de nutrientes constitui uma preocupação diretamente relacionada ao emprego dos sistemas de lagoas de estabilização.

Outro ponto importante se trata do padrão de classificação de águas naturais caracterizadas como ambientes lênticos, intermediários ou lóticos, onde as exigências ainda deverão resultar incompatíveis com o emprego de lagoas, em que a remoção deste constituinte é muito baixa. Em diversas regiões, a capacidade de diluição dos corpos receptores dos esgotos tratados é muito baixa e não é possível o atendimento aos limites definidos para o nitrogênio amoniacal total. Para que o efluente de lagoa de estabilização seja capaz de atingir valores baixos faz-se necessário o uso de um pós-tratamento.

De acordo com Hespanhol (2003), a aplicação de esgotos no solo é uma forma efetiva de controle da poluição e uma alternativa viável para aumentar a disponibilidade hídrica principalmente em regiões áridas e semi-áridas. Os maiores benefícios dessa forma de reúso, são os associados aos aspectos econômicos, ambientais e de saúde pública.

A SABESP opera cerca de 200 lagoas de estabilização no Interior do Estado de São Paulo, cuja vazão representa aproximadamente 3\% do total de água de irrigação previsto, e poderá irrigar em média 15.000 hectares (TSUTIYA, 2001). O uso desta tecnologia pode trazer alguns benefícios como a possibilidade de irrigação permanente que favorece o desenvolvimento das 
plantas, a adição de nutrientes (nitrogênio e fósforo) gerando uma economia na aplicação de fertilizantes, além de ser considerado um pós-tratamento deste tipo de efluente.

No entanto, o reúso agrícola do efluente de lagoas de estabilização apresenta alguns obstáculos como: a possível salinização do solo devido à presença de sódio e potássio no efluente, comprometendo sua porosidade; a contaminação do solo e ou da plantação pela presença de organismos patogênicos, substâncias tóxicas ou até mesmo de metais pesados; o entupimento das tubulações de irrigação devido à grande quantidade de sólidos (principalmente as algas) no efluente.

Portanto são muitos os obstáculos a serem superados. A legislação reguladora da aplicação de efluentes no solo é ainda iniciante no Brasil. Mesmo ocorrendo este disciplinamento e a garantia de que os efluentes dos sistemas de lagoas de estabilização apresentarão capacidade de atendê-lo, ainda há que se preocupar com o fato de que não será possível o uso agrícola de todo o esgoto tratado sem quebra de continuidade. Uma evidência disto é a ocorrência de altos índices pluviométricos em determinadas épocas do ano e a conseqüente impossibilidade de irrigação com esgoto. Nesta situação, ou em outras imagináveis como, épocas de plantio, colheita, entressafras etc., haverá necessidade de descarga em corpos d'água. O sistema deverá então estar preparado para tal devendo ser implantadas unidades para o tratamento complementar do esgoto.

Inspirado neste contexto, no Município de Lins/SP, um grupo de pesquisadores da USP estava envolvido com esta atividade no campo experimental de uso agrícola do efluente do sistema de lagoas de estabilização pertencente à SABESP; este trabalho foi realizado no âmbito do Edital 4 e 5 do PROSAB, particularmente este, no Edital 5, cujo desafio foi a necessidade de remoção de nitrogênio. 
Diversas pesquisas estudaram tecnologias de pós-tratamento de efluentes oriundas de lagoas de estabilização visando remoção de nitrogênio: lagoas complementares de baixa profundidade e filtros biológicos, e este projeto, particularmente, refere-se aos filtros biológicos do tipo percoladores.

Vale ressaltar que um sistema constituído de lagoas seguidas de filtros percoladores não parece uma alternativa viável para um projeto original, mas como existem inúmeros sistemas de lagoas no estado e nestes casos, a complementação com os filtros biológicos poderia ser viável.

A opção pelos filtros biológicos se baseou na qualidade do efluente final da lagoa facultativa, tendo OD alto e DBO solúvel baixa, o que nos permitiria a aplicação de taxas elevadas no filtro, o que não demandaria grandes áreas e em pequenos volumes de filtro se pretende alcançar a nitrificação esperada.

Neste sentido, este estudo procura avaliar a remoção de matéria orgânica e nitrogênio amoniacal em um filtro biológico percolador, preenchidos com dois materiais suporte diferentes pós-tratando o efluente de uma lagoa facultativa. Para tal, o FBP será submetido a diferentes fases operacionais, variando suas taxas de aplicação superficiais. 


\section{OBJETIVO}

\subsection{Objetivo Geral}

Avaliar a capacidade de nitrificação de filtros biológicos percoladores para o pós-tratamento de efluentes de lagoa facultativa.

\subsection{Objetivos específicos}

- Contribuir com parâmetros de funcionamento/ operação de Filtros Biológicos Percoladores testando efluentes de lagoas facultativas;

- Comparar a eficiência de dois filtros biológicos preenchidos com materiais suporte diferentes;

- Relacionar as taxas de aplicação superficiais aplicadas aos filtros com a eficiência de remoção de $\mathrm{N}-\mathrm{NH}_{3}$;

- $\quad$ Avaliar a remoção de Nitrogênio amoniacal;

- $\quad$ Avaliar a produção de nitrito e nitrato;

- Avaliar o desempenho de remoção de matéria orgânica;

- Utilizar o conceito de eficiência de molhamento;

- Avaliar a influência das cargas de aplicação superficiais, a relação DBO:NTK afluente e os parâmetros de controle como $\mathrm{pH}$, Temperatura, OD e alcalinidade interferem na eficiência de remoção de Nitrogênio amoniacal. 


\section{REVISÃO BIBLIOGRÁFICA}

\subsection{Lagoas de estabilização}

O sistema de lagoas de estabilização é um dos tipos de tratamento mais utilizado no Brasil, pela disponibilidade de área, clima favorável, custo competitivo de implantação e operação, simplicidade na construção, operação e manutenção, dentre outras vantagens. Porém o efluente das lagoas facultativas possui dificuldades em satisfazer os restritivos padrões de lançamento recomendados pela Resolução № 357 do CONAMA. Como principais desvantagens podem ser listadas a exigência de áreas relativamente grandes, a presença de elevadas concentrações de algas no efluente final, baixa eficiência na remoção de nutrientes e a exalação de maus odores das lagoas anaeróbias.

Dentre os sistemas de lagoas de estabilização existem algumas variantes:

- Lagoa facultativa;

- Lagoa facultativa aerada;

- Lagoa aerada de mistura completa seguida de lagoa de decantação;

- Lagoa anaeróbia seguida de lagoa facultativa.

O sistema australiano é um arranjo que pode ser utilizado entre os tipos de lagoas, constituído do tratamento preliminar, seguido de lagoas anaeróbias, facultativas e de maturação. No sistema que utiliza a lagoa facultativa primária, não se inclui lagoas anaeróbias, com isso o sistema ocupa maior área, mas evitam-se as possibilidades de exalação de maus odores das lagoas anaeróbias. 
O sistema de lagoas de estabilização estudado é composto por lagoa anaeróbia seguida de lagoa facultativa, esta combinação também é denominada por sistema australiano, e por este motivo, será descrito com mais detalhes.

\subsubsection{Lagoa anaeróbia}

As lagoas anaeróbias são escavações mais profundas, com altura útil variando entre 3 a 5 metros, retendo os esgotos durante 4 a 6 dias. Nestas condições, garante-se a anaerobiose, uma vez que a penetração de luz e a sobrevivência de algas só são possíveis e de forma bastante limitada apenas em estreita camada superficial. Por outro lado, a taxa de aplicação de matéria orgânica é forçada, provocando o rápido esgotamento do oxigênio que por ventura esteja presente nos esgotos afluentes. Para as condições de temperatura no Brasil, obtêm-se eficiências na remoção da $\mathrm{DBO}_{5}$ dos esgotos da ordem de 40 a $60 \%$.

Sob estas condições, a matéria orgânica é convertida primeiramente por bactérias facultativas a ácidos voláteis, como o ácido acético, e depois é definitivamente oxidada a metano e gás carbônico por bactérias estritamente anaeróbias. O nitrogênio orgânico é oxidado a nitrogênio amoniacal e o nitrato pode ser reduzido a nitrogênio molecular, $N_{2}$ gasoso. Os fosfatos orgânicos são oxidados a ortofosfatos. A geração de maus odores ocorre com a redução de sulfato a sulfeto, promovendo a liberação do gás sulfídrico, $\mathrm{H}_{2} \mathrm{~S}$. Na Figura 3.1 apresenta-se um esquema do funcionamento de uma lagoa anaeróbia. 


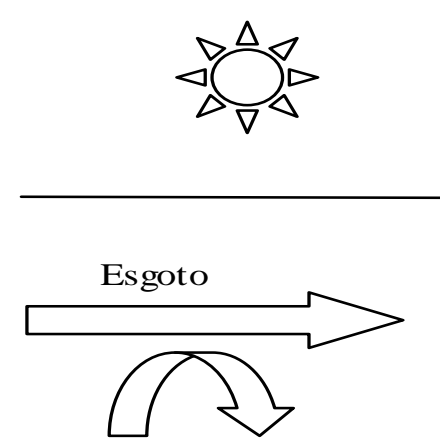

Sólidos

sedimentáveis

CHONPS $\longrightarrow$ Ácidos voláteis $\longrightarrow$ $\mathrm{CH}_{4}+\mathrm{CO}_{2}+\mathrm{H}_{2} \mathrm{O}$

N Orgânico $\longrightarrow$ N Amoniacal

$\mathrm{NO}_{3}^{-} \longrightarrow \mathrm{NO}_{2}^{-} \longrightarrow \mathrm{N}_{2}$

anaeróbia

Ausência

de $\mathrm{O}_{2}$

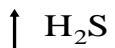

$\mathrm{SO}_{4}^{-2} \longrightarrow \mathrm{S}^{-2}\left(\mathrm{H}_{2} \mathrm{~S}\right)$

Lodo $\longrightarrow$ Ácidos orgânicos $\rightarrow \mathrm{CO}_{2}, \mathrm{NH}_{3}, \mathrm{H}_{2} \mathrm{~S}, \mathrm{CH}_{4}$

Figura 3.1: Transformações bioquímicas em Lagoas Anaeróbias.

Fonte: adaptado Von Sperling (2002)

Nos projetos, deve-se garantir a distribuição das entradas e das saídas dos esgotos, dificultando-se a ocorrência de caminhos preferenciais. O rebaixo adicional do fundo da lagoa até cerca de $1 / 4$ de seu comprimento resulta em um ganho de volume para acúmulo de lodo. A inclinação dos taludes a ser estabelecida depende dos estudos geotécnicos a serem feitos preliminarmente.

A lagoa anaeróbia precedendo uma lagoa facultativa tem como objetivo reduzir a carga orgânica do esgoto bruto a fim de diminuir a área requerida na lagoa facultativa.

A remoção de DBO na lagoa anaeróbia proporciona uma substancial economia de área para a lagoa facultativa, fazendo com que o requisito de área total (lagoa anaeróbia + lagoa facultativa) seja em torno de $45 \%$ a $70 \%$ do requisito de uma lagoa facultativa única (VON SPERLING, 2002).

Segundo Yánez (1993), as lagoas anaeróbias podem ser usadas como uma primeira etapa do tratamento de águas residuárias domésticas e industriais e 
apresentam uma série de vantagens e de desvantagens que devem ser consideradas antes de sua aplicação.

Dentre as vantagens das lagoas anaeróbias estão:

- $\quad$ Custo competitivo de implantação;

- As lagoas anaeróbias são recomendadas especialmente para o tratamento de efluentes de alta concentração de matéria orgânica;

- Têm sido implantadas com êxito no tratamento de uma grande variedade de efluentes industriais biodegradáveis.

Os aspectos desfavoráveis do uso de lagoas anaeróbias são:

- O processo é muito sensível a fatores ambientais e operacionais como: temperatura, variações bruscas de $\mathrm{pH}$, tendo como conseqüência um período de eficiência reduzida com um efluente de baixa qualidade;

- A acumulação de escuma na superfície da lagoa apresenta um aspecto desagradável;

- $\quad$ O efluente deste processo ainda possui uma grande quantidade de cor e matéria orgânica, tornando necessário um tratamento secundário;

- $\quad$ mau odor gerado neste processo, sobretudo nos primeiros anos de operação, com baixa carga, são indesejáveis à vizinhança, por isso este tipo de tratamento deve ser construído a uma distância considerável dos limites urbanos.

A Tabela 3.1 apresenta os principais parâmetros de projeto para uma lagoa anaeróbia. 
Tabela 3.1: Principais parâmetros de projeto das lagoas anaeróbias

\begin{tabular}{l|c}
\hline \multicolumn{1}{c|}{ PARÂMETROS } & FAIXA DE VARIAÇÃO \\
\hline Tempo de Detenção t(d) & 3 a 6 \\
\hline $\begin{array}{l}\text { Taxa de aplicação superficial Ls (kg } \\
\text { DBO/hab.d) }\end{array}$ & - \\
\hline Taxa de Aplicação Volumétrica Lv (kg \\
DBO/m³.d) \\
\hline Profundidade H (m) & 0,10 a 0,35 \\
\hline Relação L/B (comprimento/largura) usual & 1 a 3 \\
\hline Taxa de acumulo de lodo (m²/hab.ano) & 0,01 a 0,04 \\
\hline
\end{tabular}

Fonte: Adaptado de Von Sperling (2002)

\subsubsection{Lagoa facultativa}

As lagoas facultativas são escavações mais rasas, com profundidades típicas entre 1,5 a 2,0 m e áreas de espelho de água relativamente maiores do que as das anaeróbias. Os sólidos sedimentáveis presentes nos esgotos depositam-se no fundo das lagoas facultativas, entrando em decomposição anaeróbia. A matéria orgânica solúvel mantém-se na massa líquida, sofrendo decomposição aeróbia pela ação de microrganismos heterotróficos, que aproveitam o oxigênio liberado pela fotossíntese de algas. O gás carbônico resultante da decomposição da matéria orgânica é utilizado como matéria prima para o processo fotossintético, fechando o ciclo da simbiose que caracteriza o processo. Estas lagoas, em condições normais de operação, são capazes de propiciar eficiências na remoção de $\mathrm{DBO}_{5}$ superiores a $80 \%$.

A profundidade das lagoas facultativas permite a penetração de luz e a produção de oxigênio via fotossíntese em quase toda sua extensão, utilizada pelos microrganismos heterotróficos na decomposição de matéria orgânica. Parte dos sólidos dos esgotos sedimenta e entra em decomposição anaeróbia no fundo da lagoa, o que a torna facultativa. A ação de ventos sobre a superfície das lagoas também é importante para a oxigenação, o 
que torna desejável a manutenção de uma área livre em torno das lagoas. $\mathrm{Na}$ Figura 3.2 representam-se os principais mecanismos que ocorrem nas lagoas facultativas fotossintéticas.

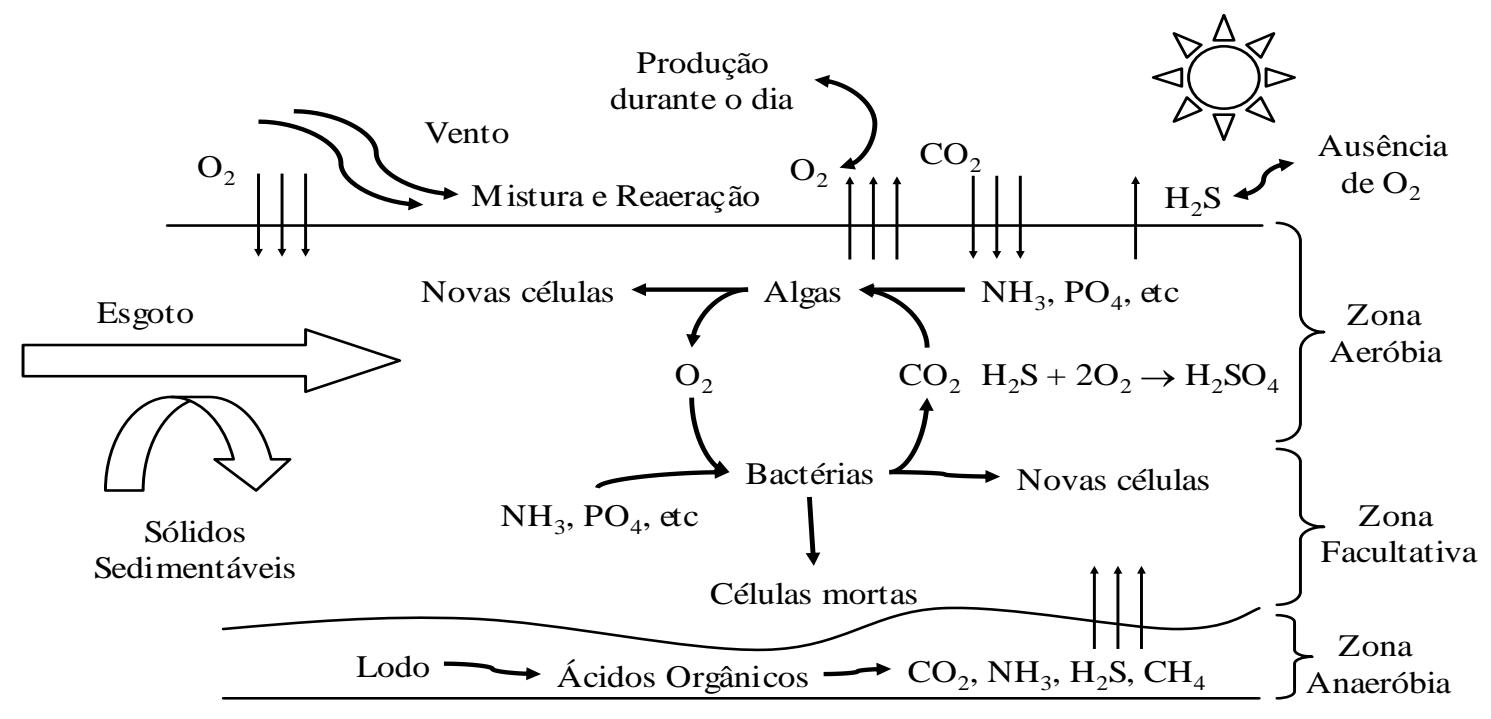

Figura 3.2: Transformações bioquímicas em Lagoas Facultativas.

Fonte: adaptado von Sperling (2002)

Muitas formulações são propostas na literatura para o dimensionamento de lagoas facultativas. Para climas tropicais, MARA apud JORDÃO E PESSOA (2005), desenvolveu uma adaptação da fórmula de Mac Garry e Pescod, sugerindo taxas de aplicação superficial específicas para lagoas facultativas primárias ou secundárias:

Taxa de aplicação superficial limite de DBO $\left(\lambda_{L}\right)$ para Lagoas Facultativas Primárias:

$\lambda_{L}=20 \times T-60$ Equação 3.1 
Onde: $\lambda_{L}$ - Taxa de aplicação limite de DBO para Lagoas Facultativas Primárias

T - Temperatura média do ar do mês mais frio do ano

Taxa de aplicação superficial limite de DBO $\left(\lambda_{\mathrm{L}}\right)$ para Lagoas Facultativas Secundárias:

$\lambda_{L}=14 \times T-42$

Equação 3.2

Onde: $\lambda_{L}$ - Taxa de aplicação limite de DBO para Lagoas Facultativas Secundárias

T - Temperatura média do ar do mês mais frio do ano

A profundidade típica das lagoas facultativas primárias é de 1,80 m, podendo-se acrescentar um rebaixo de $0,5 \mathrm{~m}$ no quarto inicial do comprimento para acúmulo de lodo, uma vez que neste arranjo não se incluem lagoas anaeróbias a montante. A relação comprimento/largura varia normalmente na faixa de $3 / 1$ a $5 / 1$, embora esses limites possam ser ultrapassados. A profundidade típica das lagoas facultativas secundárias é de $1,50 \mathrm{~m}$.

As algas necessitam de energia luminosa para o seu desenvolvimento, e é por este motivo que a maior quantidade de algas situa-se próximo à superfície da lagoa, ao longo da profundidade a intensidade luminosa diminui reduzindo assim a concentração de algas.

Segundo Von Sperling (2002), há um ponto ao longo da profundidade da lagoa em que a produção de oxigênio pelas algas se iguala ao consumo de oxigênio pelas próprias algas e pelos microrganismos decompositores. Este ponto é denominado de oxipausa (Figura 3.3). Acima da oxipausa predominam condições aeróbias, enquanto abaixo desta, predominam as condições anóxicas ou anaeróbias. O nível da oxipausa varia durante as 24 
horas do dia, em função da variabilidade da fotossíntese durante este período. À noite, a oxipausa se eleva na lagoa, ao passo que durante o dia ela se aprofunda. A profundidade da zona aeróbia, além de variar ao longo do dia, varia também com as condições de carga da lagoa. Lagoas com uma maior carga de DBO tendem a possuir uma maior camada anaeróbia, que pode ser praticamente total durante a noite.
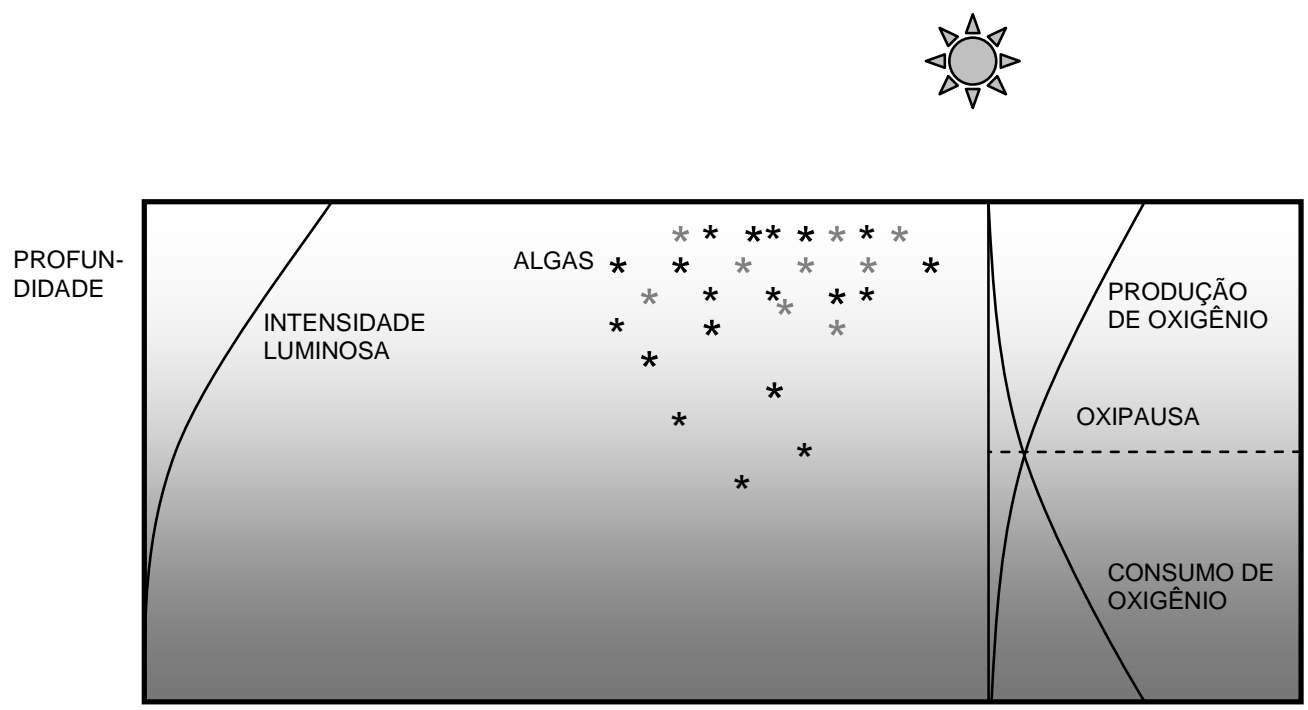

Figura 3.3: Algas, energia luminosa e oxigênio em uma lagoa facultativa (seção transversal).

Fonte: Adaptado de Von Sperling (2002)

A Tabela 3.2 apresenta os principais parâmetros de projeto para uma lagoa facultativa seguida de lagoa anaeróbia.

Tabela 3.2: Principais parâmetros de projeto das lagoas facultativas

\begin{tabular}{l|c}
\hline \multicolumn{1}{c|}{ PARÂMETROS } & FAIXA DE VARIAÇÃo \\
\hline Tempo de Detenção t(d) & 15 a 45 \\
\hline $\begin{array}{l}\text { Taxa de aplicação superficial Ls } \quad(\mathrm{kg} \\
\text { DBO/hab.d) }\end{array}$ & 100 a 350 \\
\hline Profundidade H (m) & 1,5 a 2,0 \\
\hline Relação L/B (comprimento/largura) usual & 2 a 4 \\
\hline Taxa de acúmulo de lodo (m³/hab.ano) & 0,03 a 0,08 \\
\hline
\end{tabular}

Fonte: Adaptado de Von Sperling (2002) 


\subsection{Pós-tratamento de efluentes de Lagoa de Estabilização}

O efluente de lagoas de estabilização apresenta elevada quantidade de algas e concentração alta de nutrientes.

Em estudos realizados na ETE de Lins, composta por lagoa anaeróbia seguida de lagoa facultativa, as principais preocupações foram com relação à presença de nutrientes e algas em concentração excessiva, Echerichia coli, bactérias patogênicas e ovos de Helmintos. Sob o ponto de vista químico, a carga orgânica residual de matéria orgânica biodegradável é ainda elevada, bem como a concentração de nitrogênio, na forma orgânica e amoniacal, o mesmo ocorrendo com as concentrações de fósforo total e ortofosfatos (PIVELI, PEREIRA, CUTOLO e ROCHA, 2003).

Para que este tipo de efluente se enquadre aos padrões estabelecidos, fazse necessário a utilização de tecnologias de pós-tratamento. A maioria destas tecnologias é composta de operações unitárias físicas e possuem diferentes custos e níveis de sofisticação.

Diversas tecnologias foram desenvolvidas e testadas no polimento final de efluentes de Lagoas Facultativas. Os processos mais conhecidos, tais como os filtros de pedra e as micropeneiras, visam justamente a remoção de algas. Recentemente, novos processos com capacidade de atingir também as formas solúveis de nitrogênio no efluente da lagoa vêm sendo testados (Middlebrooks, 1995; Meiring et al., 1995 e Oliveira e Gonçalves, 1999). Na Tabela 3.3 é apresentado um resumo das principais tecnologias aplicadas no polimento do efluente de lagoas. 
Tabela 3.3: Resumo das principais tecnologias aplicadas no polimento do efluente de lagoas

\begin{tabular}{|c|c|c|c|c|c|}
\hline \multirow{2}{*}{ TECNOLOGIAS } & & \multirow{2}{*}{$\frac{\text { TAXA APL. }}{\left(m^{3} / m^{2} . d\right)}$} & \multicolumn{3}{|c|}{ EFLUENTE (mg/l) } \\
\hline & & & SST & DBO & DQO \\
\hline Filtro de pedra submerso & Remove algas & 0,8 & 37 & 30 & - \\
\hline $\begin{array}{l}\text { Filtração intermitente em } \\
\text { areia }\end{array}$ & Remove algas & 0,37 & 25 & 21 & - \\
\hline Micropeneiras & Remove algas & 60 a 120 & $<30$ & $<30$ & - \\
\hline Microfiltração & $\begin{array}{l}\text { Remove } 100 \% \text { das } \\
\text { algas e S. faecalis }\end{array}$ & - & - & - & - \\
\hline Lagoa terciária (maturação) & Remove coliformes & - & 96 & - & 153 \\
\hline $\begin{array}{l}\text { Escoamento superficial em } \\
\text { Gramineas }\end{array}$ & $\begin{array}{lll}\begin{array}{l}\text { Remove algas } \\
\text { nitrifica }\end{array} & & \\
\end{array}$ & 0,013 & 5,5 & 3,5 & - \\
\hline Processo PETRO & $\begin{array}{l}\text { Remove algas } \mathrm{e} \\
\text { nitrifica }\end{array}$ & - & 23 & - & 96 \\
\hline Biofiltro aerado submerso & $\begin{array}{lll}\begin{array}{l}\text { Remove algas } \\
\text { nitrifica }\end{array} & & \\
\end{array}$ & 45,6 & 31 & - & 85 \\
\hline Processo físico-químico & $\begin{array}{lll}\text { Remove algas } & \mathrm{e} \\
\text { fósforo }\end{array}$ & 75 & 30,5 & - & 59 \\
\hline
\end{tabular}

Fonte: Oliveira e Gonçalves (1999)

Segundo Oliveira e Gonçalves (1999), com relação à remoção de organismos patogênicos as lagoas terciárias e a microfiltração apresentam os melhores resultados. Em função do estabelecimento de limites mais rigorosos para qualidade dos efluentes, incluindo os nutrientes $\mathrm{N}$ e $\mathrm{P}$ como alvo de restrição, se destaca o processo PETRO, bem como os Filtros Biológicos Aerados e os processos físico-químicos. No que se refere à remoção do nitrogênio, os filtros biológicos percoladores se destacam.

\subsection{Presença de algas no efluente de lagoas de estabilização}

As algas presentes nos sistemas de lagoas de estabilização têm como função a remoção de nutrientes, sendo o nitrogênio amoniacal o principal deles por ser empregado na síntese celular. De acordo com Dinges apud Mendonça (2001), o número de gêneros de algas de lagoas de estabilização é limitado. No geral, pertencem aos gêneros Phyla Cyanobacteria (algas verde azuladas, atualmente consideradas como bactérias: cianobactérias), 
Chlorophyta (algas verdes), Euglenophyta (os flagelados pigmentados) e Bacillariophyta (as diatoneas)

A presença de algas no efluente final é indesejável por fatores estéticos e por razões de saúde, pois algumas algas podem liberar substâncias tóxicas em determinadas circunstâncias. Sendo assim, para melhorar a qualidade do efluente, é necessária uma etapa de tratamento posterior às lagoas. (MONTEGGIA E TESSELE, 2001).

Segundo Reynolds e Richards (1996), aproximadamente um terço à metade do carbono orgânico afluente no esgoto bruto é sintetizado pelos microrganismos e algas que se desenvolvem nas lagoas facultativas. Tempos atrás, a $\mathrm{DBO}_{5}$ estabelecida era feita através de uma amostra do efluente filtrado, o que era um engano, pois as algas e microrganismos exerciam uma demanda de oxigênio no corpo receptor. A remoção de $\mathrm{DBO}_{5,20}$ de uma amostra filtrada do efluente seria de $80 \%$ a $90 \%$, enquanto a remoção de uma amostra não filtrada seria em torno de $45 \%$ a $60 \%$.

Baseando-se em resultados do monitoramento da ETE de Lins, na qual o esgoto bruto possui uma $\mathrm{DBO}_{5}$ de aproximadamente $350 \mathrm{mg} \mathrm{O} / \mathrm{L}$, com uma eficiência de $90 \%$ seria possível atingir um efluente com $35 \mathrm{mg} \mathrm{O}_{2} / \mathrm{L}$, enquanto que com uma eficiência de $60 \%$ a $\mathrm{DBO}_{5}$ do efluente seria de aproximadamente $140 \mathrm{mg} \mathrm{O} / \mathrm{L}$. Estes dados mostram a necessidade de remoção das algas para que o efluente se enquadre nos parâmetros estabelecidos pela legislação.

Usualmente costuma-se determinar a presença de algas indiretamente através da Clorofila A. Segundo Mara et al apud Von Sperling (2002), as concentrações de clorofila $A$ em lagoas de estabilização dependem da carga aplicada e da temperatura, mas usualmente situam na faixa de 500 a 2000 $\mu \mathrm{g} / \mathrm{L}$. 
Tendo como parâmetro de qualidade dos corpos d'agua, limites de Clorofila A estabelecido pela Resolução № 357 do CONAMA:

- $10 \mu \mathrm{g} / \mathrm{L}$ para águas doces de classe 1 ;

- $30 \mu \mathrm{g} / \mathrm{L}$ para águas doces de classe 2;

- $60 \mu \mathrm{g} / \mathrm{L}$ para águas doces de classe 3 .

Fica mais uma vez confirmada a necessidade de um pós-tratamento do efluente de lagoas de estabilização. Porém, a separação das algas apresenta algumas dificuldades (MONTEGGIA E TESSELE, 2001):

- Tamanho reduzido das algas (1 a $20 \mu \mathrm{m}$ );

- Baixa gravidade específica das células, reduzidas adicionalmente pela adesão de microbolhas de oxigênio produzido na respiração;

- A concentração relativamente diluída das suspensões contendo algas.

Alguns tipos de tratamento como: filtros de pedra, filtros intermitentes de areia, lagoas com macrófitas flutuantes, processos físico-químicos (sedimentação ou flotação), entre outros encontrados na literatura, são os mais recomendados para a remoção das algas em efluentes de lagoas de estabilização.

\subsection{Reúso agrícola do efluente de lagoas de estabilização}

O reúso agrícola de efluentes de lagoas de estabilização tem como vantagem a irrigação permanente, podendo contar ainda com a presença de nutrientes, como o nitrogênio e o fósforo.

Embora o nitrogênio possa agir como fertilizante, quantidades excessivas dos compostos deste elemento podem causar problemas às culturas agrícolas e animais (SAWYER et al, 1994). 
Segundo Ayers \& Westcot apud Athayde (2000) a forma de nitrogênio mais tóxica é o nitrito $\left(\mathrm{NO}_{2}{ }^{-}\right)$e as mais facilmente assimiláveis são o nitrato $\left(\mathrm{NO}_{3}{ }^{-}\right)$ e o íon amônio $\left(\mathrm{NH}_{4}{ }^{+}\right)$, sendo ainda o nitrogênio total de extrema importância devido às freqüentes transformações promovidas por bactérias sobre as várias formas de nitrogênio. Teores de nitrogênio total abaixo de $5 \mathrm{mg} / \mathrm{L}$ são tidos como não causadores de problemas, afetando muito pouco as culturas agrícolas mais sensíveis. Acima de $30 \mathrm{mg} / \mathrm{L}$ pode ser absorvido pelas plantas, sendo muito perigoso para algumas culturas.

Segundo Tsutiya (2001), a tecnologia mais adequada para o tratamento de esgotos para o uso agrícola, são as lagoas de estabilização. Porém a principal limitação do uso agrícola dos efluentes de ETEs, refere-se à qualidade microbiológica das águas residuárias, pois os esgotos sanitários podem veicular os mais variados microrganismos patogênicos, como os vírus, bactérias, protozoários e helmintos. Para o reuso agrícola é imprescindível que se obedeça às diretrizes microbiológicas, como o da Organização Mundial de Saúde.

De acordo com Yanéz (1993), devido à falta de investigação sobre organismos patogênicos em águas residuárias de países em desenvolvimento, a prática tradicional para projetar lagoas tem sido similar à de paises industrializados, baseada na redução de compostos orgânicos (DBO, DQO e nutrientes), com pouca ou nenhuma atenção aos aspectos de saúde pública. Esta prática convencional resulta em sistemas com células únicas. Uma revisão da prática moderna de projeto de lagoas indica que as novas concepções estão baseadas em múltiplos critérios, com a redução de compostos orgânicos, sólidos em suspensão, parasitas e coliformes fecais. Ao colocar em prática esta nova tendência, os projetos resultam em instalações com células múltiplas. 
Mas em se tratando de lagoas de estabilização já instaladas, em locais onde não haja espaço suficiente para a construção de lagoas de maturação, podese optar por processos de desinfecção por radiação UV, ozonização ou cloração a fim de melhorar a eficiência quanto à remoção de patógenos.

A desinfecção de efluentes de lagoas facultativas com hipoclorito de sódio demonstrou-se eficiente, não obstante a elevada concentração de sólidos em suspensão. Dosagens de cloro superiores a $7,0 \mathrm{mg} / \mathrm{L}$ foram necessárias para uma inativação eficiente de diversos organismos como coliformes, colifagos e Salmonella. A destruição de ovos de helmintos não foi eficiente. Não houve formação significativa de trihalometanos e ocorreu pequena redução adicional da DBO e DQO dos efluentes (PIVELI, PEREIRA E ROCHA, 2003).

Mas, existem outras preocupações quanto ao reuso agrícola de efluentes de lagoas de estabilização como o problema da salinização do solo devido ao manejo não adequado deste tipo de irrigação. Geralmente, os efluentes domésticos contem cerca de $190 \mathrm{mg} \mathrm{Na} / \mathrm{L}$ proveniente do uso elevado de sais, resultado dos hábitos alimentares da população e da utilização excessiva de determinados produtos de limpeza.

Segundo Mota (2005), a alta concentração de sais na água de irrigação desencadeia o processo de substituição dos íons cálcio e magnésio pelo íon sódio, causando a impermeabilidade do solo, impedindo a percolação da água. Apesar destas dificuldades, é possível a utilização de esgotos tratados em irrigação, desde que sejam adotados alguns cuidados:

- Escolha de culturas tolerantes aos sais;

- Escolha do método de irrigação adequado;

- Manejo adequado da água e do solo;

- Quantidade adequada de água aplicada;

- Drenagem da água aplicada; 
- Infiltração deve exceder a evaporação;

- $\quad$ Nos casos de salinização é necessária a correção do solo.

Resumidamente, quando se trata de reúso agrícola de efluente de lagoa de estabilização as maiores preocupações com relação à qualidade da água de irrigação são quanto à presença de organismos patogênicos e à salinidade. No entanto, em determinadas épocas, quando não há necessidade de irrigação, o efluente será lançado no corpo receptor, nestes casos, o mesmo deverá atender aos parâmetros de lançamento exigidos pela legislação.

\subsection{Fundamentos da Nitrificação Biológica}

O termo nitrificação é definido como sendo a oxidação biológica da Amônia $\left(\mathrm{N}-\mathrm{NH}_{3}\right.$, que se refere à concentração total de Nitrogênio Amoniacal, incluindo formas ionizadas e não ionizadas) para Nitrito $\left(\mathrm{NO}_{2}\right)$ e deste para Nitrato $\left(\mathrm{NO}_{3}\right)$. É um processo de duas etapas em sequencia, executado por dois tipos de bactérias autotróficas, obrigatoriamente aeróbias, que obtem sua energia através da oxidação de um substrato inorgânico, como a amônia, a formas mineralizadas.

A primeira etapa é a conversão de Amonia para Nitrito através da ação bioquímica de bactérias do gênero Nitrosomonas. A etapa seguinte, a oxidação do Nitrito para Nitrato é mediado por bactérias do gênero Nitrobacter. As reações estequiométricas referentes ao processo de oxidação da amônia a nitrato são:

Oxidação de $\mathrm{N}$-amoniacal pelas bactérias do genero Nitrosomonas:

$\mathrm{NH}_{4}^{+}+3 / 2 \mathrm{O}_{2} \rightarrow \mathrm{NO}_{2}^{-}+\mathrm{H}_{2} \mathrm{O}+2 \mathrm{H}^{+}$

Equação 3.3

Oxidação de Nitrito pelas bactérias do genero Nitrobacter:

$\mathrm{NO}_{2}^{-}+1 / 2 \mathrm{O}_{2} \rightarrow \mathrm{NO}_{3}^{-}$

Equação 3.4 
A equação global para a completa oxidação de amônia a nitrato:

$\mathrm{NH}_{4}^{+}+2 \mathrm{O}_{2} \rightarrow \mathrm{NO}_{3}^{-}+\mathrm{H}_{2} \mathrm{O}+2 \mathrm{H}^{+}$

Equação 3.5

De acordo com as estequiometria da equação global demonstrada, dois importantes aspectos que se referem ao processo de nitrificação biológica podem ser observados: o elevado consumo de oxigênio dissolvido para que o processo seja completamente efetuado (4,57 $\mathrm{g} \mathrm{O}_{2} / \mathrm{g} \mathrm{NH}_{4}{ }^{+}$oxidado a nitrato) e o significativo consumo de alcalinidade $\left(7,14 \mathrm{~g} \mathrm{CaCO}_{3} / \mathrm{g} \mathrm{NH}_{4}{ }^{+}\right.$ oxidada a nitrato); fato demarcado em virtude da produção de íons de hidrogênio associado ao processo de nitrificação.

Deve-se ressaltar que o uso de $\mathrm{NH}_{4}{ }^{+}-\mathrm{N}$ nas equações estequiométricas não significa que a principal fonte de energia para os microrganismos oxidadores de amônia seja o nitrogênio na forma de íon amônio. PAINTER (1986) cita, como hipótese, a possibilidade de que o principal substrato para microrganismos oxidadores de amônia seja a forma não ionizada do $\mathrm{N}$ amoniacal $\left(\mathrm{N}-\mathrm{NH}_{3}\right)$.

$\mathrm{Na}$ primeira etapa os microrganismos predominantes pertencem ao gênero de bactérias Nitrosomonas. Contudo, os gêneros Nitrossococus, Nitrosospira, Nitrosovibrio e Nitrosolobulus também podem oxidar Namoniacal a nitrito. Na segunda etapa o gênero comumente citado como sendo predominante é denominado Nitrobacter. No entanto, com o uso de técnicas de biologia molecular tem-se reportado que o gênero Nitrobacter parece não predominar em sistemas de tratamento dos esgotos. Considerase que o gênero Nitrospira é o gênero predominante entre as bactérias oxidadoras de nitrito (RITTMANN E MCCARTY, 2001; KOOPS e POMMERENINGRÖSER, 2001).

Outras considerações importantes que merecem comentário dizem respeito à cinética do processo de nitrificação. As taxas de crescimento e as taxas de 
remoção de substrato dos microorganismos nitrificantes podem ser descritas de acordo com as relações estabelecidas por Monod:

Taxa de crescimento dos microorganismos:

$\mathrm{dX} / \mathrm{dt}=\{(\mu$ máxSX $) /[(\mathrm{Ks}+\mathrm{S})]\}-\mathrm{Kd} \mathrm{X}$

Equação 3.6

Onde:

$\mathrm{dX} / \mathrm{dt}=$ Taxa de crescimento $\left(\mathrm{mg} \cdot \mathrm{I}^{-1} \cdot \mathrm{d}^{-1}\right.$.)

$\mu$ máx $=$ Taxa de crescimento específica máxima $\left(d^{-1}\right)$

$\mathrm{S}=$ Concentração do substrato ou nutriente limitante $(\mathrm{mg} / \mathrm{l})$

$X=$ Concentração de microorganismos $(\mathrm{mg} / \mathrm{l})$

$\mathrm{Ks}=$ Constante de saturação $(\mathrm{mg} / \mathrm{l})$

$\mathrm{Kd}=$ Coeficiente de respiração endógena $\left(\mathrm{d}^{-1}\right)$

Taxa de consumo de substrato:

$-\mathrm{dS} / \mathrm{dt}=(\mu \mathrm{máxSX}) /[\mathrm{Y}(\mathrm{Ks}+\mathrm{S})]$

Equação 3.7

Onde:

$\mathrm{dS} / \mathrm{dt}=$ Taxa de consumo de substrato $(\mathrm{mg} / \mathrm{l} / \mathrm{d}$. $)$

$\mu$ máx $=$ Taxa de crescimento específica máxima $\left(d^{-1}\right)$

$\mathrm{S}=$ Concentração do substrato ou nutriente limitante $(\mathrm{mg} / \mathrm{l})$

$\mathrm{X}=$ Concentração de microorganismos $(\mathrm{mg} / \mathrm{l})$

$\mathrm{Ks}=$ Constante de saturação $(\mathrm{mg} / \mathrm{l})$

$\mathrm{Y}=$ Coeficiente de produção celular

Tabela 3.4: Valores experimentais da Equação de Monod ( $\mathrm{pH}=8$ e $\left.\mathrm{T}=20^{\circ} \mathrm{C}\right)$

\begin{tabular}{|c|c|c|c|c|}
\hline Microorganismo & $\mu$ máx & $\mathrm{Y}$ & $\mathrm{Ks}$ & $\mathrm{KD}$ \\
\hline Nitrosomonas & $0,33-0,65\left(\mathrm{~d}^{-1}\right)$ & $0,147\left(\mathrm{~g} / \mathrm{gNH} 4^{+}-\mathrm{N}\right)$ & $0,73\left(\mathrm{mgNH} 4^{+}-\mathrm{N} / \mathrm{l}\right)$ & $0,048\left(\mathrm{~d}^{-1}\right)$ \\
\hline Heterotróficos & $1,2-6\left(\mathrm{~d}^{-1}\right)$ & $0,4 \mathrm{a} 0,8(\mathrm{~g} / \mathrm{gDBO})$ & $25-100(\mathrm{mg} \mathrm{DBO} / \mathrm{l})$ & $0,06-0,08\left(\mathrm{~d}^{-1}\right)$ \\
\hline
\end{tabular}

Fonte: adaptado de Ekama e Marais (1976) 
De acordo com os valores apresentados na literatura, o crescimento das Nitrosomonas é bastante lento comparados às heterotróficas, portanto em um sistema onde se objetiva a nitrificação, a Idade de lodo deve ser logicamente maior que a convencional.

O coeficiente de produção celular e as taxas de remoção de substrato parecem ser pouco influenciadas pelas taxas de $\mathrm{NH}_{4}{ }^{+}-\mathrm{N}$ presentes, visto que são valores bem reduzidos em comparação com os heterotróficos.

Outros fatores ambientais influenciam na taxa de crescimento das nitrificantes:

- Temperatura

Para um acréscimo de aproximadamente $7^{\circ} \mathrm{C}$ na temperatura, o valor de $\mu$ máx dobra e o inverso também é válido. $\mathrm{O}$ coeficiente de saturação Ks aumentam também com o acréscimo da temperatura. A temperatura ideal encontra-se na ordem de 25 a $36^{\circ} \mathrm{C}$ (Arceivala,1981).

- pH e Alcalinidade

Otimas taxas de nitrificação ocorrem em um faixa de $\mathrm{pH}$ de 7,5 a 8,0 (U.S. EPA, 1993). A taxa de nitrificação declina substancialmente para valores abaixo de 6,8 .

É importante ressaltar que a nitrificação é responsável pelo descrescimo de $\mathrm{pH}$, pois gera como produto final íons $\mathrm{H}^{+}$, e esse decréscimo depende da capacidade de tamponamento do meio, ou seja, da contribuição advinda da alcalinidade.

De acordo com Metcalf \& Eddy (2003) a alcalinidade residual mínima para nitrificação em sistemas com biofilmes: $>45 \mathrm{mg} / \mathrm{L}$ (observado) e 50 $\mathrm{mg} / \mathrm{L}$ (recomendado), já WEF (2006) recomenda que a alcalinidade seja mantida, no mínimo, numa faixa entre 50 e $100 \mathrm{mgCaCO}_{3} / \mathrm{l}$, a fim de evitar a diminuição do pH . A escassez de alcalinidade à carbonato no 
sistema impede a síntese de microrganismos nitrificantes por déficit de carbono inorgânico. Adicionalmente, a manutenção do $\mathrm{pH}$ em faixas adequadas para ocorrência de nitrificação pode ser comprometida.

- Oxigênio dissolvido

As taxas de nitrificação são afetadas de acordo com as concentrações de oxigênio dissolvido no reator biológico. Ao contrario do que se observa nas bactérias heterotróficas, a taxa de nitrificação aumenta acima de concentrações de OD de 3 a 4 mg/L.

Baixas concentrações de OD (menores que 0,5 mg/L), a taxa de crescimento das Nitrobacter são inibidas e portanto há um aumento de Nitrito no efluente (METCALF \& EDDY, 2003).

- Toxicidade ou Substancias inibidoras

As bactérias nitrificantes são boas indicadoras de compostos tóxicos no meio, mesmo que em pequenas quantidades, em muitos casos a taxa de nitrificação é inibida e em alguns, a toxicidade é responsável por inativa las.

Atualmente se conhece uma diversidade de substancias e produtos inibidores, porém um destaque importante se dá aos metais, é demostrado uma completa inibição da oxidação da amonia em concentrações de 0,25 mg/l de Niquel, 0,25 mg/l de Cromo e 0,10 mg/l de Cobre (METCALF \& EDDY, 2003).

\section{- Relação DBO:NTK}

Maiores relações DBO:NTK favorecem a predominância da biomassa heterotrófica no biofilme em virtude da maior taxa de crescimento específico e fluxo de síntese observado para esses microrganismos. Adicionalmente, a síntese da biomassa heterotrófica diminui a concentração de formas reduzidas de nitrogênio como a amônia. 
O aumento de microrganismos heterotróficos dificulta a transferência de substrato ( $\mathrm{N}$-amoniacal e $\mathrm{O}_{2}$ ), não sendo possivel a coexistência de microrganismos nitrificantes e heterotróficos no biofilme para elevadas relações DBO:NTK.

DBO:NTK = 25: pouca disponibilidade de formas reduzidas de nitrogênio para nitrificação;

DBO:NTK = 5 - 10: pode ser favorável ao processo de nitrificação, a depender das condições operacionais impostas.

\subsection{Desnitrificação Biológica}

A desnitrificação é a redução biológica de nitrato para formas reduzidas de nitrogênio, como $\mathrm{N}_{2}, \mathrm{~N}_{2} \mathrm{O}$ e $\mathrm{NO}$, isto é, nitrogênio gasoso. Os microorganismos responsáveis por este processo existem normalmente no esgoto doméstico, são facultativos heterotróficos, e requerem uma fonte de carbono orgânico disponível e ambiente anóxico.

A reação de desnitrificação é:

$\mathrm{C}_{5} \mathrm{H}_{7} \mathrm{NO}_{2}+4 \mathrm{NO}_{3} \rightarrow 5 \mathrm{CO}_{2}+2 \mathrm{~N}_{2}+\mathrm{NH}_{3}+4 \mathrm{OH}^{-} \quad$ Equação 3.8

É importante destacar que para que a desnitrificação aconteça é necessário que haja uma fonte de carbono orgânico disponível no efluente e também que haja $\mathrm{OD}<2 \mathrm{mg} / \mathrm{L}$ na zona onde ocorre a desnitrificação, portanto uma zona anóxica.

Baseado na estequiometria da reação da desnitrificação, a redução de 1 $\mathrm{mg} / \mathrm{L}$ de nitrogênio na forma de nitrato libera $2,86 \mathrm{mg} / \mathrm{L}$ de $\mathrm{O}_{2} / \mathrm{l}$, o que gera uma economia de oxigênio de aproximadamente $62 \%$. A mesma economia acontece com a alcalinidade, a redução de $1 \mathrm{~mol}$ de nitrato ocorre 
conjuntamente com o consumo de $1 \mathrm{~mol}$ de $\mathrm{H}^{+}$, ou seja um economia de $50 \%$ no consumo de alcalinidade.

\subsection{Acúmulo de Nitrito}

A remoção do nitrogênio em sistemas de lagoas facultativas para 0 tratamento de efluentes sanitários pode ocorrer, de acordo com Pano e Middlebrooks (1982) pela volatilização da forma não-ionizada do nitrogêno amoniacal sob condições favoráveis de temperatura e $\mathrm{pH}$, assimilação na biomassa algal e na nitrificação biológica pela transformação do nitrogênio amoniacal em nitritro e posteriormente em nitrato, sendo esta rota de remoção de nitrogênio considerada insignificante pelo próprio autor pela baixa concentração de nitrito e nitrato no efluente das lagoas. Esta baixa concentração ocorre pela indisponibilidade de oxigênio dissolvido no meio líquido, fator limitante para as bactérias nitrificantes e desnitrificantes.

Sensia et al. (2003) e Zimmo et al. (2004) apresentaram trabalhos indicando o processo de sedimentação do nitrogênio associado à biomassa como sendo a principal via de remoção de nitrogênio em lagoas fotossintéticas, sendo corroborado pelo trabalho apresentado por Ferrara e Avci (1982).

Apesar disto, diversos estudos entram em conflito sobre a rota de eliminação do nitrogênio do efluente tratado por lagoas, não se chegando a um concenso sobre a principal via de remoção do nitrogênio dos efluentes.

Outros estudo realizado com foco na remoção do nitrogênio via nitrificação se refere ao acúmulo de nitrito ocasionado pelo aumento da concentração de amônia e também pelo ácido nitroso no efluente quando em condições de baixo pH, conforme discussão apresentada por Anthonisen et al. (1976). Este acúmulo possui efeito inibidor sobre grupos de bactérias, principalmente as nitrossomas e nitrobacter, relacionadas com a transformação do nitrogênio amoniacal em nitrito e posteriormente em nitrato. 
A figura 3.4 abaixo representa suscintamente o efeito de nitrificação sem efeito cumulativo de nitrito (a) e com efeito cumulativo de nitrito no efluente (b).

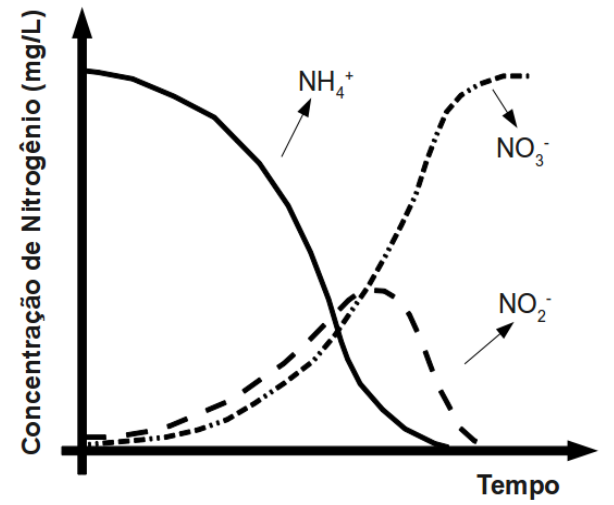

(a)

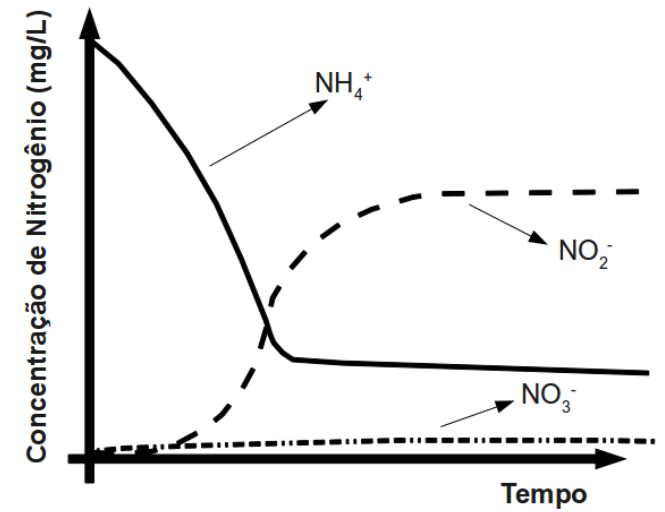

(b)

Figura 3.4: Esquema da transformação do nitrogênio - (a) sem inibição da nitrificação (b) com inibição, em um reator em batelada.

Adaptado: Anthonisen et al. (1976)

Isto ocorre, sengundo Anthonisen et al. (1976), porque determinadas concentrações de nitrogênio amoniacal podem inibir completamente o grupo de bactérias nitrossomas e nitrobacter, causando o acúmulo do próprio nitrogênio amoniacal. Quando em baixas concentrações, o nitrogênio amoniacal pode ter um efeito inibidor menor para as nitrossomonas do que para as nitrobacters, tendo como resultado o acúmulo de nitrito ao longo do tempo.

Além disso, a formação de ácido nitroso (baixo pH) ocasiona a inibição das bactérias nitrobacters principalmente, as quais realizam a oxidação do nitrito em nitrato, resultando no acúmulo de nitrito. Em contrapartida, o aumento do pH possibilita a oxidação da amônia para nitrato, reduzindo o seu efeito inibidor sobre as bactérias do grupo nitrobacter. A equação 3.9 apresenta a reação de equilíbrio para a formação do amônia livre $\left(\mathrm{NH}_{3}\right)$ : 


$$
\mathrm{NH}_{3}+\mathrm{H}^{+}<->\mathrm{NH}_{4}^{+} \quad \text { Equação } 3.9
$$

A amônia livre $\left(\mathrm{NH}_{3}\right)$ volatiliza, ao passo que amônia ionizada não pode ser removida por volatilização. Com a elevação do $\mathrm{pH}$, o equilíbrio da reação se desloca para a direita, favorecendo a maior presença de $\mathrm{NH}_{3}$. $\mathrm{No} \mathrm{pH}$ em torno da neutralidade, praticamente toda amônia encontra-se na forma de $\mathrm{NH}_{4}{ }^{+}$enquanto que valores de $\mathrm{pH}$ superiores a 11 apresentam praticamente toda amônia na forma de $\mathrm{NH}_{3}$, contribuindo dessa forma a remoção de nitrogênio.

Outro fator de inibição para a remoção do nitrogênio pela desnitrificação é a baixa concentração ou presença do oxigênio dissolvido em efluentes, essencial para a oxidação do nitrogênio.

A figura 3.5 apresenta um diagrama esquemático resumido com os fatores de inibição da nitrificação, a qual foi adaptada baseada nas informações apresentadas por Anthonisen et al. (1976) e, na tabela 3.5, estão apresentadas algumas características detalhadas sobre o diagrama. 


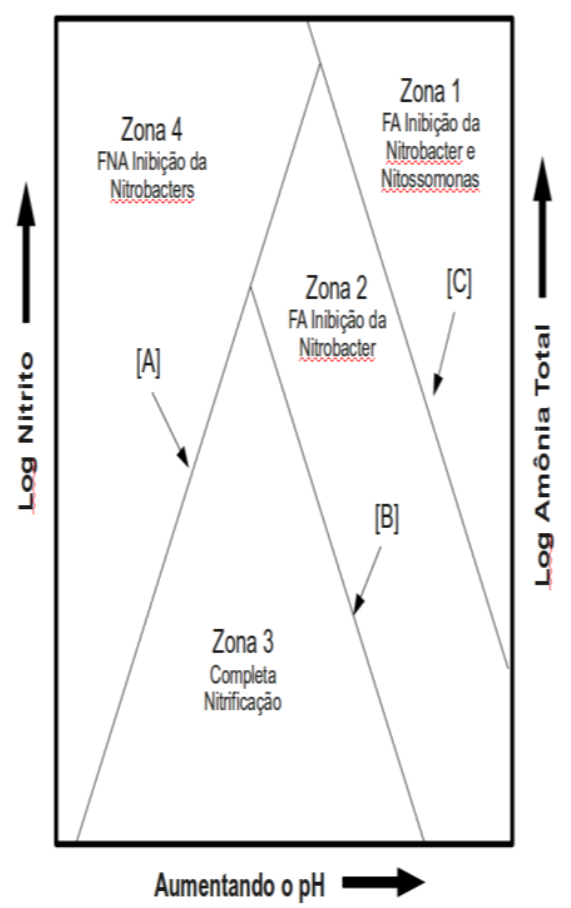

Figura 3.5: Relações entre amônia livre, ácido nitroso e nitrificadoras.

Adaptado: Anthonisen et al. (1976)

Tabela 3.5: Características das quatro regiões principais do diagrama proposto por Anthonisen et al. (1978)

\begin{tabular}{|c|c|}
\hline Região & Características \\
\hline Zona 1 & $\begin{array}{l}\text { - representa a condição quando a concentração de amônia livre é } \\
\text { alta o suficiente para inibir nitrossomonas e nitrobacters; } \\
\text { - não ocorrerá nitrificação e haverá acúmulo de nitrogênio amoniacal. }\end{array}$ \\
\hline Zona 2 & $\begin{array}{l}\text { - baixas concentrações de amônia livre (FA); } \\
\text { - inibição apenas das nitrobacters; } \\
\text { - acúmulo de nitrito. }\end{array}$ \\
\hline Zona 3 & $\begin{array}{l}\text { - baixas concentrações de FA; } \\
\text { - Não haverá inibição das nitrobacters e nitrossomonas; } \\
\text { - completa nitrificação. }\end{array}$ \\
\hline Zona 4 & - Nitrificação inibida devido a presença de ácido nitroso (FA). \\
\hline
\end{tabular}

Segundo PHILIPS et al. (2002), apesar dos estudos já publicados referentes a este assunto, o mecanismo de acúmulo de nitrito ainda não é claro. 


\subsection{Filtros Biológicos Percoladores}

\subsubsection{Aspectos gerais e princípios de funcionamento}

Os filtros biológicos percoladores já eram usados nos mais antigos processos de tratamento de águas residuais e têm sido pesquisados e melhorados (Imhoff e Gruhler, 1998). Mostraram ser eficientes e econômicos em países de clima temperado, tanto para degradar a matéria orgânica carbonácea como também para promover o processo de nitrificação.

Simplicidade de operação, baixo consumo energético, pouca necessidade de manutenção e longa vida tornam seu emprego bastante apropriado em países em desenvolvimento, nos quais soluções eficientes, confiáveis e sobretudo de baixo custo são desejadas.

Os reatores com biomassa aderida a um meio suporte garantem elevados tempos de retenção de sólidos, sem que para isso se faça necessário a recirculação do lodo. O filtro biológico aeróbio é um reator constituído essencialmente por um tanque com enchimento de pedras, plásticos ou outro tipo de material inerte, sobre o qual o despejo lançado na superfície percola por entre os interstícios do material que serve de suporte para os microorganismos. O lançamento do despejo é feito através de dispositivos de distribuição, fixos ou móveis, e a coleta ocorre através de um sistema de drenagem no fundo do filtro, permitindo uma condição de escoamento contínuo. A figura 3.6 ilustra a seção típica de um filtro biológico e seus componentes: 


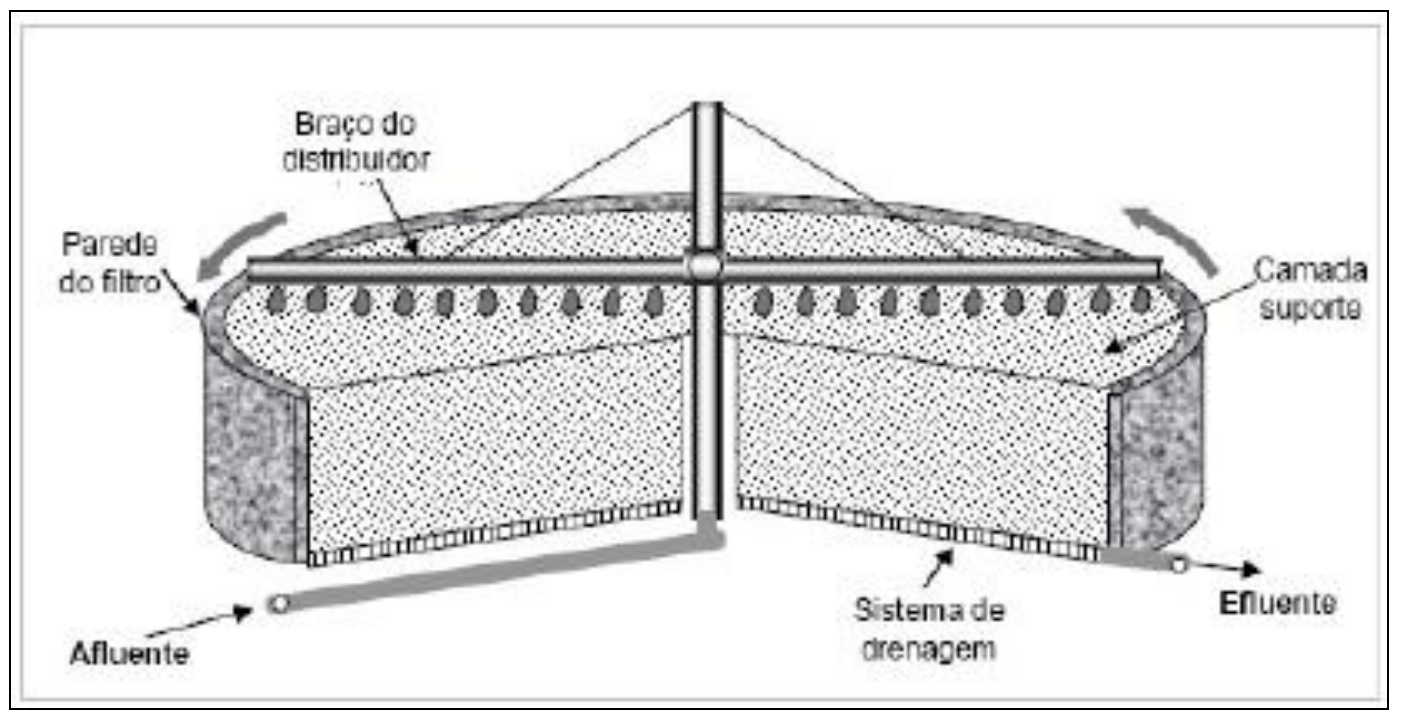

Figura 3.6: Seção típica de um Filtro Biológico

São sistemas aeróbios, o ar naturalmente circula nos espaços vazios do meio suporte, disponibilizando o oxigênio necessário para a respiração dos microorganismos sendo que a transferência de oxigênio para o biofilme é efetuada diretamente ou por meio de difusão molecular.

A percolação dos esgotos permite o crescimento bacteriano na superfície do material de enchimento (meio suporte), formando uma película ativa (biofilme), constituída por colônias gelatinosas de microrganismos (zooglea) de espessura máxima de 2 a $3 \mathrm{~mm}$ (METCALF \& EDDY, 2003). A matéria orgânica e inorgânica é adsorvida pela película microbiana, ficando retida um tempo suficiente para a sua estabilização.

Em seguida, parte do biofilme excedente é desprendido, podendo elevar a concentração de sólidos suspensos no efluente final. Este efeito ocorre devido a uma conjugação de fatores como tensão de cisalhamento causada pela velocidade de escoamento do liquido entre os vazios do meio suporte, grau de estabilização dos sólidos e relação crescimento da espessura do biofilme e geração de zonas inativas (MELO, 2003). O esquema de desenvolvimento dos microorganismos estão demonstrados na Figura 3.7: 


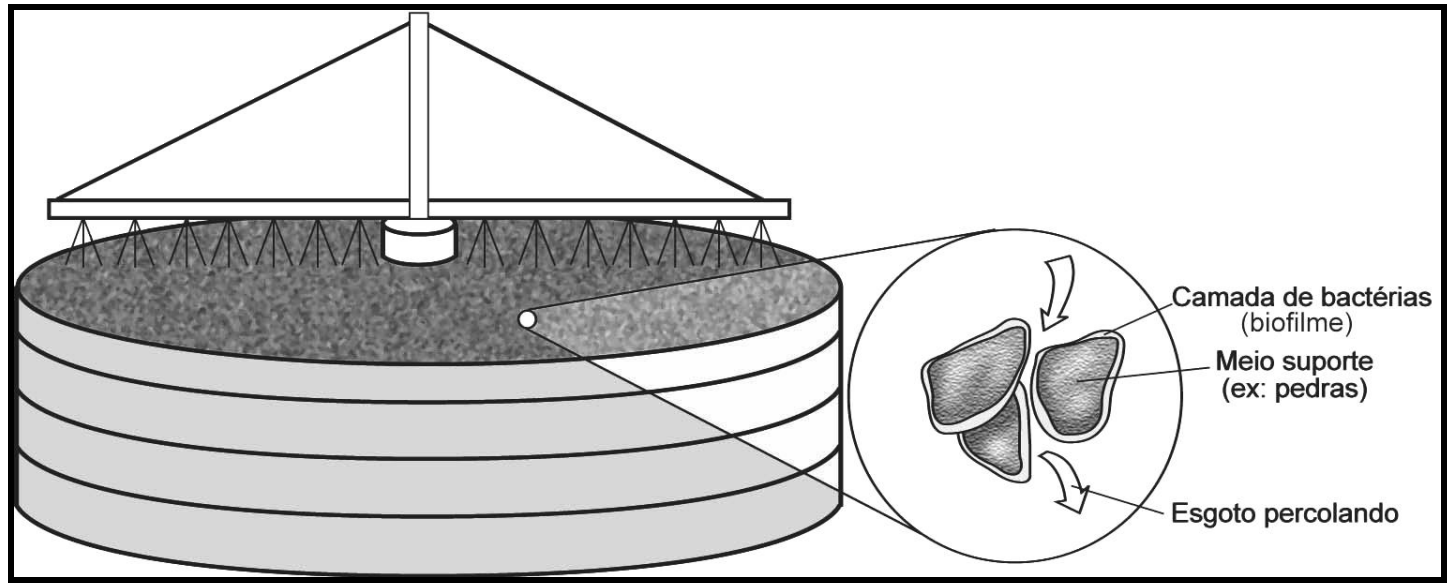

Figura 3.7 : Esquema de desenvolvimento de microorganismos

Em freqüentes situações, principalmente para filtros biológicos percoladores de alta taxa, é necessário o uso de decantadores secundários. Tais unidades são utilizadas no sentido de promover a separação dos sólidos, de forma que se possa obter um efluente final clarificado e com baixas concentrações de sólidos em suspensão.

\subsubsection{Aspectos gerais sobre a formação do biofilme em meio suporte}

A adesão microbiana em superfícies de contato segue três processos básicos: adsorção, adesão e aderência (estabilização da adesão celular), onde os mecanismos de fixação e estabelecimento do biofilme dependem fortemente da comunidade microbiana, das atividades metabólicas e do tipo de superfície disponível para o desenvolvimento da colonização.

Consolidada a adesão microbiana (primeira etapa do processo de formação de matrizes heterogêneas sob superfícies de contato), os microrganismos se reproduzem e produzem substâncias poliméricas extracelulares (freqüentemente compostas por polissacarídeos e glicoproteínas) formando uma matriz gelatinosa heterogênea denominada biofilme (LESSARD e LE BIHAN, 2003). O biofilme é constituído por cerca de $90 \%$ de água e as 
substâncias poliméricas extracelulares representam cerca de $50 \%$ no total de percentagem de massa (MELO, 2003).

Para o início de formação do biofilme, destaca-se um aspecto de grande importância: Superfícies de contato irregulares, porosas ou providas de interstícios são meios potenciais para o desenvolvimento inicial do biofilme. Ademais, uma maior área superficial de aderência parece estimular a produção de exopolímeros, desencadeando um aumento da excreção de polissacarídeos por parte dos microrganismos (VANVIVERE E KIRCHMAN, 1993 apud ALMEIDA, 2008).

A estrutura interna de biofilmes é composta por aglomerados contendo células, polímeros extracelulares que preenchem os espaços entre os aglomerados de microrganismos, canais e poros preenchidos por líquidos. De acordo com GONÇALVES et al. (2001), o processo metabólico de conversão sempre ocorre no interior do biofilme e o transporte do substrato orgânico se realiza por meio de processo de difusão, inicialmente na interface líquido/biofilme e, em seguida, no próprio biofilme.

Os subprodutos provenientes das reações de oxiredução são transportados no sentido inverso, da camada mais interna (anaeróbia) para a camada mais externa (aeróbia) do biofilme. A Figura 3.8 ilustra os mecanismos e processos envolvidos na formação do biofilme. 


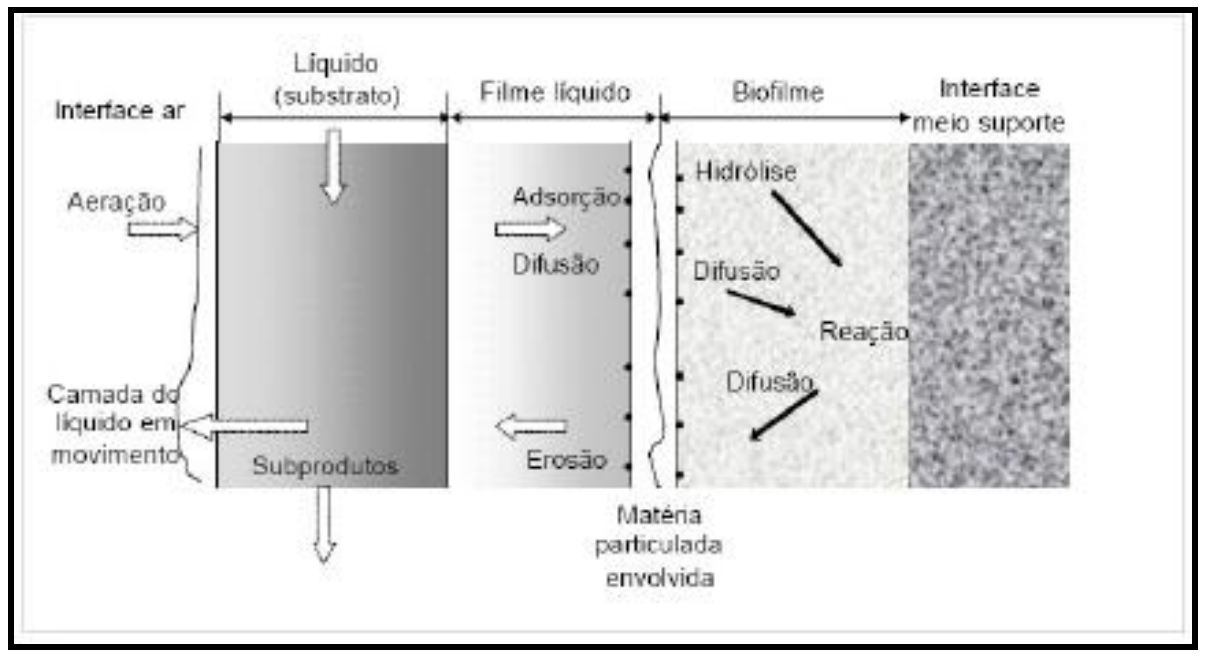

Figura 3.8: Mecanismos e processos envolvidos na formação do biofilme

Adicionalmente, destaca-se que os eventos de perda de biofilme são em geral causados por cizalhamento, abrasão e destacamento completo de parte da matriz gelatinosa formada. No entanto, em biofilmes contendo consórcios de bactérias nitrificantes e desnitrificantes os gases resultantes da redução do nitrato a nitrogênio gasoso podem promover a desagregação de parte da estrutura da biomassa em função de bolhas geradas no interior do biofilme (MELO, 2003).

\subsubsection{Classificação dos Filtros Biológicos}

Os filtros biológicos percoladores são classificados de acordo com a taxa de aplicação superficial (TAS) e a carga orgânica volumétrica, também conhecida como taxa de aplicação orgânica volumétrica (TAV). A TAS pode ser definida como a relação da vazão de esgoto aplicado e a área superficial útil do reator. Ja a carga orgânica volumétrica pode ser definida como a relação entre a massa de DBO contida no afluente ao FBP e o volume do meio suporte.

A tabela 3.6 apresenta as características de classificação dos filtros biológicos. 
Tabela 3.6: Características típicas e classificação de filtros biológicos percoladores

\begin{tabular}{|c|c|c|c|c|c|c|}
\hline \multicolumn{7}{|c|}{ Características típicas e classificação de filtros biológicos percoladores. } \\
\hline $\begin{array}{l}\text { Condiçōes } \\
\text { operacionais e } \\
\text { caracerísticas }\end{array}$ & $\begin{array}{l}\text { Baixa } \\
\text { taxa }\end{array}$ & $\begin{array}{c}\text { Taxa } \\
\text { intermediária }\end{array}$ & Alta taxa & Alta taxa & $\begin{array}{l}\text { Taxa super } \\
\text { alta }\end{array}$ & Grosseiro \\
\hline Meio suporte & Pedra & Pedra & Pedra & Plástico & Pedra & Pedra/plást. \\
\hline $\operatorname{TAS}^{1}\left(m^{3} / m^{2}, d\right)$ & $1-4$ & $4-10$ & $10-40$ & $10-75$ & $12-70$ & $40-200$ \\
\hline $\mathrm{COV}^{2}\left(\mathrm{kgDBO} / \mathrm{m}^{3} \cdot \mathrm{d}\right)$ & $0,07-0,22$ & $0,24-0,48$ & $0,4-2,4$ & $0,6-3,2$ & $0,5-1,6$ & $>1,5$ \\
\hline Recirculaçăo & 0 & $0-1$ & $1-2$ & $1-2$ & $\mathrm{NI}^{3}$ & $0-2$ \\
\hline Moscas & Muitas & Variável & Poucas & Poucas & Poucas & Poucas \\
\hline $\begin{array}{l}\text { Desprendimento do } \\
\text { biofilme }\end{array}$ & Intermitente & Intemitente & Contínuo & Contínuo & Contínuo & Contínuo \\
\hline Profundidade (m) & $1,8-2,5$ & $1,8-2,5$ & $0,9-3,0$ & $3,0-12,2$ & $3,0-12,2$ & $0,9-6,0$ \\
\hline $\begin{array}{l}\text { Remoçăo DBO (\%) } \\
\text { efluente de decantador } \\
\text { primário }\end{array}$ & $80-90$ & $50-80$ & $50-90$ & $60-90$ & $65-85$ & $40-70$ \\
\hline $\begin{array}{l}\text { Remoçăo DBO }(\%)^{3} \\
\text { efluente UASB }\end{array}$ & 55 & - & $45-65$ & - & - & - \\
\hline Remoçăo $\mathrm{NH}_{4}-\mathrm{N}$ & Intensa & Parcial & Parcial & Variável & Limitada & Ausente \\
\hline
\end{tabular}

Embora filtros biológicos percoladores de alta taxa preenchidos com leito de pedras possam receber cargas orgânicas volumétricas de até 2,4 $\mathrm{kgDBO} / \mathrm{m}^{3}$.d recomenda-se que as cargas orgânicas aplicadas estejam situadas entre 0,3 a $1,0 \mathrm{kgDBO} / \mathrm{m}^{3}$.d. A justificativa para a restrição da faixa de trabalho baseia-se na possibilidade de entupimentos mais freqüentes, curtos circuitos e limitação da circulação de ar e transferência de oxigênio para o interior do FBP, caso sejam adotadas maiores COVs (METCALF \& EDDY, 2003).

Na Tabela 3.7 são apresentadas as faixas adotadas para classificação de filtros biológicos percoladores e observa-se que diferem dependendo da referência consultada. 
Tabela 3.7: Classificação de filtros biológicos percoladores

\begin{tabular}{|c|c|c|c|c|c|}
\hline $\begin{aligned} \text { Classif } \\
\text { aplicadas de }\end{aligned}$ & $\begin{array}{l}\text { ação de filtro } \\
\text { ordo com alc }\end{array}$ & $\begin{array}{l}\text { biológicos per } \\
\text { umas referênci }\end{array}$ & oladores a & $\begin{array}{l}\text { artir de TAS } \\
\text { s na literatur }\end{array}$ & COVs \\
\hline \multirow{2}{*}{ Referência } & \multicolumn{5}{|c|}{$\begin{array}{l}\text { Taxa de aplicação superficial }\left(\mathrm{m}^{3} / \mathrm{m}^{2} . \mathrm{d}\right) \\
\text { Carga orgânica volumétrica aplicada }\left(\mathrm{kgDBO} / \mathrm{m}^{3} . \mathrm{d}\right)\end{array}$} \\
\hline & $\begin{array}{c}\text { Baixa } \\
\text { taxa }\end{array}$ & $\begin{array}{c}\text { Taxa } \\
\text { intermediária } \\
\end{array}$ & $\begin{array}{l}\text { Alta } \\
\text { taxa }\end{array}$ & $\begin{array}{l}\text { Taxa super } \\
\text { alta }\end{array}$ & Grosseiro \\
\hline \multirow{2}{*}{ Metcalf \& Eddy ${ }^{1}(2003)$} & $1-4$ & $4-10$ & $10-40$ & - & $40-200$ \\
\hline & $0,07-0,22$ & $0,24-0,48$ & $0,4-2,4$ & $0,6-3,2$ & $>1,5$ \\
\hline \multirow{2}{*}{ Metcalf \& Eddy (1991) } & $1-4$ & $3,5-10,0$ & $10-40$ & $12-70$ & $45-185$ \\
\hline & $0,1-0,4$ & $0,2-0,5$ & $0,5-1,0$ & $0,5-1,6$ & $\leq 8$ \\
\hline \multirow{2}{*}{$\mathrm{WEF}^{2}$ (1992) } & $1-3,6$ & $3,6-9,4$ & $\overline{9,4-36,6}$ & $14,2-85,5$ & $57-170$ \\
\hline & $0,1-0,2$ & $0,3-0,5$ & $0,4-1,8$ & $\leq 4,8$ & $>1,6$ \\
\hline \multirow{2}{*}{$\operatorname{WEF}^{3}(2000)$} & - & - & - & - & - \\
\hline & $<0,4$ & acima de 0,64 & $0,64-1,6$ & - & $1,6-4,8$ \\
\hline
\end{tabular}

3.8.4. Parâmetros de projeto que interferem na nitrificação em FBPs

Os parâmetros de projeto que afetam diretamente o processo de nitrificação são a carga orgânica volumétrica aplicada e a taxa de aplicação superficial.

- Carga orgânica volumétrica aplicada

Para uma eficiência de $90 \%$ na remoção de $\mathrm{N}^{-N_{4}}{ }^{+}$, a carga orgânica volumétrica aplicada deve ser aproximadamente de 0,08 $\mathrm{kgDBO} / \mathrm{m}^{3} . \mathrm{d}$. Em sistemas com cargas orgânicas volumétricas aplicadas de $0,22 \mathrm{kgDBO} / \mathrm{m}^{3} . \mathrm{d}$ é esperada uma eficiência de $50 \%$ na remoção de nitrogênio amoniacal (METCALF \& EDDY, 2003).

Parker \& Richards (1986) afirmam que para FBPs com leito de pedras (sem recirculação) a carga orgânica volumétrica não deve exceder a 0,16 $\mathrm{kgDBO} / \mathrm{m}^{3}$.d para uma eficiência de remoção de amônia de $75 \%$. No 
entanto, Stenquist (1974) obteve $89 \%$ de remoção de Namoniacal aplicando uma carga orgânica volumétrica de $0,36 \mathrm{kgDBO} / \mathrm{m}^{3} . \mathrm{d}$ em filtros biológicos percoladores com meios plásticos como material de enchimento. Portanto, as expectativas de remoção de $\mathrm{N}$-amoniacal em FBPs devem ser vistas com ressalvas tendo em vista que outros fatores associados à concepção de projeto podem influenciar na eficiência de remoção de $\mathrm{N}$-amoniacal em FBPs, como a altura do volume reacional, área superficial específica do material de enchimento utilizado e o tempo de detenção do líquido no reator.

Metcalf \& Eddy (2003) propõem utilização de $0,1-0,3 \mathrm{kgDBO} / \mathrm{m}^{3} . \mathrm{d}$ e de $0,2-$ 1,0 $\mathrm{gNTK} / \mathrm{m}^{2} \cdot \mathrm{d}^{1}$, portanto faixas típicas de cargas orgânicas e de NTK aplicadas, considerando sistemas de remoção combinada de matéria orgânica e nitrogênio amoniacal.

O decaimento da eficiência na remoção de amônia em filtros biológicos percoladores ocorre em virtude das cargas orgânicas volumétricas aplicadas serem dependentes das concentrações afluentes de matéria orgânica. Caso as concentrações afluentes de DBO se elevem, a relação DBO:NTK pode aumentar ocasionando a redução das taxas de nitrificação. WEF (2000) apresenta um modelo do efeito da relação DBO:NTK na nitrificação, considerando a remoção de $\mathrm{N}$-amoniacal por área de material suporte. $\mathrm{A}$ Figura 3.9 mostra os resultados obtidos para um FBP preenchido por anéis plásticos.

PARKER \& RICHARDS (1986) determinam similarmente o percentual de remoção de amônia em filtros biológicos percoladores considerando a carga orgânica aplicada por área de meio suporte. A partir desse critério, o efeito de cargas aplicadas (em termos de DBO ou NTK) pode ser melhor verificado uma vez que a avaliação das taxas de nitrificação por área de meio suporte não considera a influência do tipo de material de enchimento. 


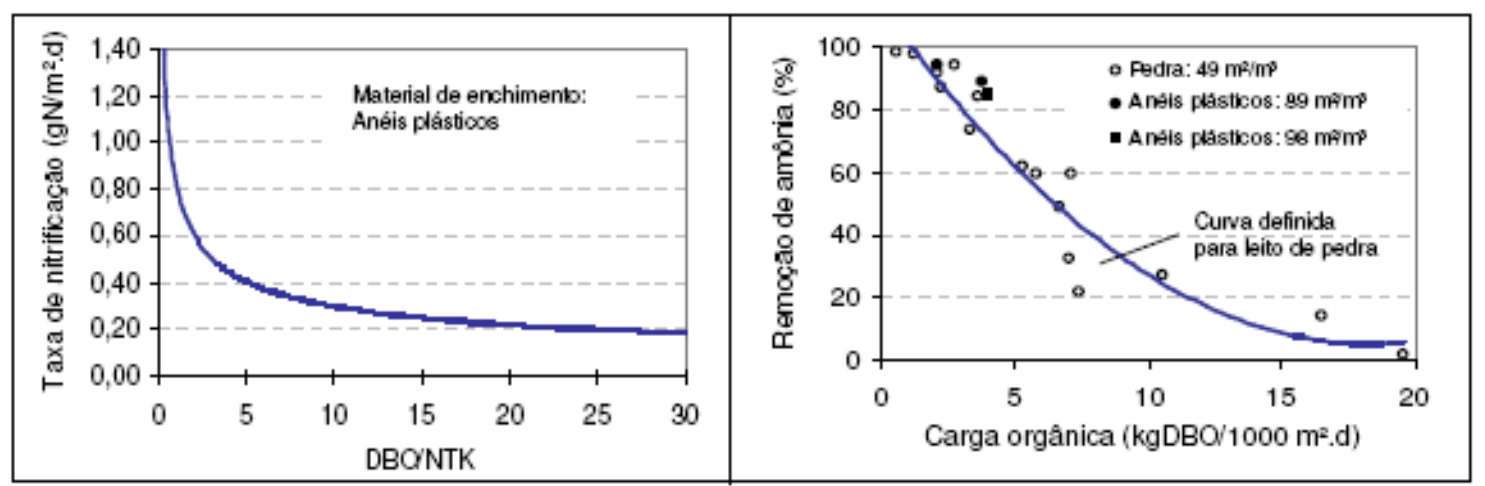

Figura 3.9 : Resultados de um FBP preenchido por anéis plásticos

- Taxa de aplicação superficial

Caso a taxa de aplicação superficial seja aumentada em função da vazão afluente (sem recirculação) a remoção de nitrogênio amoniacal e de matéria orgânica pode reduzir-se em função deste aumento.

Grady \& Lim (1980) destacam que com o aumento da taxa de aplicação superficial as relações DBO:NTK ao longo do perfil do filtro se reduzem, tendo em vista que o aumento nas taxas de reação para remoção de matéria orgânica, em qualquer ponto do FBP, não é suficiente para compensar o decréscimo do tempo de residência do líquido no reator. A Figura 3.10 mostra o efeito do aumento da taxa de aplicação superficial na eficiência de remoção de DBO solúvel segundo o modelo desenvolvido por Logan et al (1987) e de $\mathrm{N}$-amoniacal, de acordo com os experimentos de Raj \& Murthy (1998). 


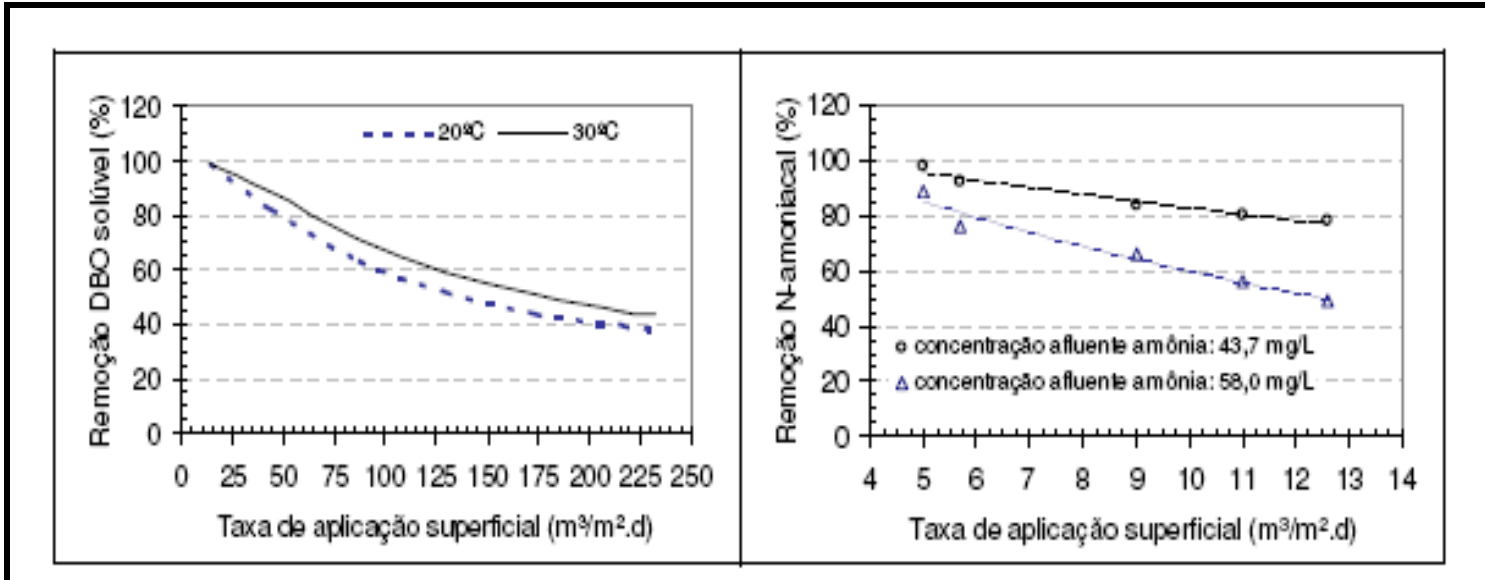

Figura 3.10 : Efeito do aumento da Taxa de aplicação superficial na eficiência de remoção de DBO soluvel

A apresentação dos resultados descritos mostra que, para uma determinada concentração efluente de DBO e N-amoniacal, o aumento da taxa de aplicação superficial resulta no decréscimo da eficiência de remoção dos referidos constituintes evidenciando a possibilidade de aumento das relações DBO:NTK ao longo do FBP.

Além deste fato, de acordo com algumas fontes (WEF,2000; PARKER et al.,1997; CRINE et al., 1990) a utilização de reduzidas TAS podem comprometer a eficiência de molhamento dos meios suporte com elevada superfície específica acarretando a obtenção de reduzidas taxas de remoção de $\mathrm{N}-\mathrm{NH}_{3}$, isso ocorre porque regiões não molhadas não formam biofilme e portanto não contribuem na degradação do efluente.

CRINE et. al. (1990) apud Fonseca (2009) reporta da literatura uma fórmula que permite avaliar a eficiência de molhamento de meio suporte e encontrase apresentada na Equação 3.9.

Entretanto, esta equação foi desenvolvida em filtros biológicos percoladores com distribuidor fixo de esgoto. 
$\mathrm{Ef}(\%)=\mathrm{TAS} /[\mathrm{TAS}+(\check{\times} \times \mathrm{As})]$

\section{Equação 3.9}

Onde:

Ef $(\%)=$ Eficiência de molhamento;

TAS = taxa de aplicação superficial total (incluindo recirculação) $\left(\mathrm{m}^{3} / \mathrm{m}^{2} . d\right)$; 广́ = Taxa de fluxo periférico;

As = Área superficial específica do meio suporte $\left(\mathrm{m}^{2} / \mathrm{m}^{3}\right)$.

Quanto ao valor que deve ser atribuído para a constante " $\Gamma$ ", o autor com base em dados de seu experimento sugere a aplicação de um valor médio de 0,113 .

\subsubsection{Desempenho de FBPs na remoção de nitrogênio amoniacal}

Este item apresenta as principais características e desempenhos médios obtidos por filtros biológicos percoladores (FBPs) destinados à remoção de $\mathrm{N}$-amoniacal.

De uma maneira geral, observa-se que todos os sistemas que operaram com cargas orgânicas volumétricas (COV) em torno ou acima de 0,60 $\mathrm{kgDBO} / \mathrm{m}^{3}$.d não demonstraram-se capazes de efetuar reduções substanciais em termos de concentrações de amônia. Em contrapartida, os FBPs que operaram com COVs próximas de $0,20 \mathrm{kgDBO} / \mathrm{m}^{3} . \mathrm{d}$ apresentaram baixas concentrações efluentes de $\mathrm{N}$-amoniacal. Ressalta-se que em alguns casos, mesmo com aplicação de taxas hidráulicas próximas de $20 \mathrm{~m}^{3} / \mathrm{m}^{2} . d$, os FBPs apresentaram um bom desempenho na remoção de amônia. As alturas dos leitos dos filtros, assim como o potencial de umedecimento do meio suporte, dada as taxas hidráulicas aplicadas, certamente podem ter influenciado no desempenho dos filtros biológicos percoladores que serão apresentados na Tabela 3.8 . 
Tabela 3.8: Principais características e desempenhos de filtros biológicos percoladores em sistemas de tratamento de esgotos domésticos

\begin{tabular}{|c|c|c|c|c|c|c|c|c|c|c|c|c|c|c|}
\hline \multicolumn{4}{|c|}{ Caracteristicas operacionais } & \multicolumn{4}{|c|}{ Características do filtro biológico percolador } & \multicolumn{3}{|c|}{ Conœentraçōes afluentes } & \multicolumn{3}{|c|}{ Conœentraç̧̌es efluentes } & \multirow[b]{2}{*}{ Referência } \\
\hline $\begin{array}{l}\text { Vazăo } \\
\text { (m/d) }\end{array}$ & $\begin{array}{c}\mathrm{COV} \\
\left(\mathrm{kgDBO} / \mathrm{m}^{3} \cdot \mathrm{d}\right)\end{array}$ & $\begin{array}{c}\text { TAS } \\
\left(\mathrm{m}^{3} / \mathrm{m}^{2} \mathrm{~d}\right)\end{array}$ & $\begin{array}{l}\text { Temp. } \\
{ }^{\circ} \mathrm{C}\end{array}$ & $\begin{array}{l}\text { Área } \\
\left(\mathrm{m}^{2}\right)\end{array}$ & $\begin{array}{c}\text { altura } \\
\text { (m) }\end{array}$ & $\begin{array}{c}\text { volume } \\
\left(\mathrm{m}^{3}\right) \\
\end{array}$ & $\begin{array}{c}\text { Meio suporte } \\
\left(\mathrm{m}^{2} / \mathrm{m}^{3}\right)\end{array}$ & $\begin{array}{l}\mathrm{DBO}_{3} \\
(\mathrm{mg} \mathrm{L})\end{array}$ & $\begin{array}{r}\text { SST } \\
(\mathrm{mg} / \mathrm{L}) \\
\end{array}$ & $\begin{array}{c}\mathrm{NH}_{3} \\
(\mathrm{mg} / \mathrm{L}) \\
\end{array}$ & $\begin{array}{l}\mathrm{DBO} \\
(\mathrm{mgl} /) \\
\end{array}$ & $\begin{array}{c}\text { SST } \\
(\mathrm{mgl}) \\
\end{array}$ & $\begin{array}{c}\mathrm{NH}_{3} \\
(\mathrm{mg} / \mathrm{L}) \\
\end{array}$ & \\
\hline 23,45 & 0,59 & 13,44 & 12 & 1,7 & 2,08 & 3,6 & Pedra (50) & 102 & - & 9,5 & $\cdot$ & $\sim 18$ & 8,1 & Harrisn \& Daigger (1987) \\
\hline 23,45 & 0,59 & 13,44 & 12 & 1,7 & 2,08 & 3,6 & Anéis (105) & 102 & - & 9,5 & - & 23 & 7,3 & Harnison \& Daigger (1987) \\
\hline 23,45 & 0,59 & 15,78 & 12 & 1,5 & 2,44 & 3,6 & Cross-flow (98) & 102 & - & 9,5 & - & $\sim 10$ & 4,8 & Harrisn \& Daigger (1987) \\
\hline 12,48 & $1,18-1,78$ & 12,48 & $15-19$ & 1,000 & 2,10 & 2,1 & Escória $(40)$ & $200-300$ & 165 & 53,1 & 174 & 142 & 52,1 & Bruce \& Merkens $(1970)$ \\
\hline - & $0,23-0,29$ & - & - & - & $1,8-1,5$ & - & Cross-flow (100) & - & - & - & - & - & $10-20$ & Peare (2004) \\
\hline 113,5 & 0,50 & 0,07 & $19-27$ & 1432,0 & 4,9 & 7016,8 & Cross-flow (100) & 165 & 98 & 21 & - & - & 8,4 & Parker \& Richards (1986) \\
\hline 28504,1 & 0,21 & 19,93 & $23-28$ & 1430,0 & 2,89 & 13586,2 & Escória $(66,1)$ & 101 & - & 20 & 7 & 9 & 2,61 & EPA (1991) \\
\hline 105991,2 & - & 64,59 & - & 1641,0 & 1,21 & 2000,7 & Pedra & - & - & - & 25 & 10 & 17 & EPA (1991) \\
\hline 2309,1 & 0,19 & 12,65 & $17-21$ & 182,4 & 8,53 & 1555,9 & Plástico $(98,4)$ & 127 & - & 17,4 & 10 & $<5$ & 0,7 & EPA (1991) \\
\hline 3028,3 & - & 6,49 & - & 466,9 & 1,82 & 849,8 & Pedra & - & - & - & 12 & 21 & 0,6 & EPA (1991) \\
\hline 132489 & - & 92,64 & - & 1430,1 & 7,31 & 10461,5 & Pedra & - & - & - & 5 & 17 & 0,5 & EPA (1991) \\
\hline 7684,4 & 0,28 & 22,98 & $17-20$ & 334,4 & 5,18 & 1732,2 & Plástico $(99,7)$ & 62 & - & 14,7 & 7,5 & $<10$ & 1,7 & EPA (1991) \\
\hline 124161,1 & 2,13 & 23,09 & $17-19$ & 729,7 & 9,75 & 7117,2 & Plástico $(97,4)$ & 122 & - & 13,1 & 50 & 30 & 10,0 & EPA (1991) \\
\hline
\end{tabular}




\subsubsection{Materiais de preenchimento utilizados em FBPs}

Os materiais de enchimento convencionalmente utilizados em filtros biológicos percoladores são a brita, aneis plásticos randômicos (anéis Paul) e blocos cross-flow. Atualmente novos meios suporte tem sido testados, com destaque para os eletrodutos, os blocos de plástico corrugados e os sistemas Donwflow Hanging Sponge.

O custo de aquisição dos materiais sintéticos são mais elevados em comparação com o custo da brita de granulometria $n^{\circ} 4$, portanto nos paises em desenvolvimento o uso de pedra britada ainda é predominante.

Outro aspecto importante diz respeito às cargas orgânicas volumétricas aplicadas e a taxa de aplicação superficial; os materiais sintéticos são geralmente mais eficientes na remoção de matéria orgânica e nitrogênio amoniacal, tendo em vista as maiores áreas superficiais específicas e índices de vazios. Estas características permitem biomassa aeróbia no sistema em percentuais mais elevados em virtude da maior presença de oxigênio na reação; no entanto Parker \& Richards (1986) relatam que anéis plásticos foram menos eficientes na remoção de amônia quando comparados com filtros preenchidos com leito de pedras e blocos cross-flow.

A Tabela 3.9 indica os diferentes materiais de meio suporte e suas principais características. 
Tabela 3.9 : Principais características de material de enchimento

\begin{tabular}{|c|c|c|c|}
\hline Material & $\begin{array}{c}\text { Peso específico } \\
\left(\mathrm{Kg} / \mathrm{m}^{3}\right)\end{array}$ & $\begin{array}{c}\text { Superfície Específica } \\
\left(\mathrm{m}^{2} / \mathrm{m}^{3}\right)\end{array}$ & $\begin{array}{c}\text { Índice de vazios } \\
\text { (\%) }\end{array}$ \\
\hline Pedra britada & $800-1400$ & $50-70$ & 50 \\
\hline Bloco Cross-Flow $60^{\circ}$ & 30 & 98 & 95 \\
\hline Bloco Cross-Flow $45^{\circ}$ & 30 & 98 & 95 \\
\hline Bloco Vertical Flow & 30 & 88 & 97 \\
\hline Anel Randômico (Ø 84mm) & - & 80 & - \\
\hline Anel Randômico (Ø 48mm) & 50 & 105 & 92 \\
\hline Escória de alto forno & 1110 & 40 & 50 \\
\hline DHS ("sponge-cube") & - & 405 & 80 \\
\hline DHS ("curtain-type") & - & - & 80 \\
\hline Conduíte corrugado $(\varnothing 84 \mathrm{~mm})$ & - & 220 & 95 \\
\hline
\end{tabular}

Fonte: Adaptado de Fonseca (2009)

Os estudos de Bruce \& Merkens (1970) e Harrison \& Daigger (1987) indicam que outras características associadas ao material de enchimento podem influenciar o desempenho de filtros biológicos percoladores. A configuração do meio suporte e a rugosidade do material são apontados como sendo importantes em termos do efeito produzido pelos materiais de enchimento no desempenho de FBPs.

Em relação à influência da rugosidade de materiais de enchimento Bruce \& Merkens (1970) comparam a eficiência de FBPs preenchidos com escória de alto-forno (superfície rugosa) e brita de rocha basáltica (superfície lisa) considerando as mesmas condições operacionais para os reatores. Embora a escória de alto-forno e a brita de rocha basáltica possuam aproximadamente a mesma área superficial específica e índice de vazios, os resultados apontam um melhor desempenho da escória de alto-forno em termos de remoção de de DQO e DBO. Os autores atribuem tais diferenças de desempenho à rugosidade do material, o que garante melhores condições de estabelecimento da biomassa, e o biofilme pode ter uma menor propensão ao desprendimento.

Ainda com relação ao efeito de diferentes materiais suportes utilizados em FBPs com remoção de matéria orgânica e $\mathrm{N}$-amoniacal, Parker \& Richards 
(1986) afirmam que anéis plásticos randômicos foram menos eficientes que leito de pedras na nitrificação. Comportamento distinto foi verificado por Harrisson \& Daigger (1987), onde para uma carga orgânica volumétrica aplicada de $0,59 \mathrm{kgDBO} / \mathrm{m}^{3} . \mathrm{d}$ os anéis plásticos randômicos tiveram desempenho superior ao leito de pedras. As diferenças nos estudos mencionados podem estar associadas às condições operacionais impostas para ambos os sistemas, dada a sensibilidade que cada meio suporte possui, sob a perspectiva de taxas de aplicação superficial.

A Figura 3.11 apresenta os meio suporte mais utilizados em FBPs.

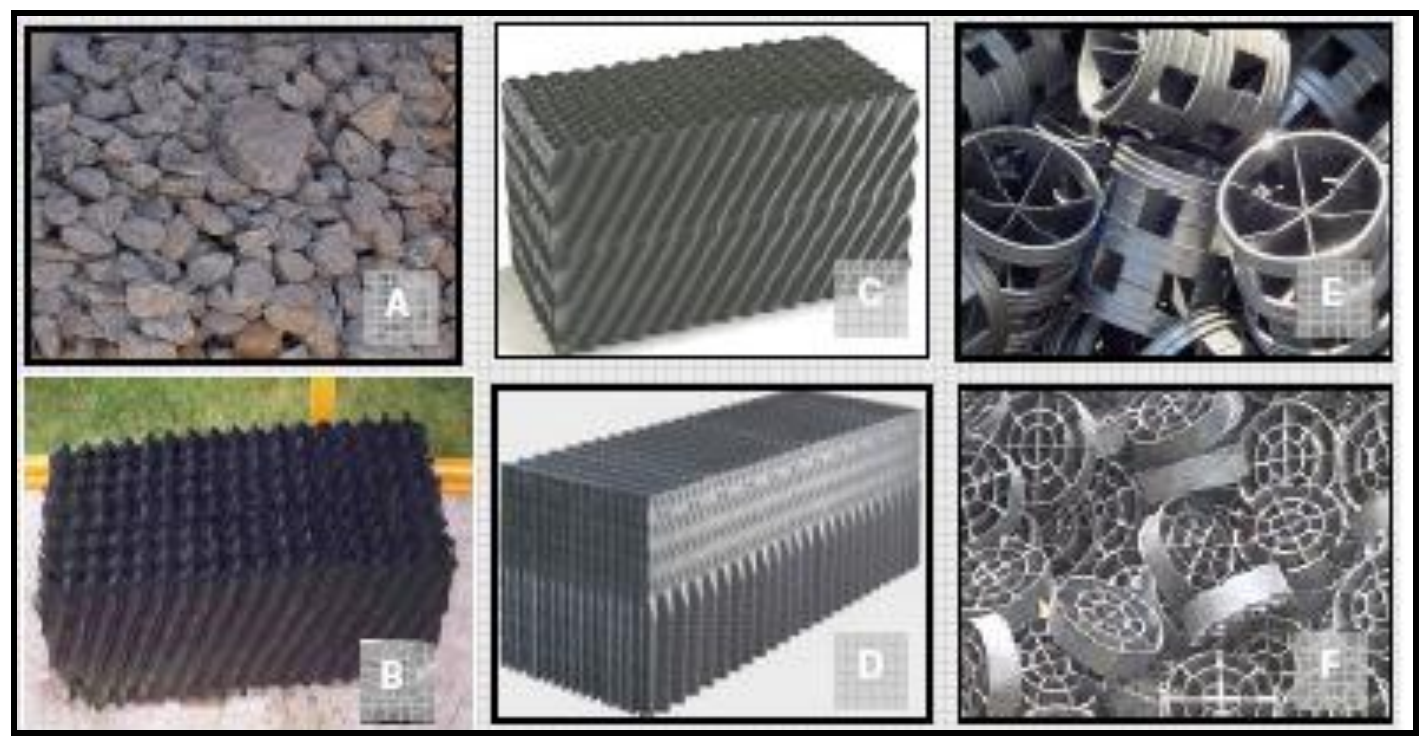

Figura 3.11 - Principais Tipos de meio suporte normalmente utilizados em FBP. (A) Pedra Britada (B) Bloco Crossflow 60 (C) Bloco Crossflow 45, (D) Bloco Vertical Flow, (E) Anel Randômico (Ø 84mm) e (F) Anel Randômico ( $\varnothing$ $48 \mathrm{~mm})$.

Fonte: Fonseca (2009) apud ALMEIDA (2007) 


\subsection{Filtro Biológico Percolador como pós tratamento de efluentes de lagoas de estabilização}

\subsubsection{Aplicabilidade da tecnologia na remoção de amônia}

O que mais contribui para a aceitação da tecnologia dos filtros biológicos percoladores (FBPs) é a não necessidade de aeração forçada para o fornecimento de oxigênio aos microrganismos envolvidos no processo de remoção de alguns constituintes presentes nos esgotos, como a matéria orgânica carbonácea e $\mathrm{N}$-amoniacal, além da tolerância a alterações de qualidade do afluente e a simplicidade operacional e de manutenção.

Sistemas convencionais utilizando filtros biológicos percoladores são capazes de fornecer concentrações efluentes em torno de $10 \mathrm{mgDBO} / \mathrm{L}, 10$ $\mathrm{mgSST} / \mathrm{L}$ e concentrações efluentes de $\mathrm{N}$-amoniacal de $1 \mathrm{mg} / \mathrm{L}$ ou menos (OLIVEIRA, 2009 apud WEF). No entanto, deve-se ressaltar que os sistemas convencionais que produzem efluentes com baixas concentrações de matéria orgânica, sólidos suspensos e $\mathrm{N}$-amoniacal freqüentemente possuem materiais de enchimento de elevada área superficial específica (usualmente blocos crossflow: 100 a $250 \mathrm{~m}^{2} / \mathrm{m}^{3} . d$ ), alturas elevadas (freqüentemente acima de 4 metros), ou ainda, baixas taxas de aplicação superficiais (freqüentemente abaixo de $4 \mathrm{~m}^{3} / \mathrm{m}^{2} . \mathrm{d}$ ).

Com relação ao pós-tratamento de efluentes de lagoas com filtros biológicos aeróbios, não são disponíveis modelos seguros capazes de definir as condições necessárias para a obtenção de determinadas concentrações de amônia no efluente final.

A concentração de DBO relativamente baixa dos efluentes das lagoas facultativas podem permitir que se consiga a nitrificação sem a necessidade de grandes volumes de filtros, e o limite relativamente alto a ser alcançado 
pode fazer com que se possa pós-tratar apenas uma parte do efluente, reduzindo-se custos.

Existem varias concepções de filtros biológicos utilizados como póstratamento de efluente de lagoas; a concepção mais elaborada pode ser considerada o processo PETRO (Pond Enhanced Treatment and Operation), processo desenvolvido por Meiring et al (1995) que compreende um sistema composto por um reator aeróbio/anaeróbio com câmara de fermentação, seguido de lagoa de estabilização, filtro percolador e tanque de sedimentação de lodo. O lodo em excesso, proveniente da câmara de fermentação, deve ser disposto num leito de secagem.

O processo remove algas por adsorção no biofilme que se desenvolve sobre o meio suporte do filtro percolador. Isso é possível graças à alimentação mista (efluente de lagoas e efluente do tanque anaeróbio), que permite o desenvolvimento de um biofilme predominantemente heterotrófico, capaz de adsorver algas.em que uma câmara aeróbia/anaeróbia é instalada a montante da lagoa. Deste reator se desvia uma fração de esgoto diretamente para o filtro, que é alimentado também pelo efluente da lagoa. Esta câmara recebe também um fluxo de recirculação do efluente da lagoa. O esquema do Processo PETRO pode ser visto na Figura 3.12.

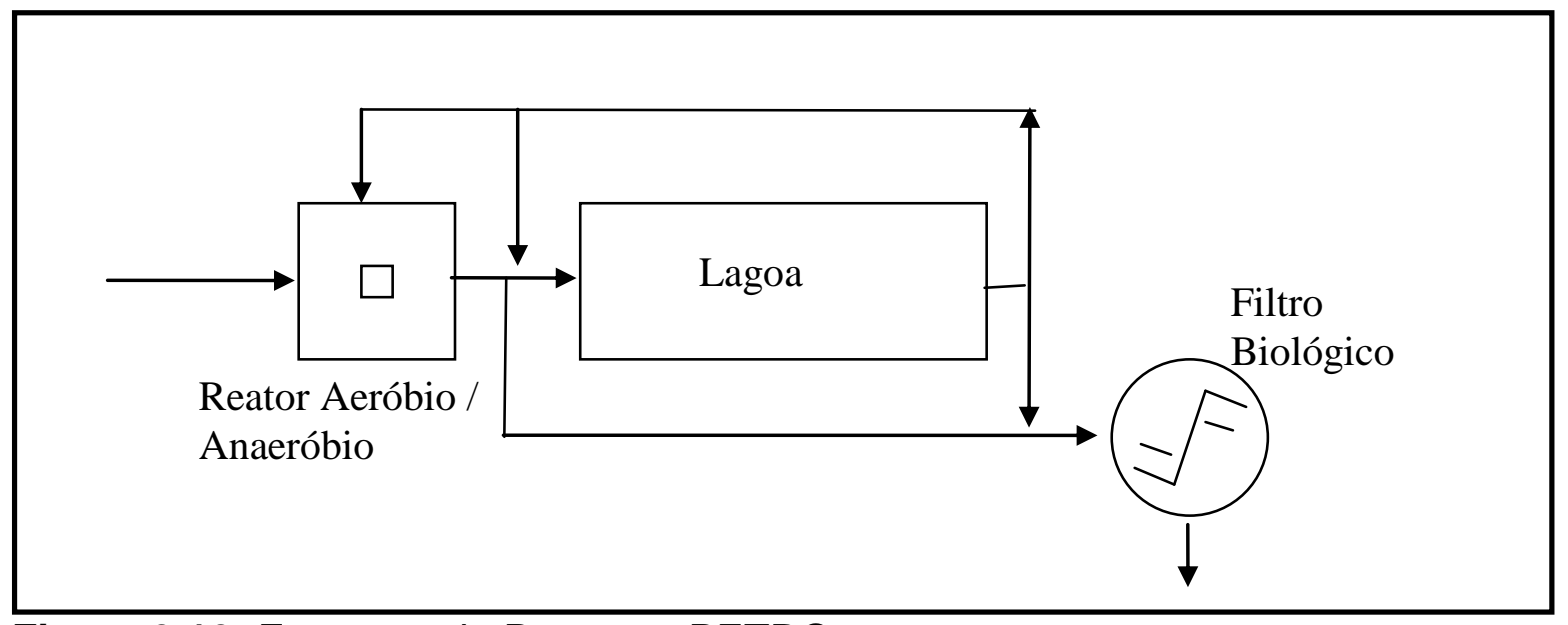

Figura 3.12: Esquema do Processo PETRO. 
A aplicação deste processo, resultou em $98 \%$ de remoção de nitrogênio amoniacal em sistema implantado na África do Sul.

\subsubsection{Desempenho de filtros biológicos operando como pós tratamento de efluente de lagoas}

São apresentadas algumas experiências de filtros biológicos utilizados como pós-tratamento de efluentes de lagoas, com vistas à discussão dos aspectos operacionais e configurações de projeto capazes de promover a remoção de $\mathrm{N}$-amoniacal e matéria orgânica ao nível desejado.

\section{- Processo PETRO}

A Tabela 3.10 apresenta os resultados obtidos em Kanyamazane (África do Sul) utilizando o processo PETRO com dois filtros percoladores operando em paralelo.

Tabela 3.10 - Processo PETRO operando com dois filtros percoladores em paralelo em Kanyamazane (Agosto, 1994)

\begin{tabular}{|l|c|c|c|}
\hline Parâmetros & $\begin{array}{l}\text { Efluente } \\
\text { Lagoa }\end{array}$ & $\begin{array}{c}\text { Saída Filtro 1 } \\
\text { (Alta carga) }\end{array}$ & $\begin{array}{c}\text { Saída Filtro 2 } \\
\text { (Baixa carga) }\end{array}$ \\
\hline SS $(\mathrm{mg} / \mathrm{l})$ & 46 & 23 & 28 \\
\hline DQO $(\mathrm{mg} / \mathrm{l})$ & 150 & 96 & 80 \\
\hline DQOf $(\mathrm{mg} / \mathrm{l})$ & - & 36 & 28 \\
\hline $\mathrm{NKT}(\mathrm{mg} / \mathrm{l})$ & 28 & 5,6 & 5,6 \\
\hline $\mathrm{N}-\mathrm{NH} 3(\mathrm{mg} / \mathrm{l})$ & 24 & 4 & 3,8 \\
\hline $\mathrm{N}-\mathrm{NO} 3(\mathrm{mg} / \mathrm{l})$ & 0,3 & 26 & 31 \\
\hline
\end{tabular}

Fonte: Adaptado de Meiring ( 1995 )

Além de remover algas, o processo PETRO obtem a nitrificação do efluente de lagoas. Por suportar baixas taxas, e ser composto por uma série de unidades, demanda uma área considerável para a sua implantação.

- Biofiltro Aerado Submerso 
Oliveira e Gonçalves, 1999 utilizaram como pós-tratamento de efluentes de lagoas de estabilização facultativas uma piloto de Biofiltro Aerado Submerso. Os testes foram realizados em um reator biofiltro com $200 \mathrm{~mm}$ de diâmetro e 3,5 m de altura, dotado de um meio granular flutuante. A tecnologia baseiase na introdução de esgoto na base do reator, que atravessa em fluxo ascendente um leito filtrante, de 2,5 $\mathrm{m}$ de altura, composto por pequenas bilhas de poliestireno (diâmetro entre 3 e $6 \mathrm{~mm}$ ) totalmente aerado e mantido flutuante no interior do reator por uma placa perfurada situada na sua parte superior. A carga hidráulica imposta foi de $1,9 \mathrm{~m} / \mathrm{h}\left(45,6 \mathrm{~m}^{3} / \mathrm{m}^{2} . \mathrm{d}\right)$, sendo mantida constante durante todo o período de testes.

O biofiltro operou segundo diversas configurações de alimentação (efluente das lagoas e mistura de eflluente lagoas com esgoto bruto) e aeração (com e sem aeração), com vistas à remoção de algas e nitrificação terciária. Os melhores resultados obtidos estão apresentados na Tabela 3.11, e se referem ao reator aerado e alimentado pela mistura de efluente de lagoa e esgoto bruto.

Tabela 3.11 - Resultados obtidos na entrada e saída do biofiltro submerso

\begin{tabular}{|c|c|c|c|c|c|c|c|c|}
\hline \multirow{2}{*}{} & \multicolumn{2}{|c|}{$\mathrm{SS}(\mathrm{mg} / \mathrm{l})$} & \multicolumn{2}{c|}{$\mathrm{DQO}(\mathrm{mg} / \mathrm{l})$} & \multicolumn{2}{c|}{$\mathrm{N}^{-\mathrm{NH}_{3}}(\mathrm{mg} / \mathrm{l})$} & \multicolumn{2}{c|}{$\mathrm{P}$ total $(\mathrm{mg} / \mathrm{l})$} \\
\cline { 2 - 9 } & Entrada & Saída & Entrada & Saída & Entrada & Saída & Entrada & Saída \\
\hline Média & 71 & 31 & 207 & 85 & 23,7 & 3 & 2,3 & 1,5 \\
\hline
\end{tabular}

Fonte: Oliveira e Gonçalves, 1999

Verificou-se uma eficiência média de $54 \%$ na remoção de SS, para uma carga volumétrica média aplicada de $1,4 \mathrm{Kg} \mathrm{SS} / \mathrm{m}^{3}$.d. As taxas volumétricas médias de nitrificação situaram-se em torno de $0,47 \mathrm{Kg} \mathrm{N}^{-\mathrm{NH}_{4}+} / \mathrm{m}^{3} \cdot \mathrm{d}\left(25^{\circ} \mathrm{C}\right)$, com as concentrações na faixa de $20 \mathrm{mg} \mathrm{N}-\mathrm{NH}_{4}{ }^{+} / l$ na entrada do Biofiltro

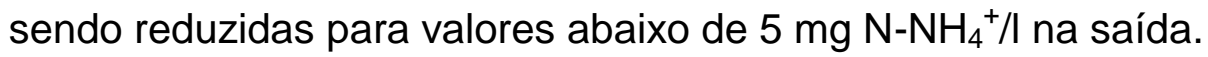

A qualidade do efluente produzido pelo biofiltro submerso atende a padrões mais restritivos, inclusive no que tange a remoção do nitrogênio amoniacal (nitrificação). Suportam cargas hidráulicas muito superiores aos outros 
processos, o que reflete numa demanda muito menor de área para a sua implantação, podendo ser inserido dentro da área da lagoa. Apresenta como desvantagem a necessidade de aeração contínua, o que eleva seu custo operacional.

- Filtro de Pedra Submerso

Middlebrooks (1988) apresenta informações detalhadas sobre a operação dos filtros de pedra no polimento do efluente de lagoas em diversas localidades nos E.U.A. Segundo o autor, nas regiões em que os teores de N$\mathrm{NH}_{4}{ }^{+}$passaram a ser considerados importantes pelos órgãos de controle ambiental, a tecnologia caiu em desuso por não serem capazes de remover este composto. De simples operação e baixo custo, consiste em fazer passar o líquido a ser tratado por um leito, normalmente formado por pedras de $100 \mathrm{~mm}$ de diâmetro, com profundidade variando entre 1,5 e 2,0 m. A remoção das algas ocorre por deposição na superfície e nos vazios das pedras, onde são acumuladas e degradadas biologicamente, liberando nutrientes que serão utilizados para o crescimento de bactérias aderidas à superfície dessas pedras.

Após avaliar a operação de 13 sistemas de filtros de pedras, a EPA concluiu que os mesmos apresentam efluentes com concentrações médias de 30 $\mathrm{mg} / \mathrm{l} \mathrm{em} \mathrm{DBO}_{5}$ e $37 \mathrm{mg} / \mathrm{l}$ em SS para uma carga hidráulica máxima de 0,80 $\mathrm{m}^{3} / \mathrm{m}^{2}$.d. 


\section{MATERIAL E MÉTODOS}

\subsection{Descrição da Estação de Tratamento de Esgoto de Lins-SP}

A cidade possui, hoje, aproximadamente 74.000 habitantes, 99,5\% da população é atendida pelo sistema de coleta e 100\% deste esgoto recebe tratamento de esgoto, resultando em uma vazão média de $12.000 \mathrm{~m}^{3}$ de esgoto por dia. O esgoto é coletado e levado para as estações elevatórias, onde é recalcado através de moto-bombas para a Estação de Tratamento. 0 tratamento é feito através Lagoas de estabilização pelo Sistema Australiano, Lagoa Anaeróbia seguida de Lagoa Facultativa.

O esgoto ao chegar à Estação é submetido a um tratamento preliminar, constituído por gradeamento seguido de uma unidade de desarenação de limpeza manual e medição de vazão através de Calha Parshall. $\mathrm{Na}$ seqüência a vazão é dividida em três partes iguais que alimentam os três conjuntos em paralelo de lagoa anaeróbia seguida de lagoa facultativa. $O$ efluente das lagoas facultativas é lançado diretamente no corpo receptor, o Rio Campestre.

O campo experimental foi instalado na estação de tratamento de esgoto e é alimentado pelos efluentes do primeiro conjunto de lagoas (anaeróbia + facultativa).

Um esquema e uma foto aérea da ETE de Lins estão respectivamente ilustrados nas Figuras 4.1 e 4.2. 


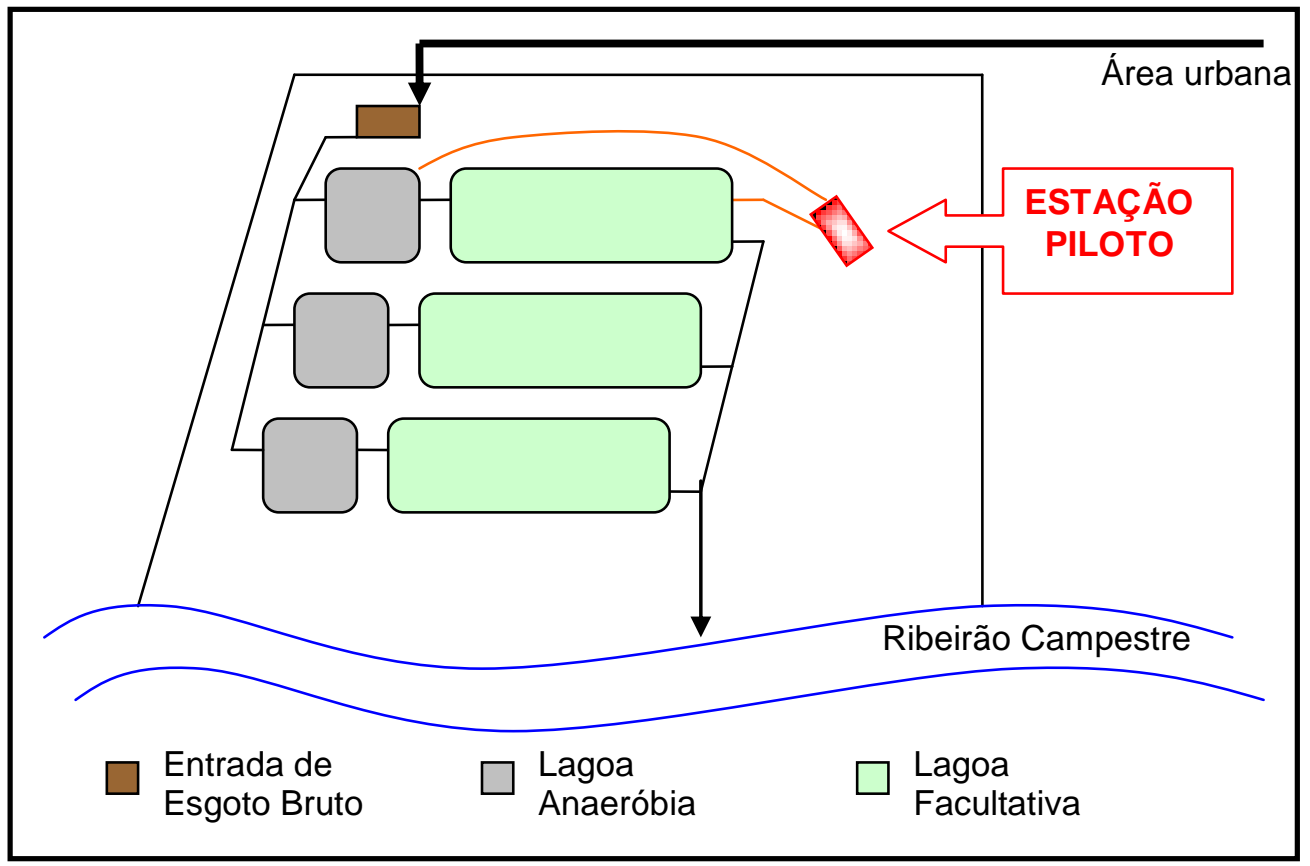

Figura 4.1: Esquema da ETE de Lins

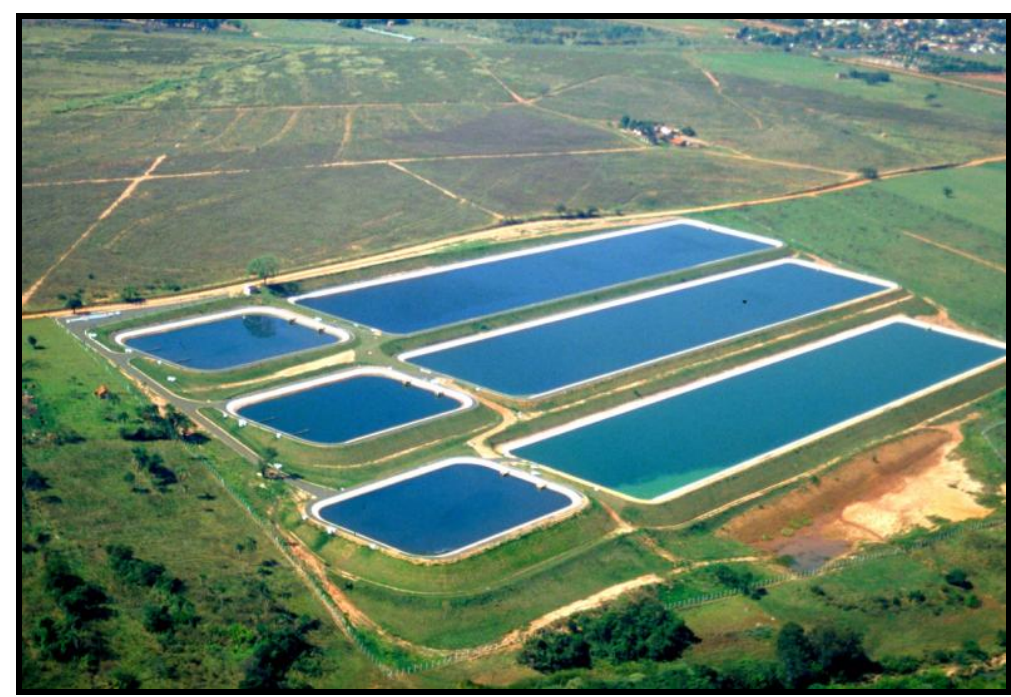

Figura 4.2: Foto aérea da ETE de Lins

A Tabela 4.1 contém o detalhamento das condições operacionais da ETE de Lins-SP. 
Tabela 4.1: Dados de Projeto do Sistema de Lagoas de Estabilização de Lins/SP. Fonte: SABESP, 1997

\begin{tabular}{|c|c|c|}
\hline Dados de Projeto & $\begin{array}{c}\text { Lagoa } \\
\text { anaeróbia }\end{array}$ & $\begin{array}{c}\text { Lagoa } \\
\text { Facultativa }\end{array}$ \\
\hline População atendida (habitantes) & 67.000 & 67.000 \\
\hline Vazão média de esgoto (m³/dia) & 12.000 & 12.000 \\
\hline Carga de DBO (kg/dia) & 3.012 & 1.506 \\
\hline Comprimento $(\mathrm{m})$ & 106,25 & 404,75 \\
\hline Largura (m) & 64,25 & 77,75 \\
\hline Área superficial da lagoa $\left(\mathrm{m}^{2}\right)$ & $6.826,6$ & $31.469,3$ \\
\hline Área superficial total $\left(\mathrm{m}^{2}\right)$ & $20.479,68$ & $94.407,9$ \\
\hline $\begin{array}{l}\text { Taxa de aplicação superficial de } \\
\text { (kg/ha.d) }\end{array}$ & $1.470,7$ & $159,5\left(^{*}\right)$ \\
\hline Profundidade útil (m) & 4,1 & 1,9 \\
\hline Inclinação dos taludes (V:H) & $1: 1$ & $1: 1$ \\
\hline Volume útil por lagoa $\left(\mathrm{m}^{3}\right)$ & $23.227,0$ & $55.528,87$ \\
\hline Volume útil total $\left(\mathrm{m}^{3}\right)$ & $69.681,1$ & $166.586,6$ \\
\hline Tempo de retenção hidráulica (dias) & 5,8 & 13,9 \\
\hline $\begin{array}{l}\text { Taxa de aplicação volumétrica de DBO } \\
\left(\mathrm{kg} / \mathrm{m}^{3} . \mathrm{d}\right)\end{array}$ & 0,043 & $0,009\left(^{*}\right)$ \\
\hline
\end{tabular}

$\left.{ }^{*}\right)$ Considerada a eficiência de $50 \%$ na remoção de DBO pelas lagoas anaeróbias.

\subsection{Descrição das Instalações do campo experimental}

A ETE piloto foi instalada no campo experimental localizado na ETE de Lins e recebe efluente da lagoa facultativa.

No campo experimental foram construídos dois filtros biológicos, e para cada um segue um decantador; ambos em escala piloto. Os filtros operam como leitos percoladores, um foi preenchido com brita e o outro com material 
plástico, para efeito de comparação. O fluxograma de todo processo compreendendo desde o tratamento preliminar até os decantadores é mostrado na Figura 4.3: 


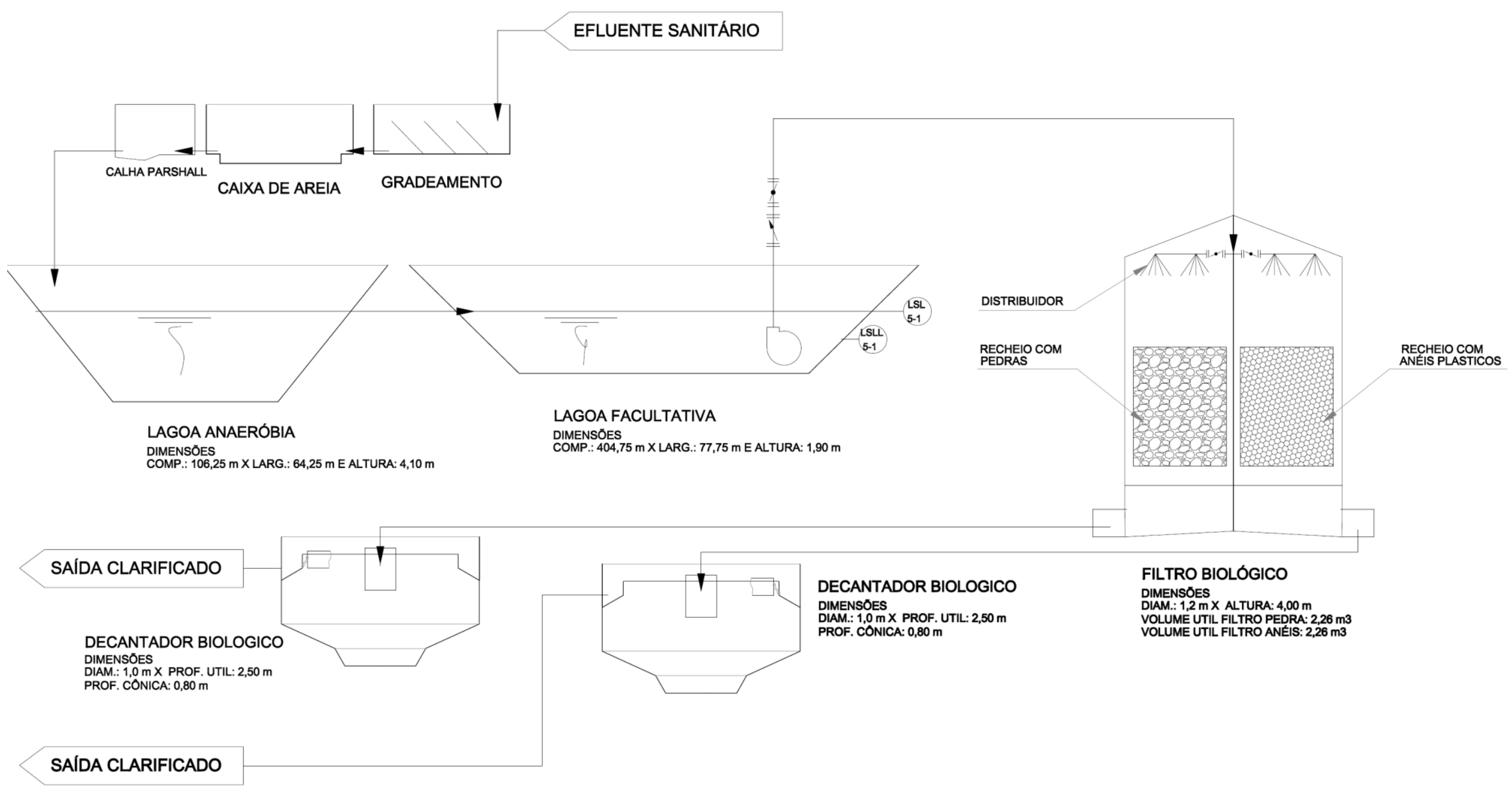

Figura 4.3: Fluxograma de todo processo 
Não houve à princípio preocupação em localizar o sistema de modo a propiciar a sua alimentação por gravidade, portanto foi adotado um pequeno sistema de recalque do efluente facultativo até a unidade de pós-tratamento.

O efluente da lagoa facultativa chega a um tanque de equalização de onde parte uma ramificação que liga o sistema de recalque ao tanque. Na linha de recalque instalou-se um rotâmetro de alma cônica. Nas extremidades do rotâmetro foram instalados registros de agulhas possibilitando o controle da vazão. O sistema de controle da vazão conta ainda com um sistema bypass, que possibilita a operação, manutenção e escorvo da bomba quando sua operação é interrompida. A Figura 4.4 mostra uma foto do sistema de controle de vazão.

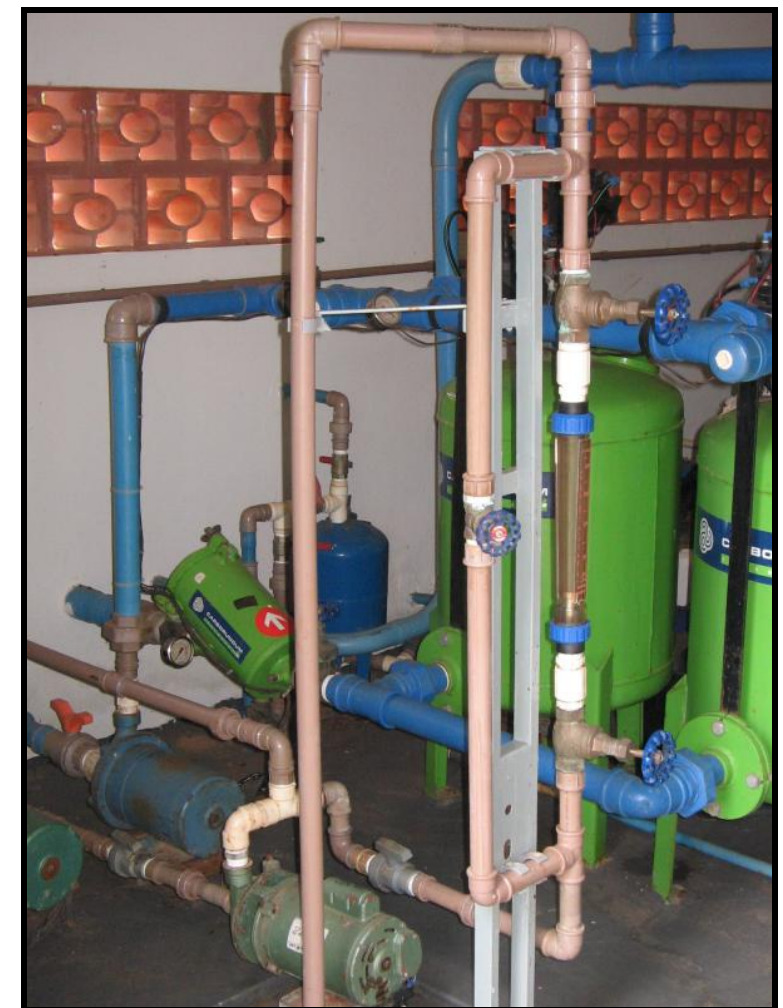

Figura 4.4: Sistema de controle de vazão

O esgoto, após ser recalcado ao topo do reator, era distribuído continuamente sobre o meio suporte e a vazão dividida igualmente para os dois filtros, por meio de um sistema de distribuição do tipo móvel, que era basicamente um distribuidor ligado a um redutor de velocidade. A conexão 
entre 0 redutor e o motor elétrico era feito através de duas roldanas conectadas por uma correia. O distribuidor foi construído a partir de uma tubulação de pvc perfurada, de $40 \mathrm{~mm}$ de diâmetro que tem o funcionamento semelhante a um aspersor de jardim. A estimativa de controle de velocidade de rotação do sistema foi feita através da Equação proposta por Metcalf \& Eddy, 2003:

$\eta=(1+R){ }^{*} q *(103 \mathrm{~mm} / \mathrm{m}) / A * D R *(60 \mathrm{~min} / \mathrm{h})$ Equação 4.1

sendo:

$\eta=$ velocidade de rotação, em $\mathrm{rpm}$

$\mathrm{q}=$ taxa de aplicação hidráulica, em $\mathrm{m}^{3} / \mathrm{m}^{2} \cdot h$

$\mathrm{R}=$ Razão de reciclo

$A=$ número de braços do distribuidor

$\mathrm{DR}=$ taxa de dosagem, $\mathrm{mm} /$ pass

Através dos cálculos obteve-se velocidade de rotação de $1 \mathrm{rpm}$.

As Figuras 4.5 e 4.6 ilustram o sistema de distribuição utilizado e a Figura 4.7 fornece uma vista geral do FBP. 


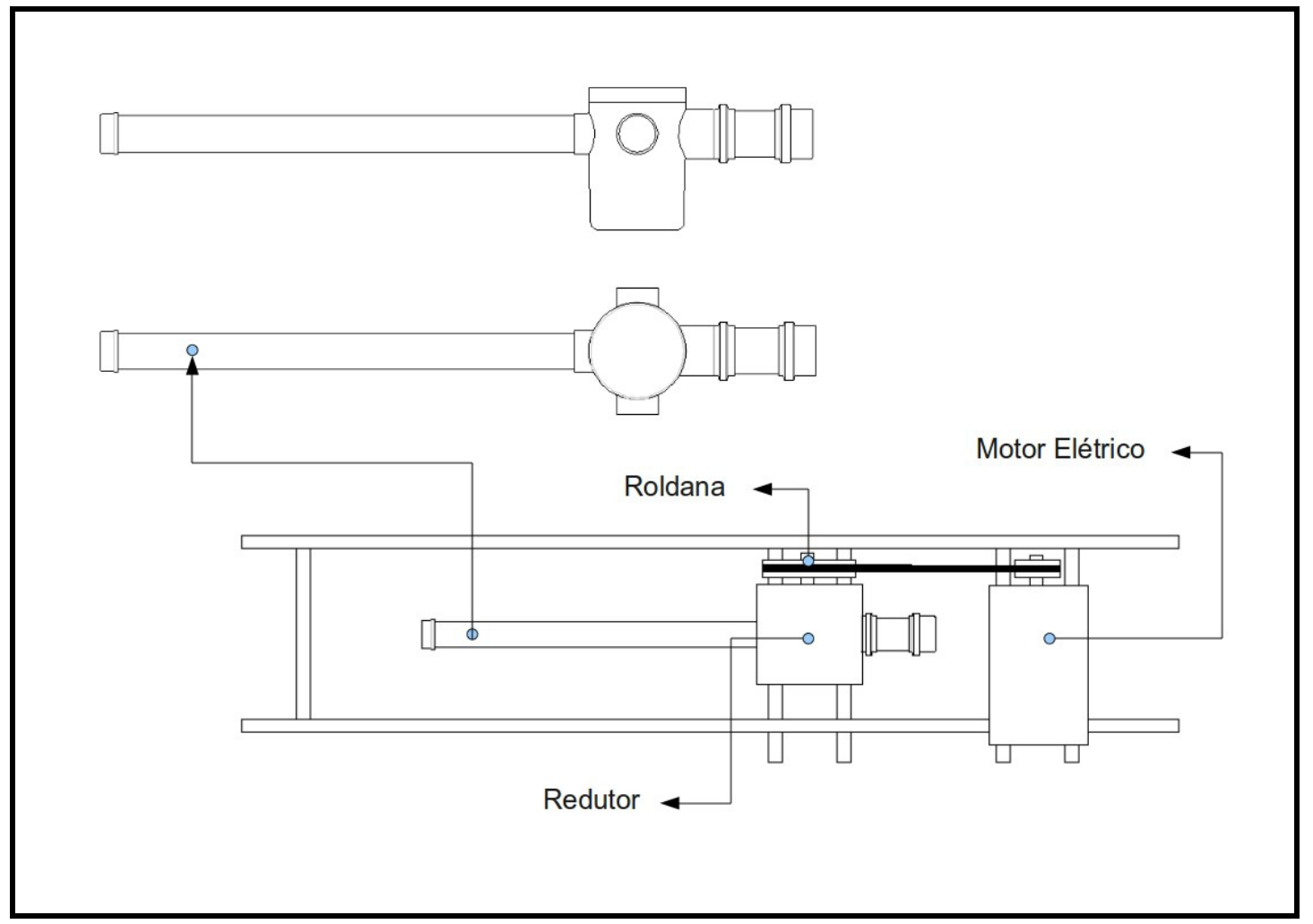

Figura 4.5: Características do Distribuidor

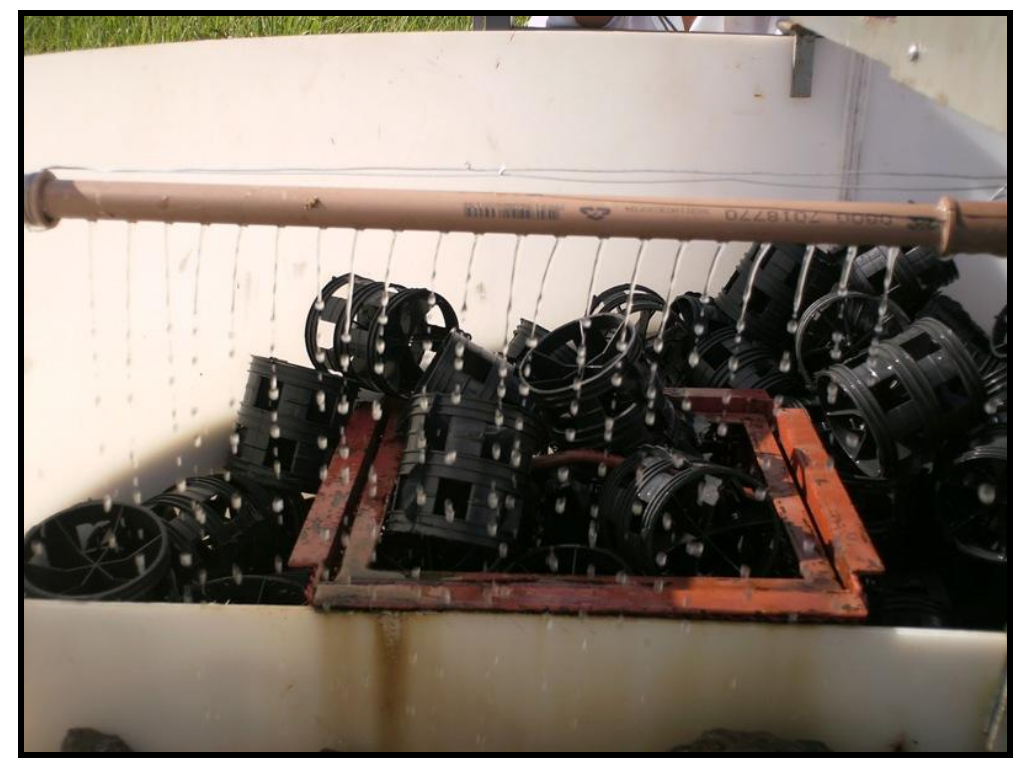

Figura 4.6: Distribuidor em funcionamento 


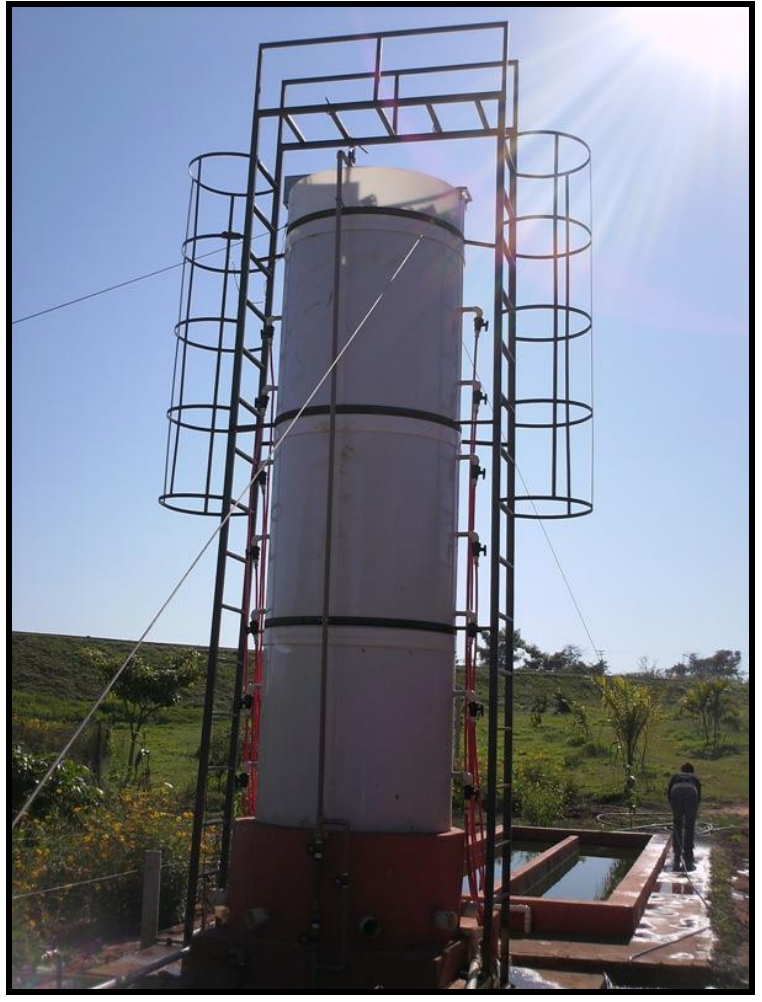

Figura 4.7: Vista geral do FBP

Os filtros foram construídos em um corpo único cilíndrico de polipropileno, com uma placa vertical em seu interior que o divide em dois compartimentos de mesmo volume, tendo-se preenchido um deles com pedra britada variando de 4 a 8, onde se admitiu-se uma área superficial específica de 70 $\mathrm{m}^{2} / \mathrm{m}^{3}$, e o outro com anéis plásticos de área superficial específica de 100 $\mathrm{m}^{2} / \mathrm{m}^{3}$, para efeito de comparação.

Os filtros foram construídos em polipropileno com 1,2 $\mathrm{m}$ de diâmetro. A altura útil do leito é de $4 \mathrm{~m}$. A área superficial total (dois filtros) é de 1,13 $\mathrm{m}^{2}$ e o volume útil total é de $4,52 \mathrm{~m}^{3}$. A área superficial disponível para a formação de biofilme é de $316,7 \mathrm{~m}^{2}$ no filtro preenchido com pedra e 542,9 $\mathrm{m}^{2}$ no filtro com material plástico, aproximadamente.

O filtro foi apoiado em uma base de concreto onde foram previstos drenos de fundo para adequada ventilação do filtro, garantindo uma concentração 
de oxigênio compatível para que o processo de nitrificação não fosse inibido.

As figuras 4.8 e 4.9 fornecem respectivamente uma vista de cima do FBP e detalhes construtivos do FBP e a Figura 4.10 ilustram os meios suportes, respectivamente:

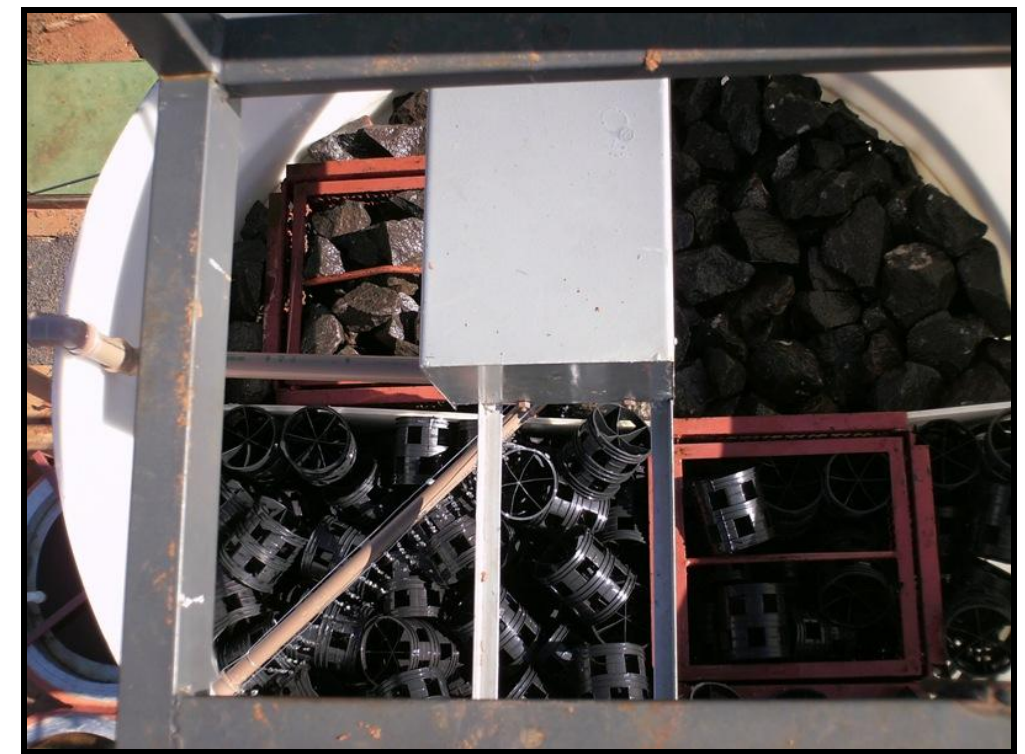

Figura 4.8: Vista de cima do FBP 


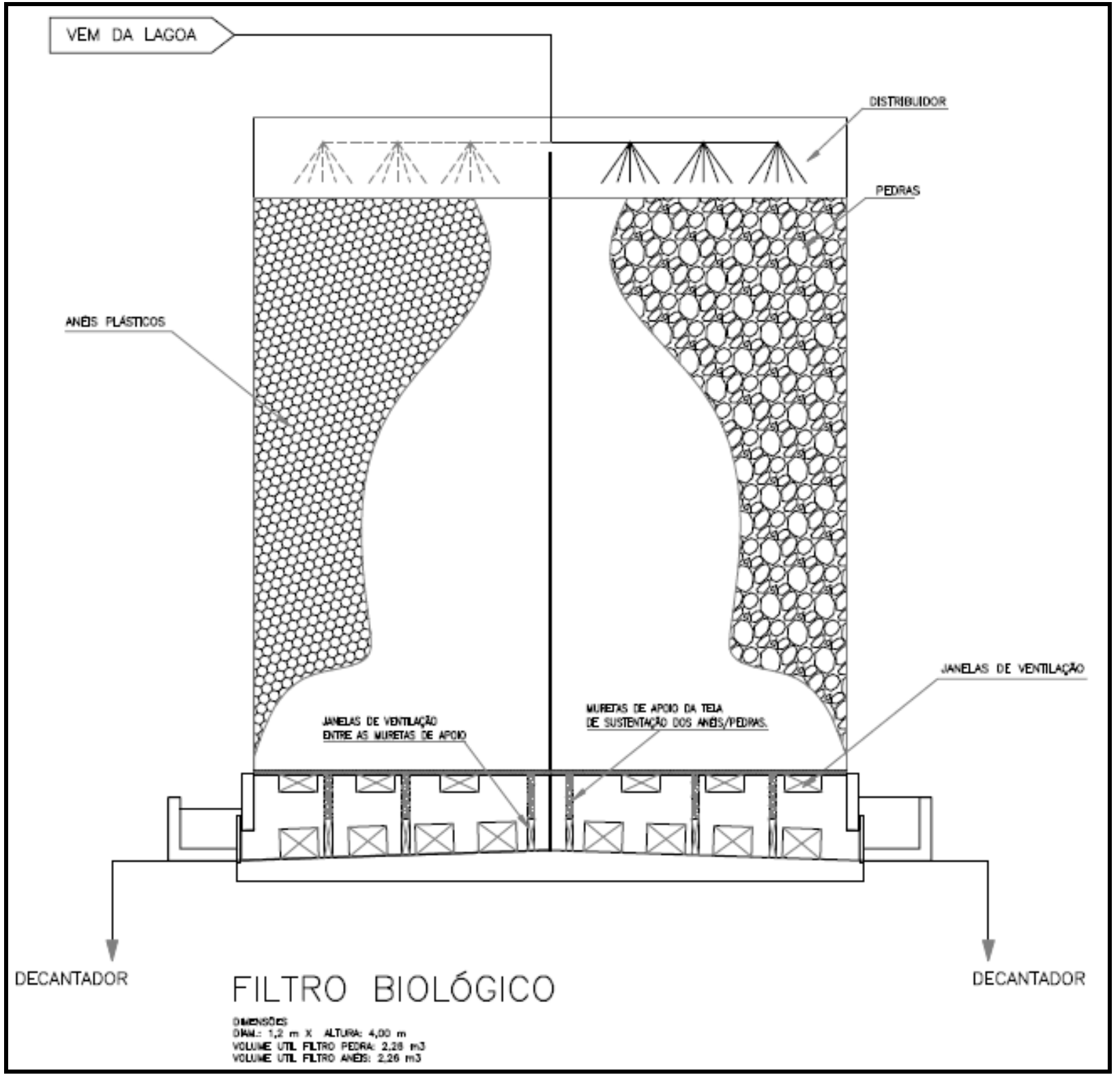

Figura 4.9: Detalhes construtivos do FBP 


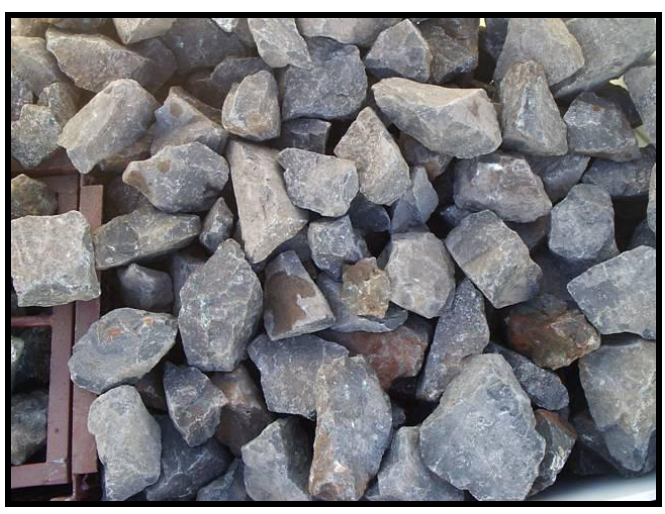

Figura 4.10: Meios suporte

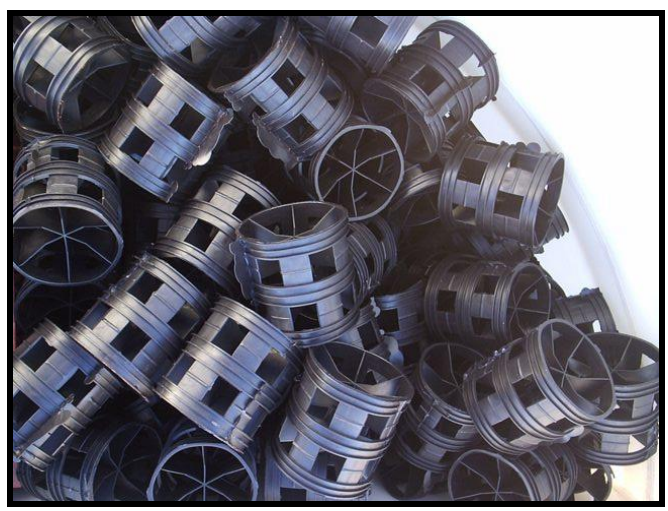

Após percolar o meio suporte, o esgoto era encaminhado a um decantador secundário através de um dreno de fundo localizado na base do FBP. Os decantadores foram dimensionados baseando-se em uma taxa de escoamento superficial máxima de $30 \mathrm{~m}^{3} / \mathrm{m}^{2}$.dia e vazão máxima de $23,6 \mathrm{~m}^{3} / \mathrm{d}$. Com essas duas considerações foi possível a construção dos decantadores utilizando aduelas de concreto com $1 \mathrm{~m}$ de diâmetro. A profundidade útil ficou estabelecida em $2,5 \mathrm{~m}$, sendo que o fundo, em forma de cone, tem $0,8 \mathrm{~m}$.

As Figuras 4.11 e 4.12 ilustram respectivamente a unidade de decantação secundária do FBP e os detalhes construtivos dos decantadores secundários.

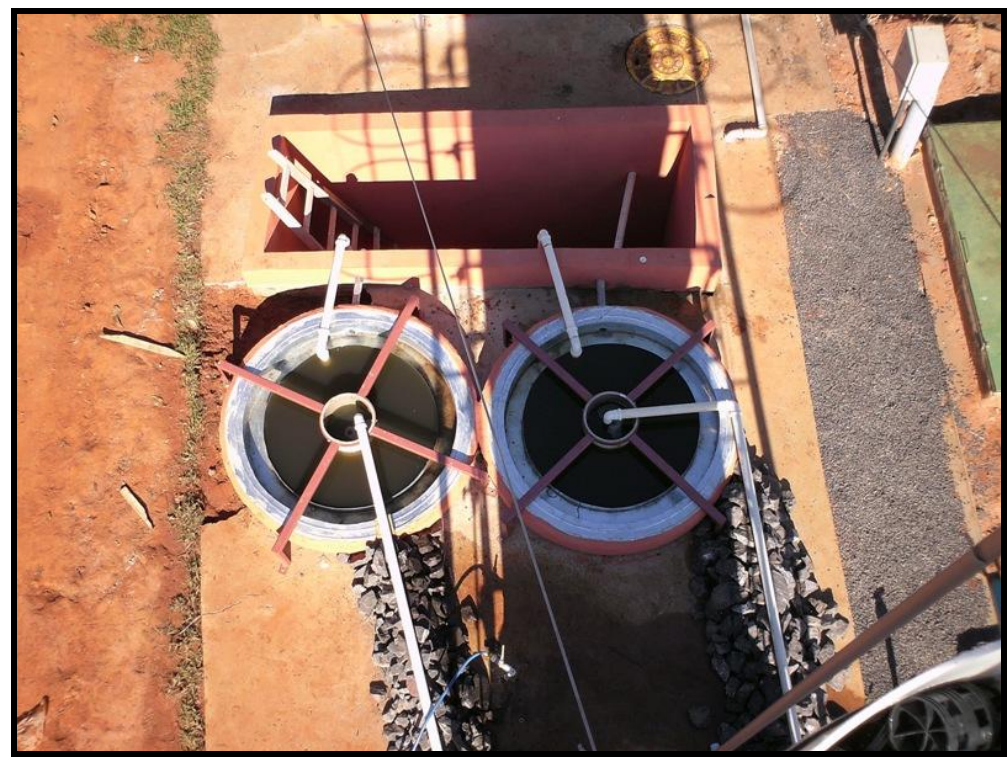

Figura 4.11: Decantadores secundários do FBP 
VEM DO FILTRO BIOLOGICO

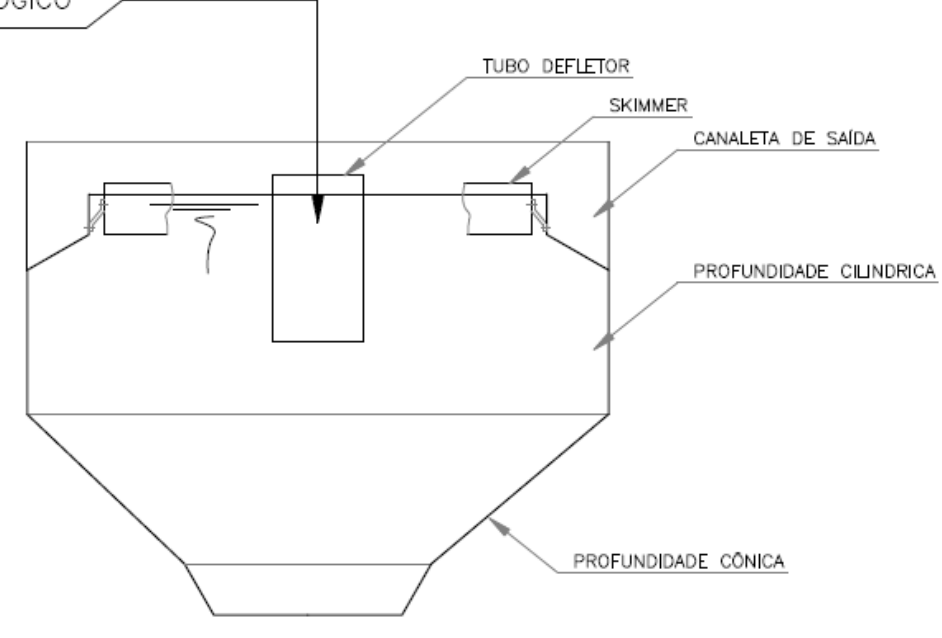

DECANTADOR BIOLOGICO

DIMENSOES
DIAN.: $1.0 \mathrm{~m} \times$ PROF. UTL: $2.50 \mathrm{~m}$
PROF. CONICA: $0,80 \mathrm{~m}$

Figura 4.12: Detalhes construtivos dos decantadores

\subsection{Etapas experimentais e condições operacionais}

O desempenho do sistema Lagoas/FBP foi avaliado em quatro etapas operacionais. Os filtros foram projetados para trabalharem com uma taxa de aplicação superficial variando entre baixa, intermediária e alta.

Optou-se iniciar a operação com taxa baixa, com vazões menores, aumentando-as até o ponto onde foi verificado que o processo de nitrificação cessou, este foi o critério escolhido para encerrarmos as atividades no filtro. A duração de cada etapa operacional foi de aproximadamente 180 dias. 0 estabelecimento deste período levou em conta a quantidade de dados necessários para uma análise estatística consistente. Entretanto, na última fase as taxas foram alteradas semanalmente até que o critério de parada fosse atendido.

A tabela 4.2 apresenta as condições operacionais utilizadas na pesquisa. 
Tabela 4.2: Condições operacionais aplicadas aos FBPs

\begin{tabular}{|c|c|c|c|c|c|c|}
\hline \multirow{2}{*}{\multicolumn{3}{|c|}{ Variáveis }} & \multicolumn{4}{|c|}{ Fases } \\
\hline & & & \multirow{2}{*}{$\frac{\mathbf{1}}{4,24}$} & \multirow{2}{*}{$\begin{array}{c}\mathbf{2} \\
6,37\end{array}$} & \multirow{2}{*}{$\begin{array}{c}3 \\
8,49\end{array}$} & \multirow{2}{*}{$\frac{\mathbf{4}}{10,61}$} \\
\hline & TES & $\left(m^{3} / m^{2} . d\right)$ & & & & \\
\hline & $\mathbf{Q}$ & $\left(m^{3} / d\right)$ & 2,40 & 3,60 & 4,80 & 6,00 \\
\hline & $\mathbf{Q}$ & $(\mathrm{L} / \mathrm{h})$ & 100 & 150 & 200 & 250 \\
\hline \multirow{4}{*}{ NKT } & C & $(\mathrm{Kg} \mathrm{N} / \mathrm{d})$ & 0,12 & 0,18 & 0,24 & 0,30 \\
\hline & TAV & $\left(\mathrm{Kg} \mathrm{N} / \mathrm{m}^{3} . \mathrm{d}\right)$ & 0,053 & 0,080 & 0,106 & 0,133 \\
\hline & & $\left(\mathrm{g} \mathrm{N} / \mathrm{m}^{2} . \mathrm{d}\right)$ & 0,76 & 1,14 & 1,52 & 1,90 \\
\hline & TAS plastico & $\left(\mathrm{g} \mathrm{N} / \mathrm{m}^{2} . \mathrm{d}\right)$ & 0,53 & 0,80 & 1,06 & 1,33 \\
\hline \multirow{4}{*}{ DBO } & C & $(\mathrm{Kg} \mathrm{DBO} / \mathrm{d})$ & 0,13 & 0,20 & 0,27 & 0,34 \\
\hline & TAV & $\left(\mathrm{Kg} \mathrm{DBO} / \mathrm{m}^{3} \cdot \mathrm{d}\right)$ & 0,06 & 0,09 & 0,12 & 0,15 \\
\hline & TAS brita & $\left(g \mathrm{DBO} / \mathrm{m}^{2} . \mathrm{d}\right)$ & 0,85 & 1,27 & 1,70 & 2,12 \\
\hline & TAS plastico & $\left(\mathrm{g} \mathrm{DBO} / \mathrm{m}^{2} . \mathrm{d}\right)$ & 0,59 & 0,89 & 1,19 & 1,49 \\
\hline \multirow{4}{*}{ DQO } & C & (Kg DQO/d) & 0,57 & 0,86 & 1,14 & 1,43 \\
\hline & TAV & $\left(\mathrm{Kg} \mathrm{DQO} / \mathrm{m}^{3} . \mathrm{d}\right)$ & 0,25 & 0,38 & 0,51 & 0,63 \\
\hline & TAS brita & $\left(\mathrm{g} D Q O / \mathrm{m}^{2} . \mathrm{d}\right)$ & 3,61 & 5,42 & 7,22 & 9,03 \\
\hline & TAS plastico & $\left(\mathrm{g} D Q O / \mathrm{m}^{2} . \mathrm{d}\right)$ & 2,53 & 3,79 & 5,05 & 6,32 \\
\hline
\end{tabular}

A tabela mostrada acima foi elaborada considerando os valores abaixo ( valores efluentes da lagoa facultativa):

- $\mathrm{NTK}=50 \mathrm{mg} \mathrm{N} / \mathrm{L}$;

- $\mathrm{DBO}=56 \mathrm{mg} \mathrm{O}_{2} / \mathrm{L}$;

- $\mathrm{DQO}=238 \mathrm{mg} \mathrm{O}_{2} / \mathrm{L}$;

- Volume útil de cada filtro= 2,26 $\mathrm{m}^{3}$;

- Área superficial de cada filtro= $0,56 \mathrm{~m}^{2}$;

- Área específica Brita $=70 \mathrm{~m}^{2} / \mathrm{m}^{3}$;

- Área específica Aneis Plásticos $=100 \mathrm{~m}^{2} / \mathrm{m}^{3}$.

\subsection{Análises físico-químicas e técnicas analíticas}

As análises físico-químicas foram feitas em dois laboratórios diferentes, o Laboratório de Saneamento da Poli-USP e no Laboratório de Química da Unilins. 
As análises de controle, tais como: oxigênio dissolvido (OD), temperatura, alcalinidade, pH, Amônia, Nitrogênio Total Kjeldhal, nitrito e nitrato foram realizadas no laboratório de química - Unilins, com a intenção de manter a integridade das amostras; as demais análises tais como: sólidos, DBO (total e filtrada) e DQO (total e filtrada), foram realizadas na Escola Politécnica em São Paulo.

Foram coletadas amostras das operações unitárias do tratamento, contemplando o afluente da estação (efluente bruto), lagoa anaeróbia, lagoa facultativa e os filtros biológicos. Não foram realizadas coletas após os decantadores, pois não era objetivo verificar a eficiência com relação à remoção de sólidos, focando o trabalho nas concentrações de nitrogênio na saída dos filtros biológicos.

As amostras foram coletadas sempre no mesmo horário, por volta de $14 \mathrm{~h}$ e rapidamente eram conduzidas ao laboratório. A técnica utilizada para coleta das amostras foi amostragem simples e foram também coletadas amostras simples de pontos intermediários do filtro. Esses pontos estavam distribuidos ao longo da altura do filtro e somavam para cada filtro um total de sete pontos.

A figura 4.13 apresenta um corte esquemático do filtro, onde é possível observar os pontos intermediários. 


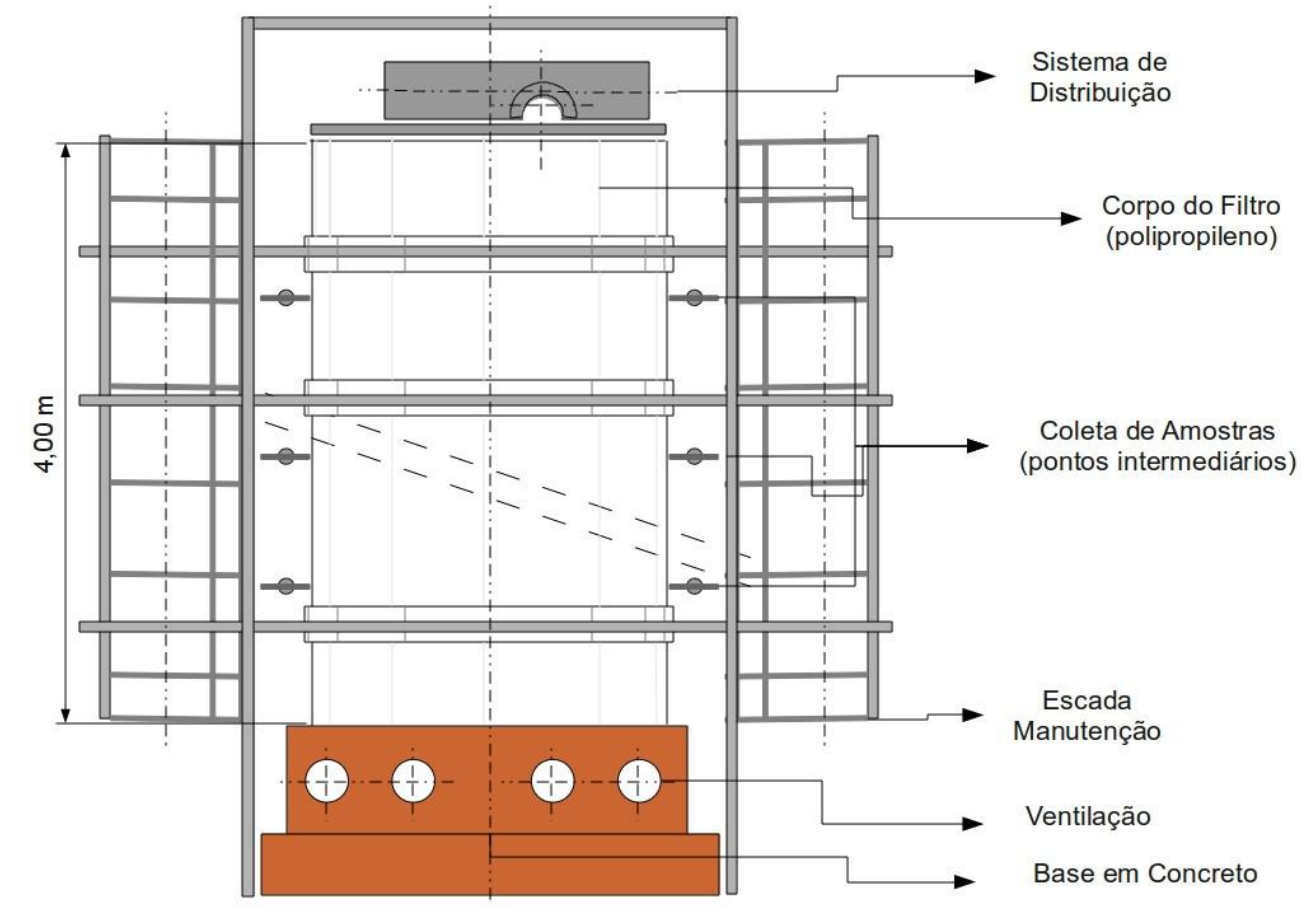

Figura 4.13: Corte esquemático dos FBPs

O esgoto bruto, os efluentes da Lagoa Anaeróbia, da Facultativa, do Filtro de Pedra e o do Filtro de Plástico foram submetidos a uma série de analises, coletando-se amostras simples para as determinações de:

- $\mathrm{pH}, 2$ vezes por semana;

- Temperatura, 2 vezes por semana;

- Oxigênio dissolvido, 2 vezes por semana;

- Nitrogênio Total Kjedhal; 2 vezes por semana;

- Nitrogênio Amoniacal; 2 vezes por semana;

- Nitrito, 2 vezes por semana;

- Nitrato, 2 vezes por semana;

- Alcalinidade total, semanalmente;

- Demanda Bioquímica de Oxigênio, $\mathrm{DBO}_{5,20}$ total, semanalmente;

- Demanda Química de Oxigênio, semanalmente;

- Clorofila a, semanalmente;

- Série de sólidos, semanalmente;

- Coliformes Totais e E. Coli, quinzenalmente;

- Ovos de Helmintos, quinzenalmente; 
Para os pontos intermediários, as análises realizadas tiveram como objetivo determinar as concentrações de nitrogênio amoniacal, nitrito e nitrato.

Os parâmetros foram determinados de acordo com o Standard Methods for Examination Water and Wastewater - AWWA, 20 th edition, 2000, United States Environmental Protection Agency e Normas Técnicas da CETESB através das metodologias descritas na Tabela 4 ..

Tabela 4.3: Metodologias utilizadas para determinação de cada parâmetro

\begin{tabular}{|c|c|c|}
\hline PARÂMETRO & METODOLOGIA & DESCRIÇÃO \\
\hline $\mathrm{pH}$ & $\begin{array}{l}4500-\mathrm{H}+\mathrm{B} \\
\text { Standard Methods }\end{array}$ & Método eletrométrico. $\mathrm{pH}$ metro da \\
\hline Alcalinidade & $\begin{array}{l}2320 \mathrm{~B} \\
\text { Standard Methods }\end{array}$ & $\begin{array}{l}\text { Método titulométrico através da } \\
\text { adição de Ácido Sulfúrico } 0,02 \mathrm{~N}\end{array}$ \\
\hline $\begin{array}{l}\mathrm{DBO}_{5} \mathrm{e} \\
\mathrm{DBO}_{5} \text { filtrada }\end{array}$ & $\begin{array}{l}5200 \text { B } \\
\text { Standard Methods }\end{array}$ & $\begin{array}{l}\text { Diluição e incubação por } 5 \text { dias a } \\
20^{\circ} \mathrm{C} \text {, com determinação dos níveis } \\
\text { iniciais e finais de oxigênio atreves do } \\
\text { método da Azida modificado }\end{array}$ \\
\hline $\begin{array}{l}\text { DQO e } \\
\text { DQO filtrada }\end{array}$ & $\begin{array}{l}5220 \text { D } \\
\text { Standard Methods }\end{array}$ & $\begin{array}{l}\text { Método do refluxo fechado. Digestão } \\
\text { com dicromato de potássio em meio } \\
\text { ácido e leitura em espectrofotômetro } \\
\text { Aquamate da MERCK }\end{array}$ \\
\hline NKT & $\begin{array}{l}4500 \text { - } N_{\text {org }} \\
\text { Standard Methods }\end{array}$ & $\begin{array}{l}\text { Digestão química da amostra e } \\
\text { titulação da amônia destilada com } \\
\text { Ácido Sulfúrico } 0,02 \mathrm{~N}\end{array}$ \\
\hline $\mathrm{N}-\mathrm{NH}_{3}$ & $\begin{array}{l}4500-\mathrm{N}-\mathrm{NH}_{3} \mathrm{E} \\
\text { Standard Methods }\end{array}$ & $\begin{array}{l}\text { Destilação da amostra tamponada a } \\
\text { um pH } 9,5 \text {, na qual o destilado é } \\
\text { coletado em uma solução de ácido } \\
\text { bórico e em seguida titulado com } \\
\text { Ácido Sulfúrico } 0,02 \mathrm{~N}\end{array}$ \\
\hline Clorofila A & $\begin{array}{l}10200 \mathrm{H} \\
\text { Standard Methods }\end{array}$ & $\begin{array}{l}\text { Filtração a vácuo da amostra, } \\
\text { extração da clorofila através da } \\
\text { adição de Acetona }+\mathrm{MgCO}_{3} \text { e leitura } \\
\text { em espectrofotômetro Aquamate da } \\
\text { MERCK }\end{array}$ \\
\hline ST & $\begin{array}{l}2540 \text { B } \\
\text { Standard Methods }\end{array}$ & $\begin{array}{l}\text { Método gravimétrico. Secagem em } \\
\text { estufa a } 105^{\circ} \mathrm{C}\end{array}$ \\
\hline SST & $\begin{array}{l}2540 \text { D } \\
\text { Standard Methods }\end{array}$ & $\begin{array}{l}\text { Método gravimétrico. Filtração a } \\
\text { vácuo em membrana GFC } 1,2 \square \mathrm{m} \text { e } \\
\text { secagem em estufa a } 105^{\circ} \mathrm{C}\end{array}$ \\
\hline $\begin{array}{l}\text { SF, SV, SSF } \\
\text { e SSV }\end{array}$ & $\begin{array}{l}2540 \mathrm{E} \\
\text { Standard Methods }\end{array}$ & Calcinação em forno mufla a $550^{\circ} \mathrm{C}$ \\
\hline
\end{tabular}




\section{RESULTADOS E DISCUSSÃo}

\subsection{Resultados apresentados por ETAPA}

\subsubsection{Filtros percoladores em escala piloto - ETAPA 01}

Os dois filtros percoladores em escala piloto entraram em operação em 18/06/2007, recebendo o efluente da lagoa facultativa, inciando sob carga volumétrica de $0,058 \mathrm{kgNKT} / \mathrm{m}^{3}$.d e Taxa de aplicação hidráulica superficial de $4,2 \mathrm{~m} / \mathrm{m}^{2}$.d, após período de adaptação de cerca de 100 dias. As Figuras $5.1 \mathrm{e}$ 5.2 apresentam as condições operacionais impostas aos filtros biológicos na etapa 01.
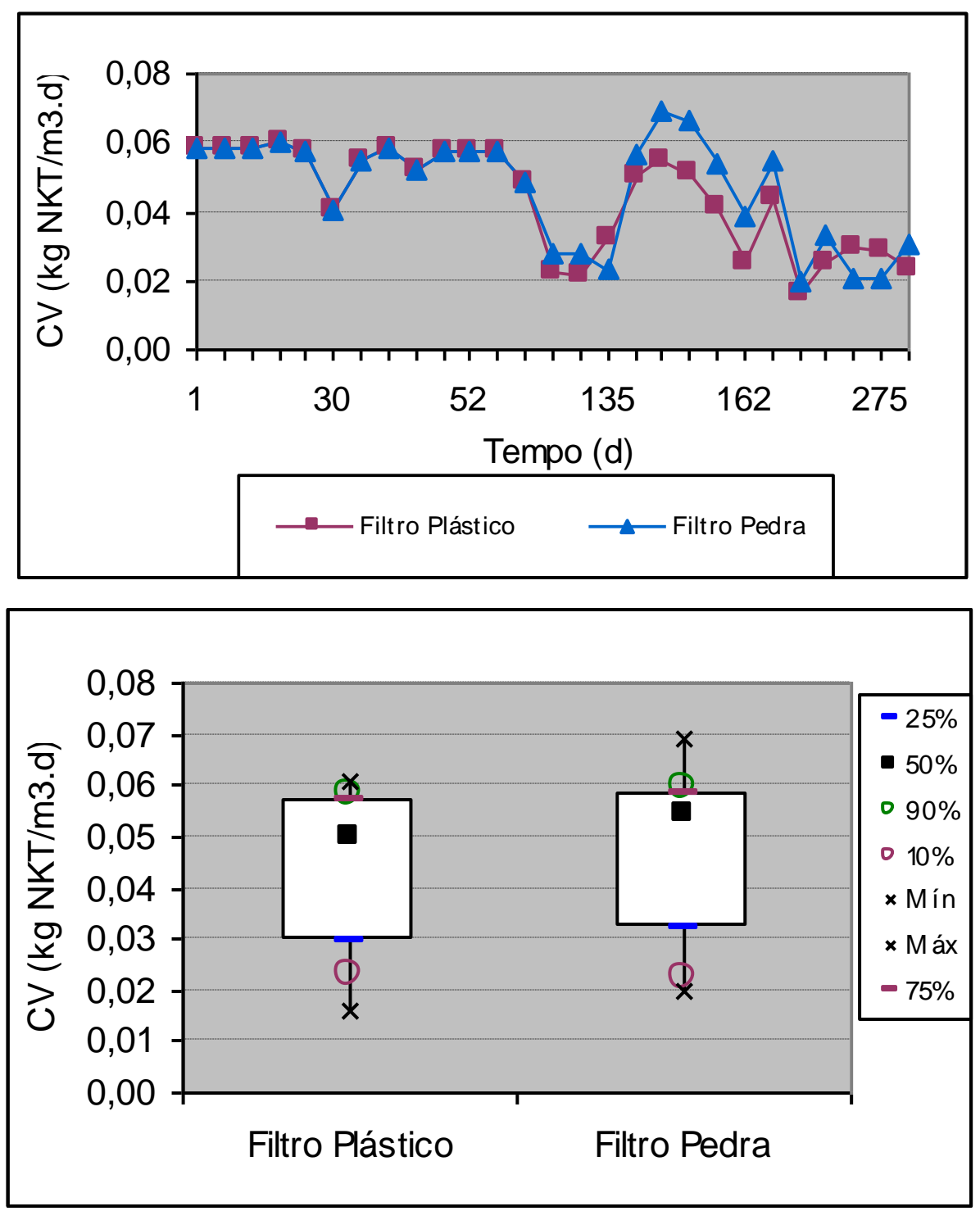
Figura 5.1: Carga volumétrica de NKT - ETAPA 01
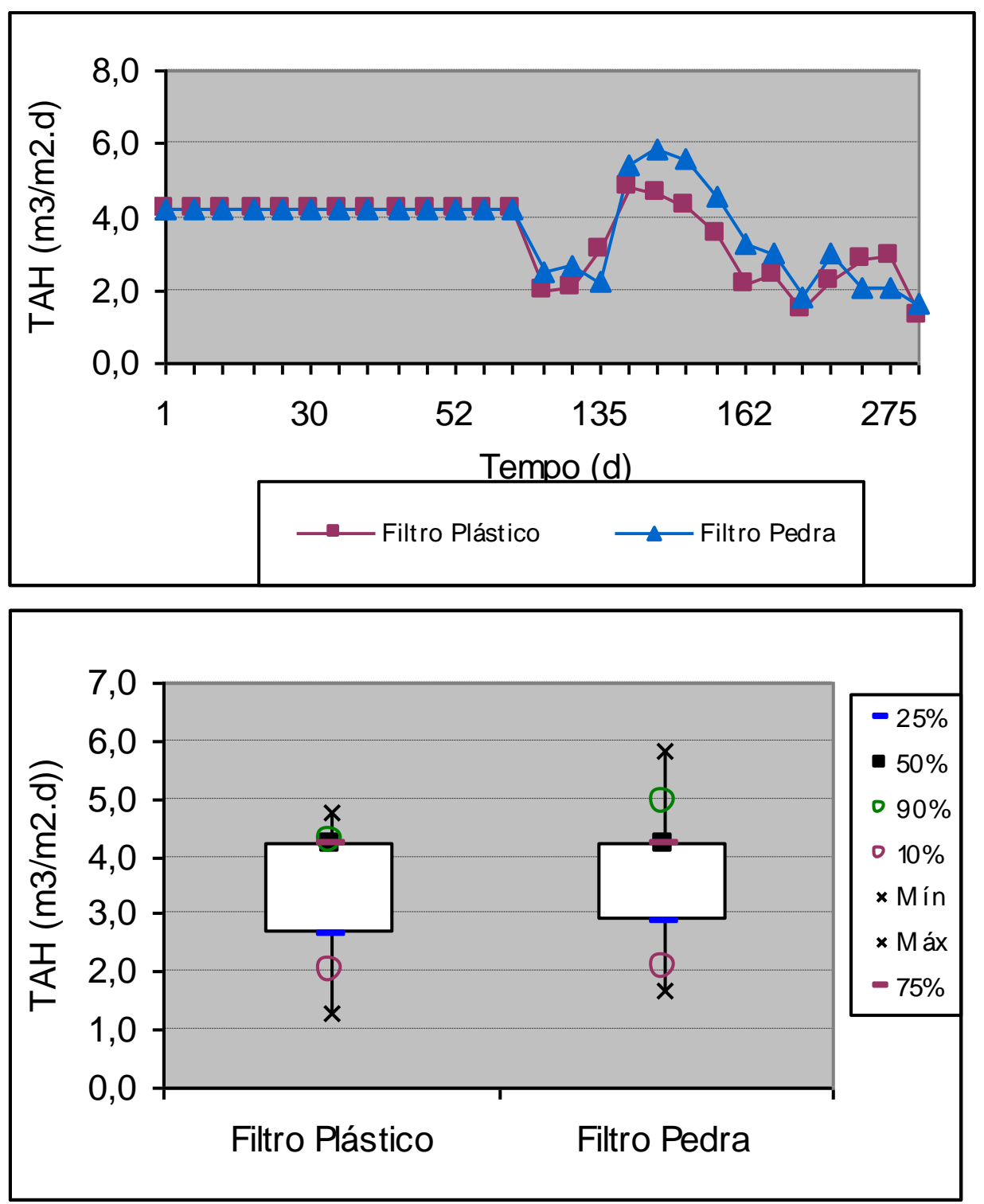

Figura 5.2: Taxa de aplicação hidráulica superficial nos filtros - ETAPA 01

Observa-se que não houve diferenças significativas entre as taxas superficiais aplicadas no filtro com leito de pedra e plástico e cerca de $50 \%$ dos valores ficaram com taxas de $4,2 \mathrm{~m}^{3} / \mathrm{m}^{2} . \mathrm{d}$ em ambos os filtros, submetendo-os a operarem como filtros de taxa intermediária. A carga volumétrica de nitrogênio Total Kjeldahl teve como mediana os valores de $0,05 \mathrm{kgNKT} / \mathrm{m}^{3}$.d para ambos os filtros. 


\subsubsection{Eficiência de molhamento dos meios suporte - ETAPA 01}

De acordo com a revisão bibliográfica, a elevada superfície específica dos meios suportes pode não ser totalmente umedecida quando aplicadas reduzidas taxas de aplicação hidráulicas superficiais. Os cálculos de eficiência de molhamento da ETAPA 01 são apresentados a seguir:

- Eficiência de molham ento na Etapa 1 - Filtro Plástico

$\operatorname{Ef}(\%)=\mathrm{TAH} /\left[\mathrm{TAH}+\left(\check{\Gamma} \times \mathrm{As}_{s}\right)\right]=4,2 /[4,2+(0,113 \times 100)]=27 \%$

- Eficiência de molham ento na Etapa 1 - Filtro Pedra

$\operatorname{Ef}(\%)=\mathrm{TAH} /\left[\mathrm{TAH}+\left(\check{\Gamma} \times \mathrm{As}_{\mathrm{s}}\right)\right]=4,2 /[4,2+(0,113 \times 70)]=35 \%$

Os cálculos apresentados acima demonstram que a taxa de aplicação hidráulica superficial utilizada na Etapa 01 não foram suficientes para promover o molhamento eficiente de toda a superfície de meio suporte, permitindo o molhamento de apenas $27 \%$ e $35 \%$ da superfície total dos filtros de Plástico e Pedra, respectivamente.

\subsubsection{Parâmetros de controle - ETAPA 01}

As Figuras 5.3 a 5.6 apresentam uma estatística dos parâmetros de controle, como $\mathrm{pH}$, temperatura, alcalinidade e concentração de oxigênio dissolvido dos efluentes.

Durante a Etapa 01, observou-se que a mediana dos resultados de $\mathrm{pH}$ monitorados nos efluentes dos filtros e pedra e de plástico estiveram em 7,9, enquanto que 0 afluente apresentou valores de 7,6, verificando-se um ligeiro aumento do $\mathrm{pH}$ no efluente. 


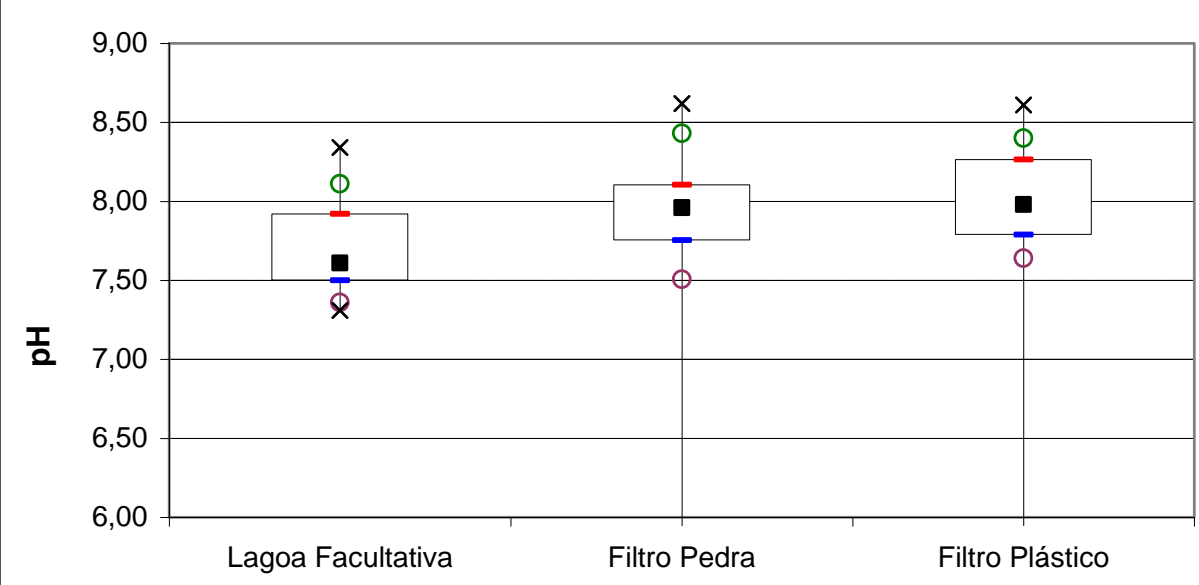
$-25 \%$
- $50 \%$
$090 \%$
$010 \%$
× Mín
× Máx
$-75 \%$

Figura 5.3: pH afluente e efluente dos filtros percoladores em escala piloto ETAPA 01

Em relação à temperatura, houve queda de $1^{\circ} \mathrm{C}$ do efluente nos filtros em relação ao afluente, mantendo-se na faixa de $24^{\circ} \mathrm{C}$. A temperatura do ar se manteve praticamente constante, na faixa de $28^{\circ} \mathrm{C}$.

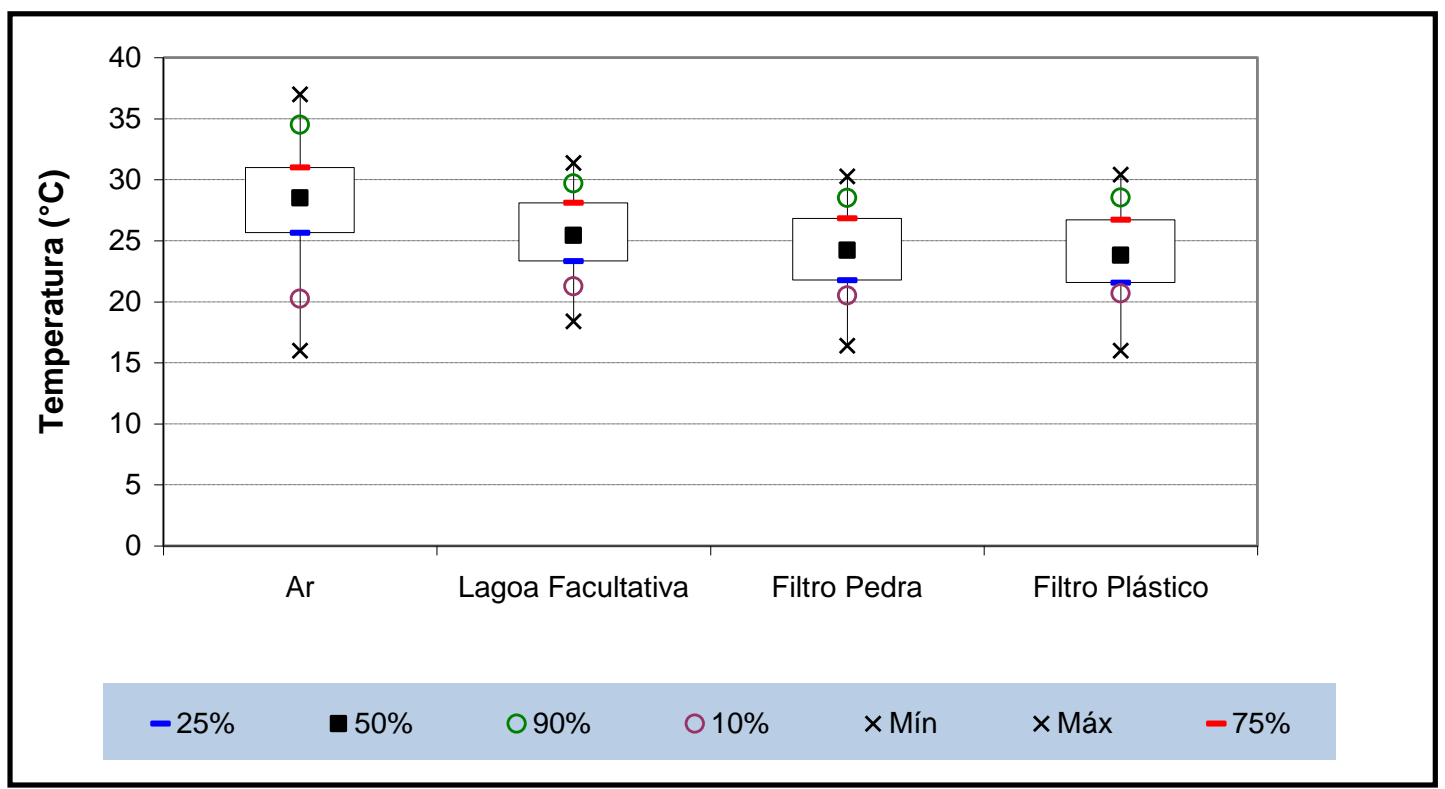

Figura 5.4: Temperatura afluente e efluente dos filtros percoladores em escala piloto - ETAPA 01 
Quanto à alcalinidade, $50 \%$ dos valores obtidos no filtro de pedra estiveram na ordem de $184 \mathrm{mg} / \mathrm{L}$, enquanto que no filtro de plástico, a alcalinidade esteve em $252 \mathrm{mg} / \mathrm{L}$. Tais resultados foram inferiores ao verificado no afluente, o qual se apresentou com $392 \mathrm{mg} / \mathrm{L}$. Como a queda de alcalinidade está associada à nitrificação, pode-se dizer que houve maior grau de nitrificação no filtro preenchido com brita, conforme será verificado na análise das séries nitrogenadas no subitem 5 .1.1.3 - Formas Nitrogenadas - ETAPA 1.

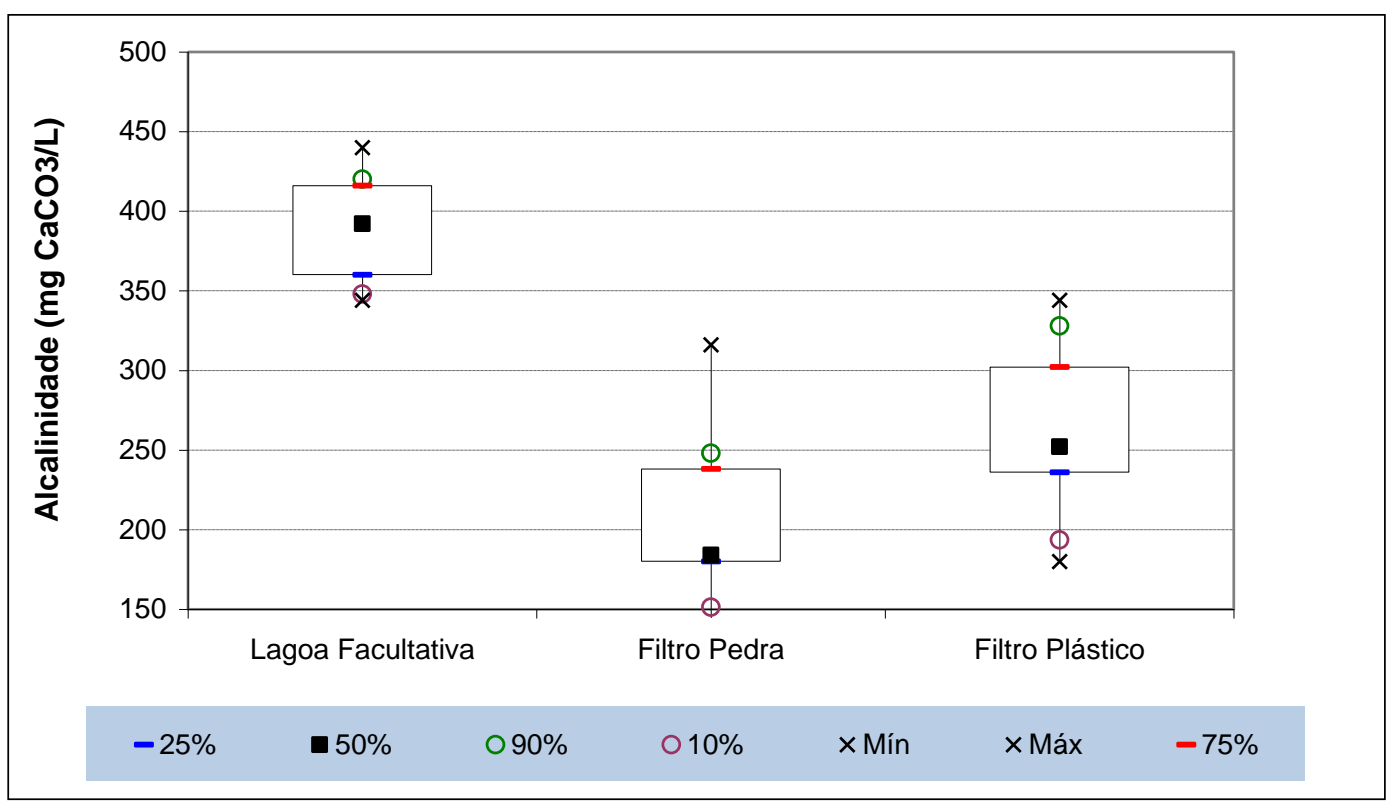

Figura 5.5: Alcalinidade afluente e efluente dos filtros percoladores em escala piloto - ETAPA 01

De acordo com a figura 5.6, verifica-se que a concentração de oxigênio nos filtros se manteve em 6,2 mg/l conforme mediana das amostras monitoradas, valores suficientes para garantir a nitrificação, não sendo considerado fator limitante, uma vez que a literatura recomenda mínimo de $2 \mathrm{mg} / \mathrm{l}$. O afluente do filtro biológico manteve $50 \%$ dos valores em $0,90 \mathrm{mg} / \mathrm{L}$, o que demonstra a boa oxigenação do efluente nos filtros percoladores. 


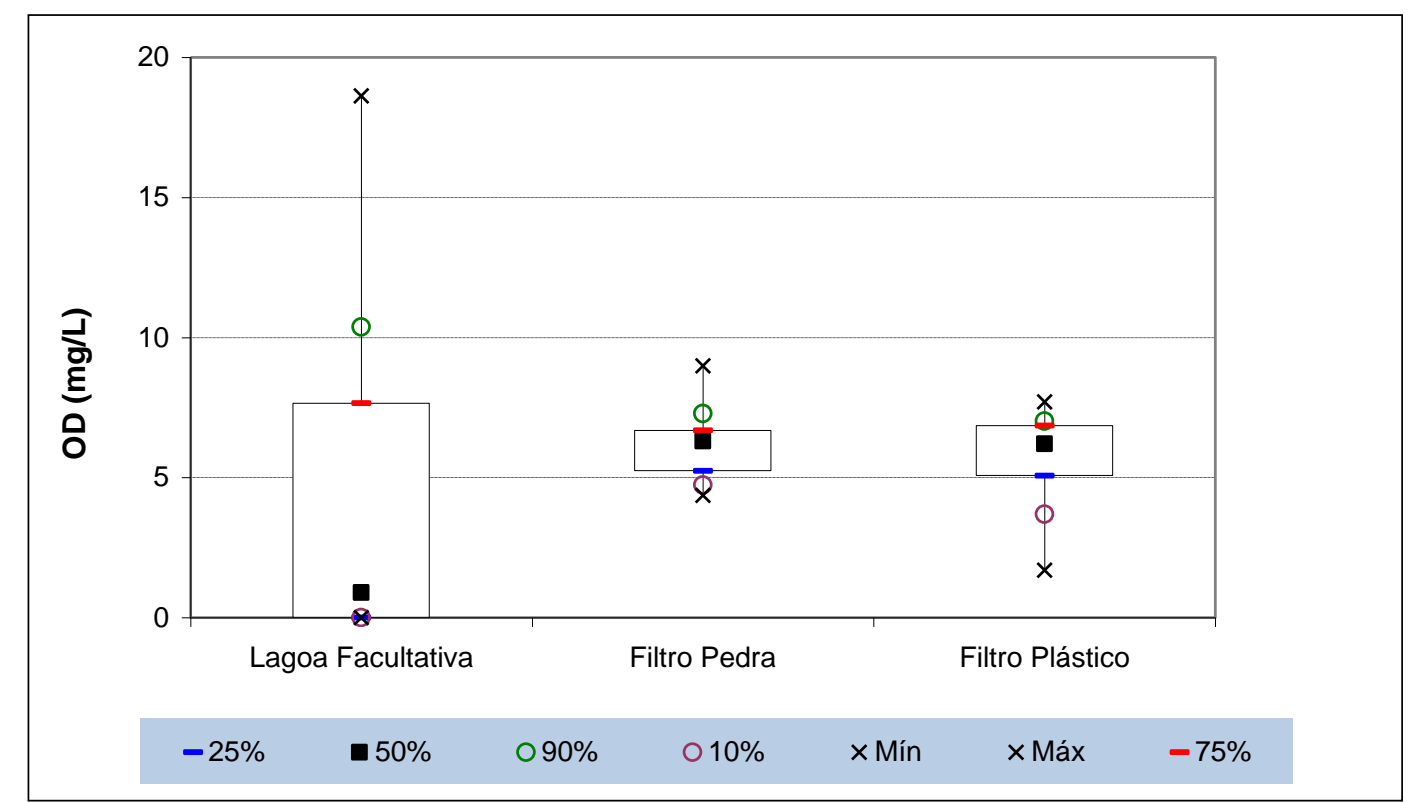

Figura 5.6: Concentração de oxigênio dissolvido afluente e efluente dos filtros percoladores em escala piloto - ETAPA 01

\subsubsection{Formas nitrogenadas - ETAPA 01}

As Figuras 5.7, 5.8, 5.9 e 5.10 apresentam a estatística básica das formas nitrogenadas.

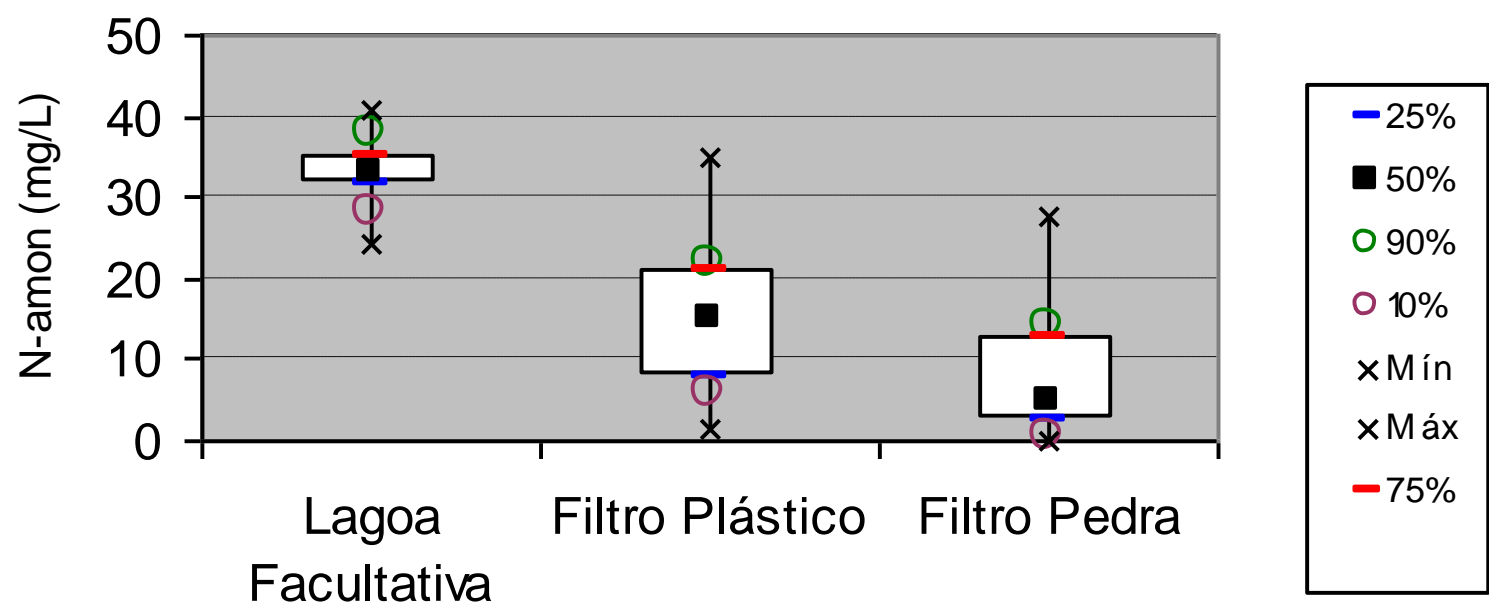




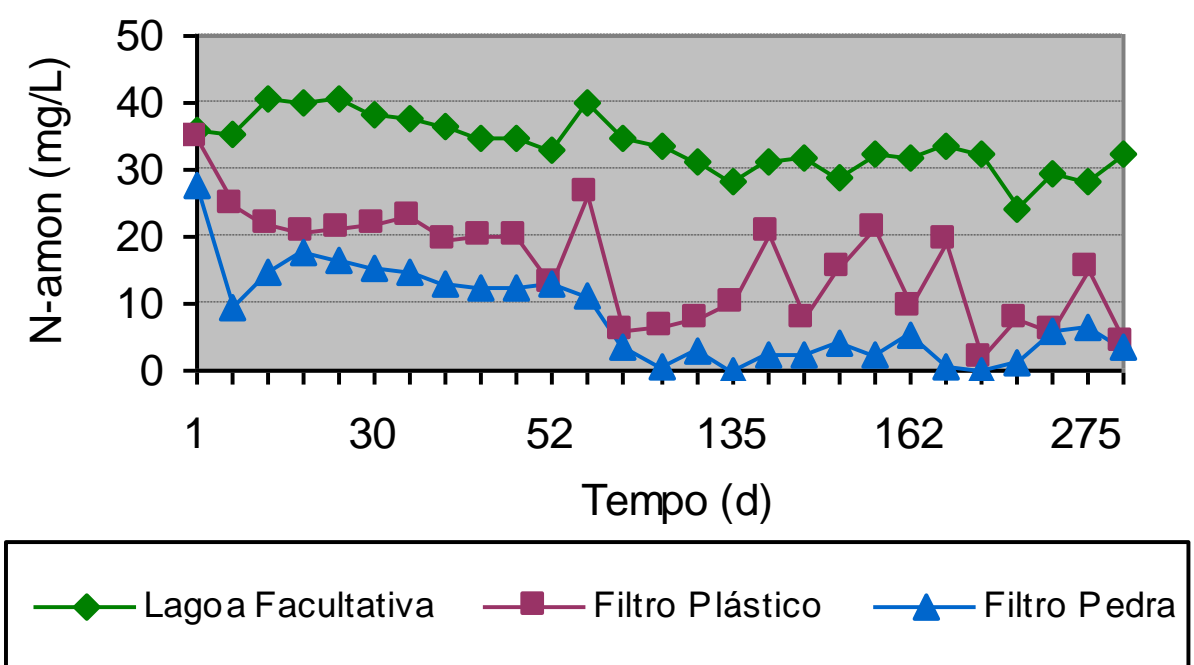

Figura 5.7: Diagrama box-whisker e série histórica de nitrogênio amoniacal ETAPA 01

A remoção do nitrogênio amoniacal foi mais significativo no filtro preenchido com brita, uma vez ter apresentado em seu efluente final concentração em média de $5 \mathrm{mg} / \mathrm{l}$, enquanto que no filtro com anéis de plástico, a concentração esteve em aproximadamente $15 \mathrm{mg} / \mathrm{l}$. Apesar da menor área superficial, a rugosidade das britas facilita a formação do biofilme, fator que pode ter sido determinante para a maior eficiência verificada neste filtro, conforme demonstrado pela figura 5.9. 


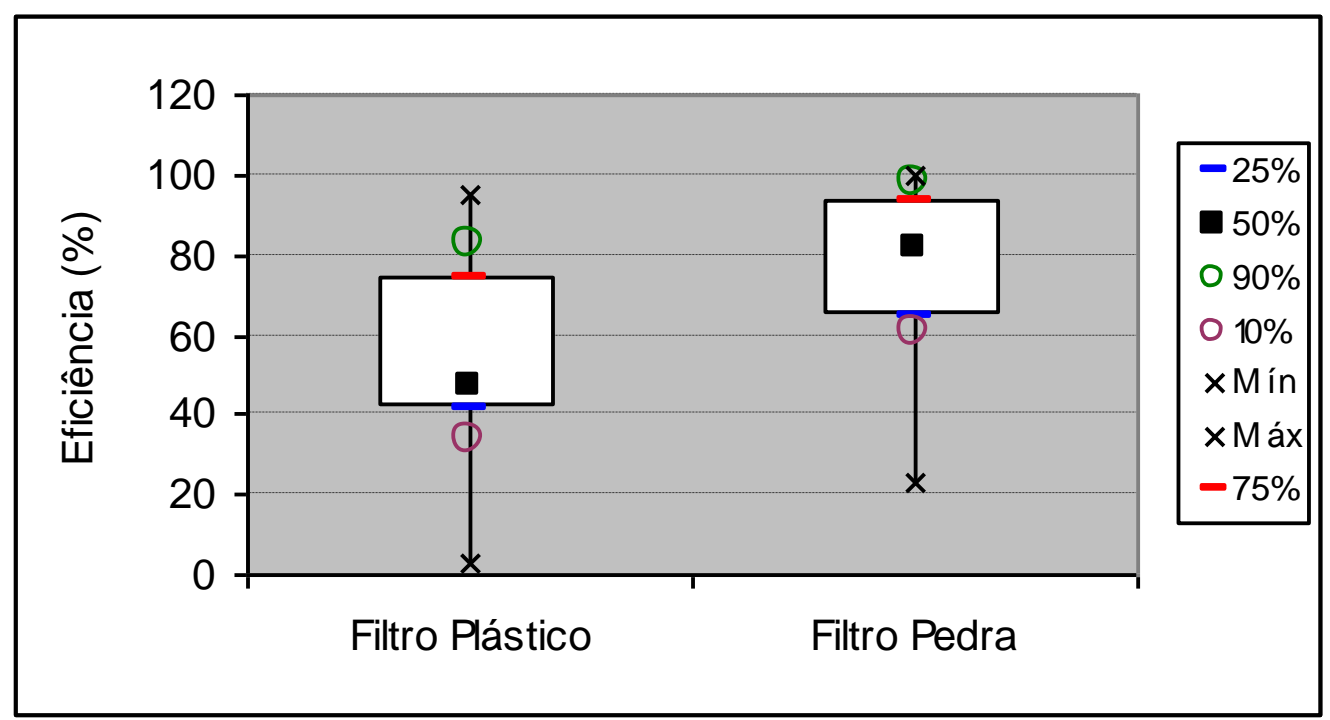

Figura 5.8: Características estatísticas da concentração de nitrogênio amoniacal dos filtros percoladores em escala piloto - ETAPA 01

Em relação ao nitrito, verifica-se pelas figuras 5.10 e 5.11 que houve aumento significativo na sua concentração no filtro preenchido com anéis de plástico, sendo este valor bastante superior ao verificado no filtro com brita. Esta diferença pode ser característica do acúmulo de nitrito no efluente, causado pelo excesso de nitrogênio amoniacal ou outra interferência ambiental. 

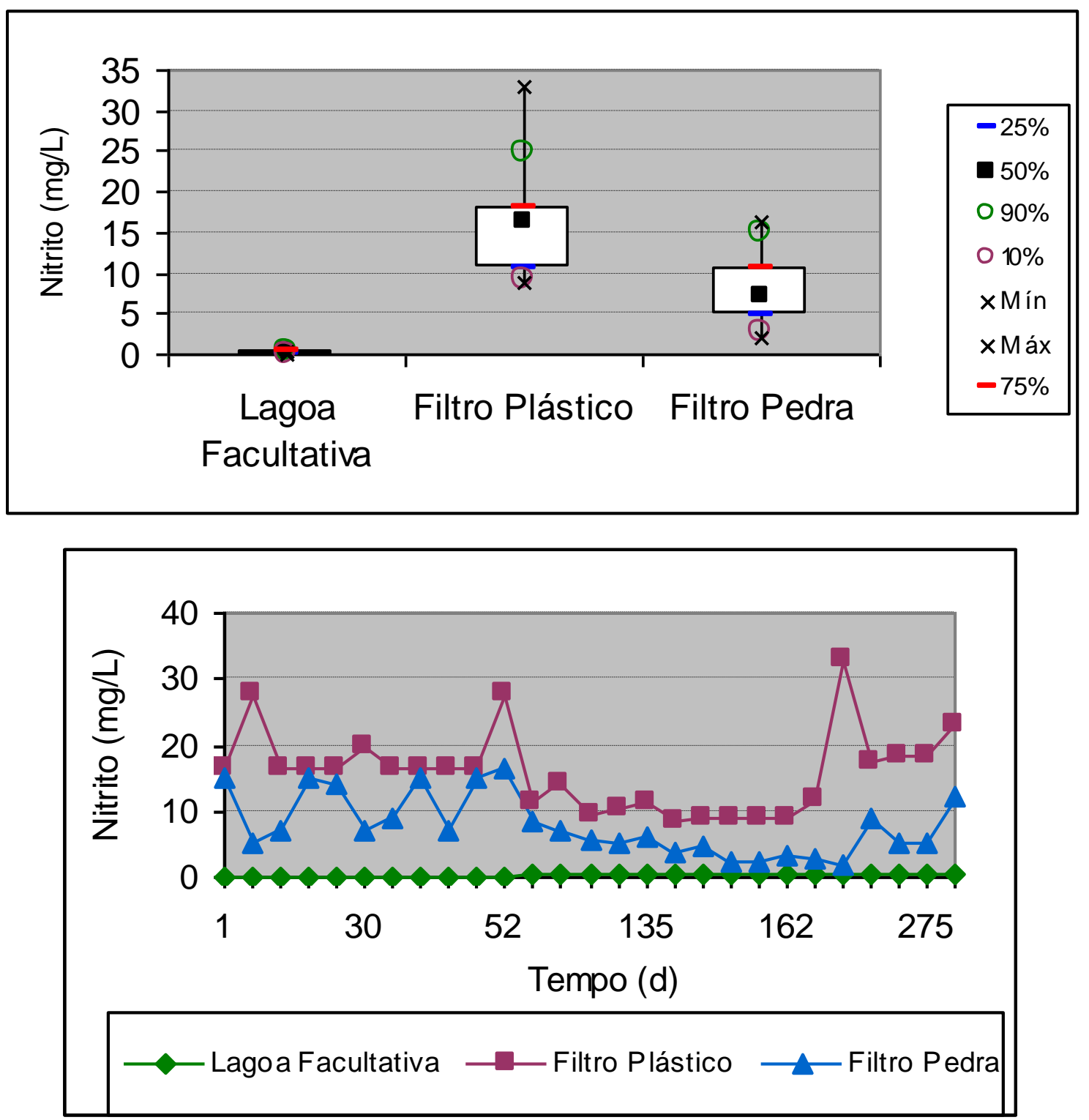

Figura 5.9: Diagrama box-whisker e série histórica de nitrito - ETAPA 01

O acúmulo de nitrito ocorrido no filtro preenchido com anéis de plástico pode ser verificado pela baixíssima concentração de nitrato em seu efluente final, diferentemente da concentração de nitrato apresentado no efluente do filtro de brita, fato comprobatório do processo de nitrificação. 

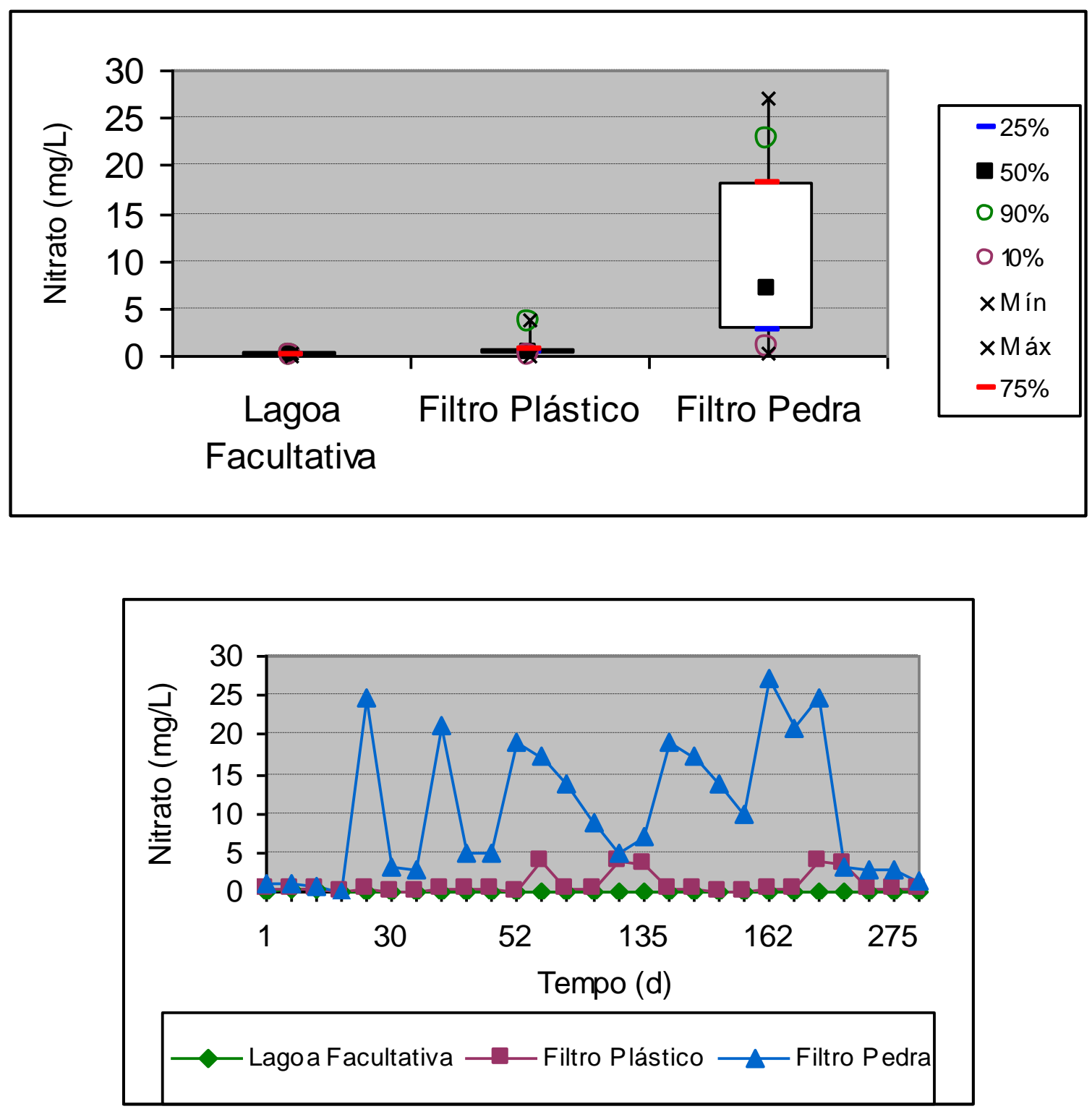

Figura 5.10: Diagrama box-whisker e série histórica de nitrato - ETAPA 01

Nas condições impostas nesta primeira etapa, ambos filtros apresentaram condições de reduzir as concentrações de nitrogênio amoniacal para valores abaixo de $20 \mathrm{mg} / \mathrm{L}$, podendo-se alcançar eficiência na remoção de até $80 \%$ no filtro com leito de pedra. A evolução do filtro preenchido com brita ocorreu de forma mais rápida, possivelmente pela área superficial rugosa, o que facilita a formação do biofilme e consequentemente a nitrificação praticamente completa nos efluentes. Embora o anel plástico ofereça uma área superficial específica maior, o efeito de área superficial lisa impossibilitou a rápida formação da biomassa aderida, obtendo assim eficiência de aproximadamente $50 \%$. No filtro 
preenchido com anéis plásticos, ocorreu acúmulo de nitrito e baixa formação de nitrato, não ocorrendo a etapa completa da nitrificação.

\subsubsection{DQO, DBO e SST - ETAPA 01}

As Figuras 5.11 e 5.12 ilustram respectivamente as séries históricas das concentrações de DQO, DBO e SST da Lagoa Facultativa e do efluente dos Filtros de Plástico e Pedra, e a tabela 5.1 demonstra a estatística descritiva dos referidos parâmetros.
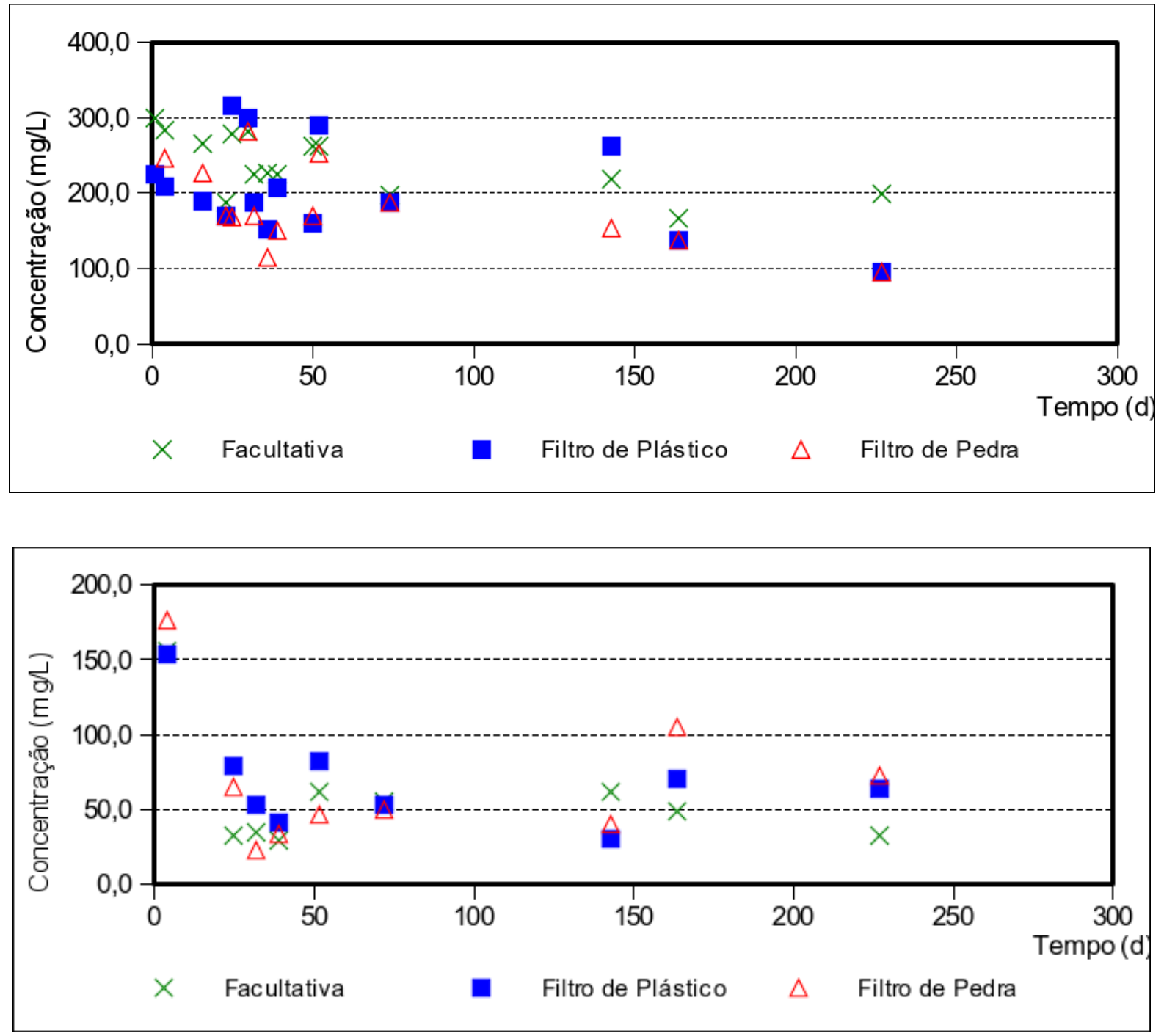

Figura 5.11: Gráfico de dispersão da concentração de DQO e DBO dos efluentes - ETAPA 01 


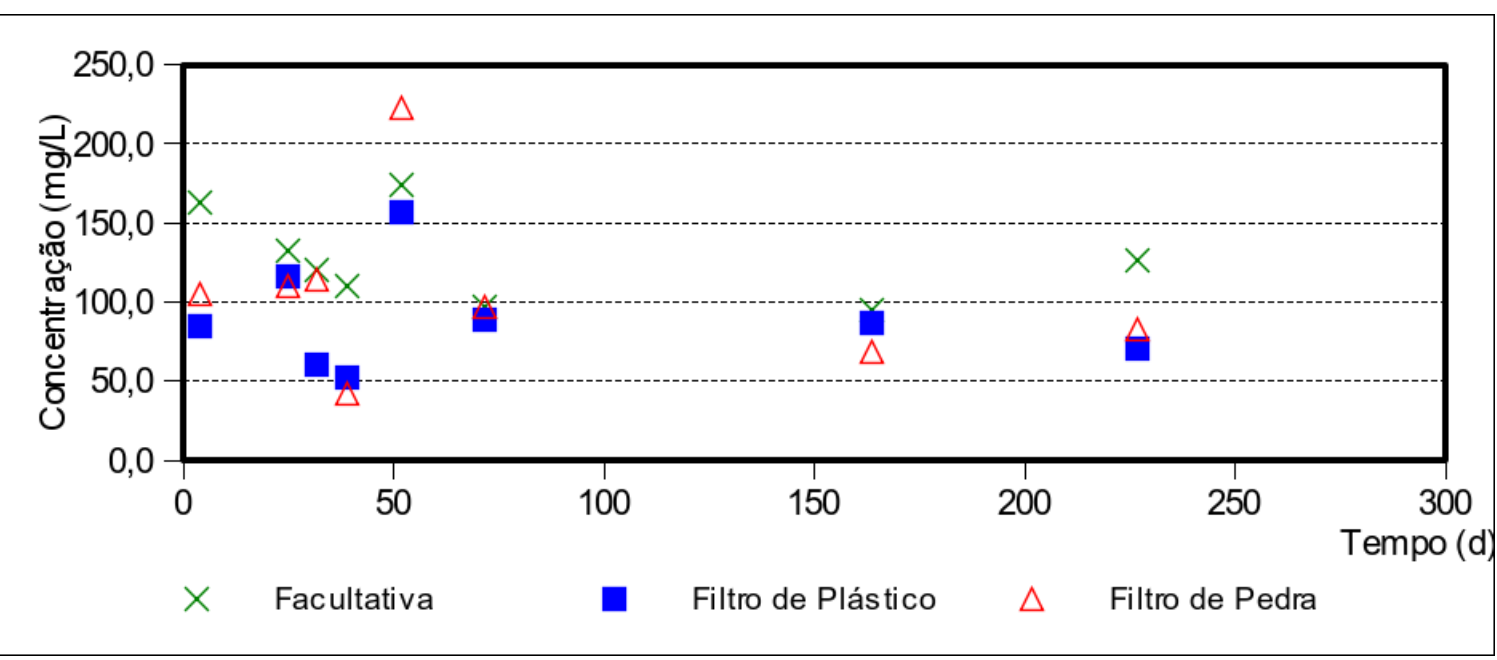

Figura 5.12: Gráfico de dispersão da concentração de sólidos em suspensão totais - ETAPA 01

Tabela 5.1: Estatística descritiva dos valores medianos de DQO, DBO e SST ETAPA 01

\begin{tabular}{|l|l|c|c|c|}
\hline & & $\mathrm{DQO}(\mathrm{mg} / \mathrm{L})$ & $\mathrm{DBO}(\mathrm{mg} / \mathrm{L})$ & $\mathrm{SST}(\mathrm{mg} / \mathrm{L})$ \\
\hline \multirow{3}{*}{ Etapa 01 } & Lagoa Facultativa & 230 & 40 & 120 \\
\cline { 2 - 5 } & Filtro Plástico & 180 & 60 & 80 \\
\cline { 2 - 5 } & Filtro Pedra & 160 & 50 & 100 \\
\hline
\end{tabular}

Observa-se que não ocorre remoção adicional considerável de matéria orgânica nos filtros, demonstrando que a constituição do biofilme é essencialmente voltada à presença de nitrobactérias. Ao contrário, o ligeiro aumento na concentração de matéria orgânica é proveniente do desprendimento da biomassa aderida ao material de preenchimento. É possível que este valor tenha diminuído após os decantadores, não analisado por não ser o foco desta pesquisa.

Observa-se também que não houve considerável remoção dos sólidos suspensos do esgoto. 


\subsection{Filtros percoladores em escala piloto - ETAPA 02}

Os dois filtros percoladores em escala piloto receberam o efluente da lagoa facultativa, sob as condições operacionais apresentadas nas Figuras $5.13 \mathrm{e}$ 5.14 .
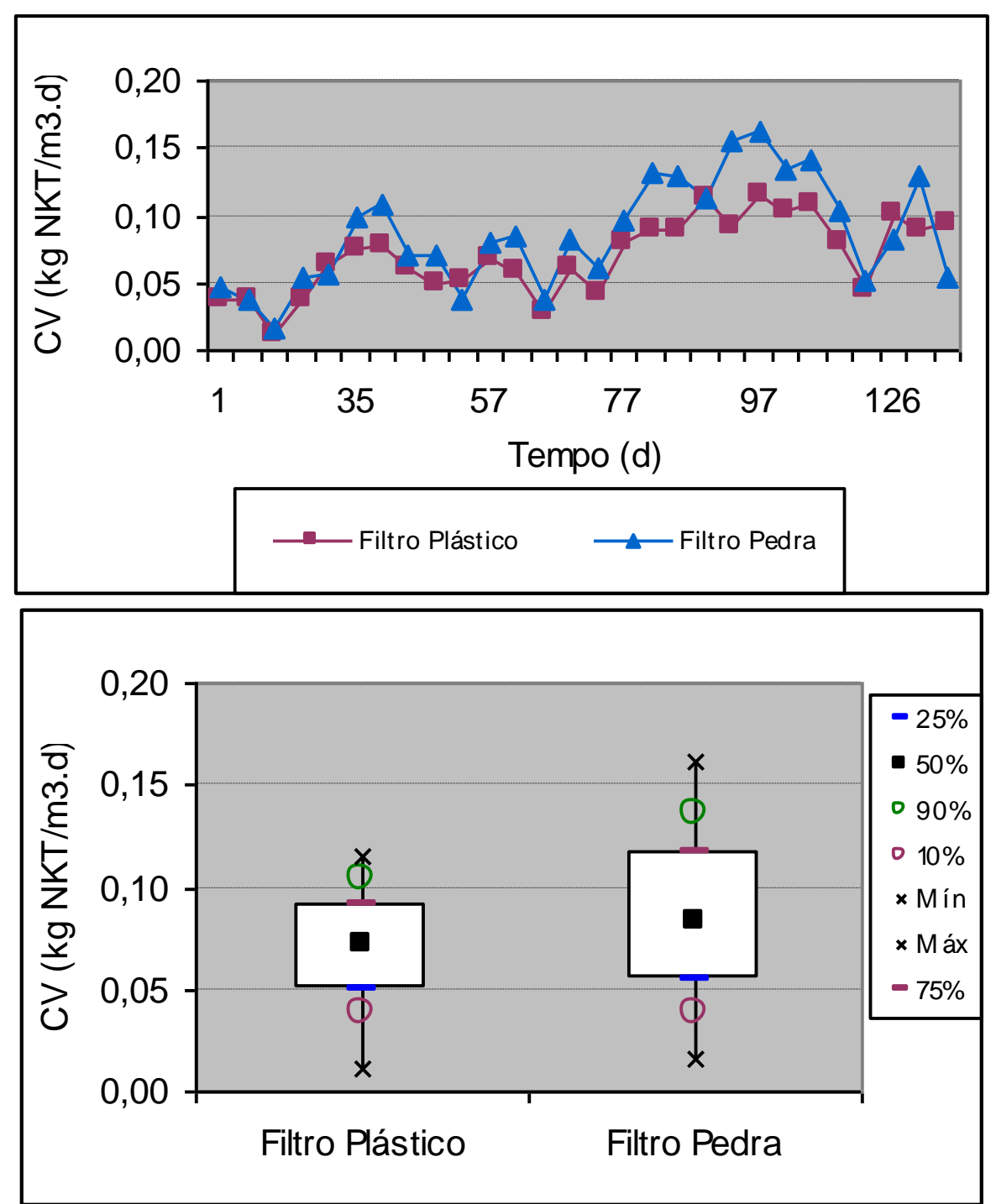

Figura 5.13: Carga volumétrica de NKT - ETAPA 02 

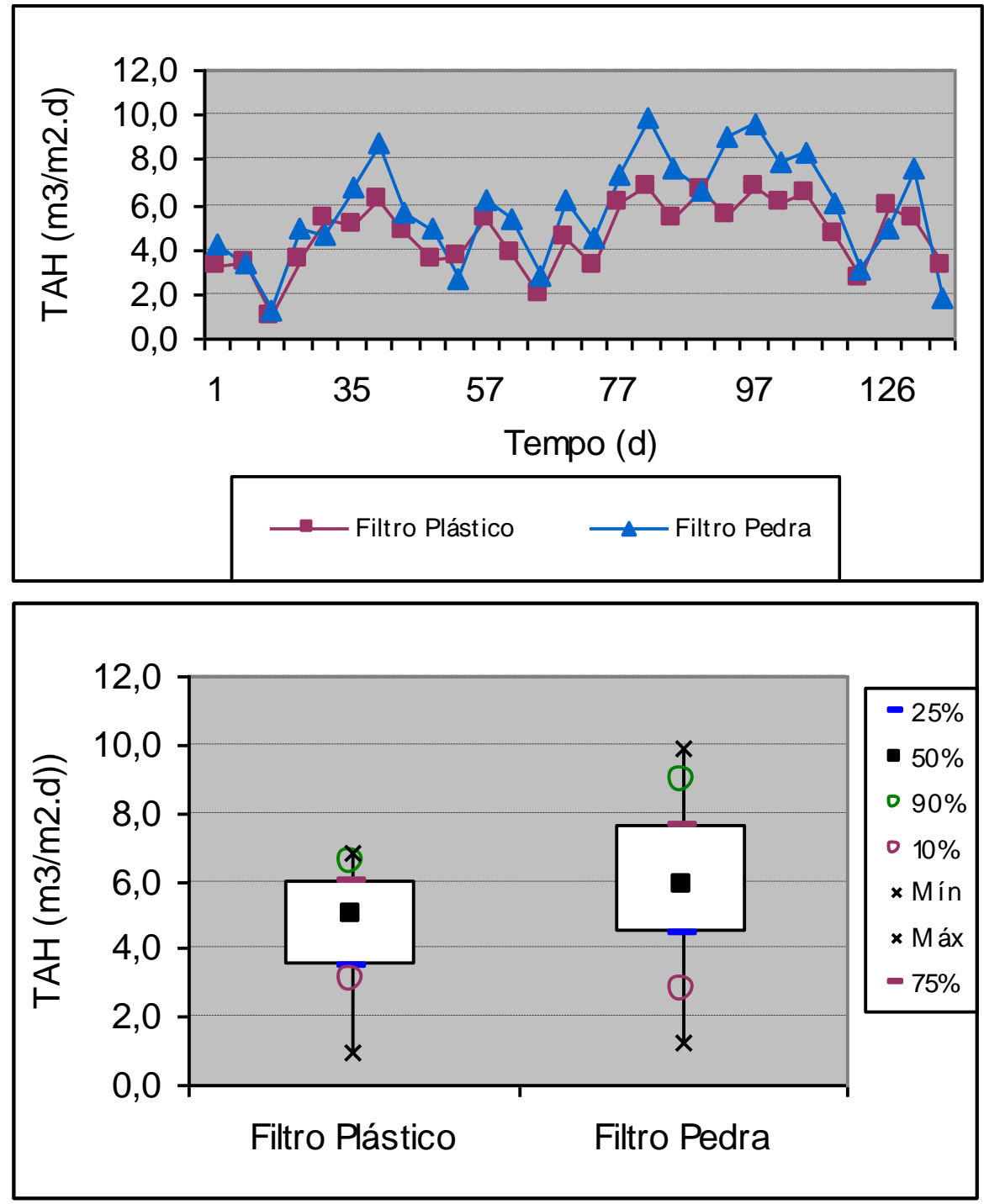

Figura 5.14: Taxa de aplicação hidráulica superficial nos filtros - ETAPA 02

Observa-se novamente que não houve diferenças significativas entre as taxas aplicadas no filtro com leito de pedra e plástico. Cerca de $50 \%$ dos valores ficaram com taxas de $5 \mathrm{~m}^{3} / \mathrm{m}^{2}$.d no Filtro de Plástico e $5,9 \mathrm{~m}^{3} / \mathrm{m}^{2}$.d no Filtro de Pedra. A carga volumétrica de nitrogênio total Kjedahl teve como mediana os valores de 0,07 $\mathrm{KgNKT} / \mathrm{m}^{3}$.d para o Filtro de Plástico e 0,08 $\mathrm{KgNKT/} \mathrm{m}{ }^{3} . \mathrm{d}$ para o Filtro de Pedra. 


\subsubsection{Eficiência de molhamento dos meios suporte - ETAPA 02}

Os cálculos de eficiência de molhamento da ETAPA 02 são apresentados a seguir:

- Eficiência de molham ento na Etapa 2 - Filtro Plástico

$\operatorname{Ef}(\%)=\mathrm{TAH} /\left[\mathrm{TAH}+\left(\Gamma \times \mathrm{A}_{s}\right)\right]=5,0 /[5,0+(0,113 \times 100)]=31 \%$

- Eficiência de molhamento na Etapa 2 - Filtro Pedra

$\mathrm{Ef}(\%)=\mathrm{TAH} /\left[\mathrm{TAH}+\left(\check{\Gamma} \times A_{s}\right)\right]=5,9 /[5,9+(0,113 \times 70)]=43 \%$

Os cálculos apresentados demonstram que a taxa de aplicação hidráulica superficial utilizada na Etapa 02 não foi suficiente para promover o molhamento eficiente de toda a superfície de meio suporte, permitido o molhamento de apenas 31 e $43 \%$ da superfície total dos filtros de plástico e pedra, respectivamente.

\subsubsection{Parâmetros de controle - ETAPA 02}

As Figuras 5.15, 5.16, 5.17 e 5.18 apresentam uma estatística dos parâmetros de controle, como pH, temperatura, alcalinidade e concentração de oxigênio dissolvido dos efluentes.

Durante a Etapa 02, pode ser observado que os efluentes dos filtros apresentaram $50 \%$ dos valores de $\mathrm{pH}$ na faixa de 7,7 enquanto que o afluente apresentou valores de 7,4, o que se pode observar uma não redução de valores de $\mathrm{pH}$ quando comparados o afluente e o efluente. 


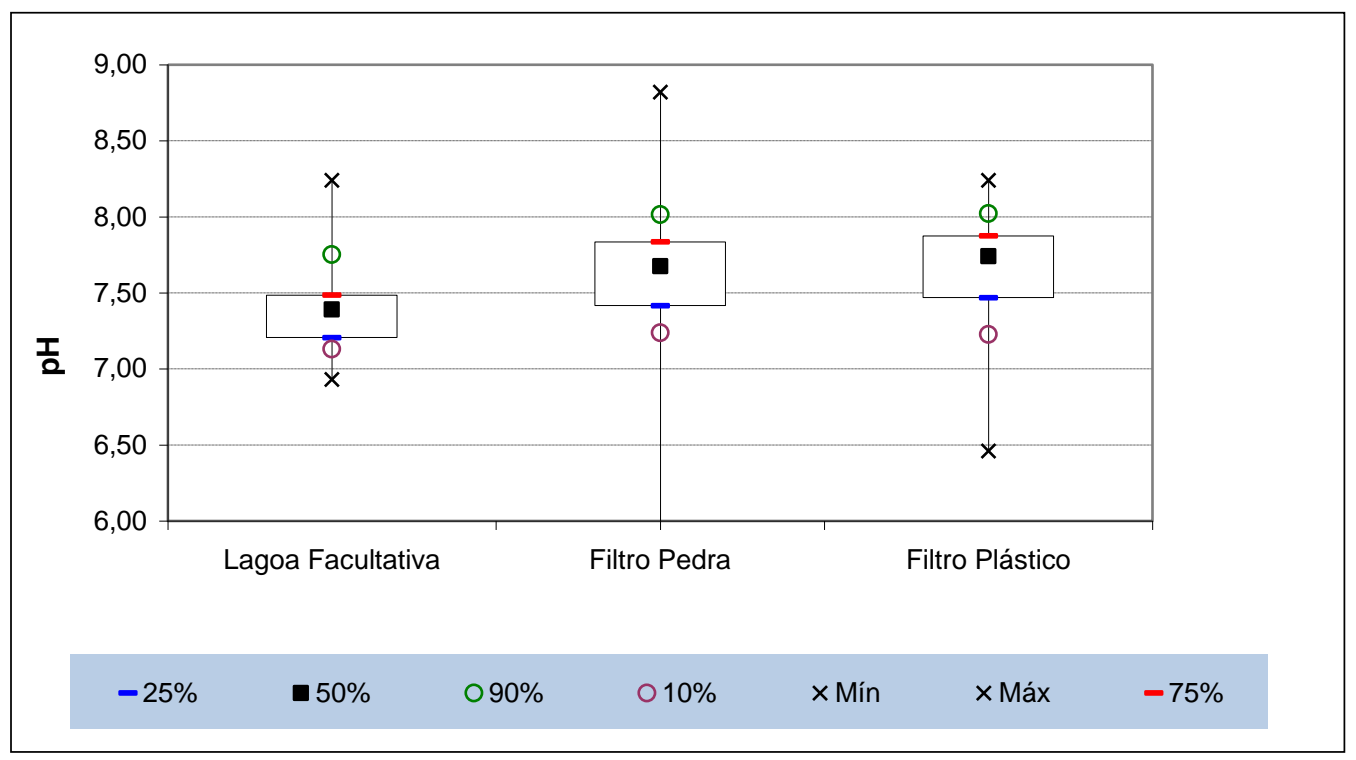

Figura 5.15: $\mathrm{pH}$ afluente e efluente dos filtros percoladores em escala piloto ETAPA 02

Os valores de temperatura mantiveram na faixa de $22^{\circ} \mathrm{C} \mathrm{em}$ ambos os filtros e na Lagoa Facultativa, a temperatura do ar manteve-se na faixa de $23^{\circ} \mathrm{C}$.

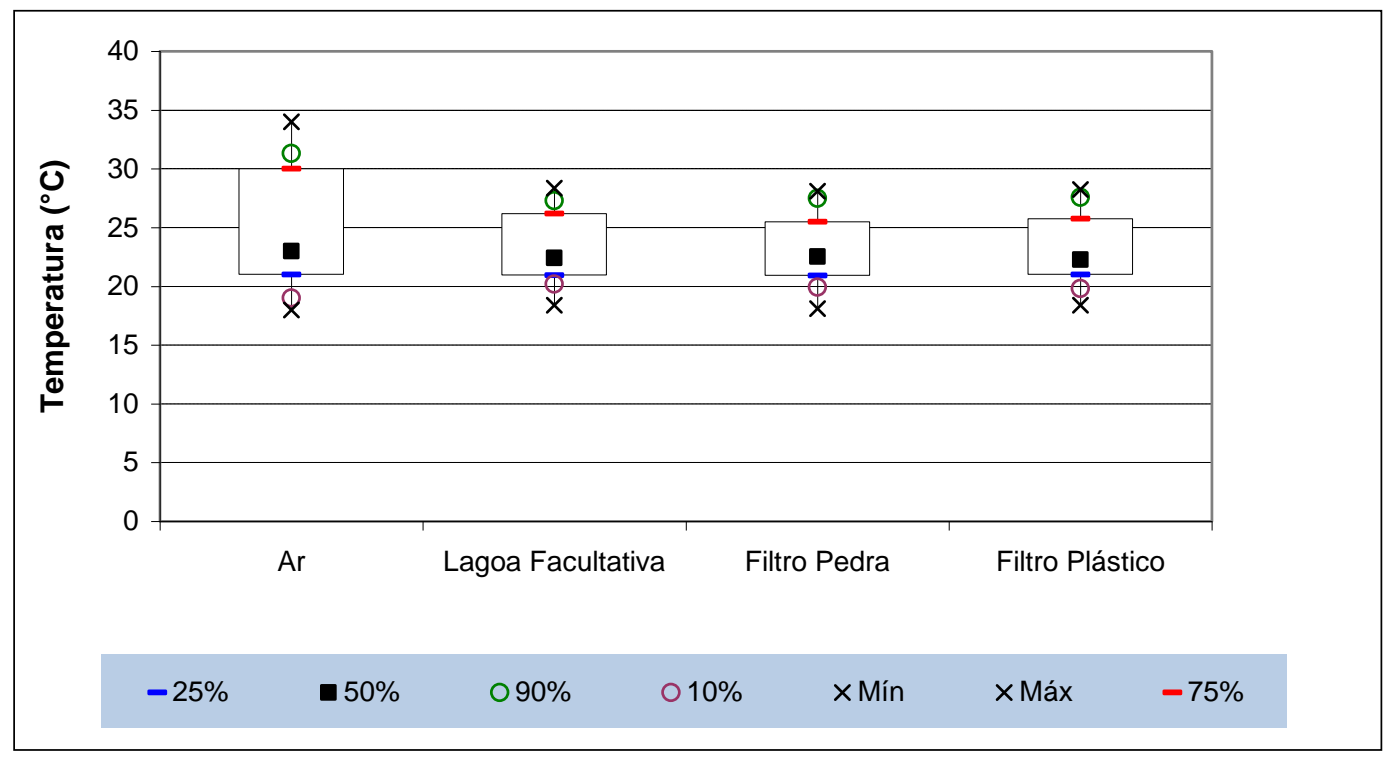

Figura 5.16: Temperatura afluente e efluente dos filtros percoladores em escala piloto - ETAPA 02

Durante a Etapa 2, 50\% dos valores de alcalinidade mantiveram com $220 \mathrm{mg} / \mathrm{L}$ no filtro de pedra e $240 \mathrm{mg} / \mathrm{L}$ no filtro de plástico e um afluente com $420 \mathrm{mg} / \mathrm{L}$. 
Com uma taxa de maior consumo de alcalinidade do filtro preenchido com pedra é indicativo de maior grau de nitrificação.

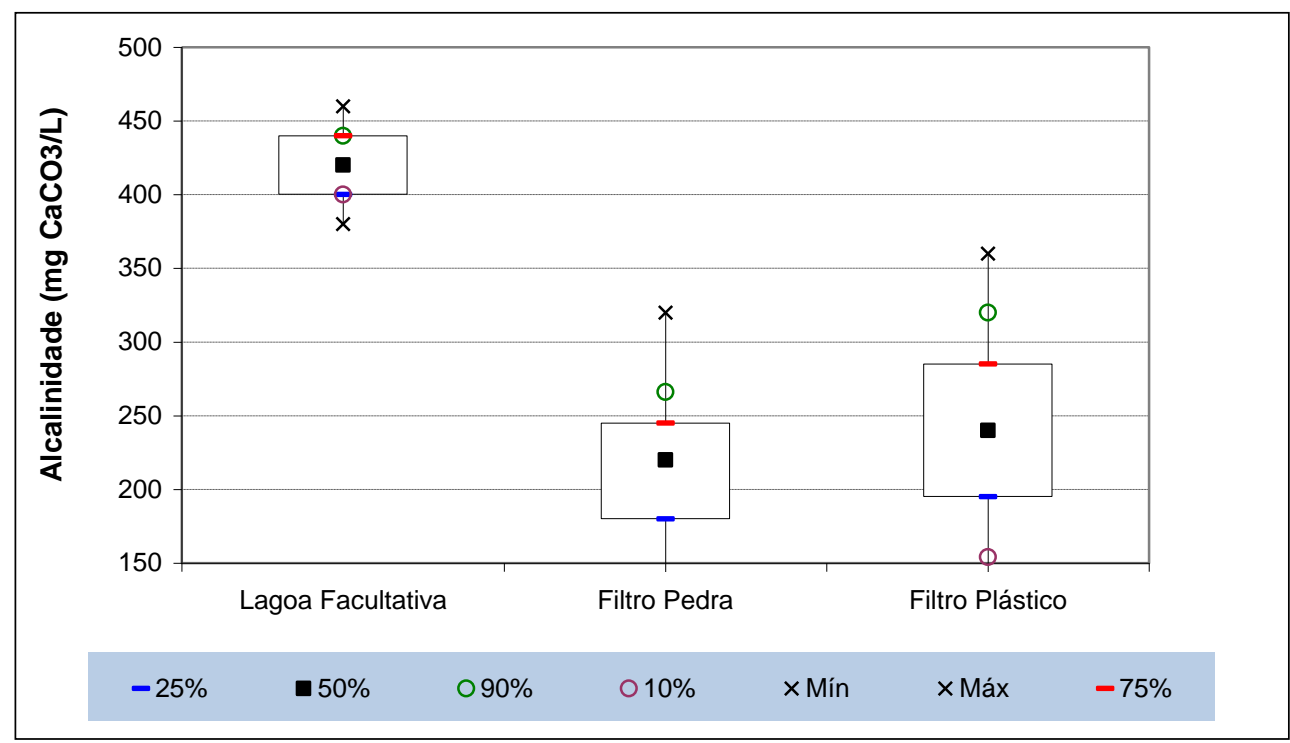

Figura 5.17: Alcalinidade afluente e efluente dos filtros percoladores em escala piloto - ETAPA 02

$\mathrm{Na}$ Figura 5.18, pode se observar que cerca de $50 \%$ dos valores de OD mantiveram uma concentração de $6,3 \mathrm{mg} / \mathrm{L}$ no Filtro de Pedra e $6,0 \mathrm{mg} / \mathrm{L}$ no Filtro de Plástico, continuando o valor bem acima do valor mínimo necessário para garantir que a nitrificação não seja limitada pela disponibilidade de oxigênio. O afluente ao filtro biológico manteve $50 \%$ dos valores em $0,0 \mathrm{mg} / \mathrm{L}$. 


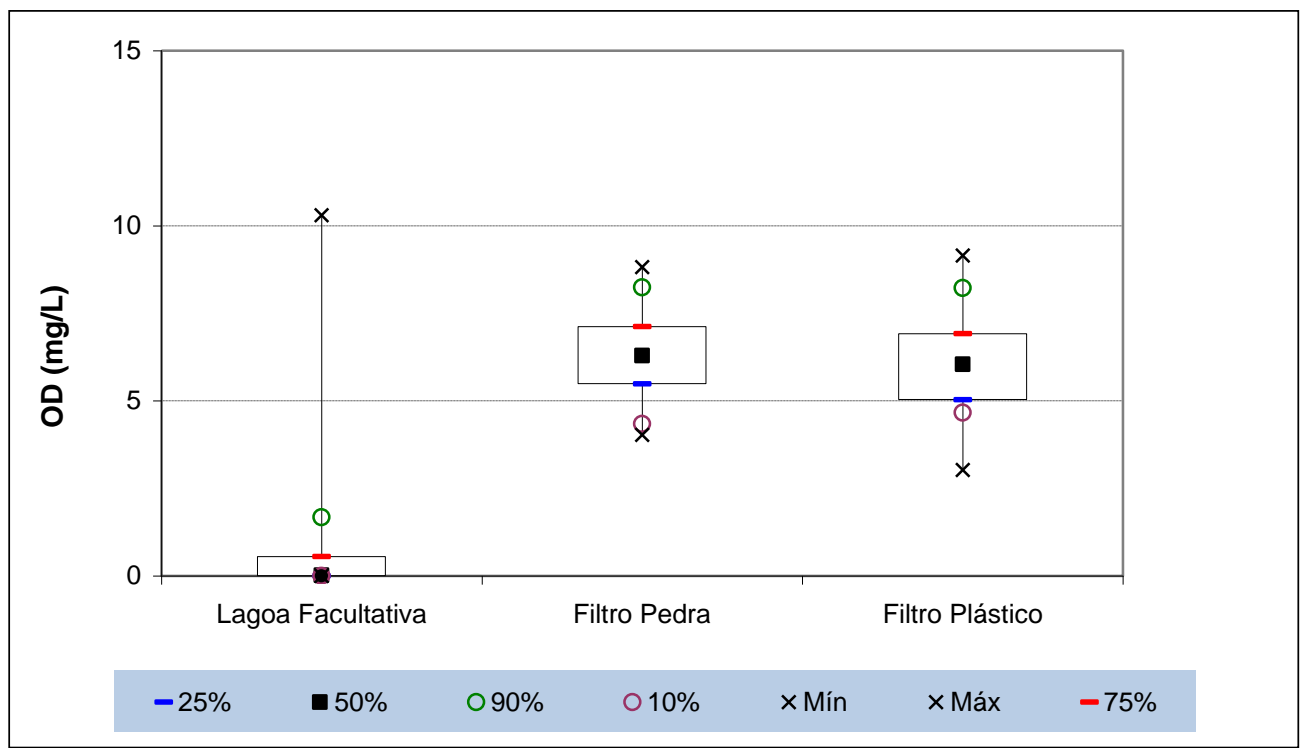

Figura 5.18: Concentração de oxigênio dissolvido afluente e efluente dos filtros percoladores em escala piloto - ETAPA 02

\subsubsection{Formas nitrogenadas - ETAPA 02}

As Figuras 5.19, 5.20, 5.21 e 5.22 apresentam as séries históricas de todas as formas nitrogenadas.

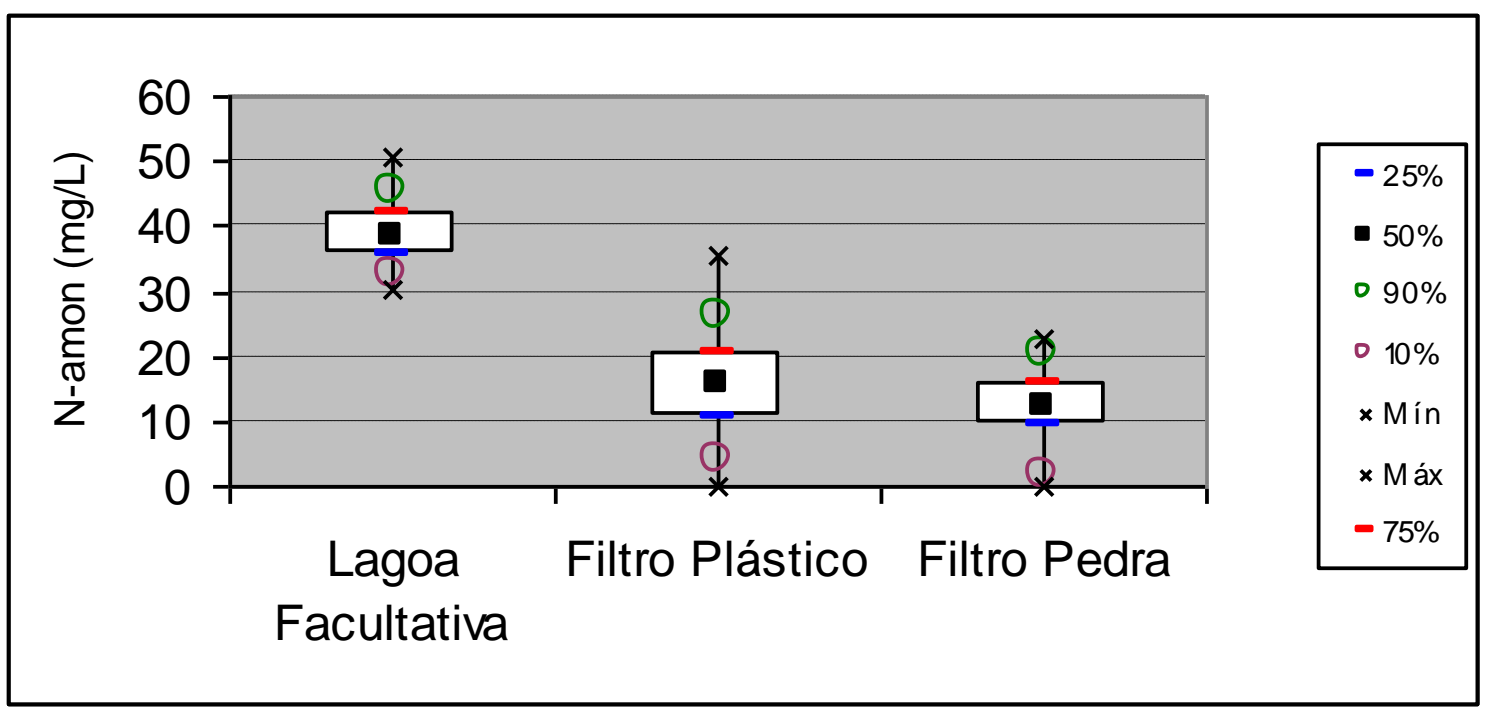




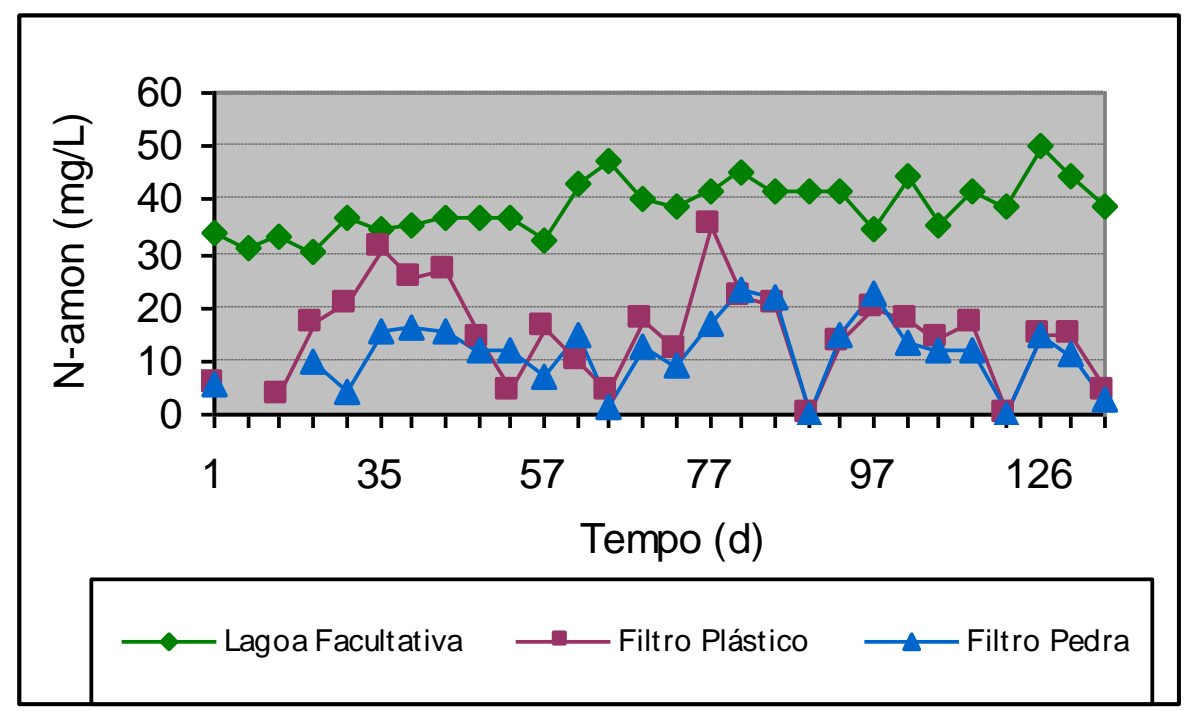

Figura 5.19: Diagrama box-whisker e série histórica de nitrogênio amoniacal ETAPA 02

Nesta segunda etapa, a remoção do nitrogênio amoniacal continua sendo mais significativa no filtro preenchido com brita, uma vez ter apresentado em seu efluente final concentração medianos de $15,7 \mathrm{mg} / \mathrm{l}$, enquanto que no filtro com anéis de plástico, a concentração esteve em aproximadamente 12,7 mg/l, acreditando ainda ser um reflexo da Etapa 01 e da superfície rugosa da brita. Apesar do valor mediano de concentração de $\mathrm{N}_{-} \mathrm{NH}_{3}$ ter sido menor no filtro de plástico, a média se mantem dentro de uma mesma faixa, o que nos leva a analisar as duas taxas de remoções desta etapa como sendo iguais; o que é comprovado analisando a figura 5.20 . 


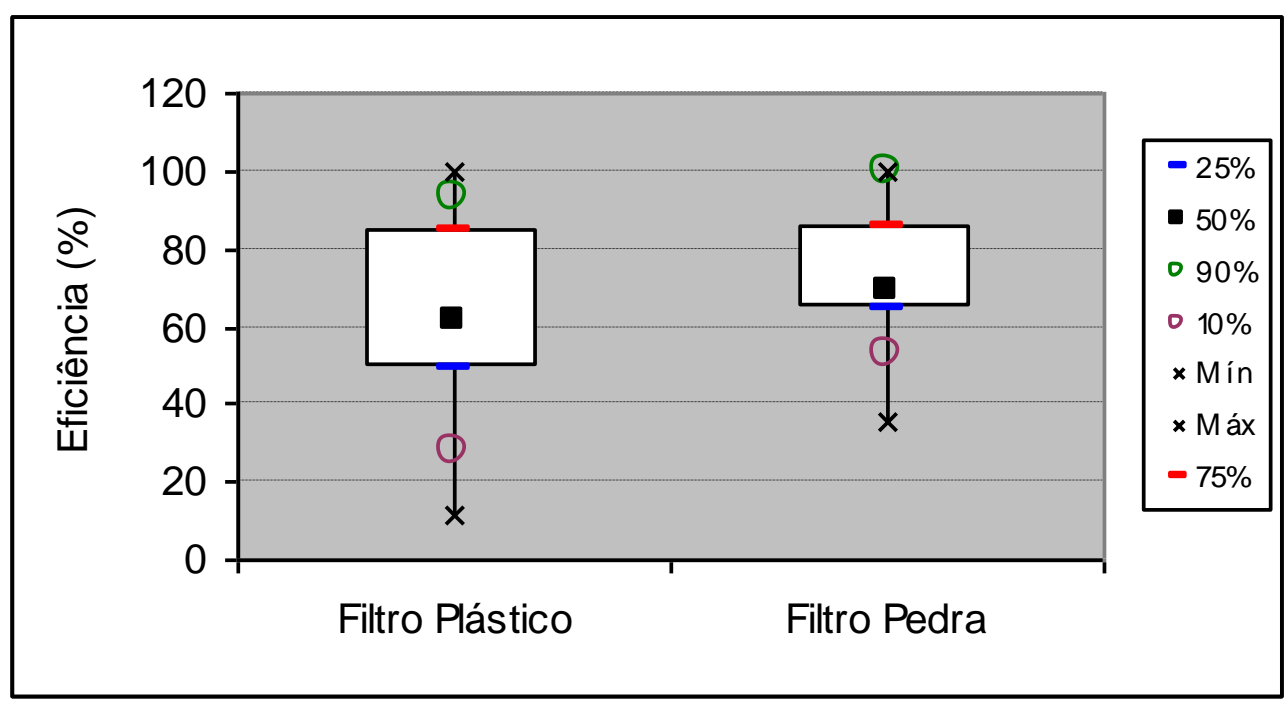

Figura 5.20: Características estatísticas da concentração de nitrogênio amoniacal dos filtros percoladores em escala piloto - ETAPA 02

Os valores medianos de nitrito aingiram $8 \mathrm{mg} / \mathrm{L}$ no filtro de plástico e $5,8 \mathrm{mg} / \mathrm{L}$ no filtro de pedra, já os valores de nitrato chegaram a $9,5 \mathrm{mg} / \mathrm{L}$ no filtro de plástico e 12,8 mg/L no filtro de pedra.

Nesta etapa podemos relatar que houve acúmulo de nitrito em ambos os filtros, assim como nos primeiros meses de operação da primeira etapa, indicando inibição da nitratação. Os valores de concentração de nitratos podem estar incorretos, em função de problemas analíticos devido à saturação da coluna de cádmio. Esta coluna foi substituída e as concentrações de nitrato no efluente final se elevaram na etapa seguinte. Embora continue ocorrendo acúmulo de nitrito, o balanço da nitrificação tem demonstrado maior convergência, de forma a garantir que o efeito de volatilização é pequeno.

Os gráficos de Box \& whiskers com os percentis dos valores de nitrito e nitrato estão demostrados nas Figuras 5.21 e 5.22. 

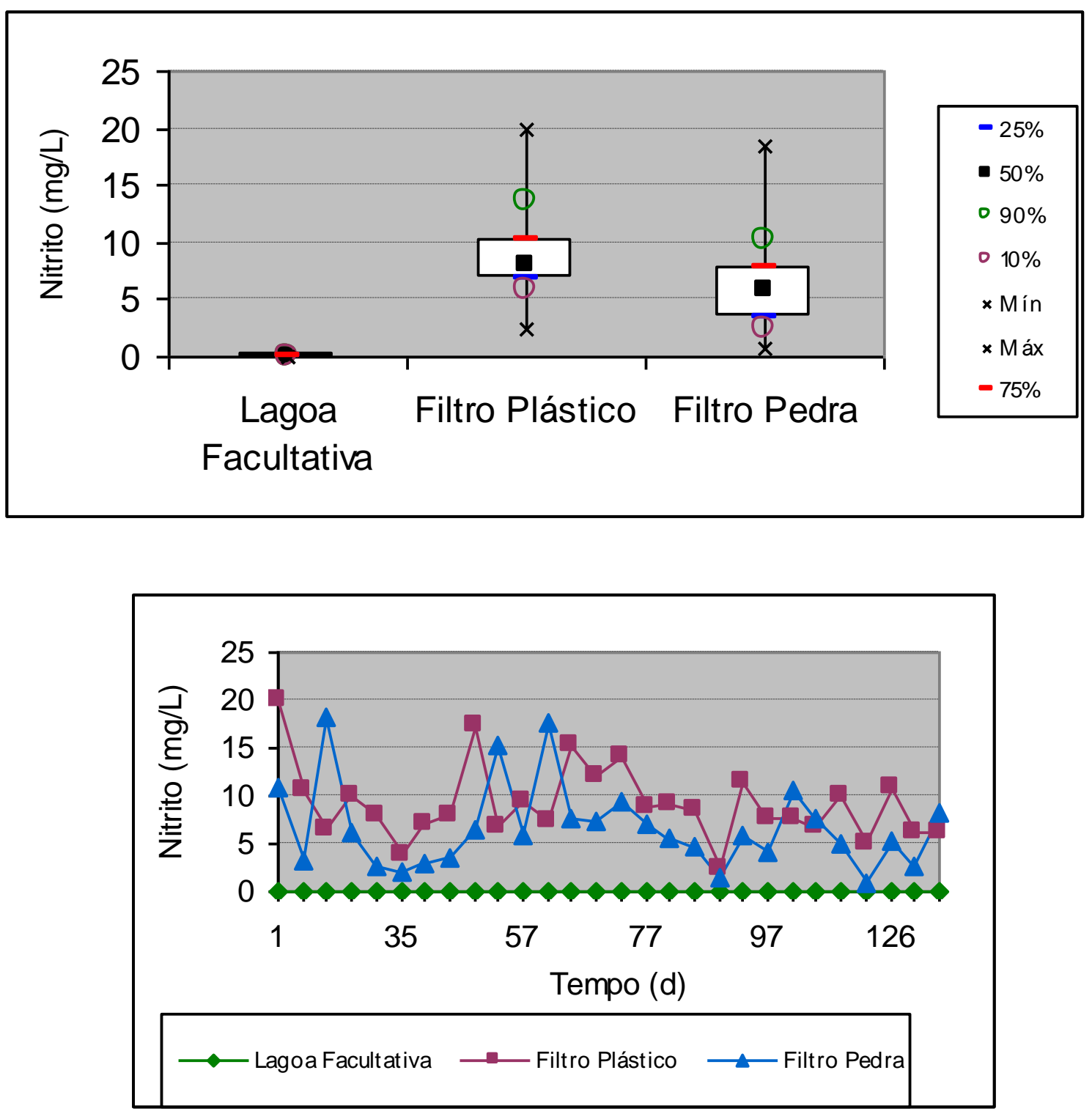

Figura 5.21: Diagrama box-whisker e série histórica de nitrito - ETAPA 02

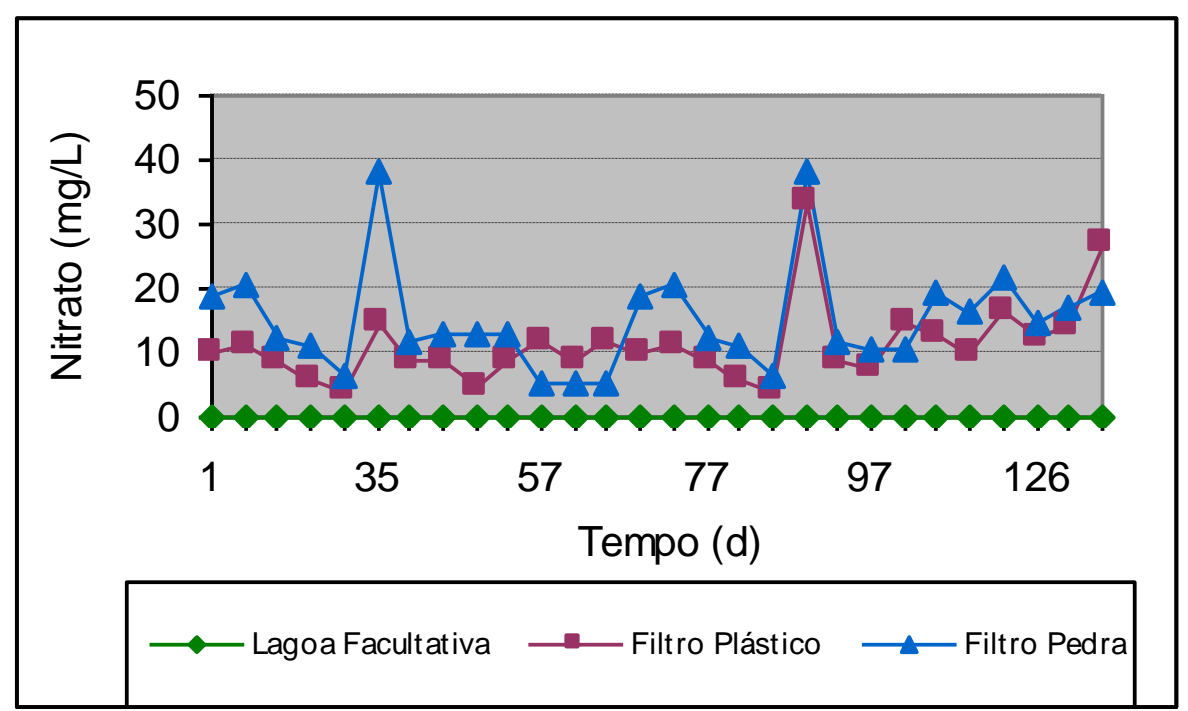




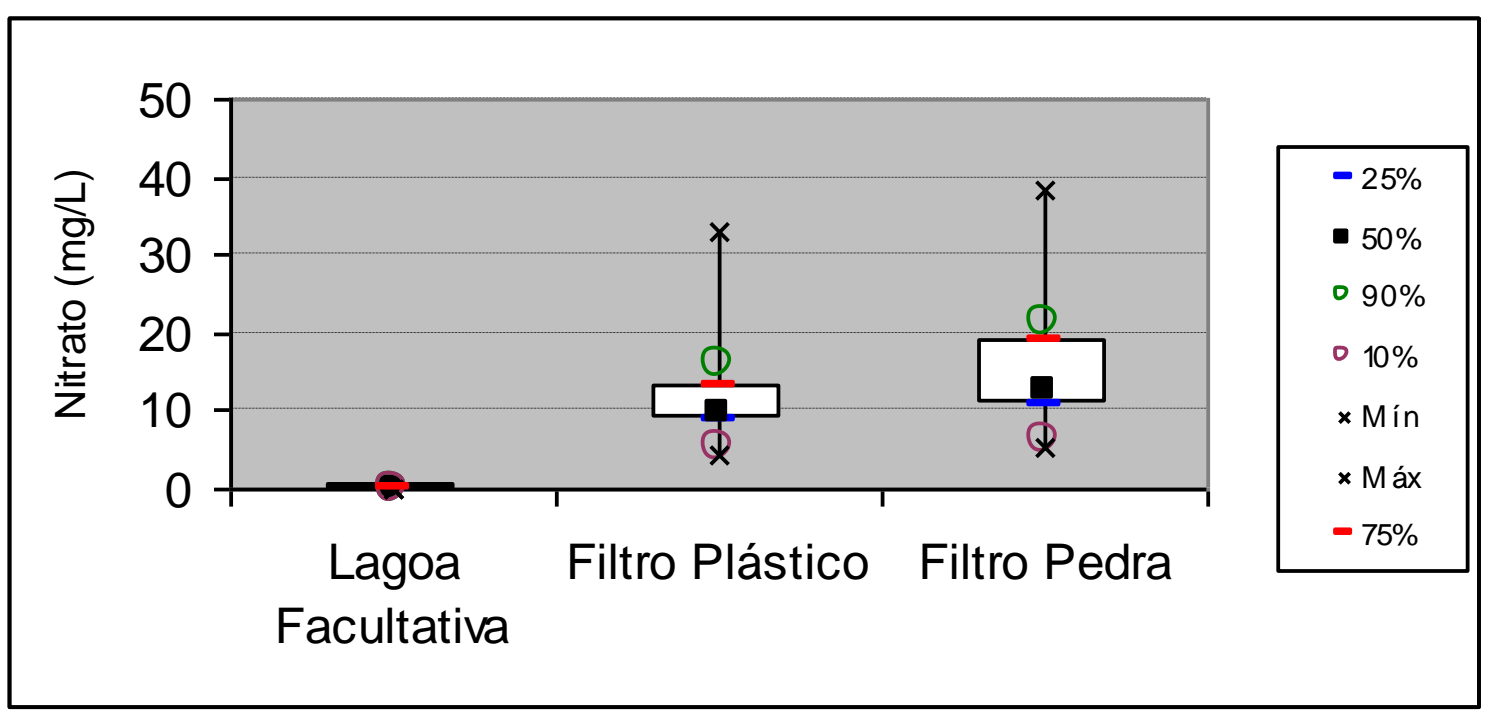

Figura 5.22: Diagrama box-whisker e série histórica de nitrato - ETAPA 02

\subsubsection{DQO, DBO e SST - ETAPA 02}

As Figuras 5.23 e 5.24 ilustram respectivamente as séries históricas das concentrações de DQO, DBO e SST da Lagoa Facultativa e do efluente dos Filtros de Plástico e Pedra, e a tabela 6.2 demonstra a estatística descritiva dos referidos parâmetros.

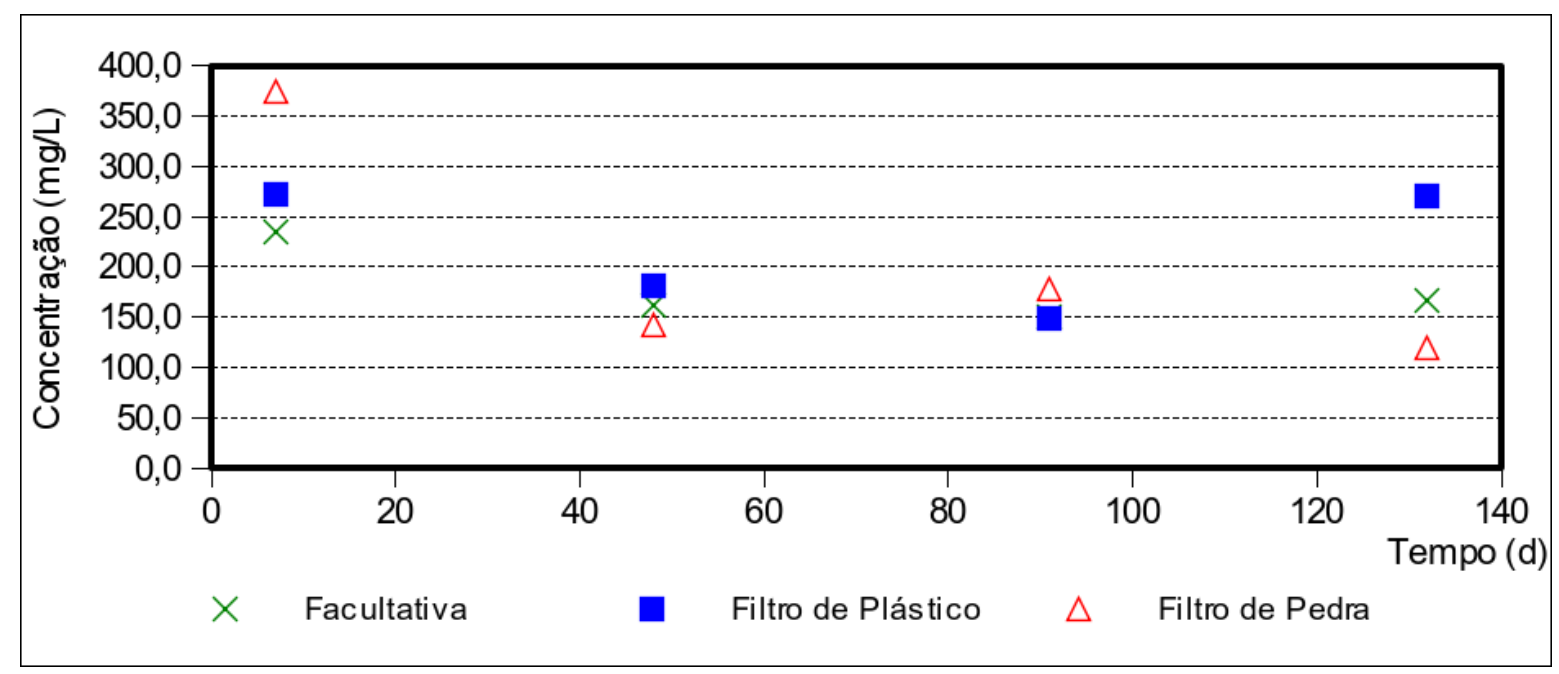




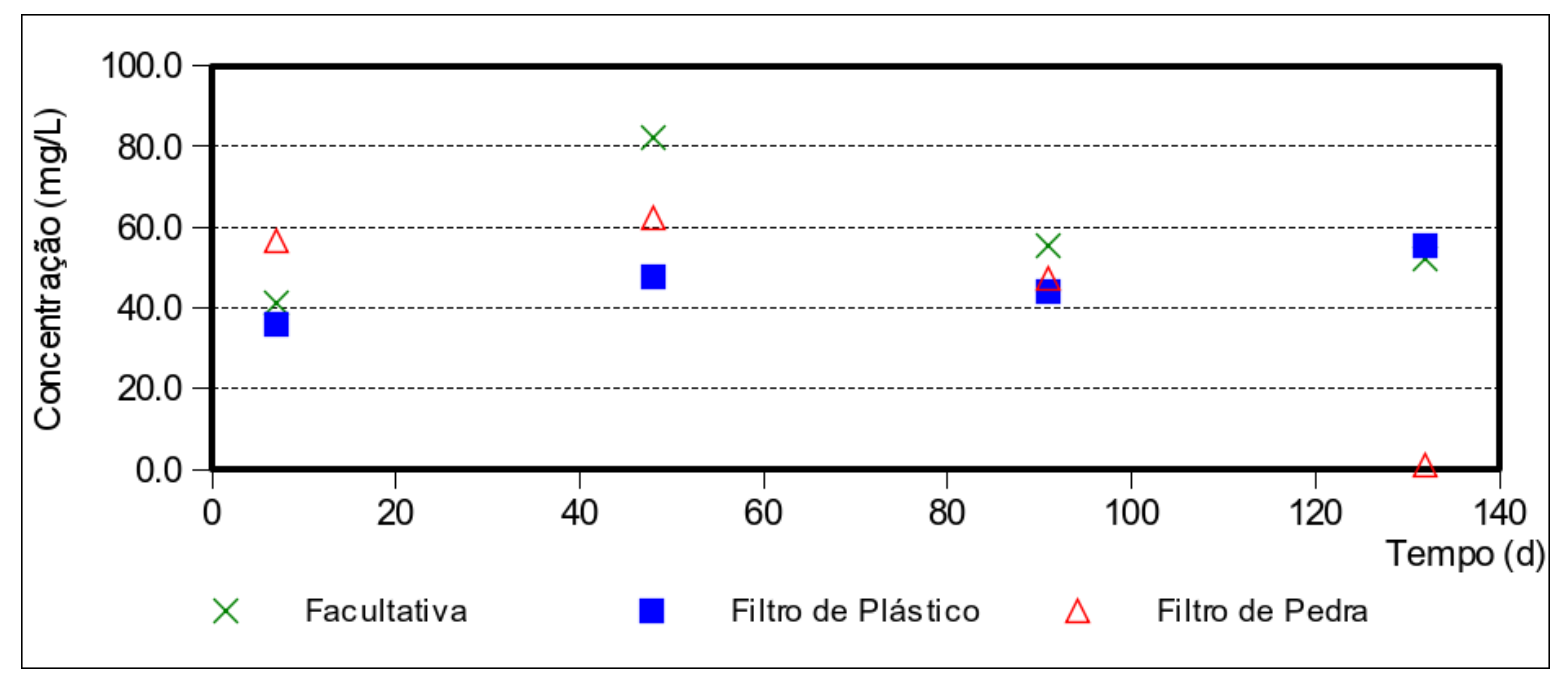

Figura 5.23: Concentrações de DQO e DBO dos efluentes - ETAPA 02

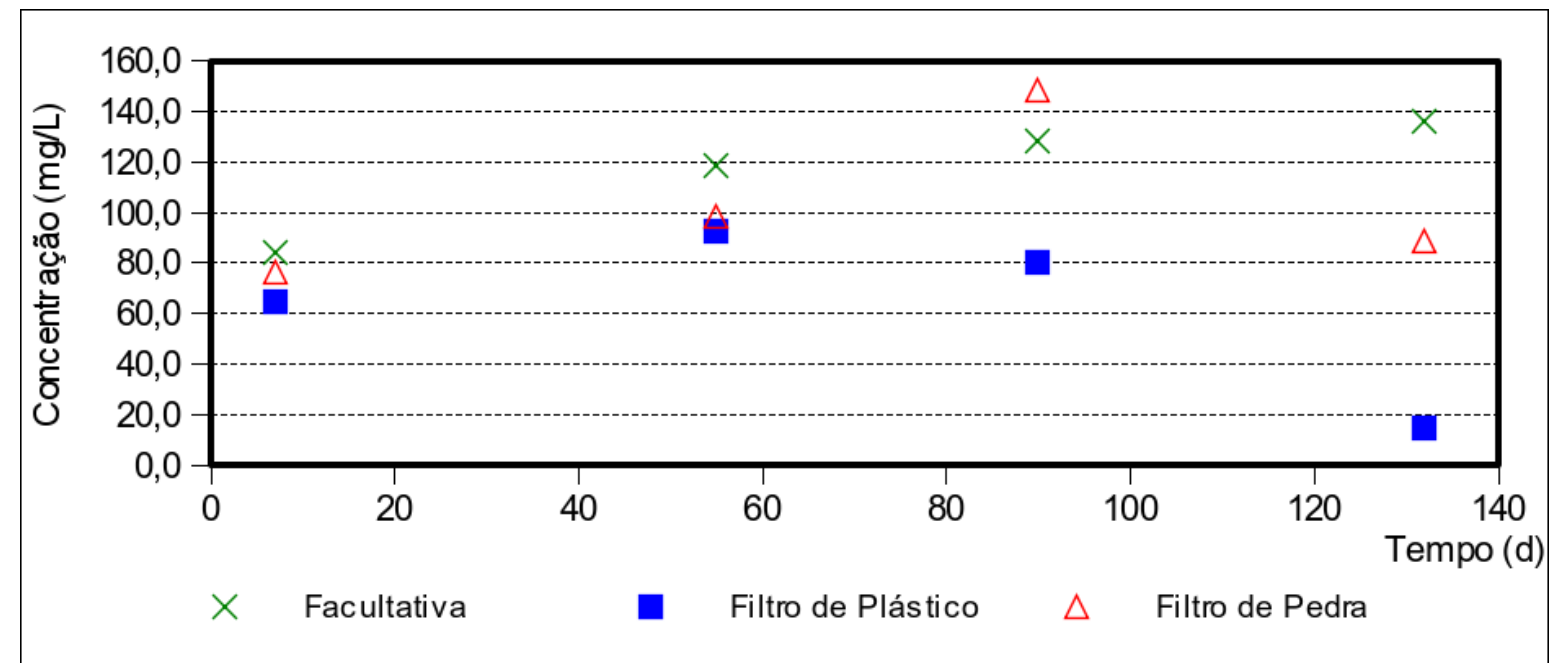

Figura 5.24: Gráfico de dispersão da concentração de sólidos em suspensão totais - ETAPA 02

Tabela 5.2: Estatística descritiva das medianas de DQO, DBO e SST - ETAPA 02

\begin{tabular}{|l|l|c|c|c|}
\hline & & $\mathrm{DQO}(\mathrm{mg} / \mathrm{L})$ & $\mathrm{DBO}(\mathrm{mg} / \mathrm{L})$ & $\mathrm{SST}(\mathrm{mg} / \mathrm{L})$ \\
\hline \multirow{3}{*}{ Etapa 02 } & Lagoa Facultativa & 220 & 50 & 130 \\
\cline { 2 - 5 } & Filtro Plástico & 140 & 45 & 70 \\
\cline { 2 - 5 } & Filtro Pedra & 125 & 50 & 90 \\
\hline
\end{tabular}


Observa-se que na Etapa 02 continua não ocorrendo remoção adicional de DBO nos filtros. Nesta etapa houve remoção de DQO na faixa de $64 \%$ no filtro de plástico e de $54 \%$ no filtro de pedra. Já sólidos suspensos, houve também uma remoção de $54 \%$ no filtro de plástico e de $70 \%$ no filtro de pedra.

\subsubsection{Filtros percoladores em escala piloto - ETAPA 03}

Os dois filtros percoladores em escala piloto receberam o efluente da lagoa facultativa, sob as condições operacionais apresentadas nas Figuras $5.25 \mathrm{e}$ 5.26 .
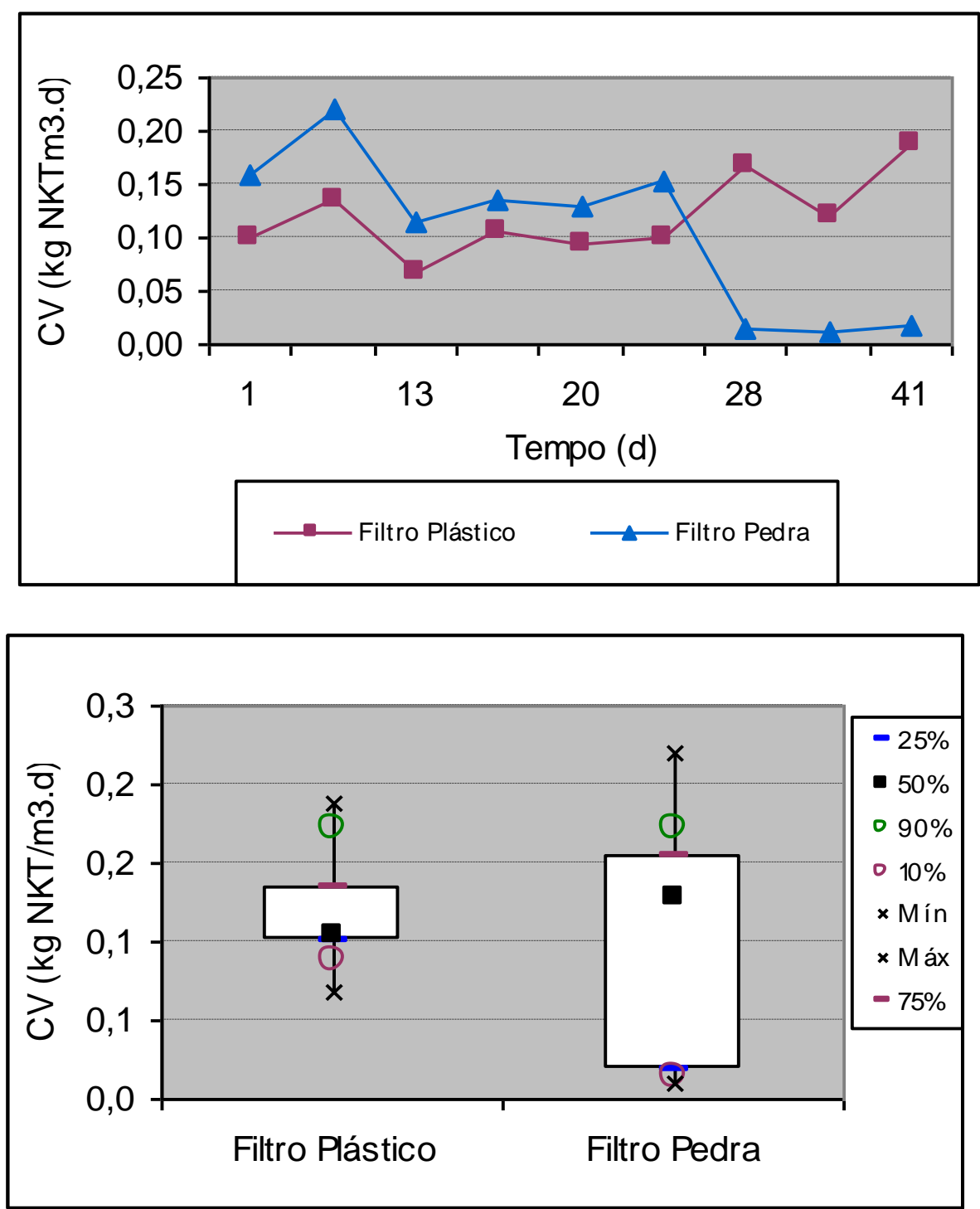

Figura 5.25: Carga volumétrica de NKT - ETAPA 03 

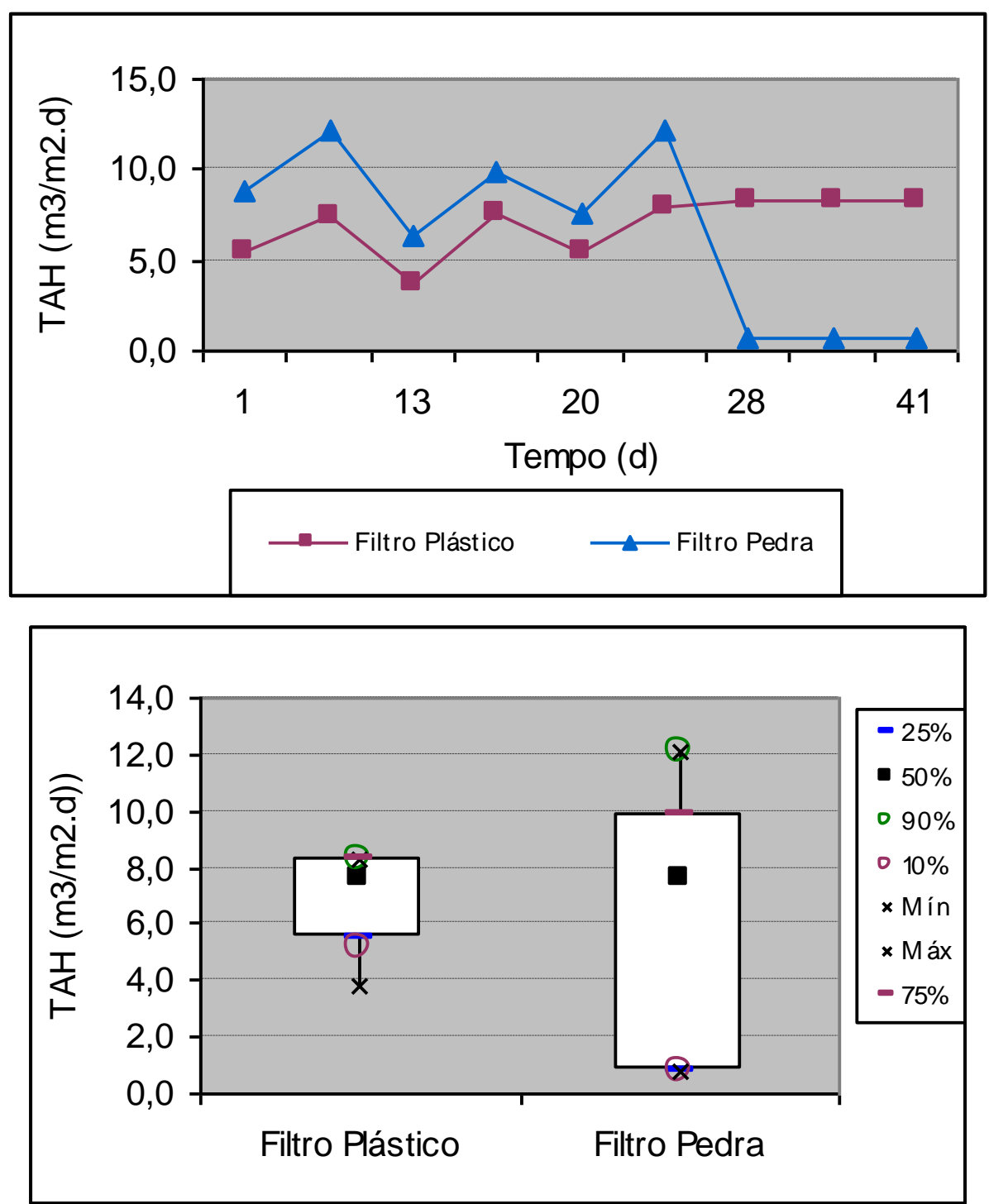

Figura 5.26: Taxa de aplicação hidráulica superficial nos filtros - ETAPA 03

Observa-se novamente que não houve diferenças significativas entre as taxas aplicadas no filtro com leito de pedra e plástico. Cerca de $50 \%$ dos valores ficaram com taxas de 7,6 $\mathrm{m}^{3} / \mathrm{m}^{2}$.d em ambos os filtros. A carga volumétrica de nitrogênio total Kjedahl teve como mediana os valores de 0,10 $\mathrm{KgNKT/} \mathrm{m}^{3} . \mathrm{d}$ para o Filtro de Plástico e $0,13 \mathrm{KgNKT/} \mathrm{m}^{3}$.d para o Filtro de Pedra.

\subsubsection{Eficiência de molhamento dos meios suporte - ETAPA 03}


Os cálculos de eficiência de molhamento da ETAPA 03 são apresentados a seguir:

- Eficiência de molham ento na Etapa 3 - Filtro Plástico

$\mathrm{Ef}(\%)=\mathrm{TAH} /[\mathrm{TAH}+(\ulcorner\times \mathrm{As})]=7,6 /[7,6+(0,113 \times 100)]=40 \%$

- Eficiência de molhamento na Etapa 3 - Filtro Pedra

$\mathrm{Ef}(\%)=\mathrm{TAH} /\left[\mathrm{TAH}+\left(\check{\Gamma} \times \mathrm{A}_{\mathrm{s}}\right)\right]=7,6 /[7,6+(0,113 \times 70)]=49 \%$

Os cálculos apresentados demonstram que a taxa de aplicação hidráulica superficial utilizada na Etapa 03 não foram suficientes para promover 0 molhamento eficiente de toda a superfície de meio suporte, permitido o molhamento de apenas 40 e $49 \%$ da superfície total dos filtros de plástico e pedra, respectivamente.

\subsubsection{Parâmetros de controle - ETAPA 03}

As Figuras 5.27, 5.28, 5.29 e 5.30 apresentam uma estatística dos parâmetros de controle, como $\mathrm{pH}$, temperatura, alcalinidade e concentração de oxigênio dissolvido dos efluentes.

Durante a Etapa 03, observou-se que a mediana dos resultados de $\mathrm{pH}$ monitorados nos efluentes dos filtros de pedra e de plástico estiveram em 7,6, enquanto que o afluente apresentou valores de 7,5 . Valores de $\mathrm{pH}$ próximos à neutralidade são ruins para o processo de nitrificação, pois inibem a ação das nitrossomas e nitrobacters pelo acúmulo de amônia ionizada. 


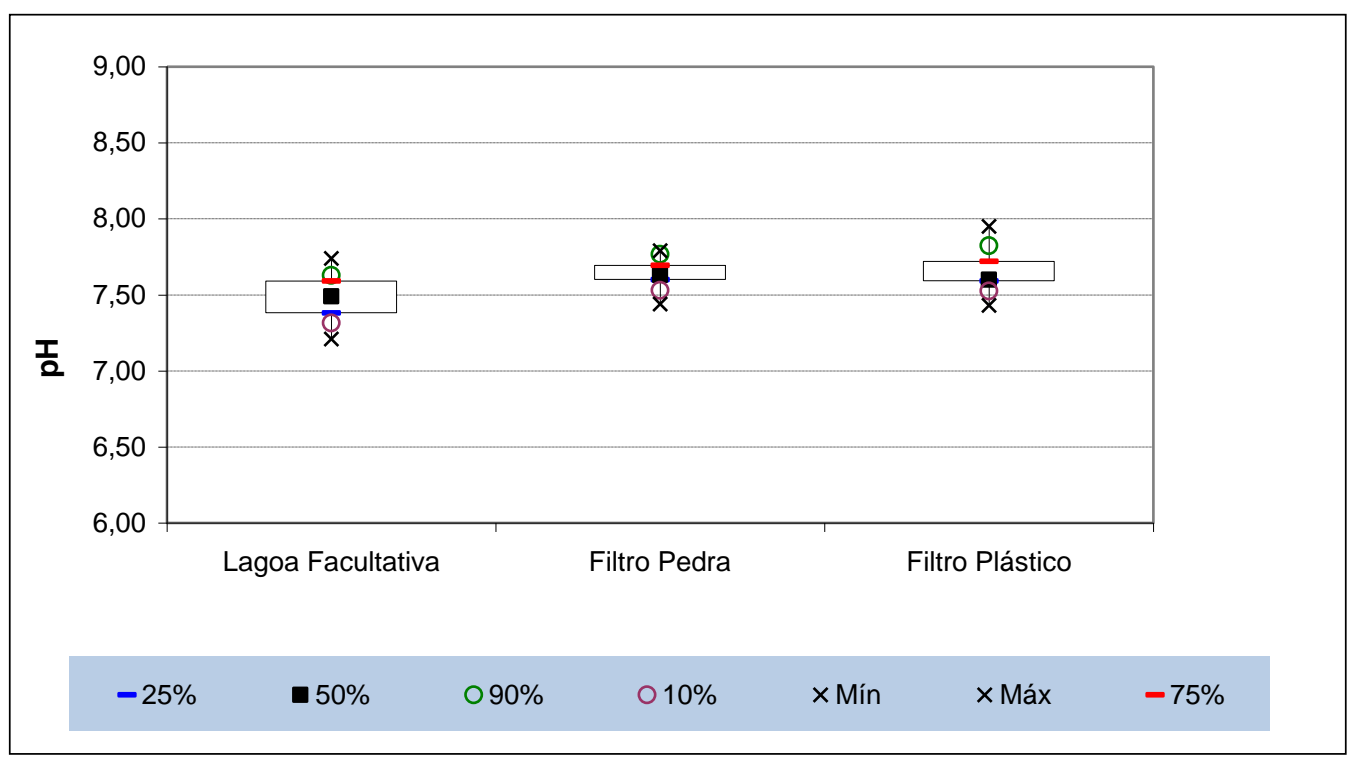

Figura 5.27: $\mathrm{pH}$ afluente e efluente dos filtros percoladores em escala piloto - ETAPA 03

Os valores de temperatura mantiveram na faixa de $24^{\circ} \mathrm{C}$ em ambos os filtros e na Lagoa Facultativa, a temperatura do ar manteve-se na faixa de $26^{\circ} \mathrm{C}$.

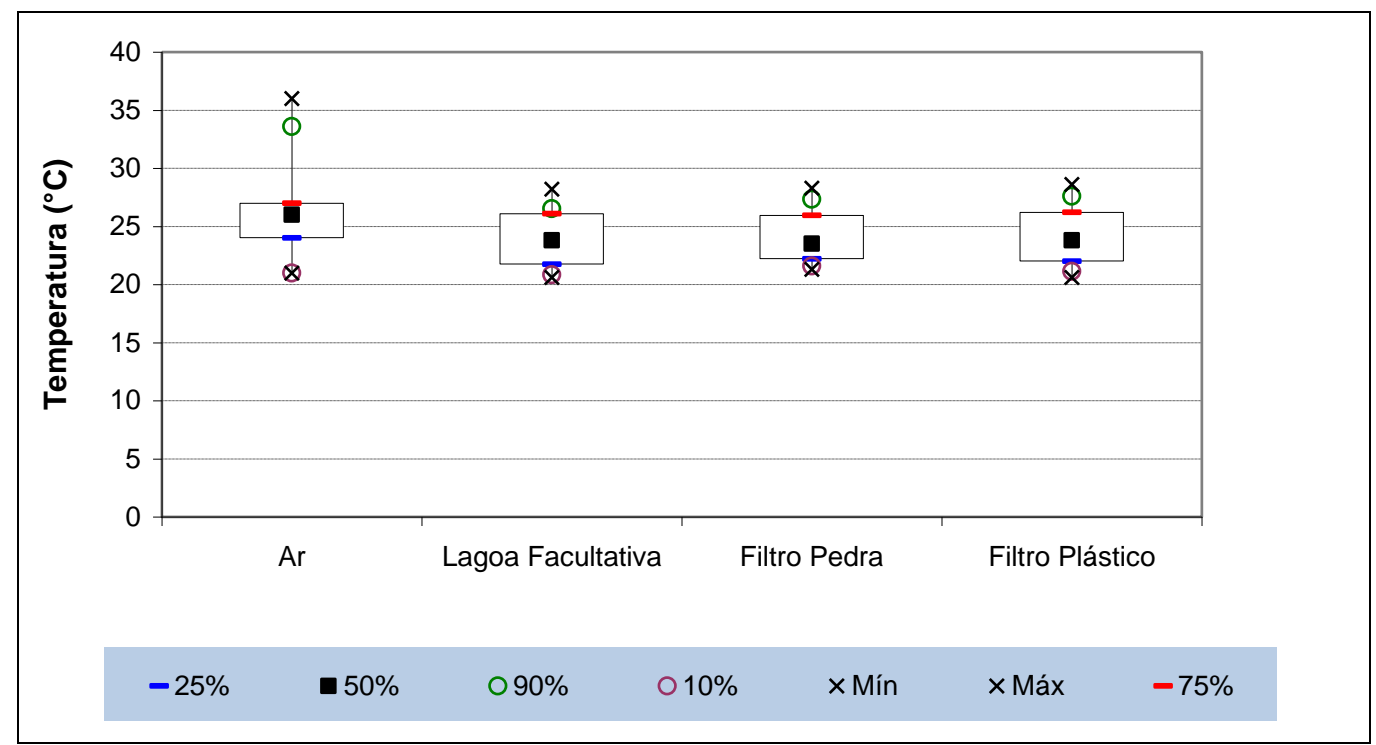

Figura 5.28: Temperatura afluente e efluente dos filtros percoladores em escala piloto - ETAPA 03

Quanto a alcalinidade, metade dos valores obtidos no filtro de pedra estiveram na ordem de $280 \mathrm{mg} / \mathrm{L}$, enquanto que no filtro de plástico, a alcalinidade esteve em $260 \mathrm{mg} / \mathrm{L}$. Tais resultados foram inferiores ao verificado no afluente, o qual se apresentou com 420 mg/L. Como a queda de alcalinidade está associada à nitrificação, pode-se dizer que houve maior grau de nitrificação no filtro 
preenchido com plástico, conforme será verificado na análise das séries nitrogenadas no subitem 5.1.3.3 - Formas Nitrogenadas - ETAPA 3.

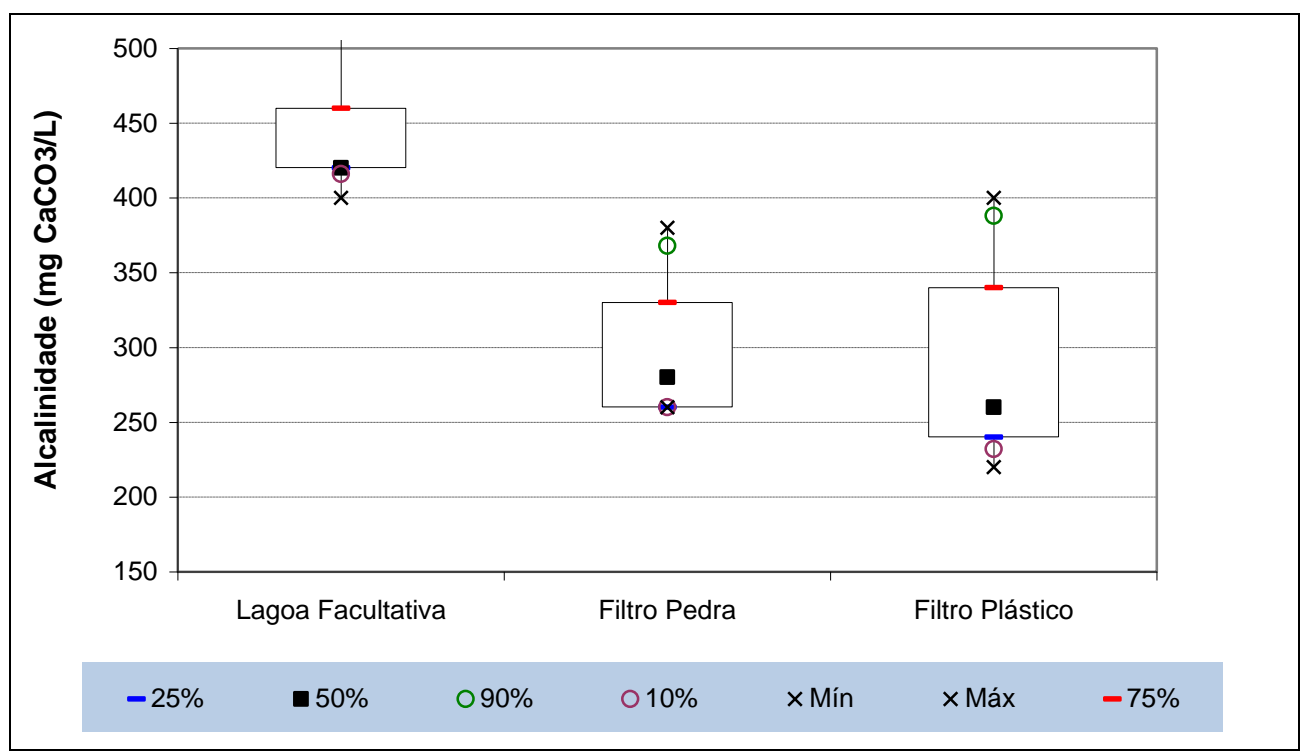

Figura 5.29: Alcalinidade afluente e efluente dos filtros percoladores em escala piloto - ETAPA 03.

De acordo com a figura 5.30, verifica-se que a concentração de oxigênio nos filtros se manteveram em 5,2 mg/l no filtro de pedra e em 5,6 mg/l no filtro de plástico em pelo menos metade das amostras monitoradas. Conforme dito anteriormente, estes valores são suficientes para garantir a nitrificação, não sendo considerado fator limitante. O afluente do filtro biológico manteve $50 \%$ dos valores em $5,0 \mathrm{mg} / \mathrm{L}$, o que demonstra a boa oxigenação do efluente nos filtros percoladores. 


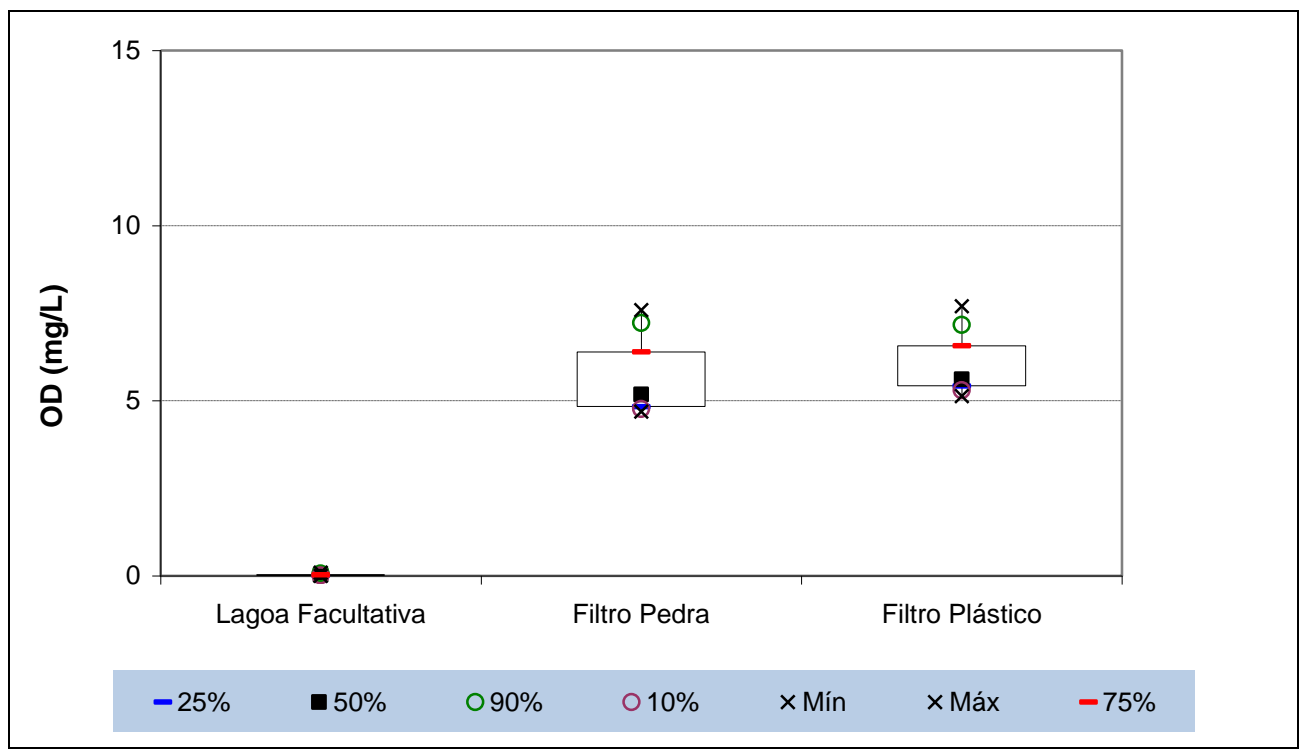

Figura 5.30: Concentração de oxigênio dissolvido afluente e efluente dos filtros percoladores em escala piloto - ETAPA 03

\subsubsection{Formas nitrogenadas - ETAPA 03}

As Figuras 5.31 a 5.34 apresentam a estatística básica das formas nitrogenadas.

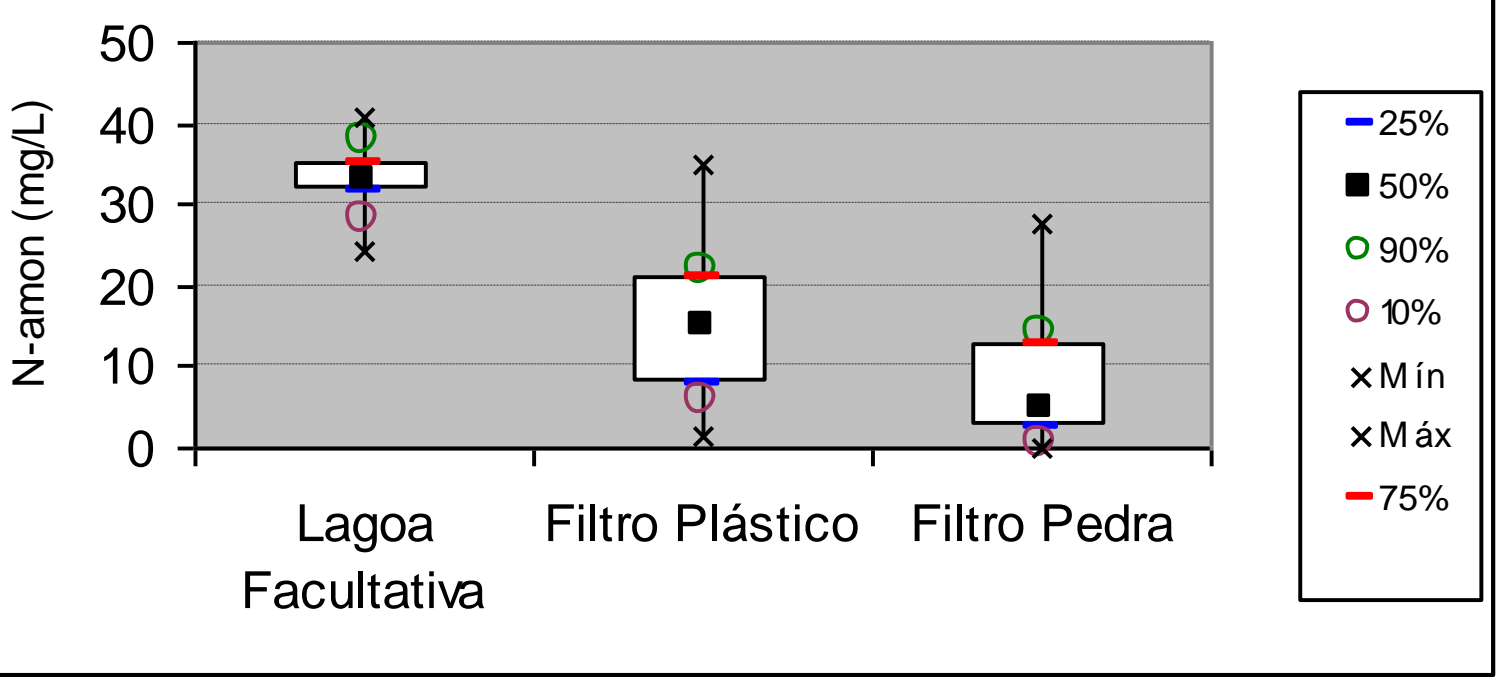



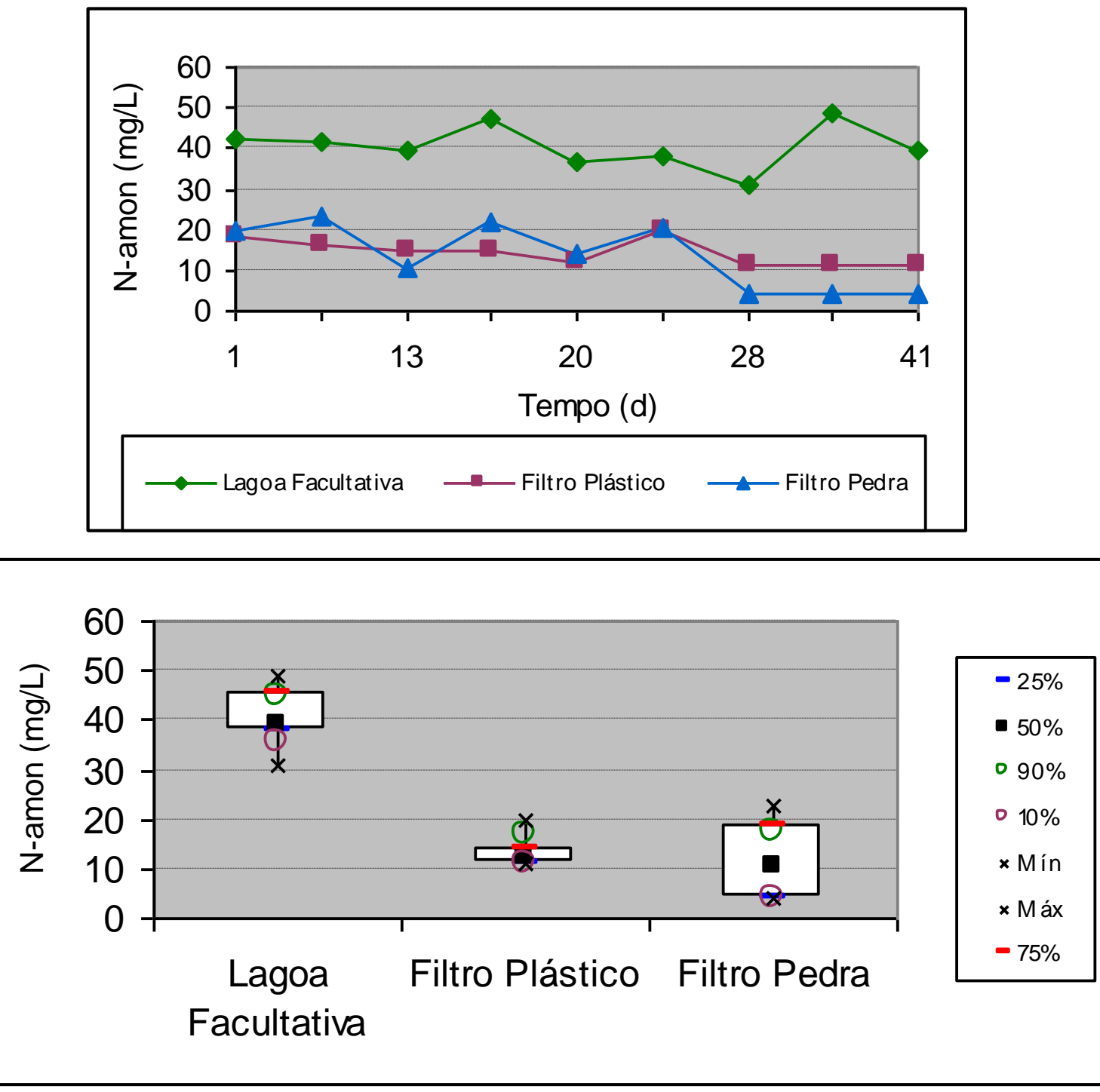

Figura 5.31: Diagrama box-whisker e série histórica de nitrogênio amoniacal ETAPA 03

A remoção do nitrogênio amoniacal foi mais significativa no filtro preenchido com plástico, uma vez ter apresentado em seu efluente final concentração ligeiramente inferior ao apresentado pelo filtro com brita. Apesar de as etapas anteriores terem sido mais eficientes para o filtro com brita, o aumento do biofilme e a maior área superficial apresentada pelos anéis de plástico foram fundamentais para a melhor eficiência apresentada na remoção deste parâmetro do efluente, conforme pode ser verificado na figura 5.32 . 


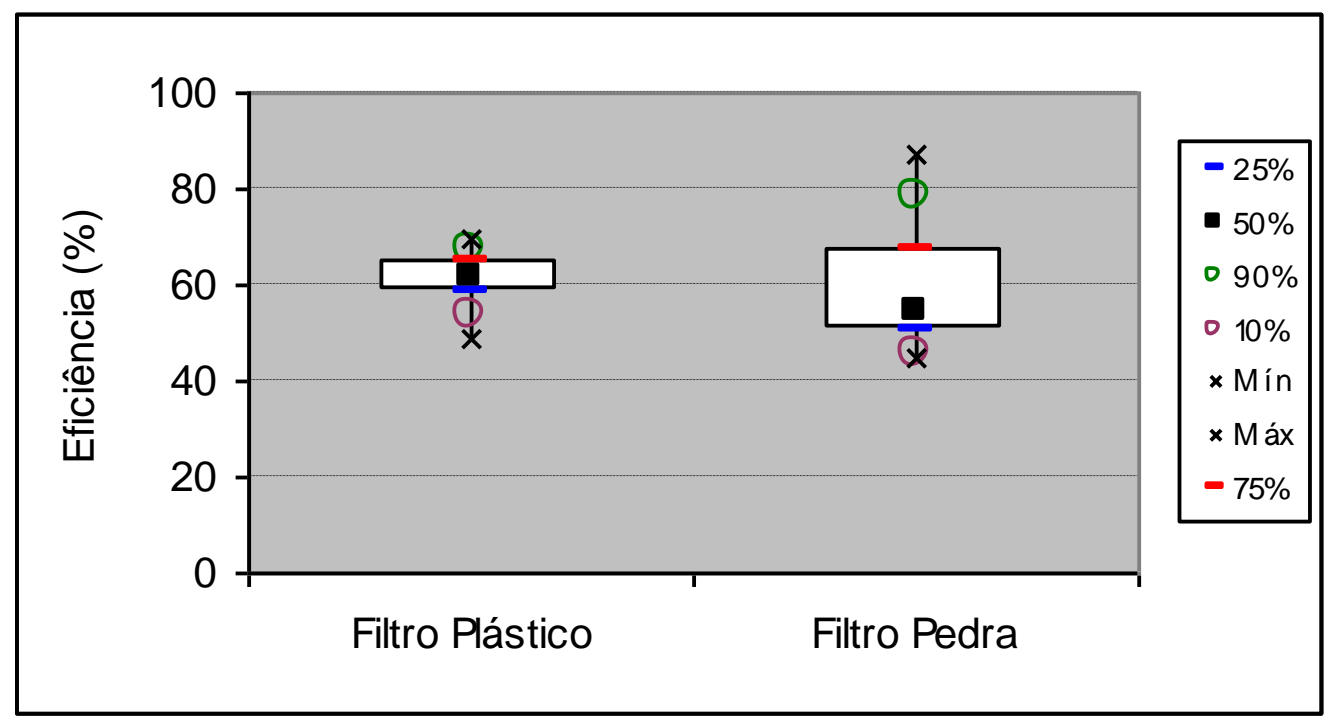

Figura 5.32: Características estatísticas da concentração de nitrogênio amoniacal dos filtros percoladores em escala piloto - ETAPA 03

Em relação ao nitrito, verifica-se na Figura 5.33 que houve pouca concentração de nitrito em ambos os filtros, caracterizando a boa nitrificação realizada pelo sistema. A pequena diferença entre as concentrações nos filtros demonstram que ambos estão trabalhando adequadamente.

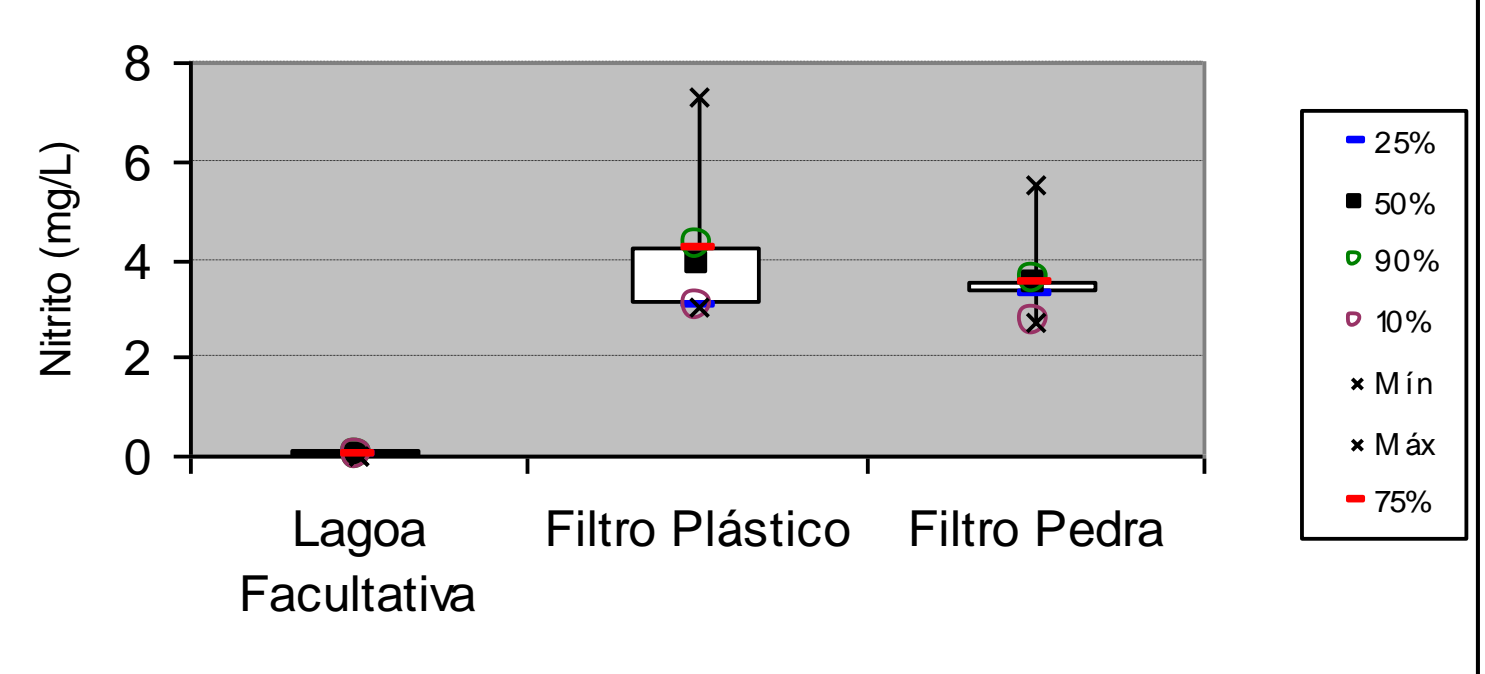




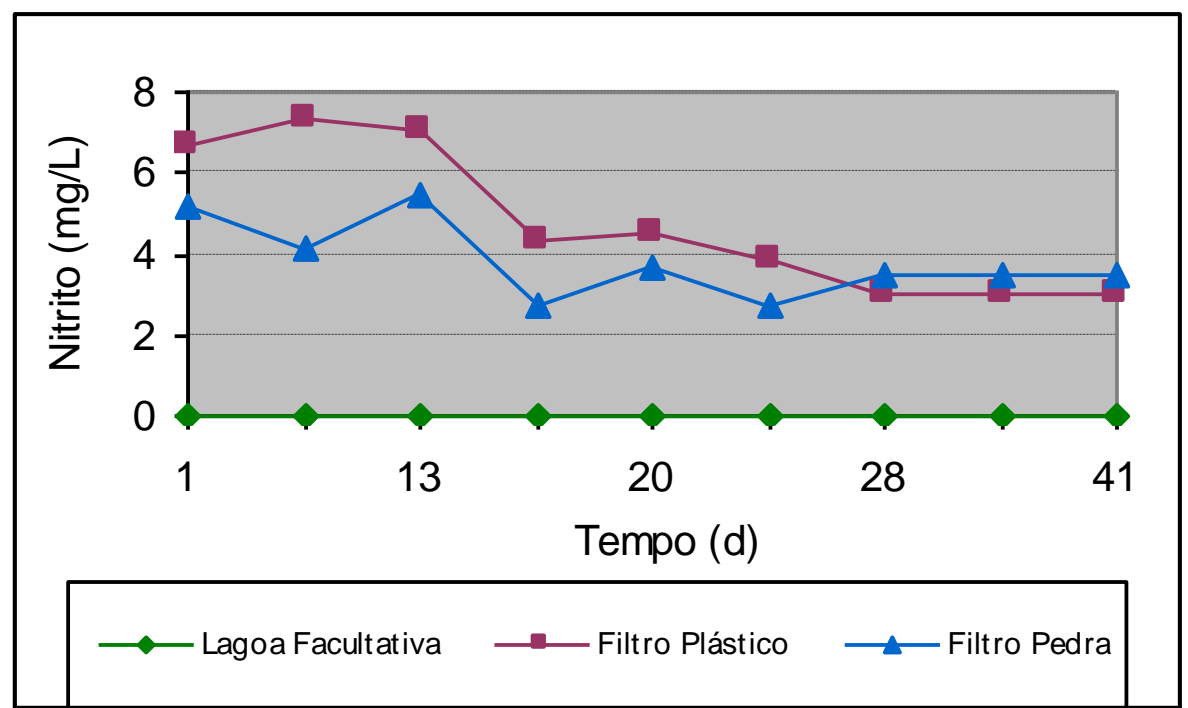

Figura 5.33: Diagrama box-whisker e série histórica de nitrito - ETAPA 03

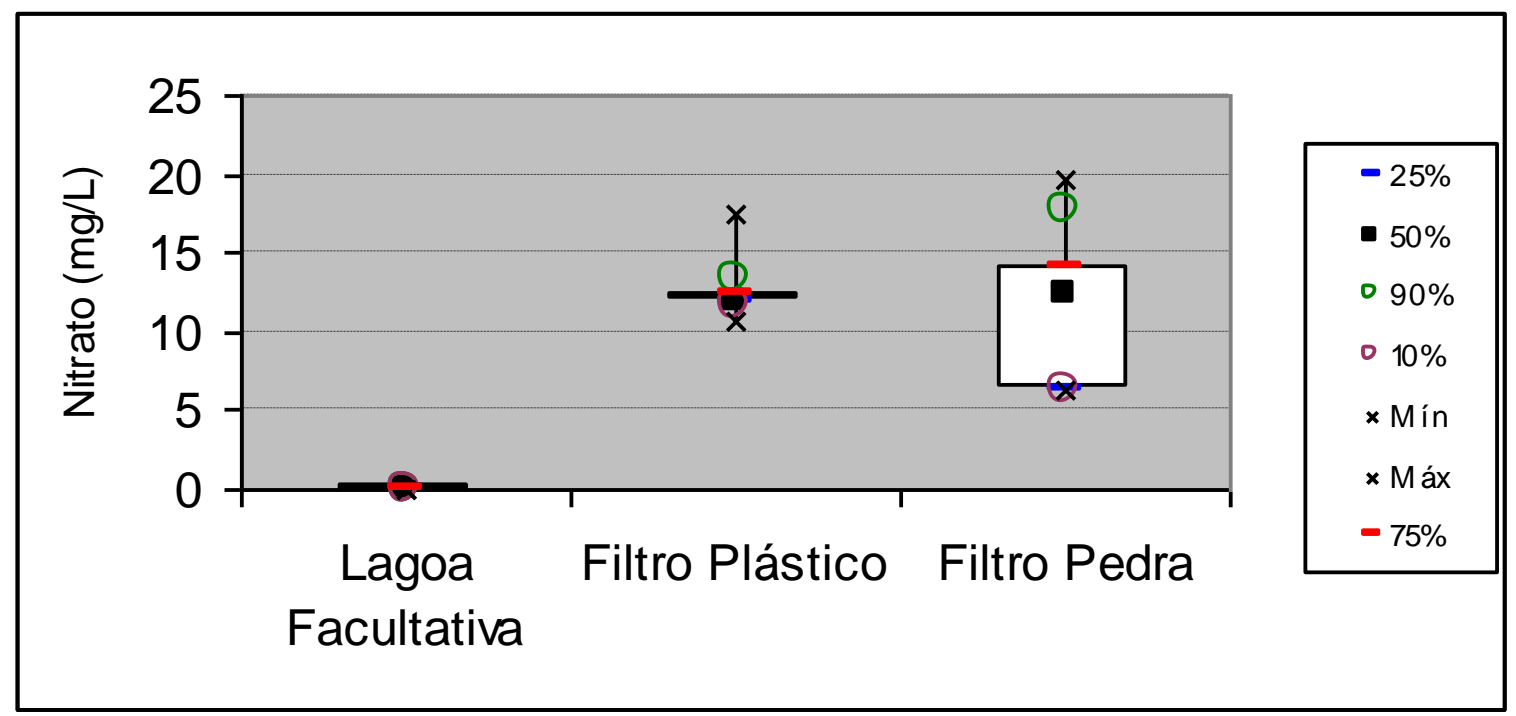




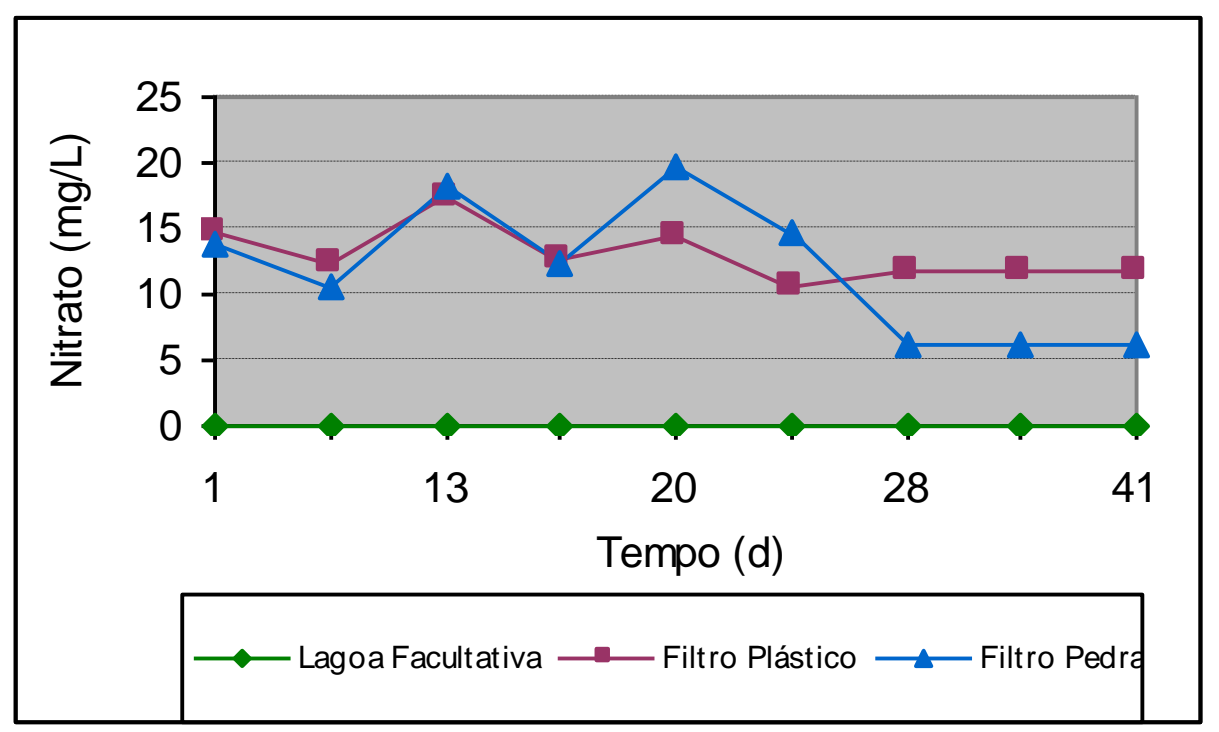

Figura 5.34: Diagrama box-whisker e série histórica de nitrato - ETAPA 03

Nas condições impostas nesta primeira, ambos os filtros também apresentaram condições de reduzir as concentrações de nitrogênio amoniacal para valores abaixo de $20 \mathrm{mg} / \mathrm{L}$, apesar da menor eficiência (60\% no filtro com anéis de plástico) na remoção do nitrogênio em comparação com as duas etapas anteriores. A concentração de nitrato no efluente final de ambos os filtros indica que $\circ \mathrm{pH}$, temperatura e principalmente a concentração de oxigênio estão adequados para a oxidação do nitrito em nitrato e posteriormente na volatilização do nitrogênio pelo processo de desnitrificação.

A maior eficiência apresentada pelo filtro contendo anéis plásticos foi devido à maior superfície para formação de biofilme.

\subsubsection{DQO, DBO e SST - ETAPA 03}

As Figuras 5.36 e 5.37 ilustram respectivamente as séries históricas das concentrações de DQO, DBO e SST da lagoa facultativa e do efluente dos filtros de plástico e pedra, e a tabela 5.3 demonstra a estatística descritiva dos referidos parâmetros. 

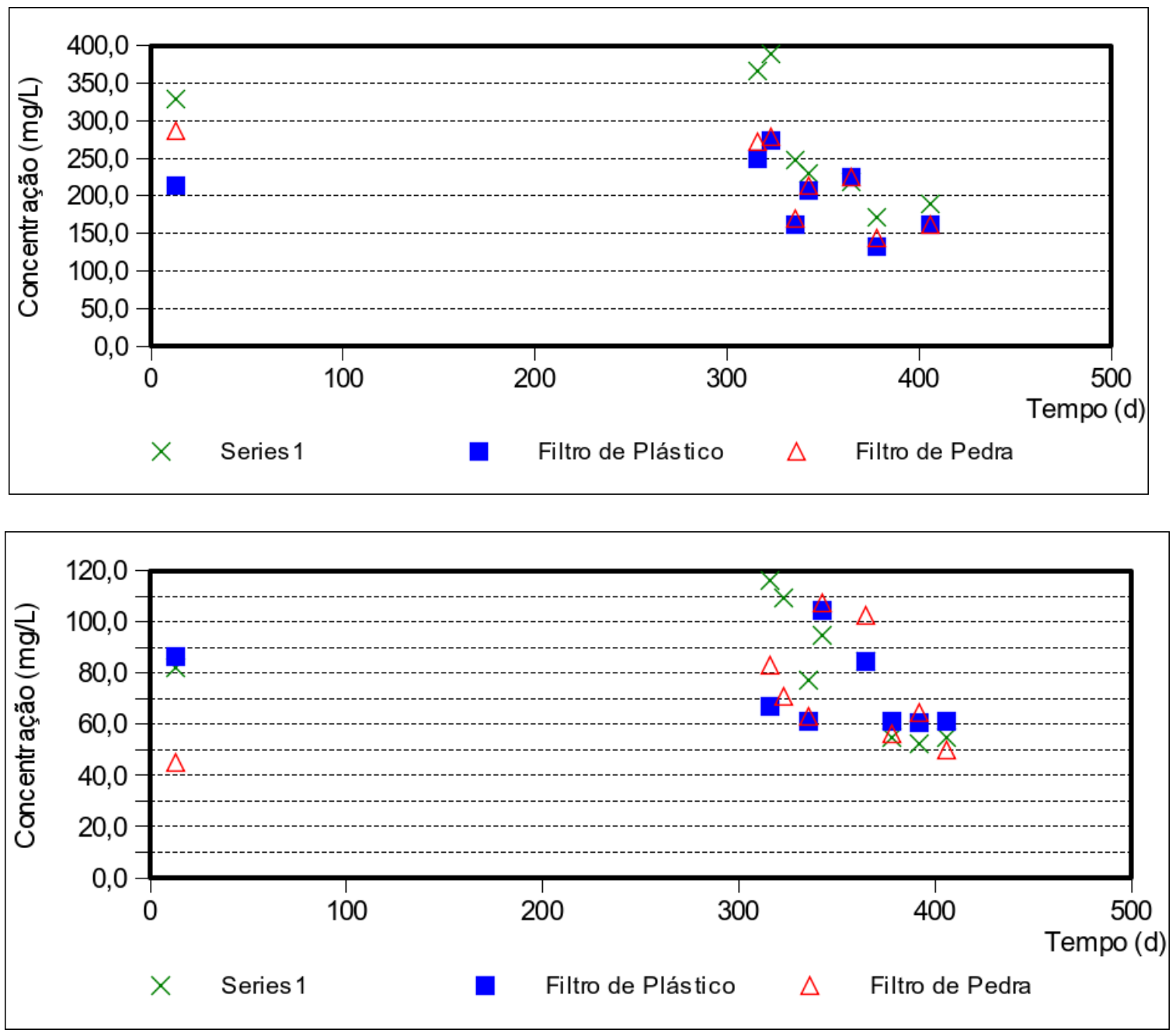

Figura 5.35: Concentrações de DQO e DBO dos efluentes - ETAPA 03.

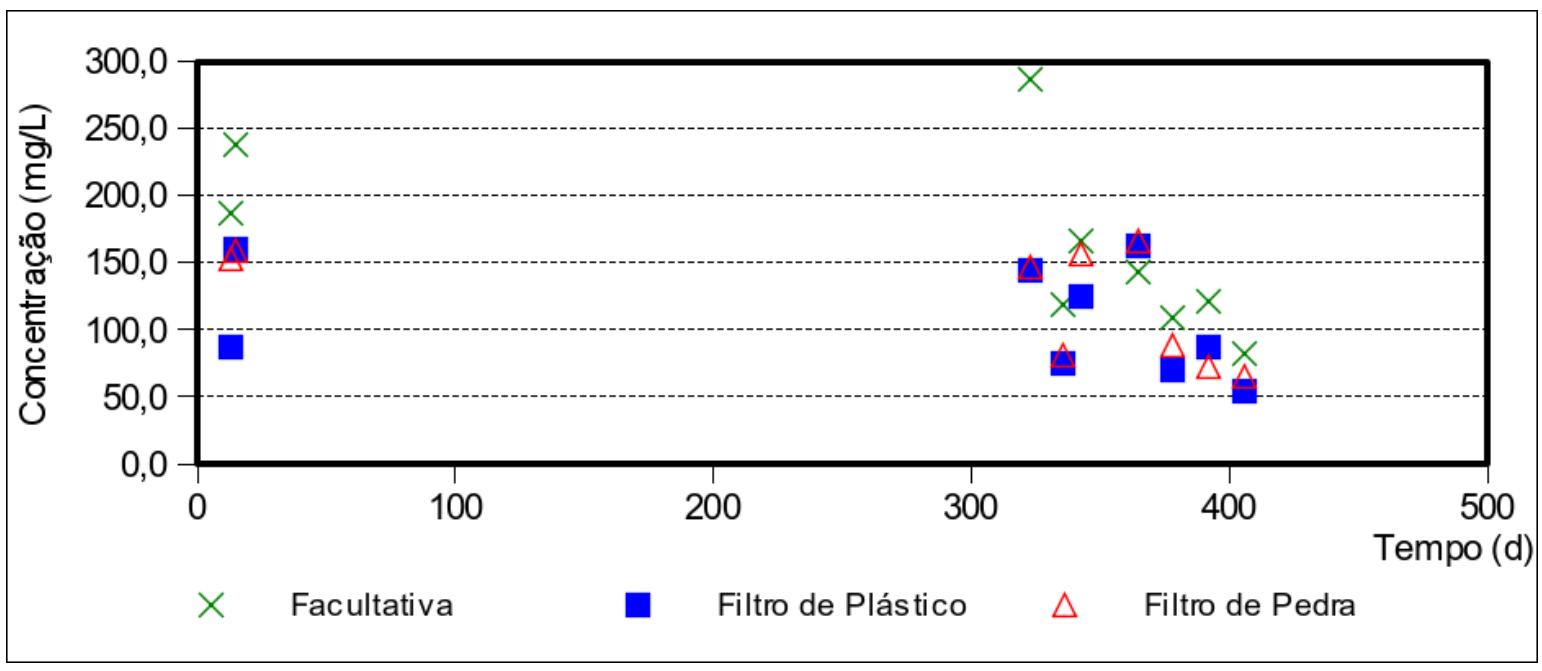

Figura 5.36: Gráfico de dispersão da concentração de sólidos em suspensão totais - ETAPA 03. 
Tabela 5.3: Estatística descritiva dos valores das medianas de DQO, DBO e SST da ETAPA 03.

\begin{tabular}{|l|l|c|c|c|}
\hline & & $\mathrm{DQO}(\mathrm{mg} / \mathrm{L})$ & $\mathrm{DBO}(\mathrm{mg} / \mathrm{L})$ & $\mathrm{SST}(\mathrm{mg} / \mathrm{L})$ \\
\hline \multirow{3}{*}{ Etapa 03 } & Lagoa Facultativa & 240 & 80 & 140 \\
\cline { 2 - 5 } & Filtro Plástico & 210 & 65 & 80 \\
\cline { 2 - 5 } & Filtro Pedra & 220 & 65 & 150 \\
\hline
\end{tabular}

Observa-se na Tabela 5.3 que não ocorre remoção considerável de matéria orgânica nos filtros, demonstrando que a constituição do biofilme é essencialmente voltada à presença de nitrobactérias. É possível que este valor tenha diminuído após os decantadores, não sendo analisado por não ser o foco desta pesquisa.

Observa-se porém considerável remoção dos sólidos no filtro de plástico e, em contrapartida, houve ligeiro aumento na concentração de sólidos no filtro de pedra, podendo ser resultado do desprendimento da biomassa mais antiga aderida às pedras.

Portanto, a utilização do FBP para a remoção do nitrogênio foi suficientemente eficiente apesar do aumento da TAS utilizada nesta etapa.

\subsubsection{Filtros percoladores em escala piloto - ETAPA 04}

Os dois filtros percoladores em escala piloto receberam o efluente da lagoa facultativa, sob as condições operacionais apresentadas nas Figuras $5.37 \mathrm{e}$ 5.38 . 

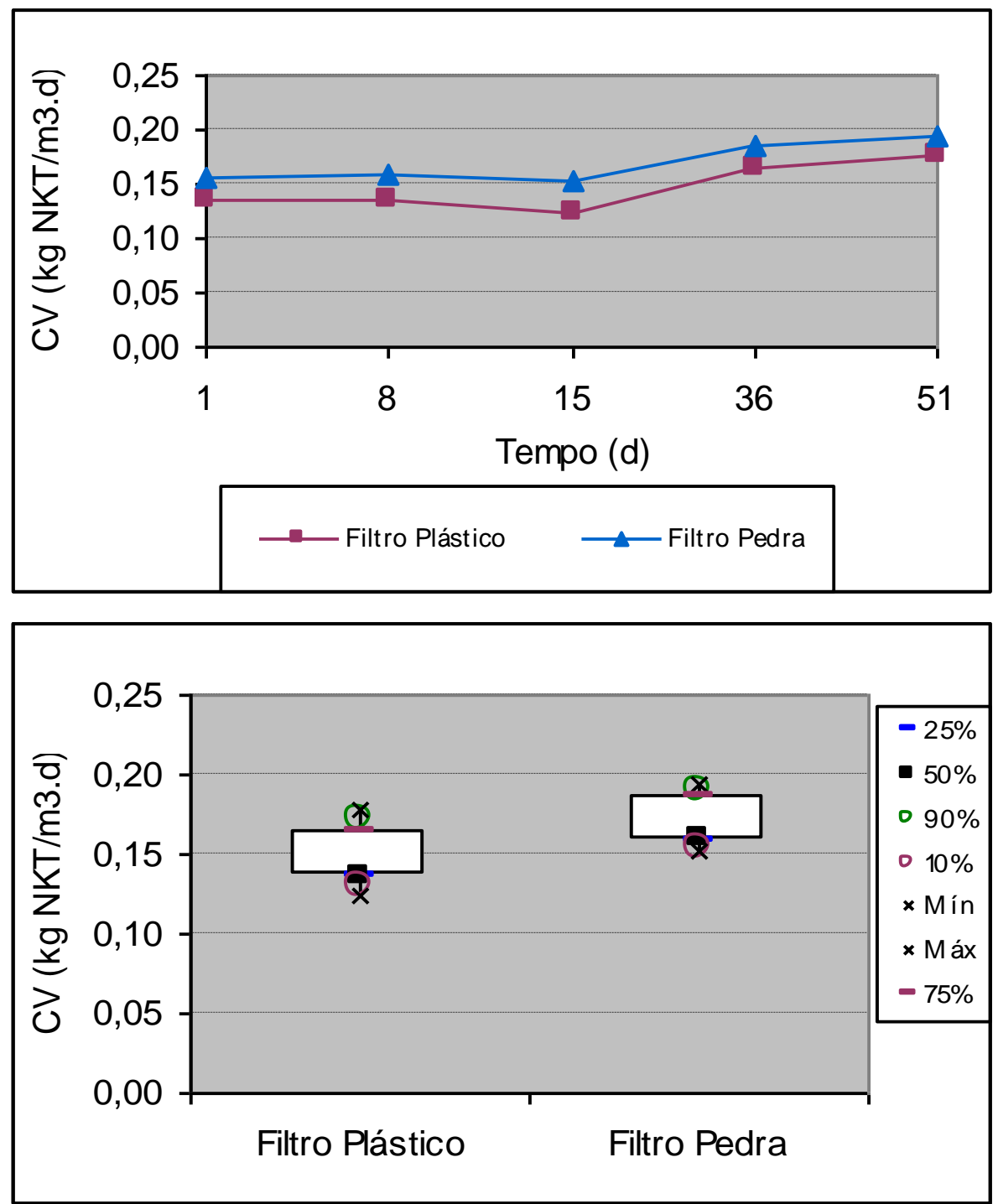

Figura 5.37: Carga volumétrica de NKT - ETAPA 04.

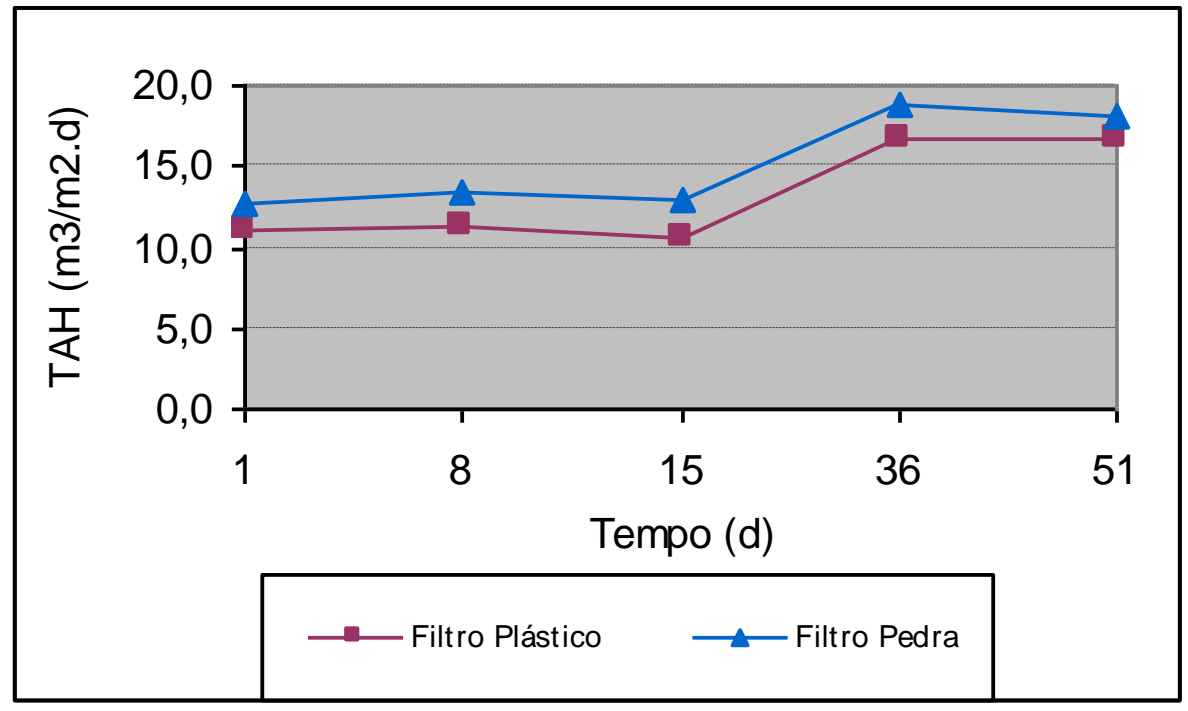




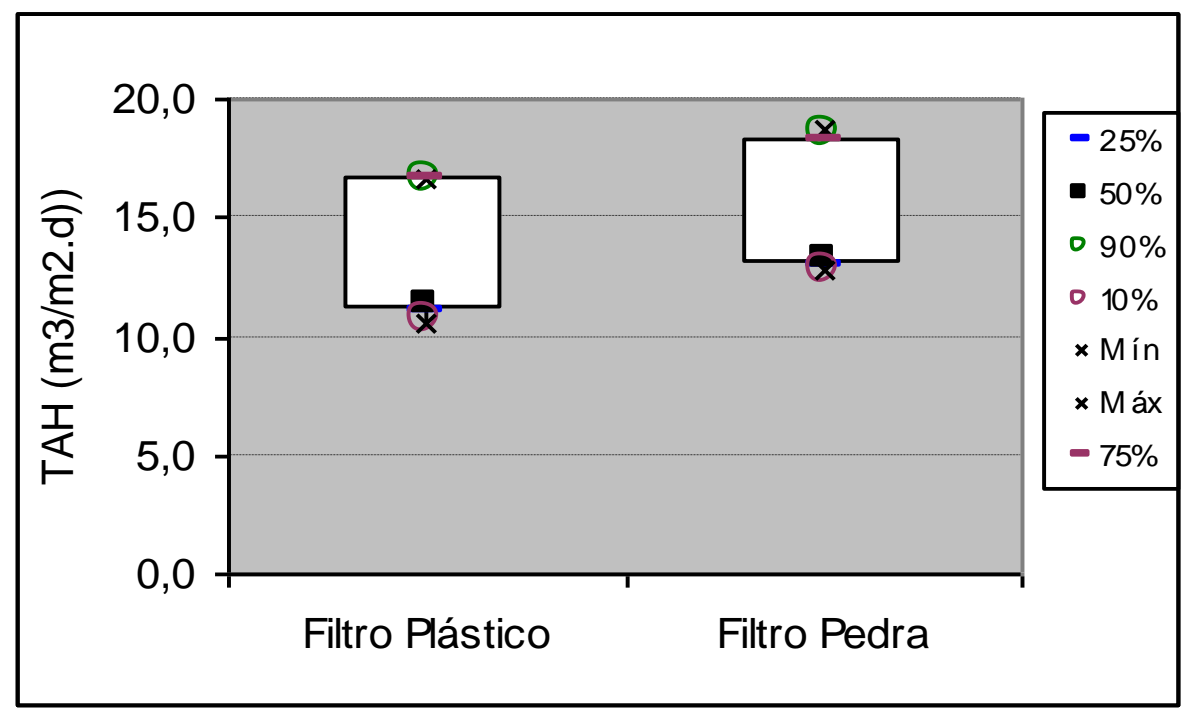

Figura 5.38: Taxa de aplicação hidráulica superficial nos filtros - ETAPA 04

Observa-se que houve uma diferença pequena entre as taxas aplicadas no filtro com leito de pedra e plástico. Cerca de $50 \%$ dos valores ficaram com taxas de $11,4 \mathrm{~m}^{3} / \mathrm{m}^{2}$.d para o filtro de Plástico e $13,3 \mathrm{~m}^{3} / \mathrm{m}^{2} . \mathrm{d}$ para o filtro de Pedra. O que levou a ocorrência desse fato foi que, como o Filtro foi confeccionado em uma única estrutura e dividida ao meio, o peso das pedras com o tempo fez com que a área superficial ficasse maior do seu lado, formando uma espécie de "barriga", e o distribuidor acompanhou este movimento do filtro, fazendo com que o Filtro de Pedra recebesse uma vazão um pouco maior do que a do Filtro de Plástico. Em termos de classificação dos filtros de acordo com a TAS aplicada, essa diferença é pouco significativa, pois de acordo com Metcalf \& Eddy (2003), os filtros de alta taxa trabalham com carga de 10 a $40 \mathrm{~m}^{3} / \mathrm{m}^{2}$.d.

Em termos de carga volumétrica de nitrogênio total Kjedahl, os valores tiveram como mediana os valores de 0,14 $\mathrm{KgNKT} / \mathrm{m}^{3}$.d para o Filtro de Plástico e 0,16 $\mathrm{KgNKT} / \mathrm{m}^{3}$.d para o Filtro de Pedra.

\subsubsection{Eficiência de molhamento dos meios suporte - ETAPA 04}

Os cálculos de eficiência de molhamento da ETAPA 04 são apresentados a seguir: 
- Eficiência de molham ento na Etapa 4 - Filtro Plástico

$\mathrm{Ef}(\%)=\mathrm{TAH} /\left[\mathrm{TAH}+\left(\Gamma^{\times} \mathrm{As}\right)\right]=11,4 /[11,4+(0,113 \times 100)]=50 \%$

- Eficiência de molham ento na Etapa 3 - Filtro Pedra

$E f(\%)=T A H /\left[T A H+\left(\check{x} \times A_{s}\right)\right]=13,3 /[13,3+(0,113 \times 70)]=63 \%$

Os cálculos apresentados demonstram que a taxa de aplicação hidráulica superficial utilizada na Etapa 04 foram suficientes para promover o molhamento de mais de metade de toda a superfície de meio suporte, permitido o molhamento de 50 e $63 \%$ da superfície total dos filtros de Plástico e Pedra, respectivamente.

\subsubsection{Parâmetros de controle - ETAPA 04}

As Figuras 5.39, 5.40, 5.41 e 5.42 apresentam uma estatística dos parâmetros de controle, como pH, temperatura, alcalinidade e concentração de oxigênio dissolvido dos efluentes.

Durante a etapa 04, observou-se que a mediana dos resultados de $\mathrm{pH}$ monitorados nos efluentes dos filtros de pedra e de plástico estiveram na faixa de 7,9 , enquanto que o afluente apresentou valores de 7,7. Altos valores de $\mathrm{pH}$ facilitam a oxidação direta da amônia livre para nitrato, enquanto que baixos valores de $\mathrm{pH}$ ou mesmo próximos à neutralidade são ruins para o processo de nitrificação, pois inibem a ação das nitrossomas e nitrobacters pelo acúmulo de amônia ionizada. 


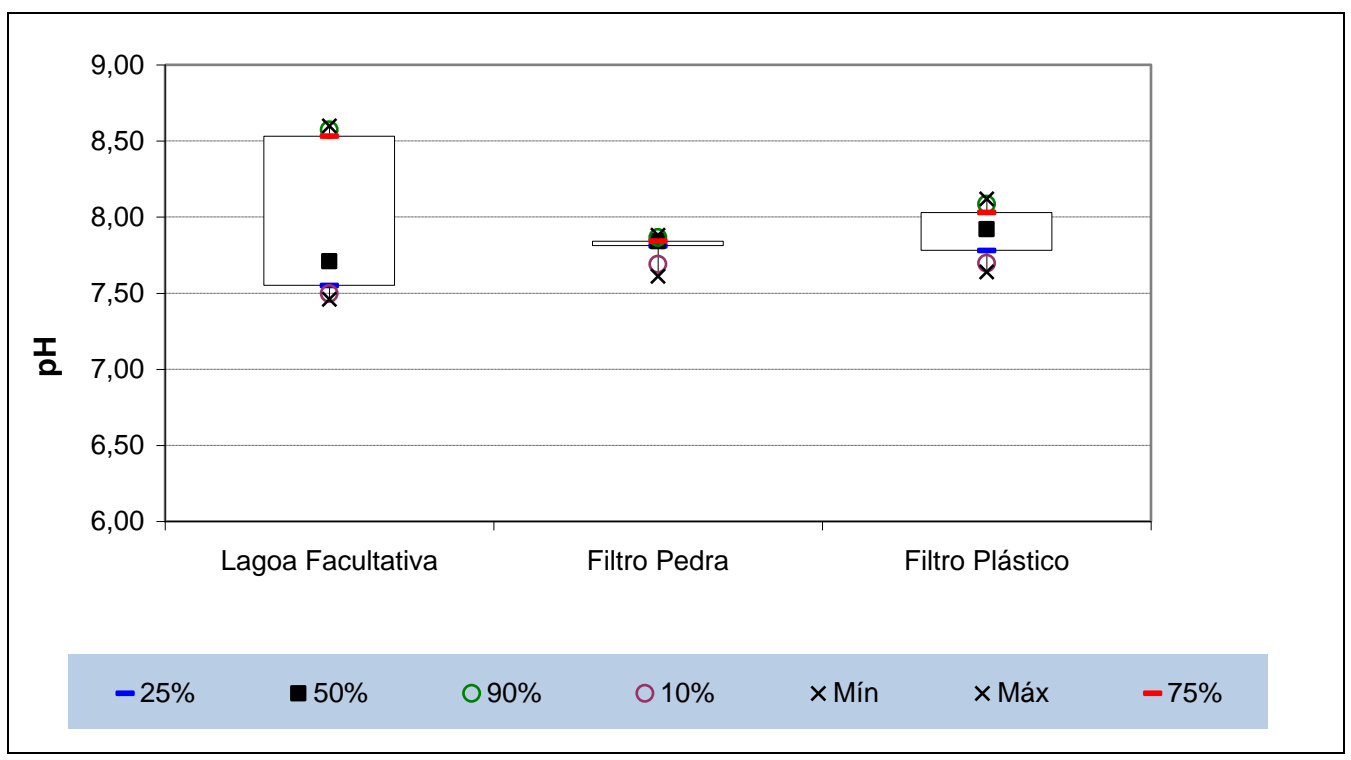

Figura 5.39: $\mathrm{pH}$ afluente e efluente dos filtros percoladores em escala piloto - ETAPA 04.

Os valores de temperatura mantiveram na faixa de $28^{\circ} \mathrm{C}$ em ambos os filtros e na Lagoa Facultativa, apesar da temperatura do ar se manter na faixa de $32^{\circ} \mathrm{C}$. Altas temperaturas do meio líquido propiciam a nitrificação, auxiliando na remoção do nitrogênio.

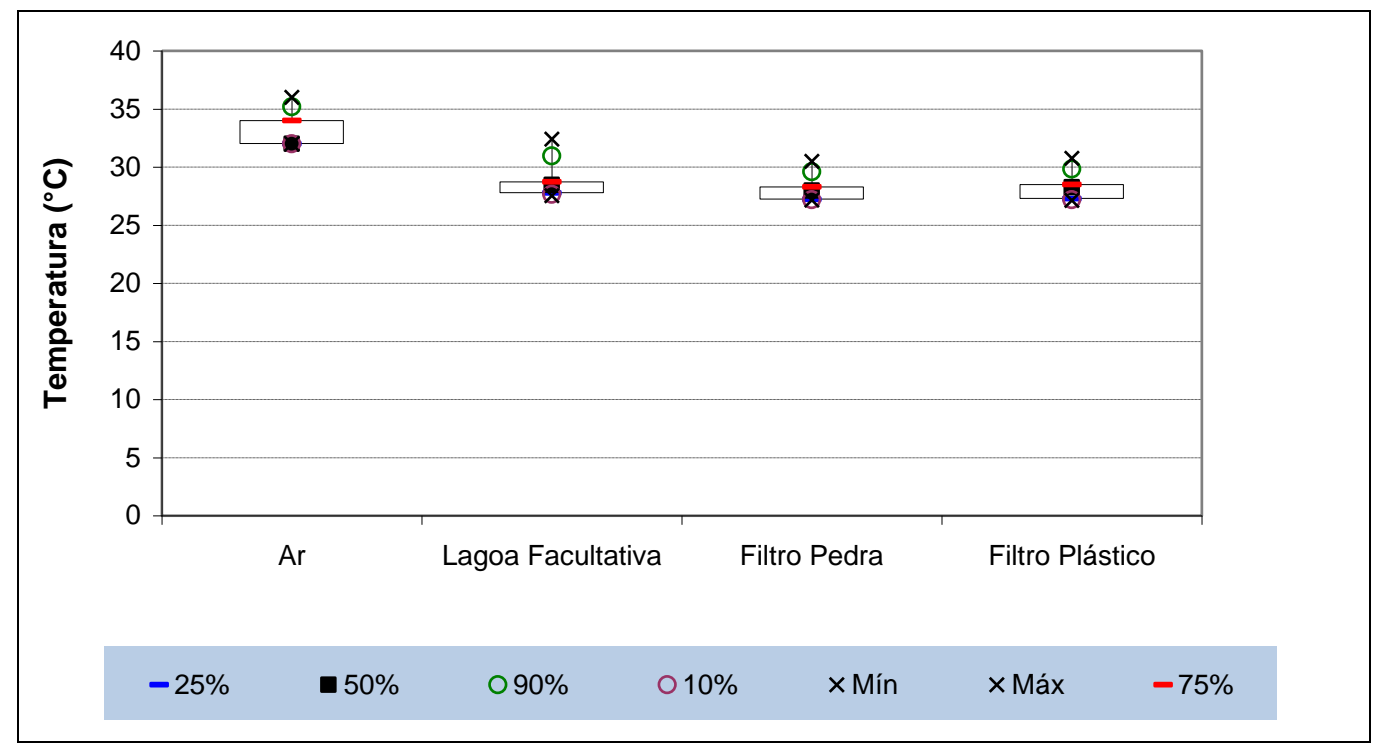

Figura 5.40: Temperatura afluente e efluente dos filtros percoladores em escala piloto - ETAPA 04

Quanto a alcalinidade, a mediana dos valores obtidos no filtro de pedra estiveram na ordem de $200 \mathrm{mg} / \mathrm{L}$, enquanto que no filtro de plástico, a alcalinidade esteve em $260 \mathrm{mg} / \mathrm{L}$, igual ao apresentado na Etapa 3. Tais 
resultados foram inferiores ao verificado no afluente, o qual se apresentou com $360 \mathrm{mg} / \mathrm{L}$. Como a queda de alcalinidade está associada à nitrificação, pode-se dizer que houve maior grau de nitrificação no filtro preenchido com brita, conforme será verificado na análise das séries nitrogenadas no subitem 5.1.4.3 - Formas Nitrogenadas - ETAPA 4.

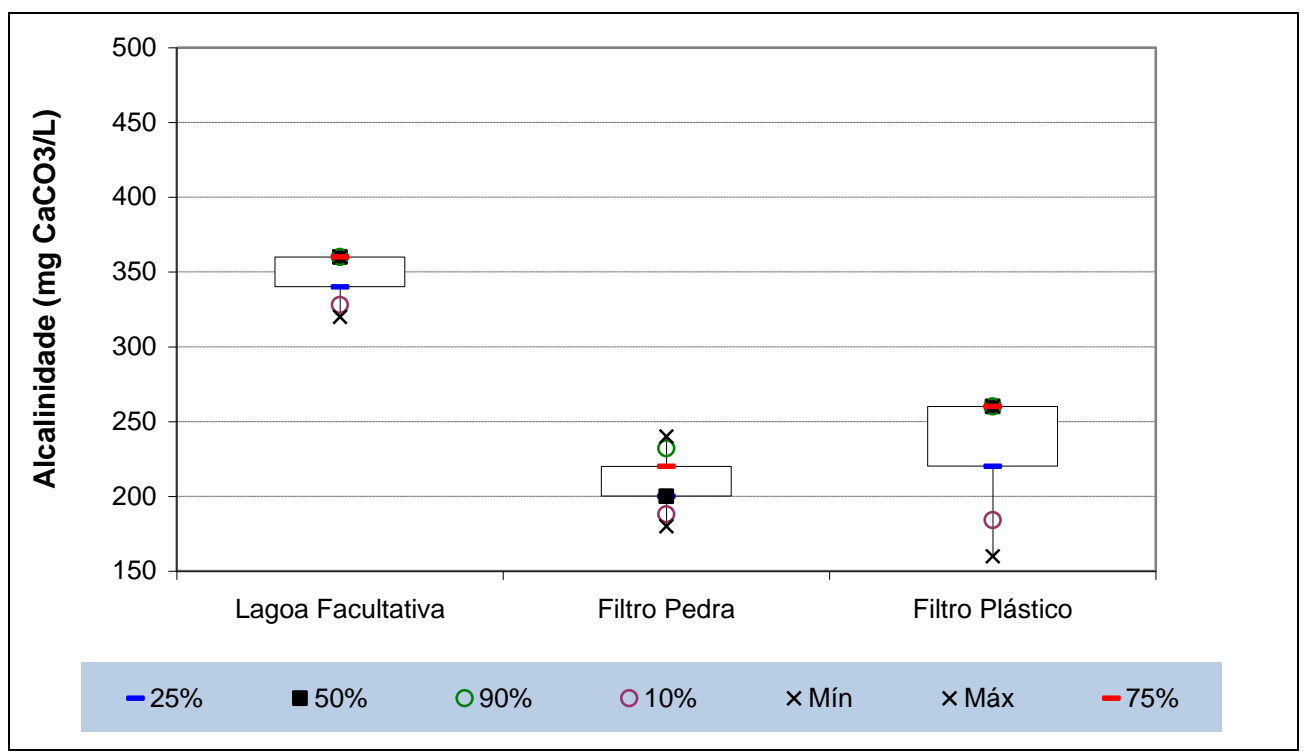

Figura 5.41: Alcalinidade afluente e efluente dos filtros percoladores em escala piloto - ETAPA 04

De acordo com a Figura 5.42, verifica-se que a concentração de oxigênio nos filtros se manteve em 4,3 mg/l no Filtro de Pedra e em 4,2 mg/l no Filtro de Plástico em valores medianos. Conforme dito anteriormente, estes valores são suficientes para garantir a nitrificação, não sendo considerado fator limitante, porém, foram inferiores ao apresentado em todas as etapas anteriores. $\mathrm{O}$ afluente do filtro biológico manteve $50 \%$ dos valores em 2,7 $\mathrm{mg} / \mathrm{L}$ e, apesar de ter aumentado no FBP, verifica-se que o aumento não foi significativo. 


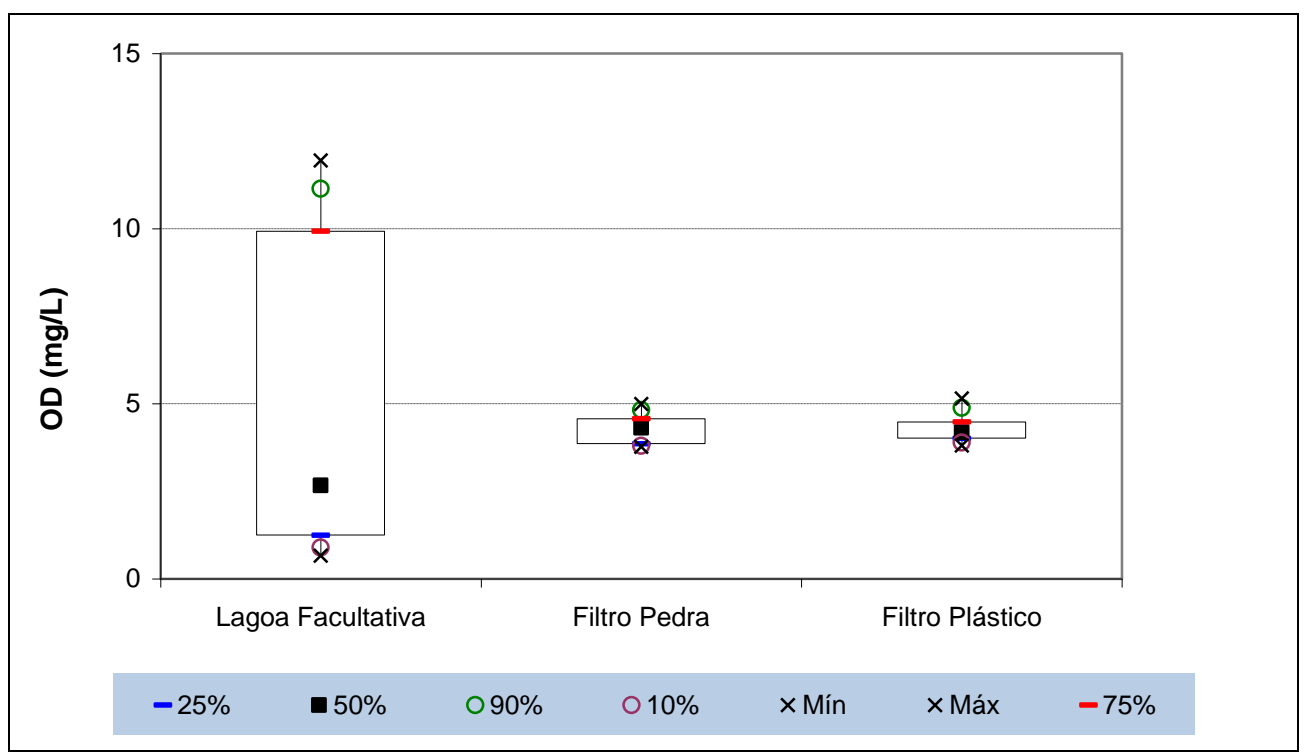

Figura 5.42: Concentração de oxigênio dissolvido afluente e efluente dos filtros percoladores em escala piloto - ETAPA 04.

\subsubsection{Formas nitrogenadas - ETAPA 04}

As Figuras 5.43 a 5.46 apresentam a estatística básica das formas nitrogenadas.

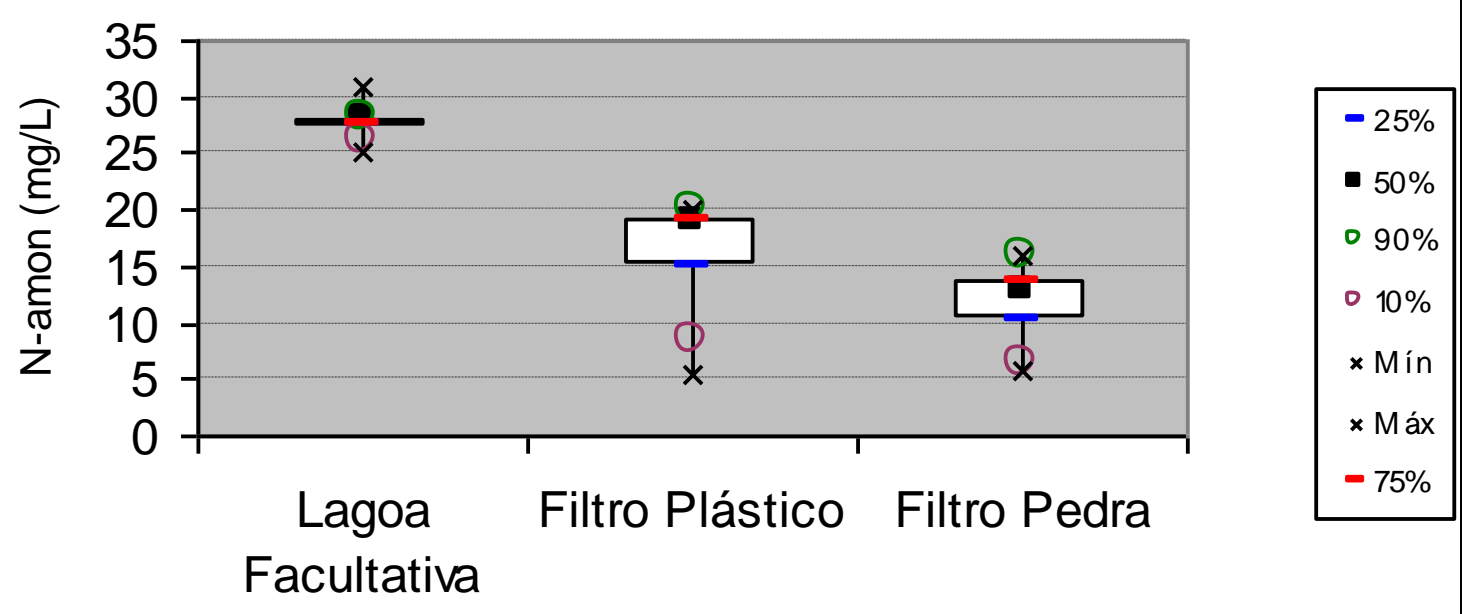




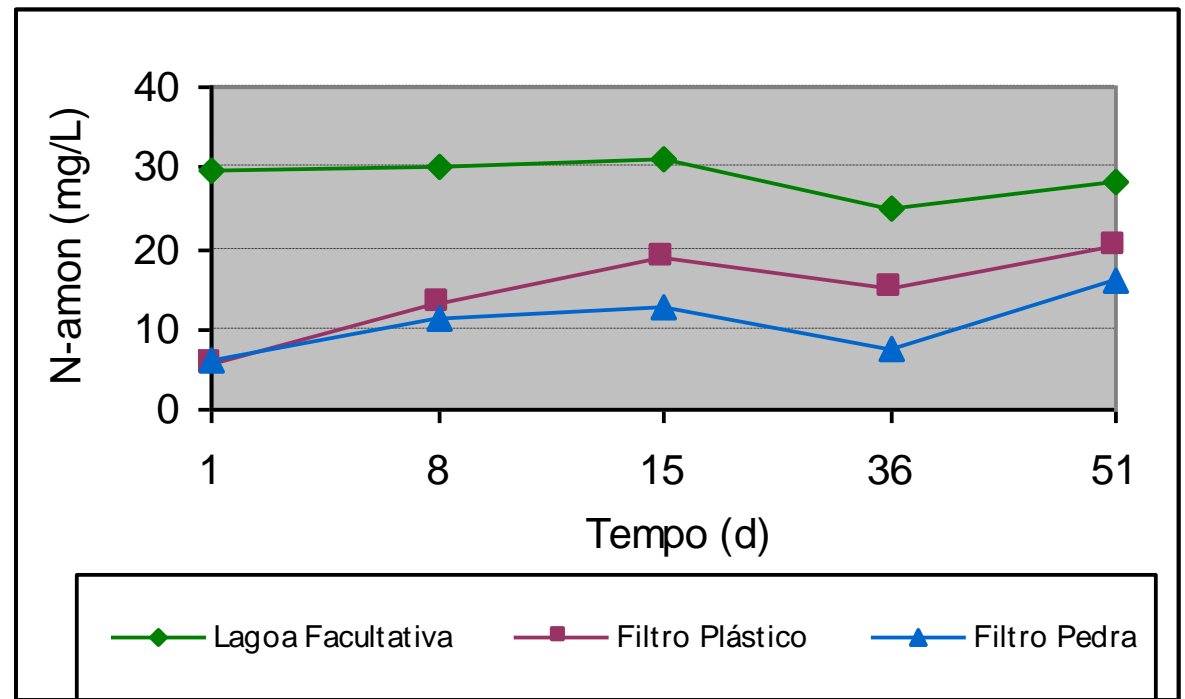

Figura 5.43: Diagrama box-whisker e série histórica de nitrogênio amoniacal ETAPA 04

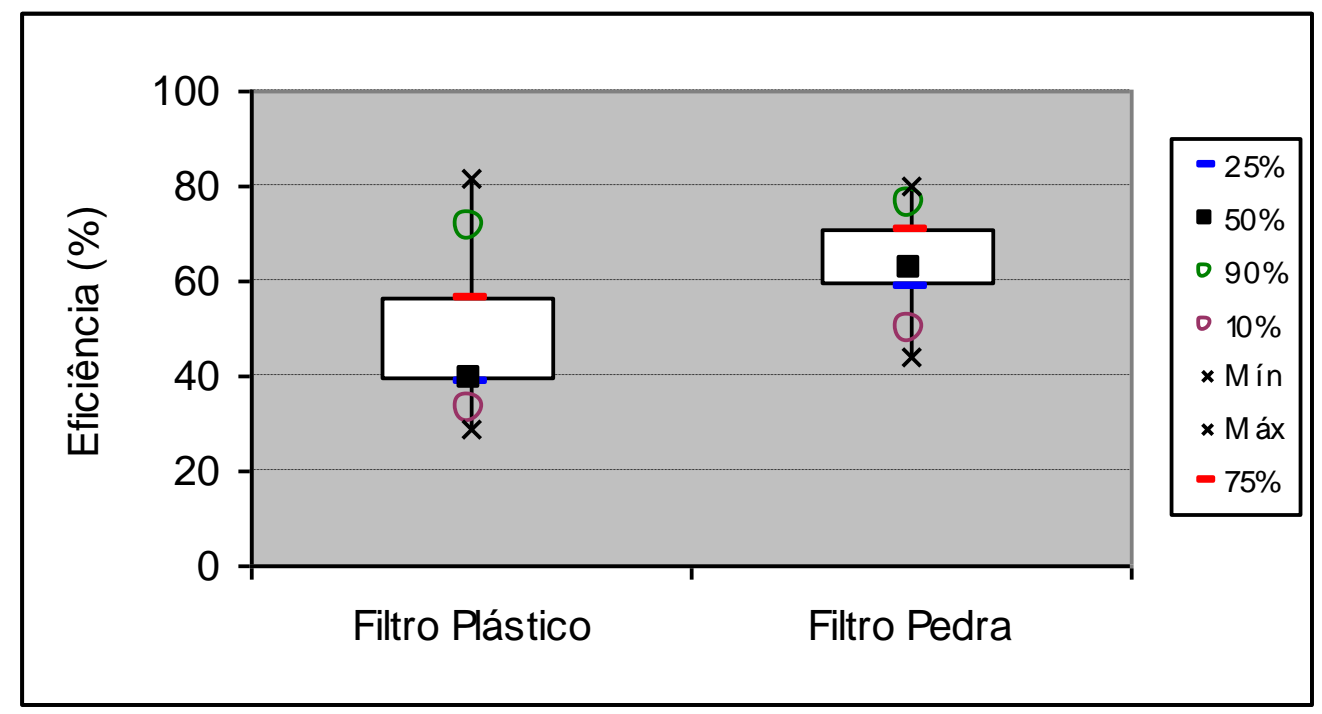

Figura 5.44: Características estatísticas da concentração de nitrogênio amoniacal dos filtros percoladores em escala piloto ETAPA 04.

A remoção do nitrogênio amoniacal foi mais significativo no filtro preenchido com brita, uma vez ter apresentado em seu efluente final concentração mediana de 12,9 mg/l, enquanto que no filtro com anéis de plástico, a concentração esteve em $19 \mathrm{mg} / \mathrm{l}$. Apesar da menor área superficial, a eficiência do filtro contendo brita foi $20 \%$ maior do que a eficiência apresentada pelo filtro com anéis plásticos, conforme demonstrado na Figura 5.44. 

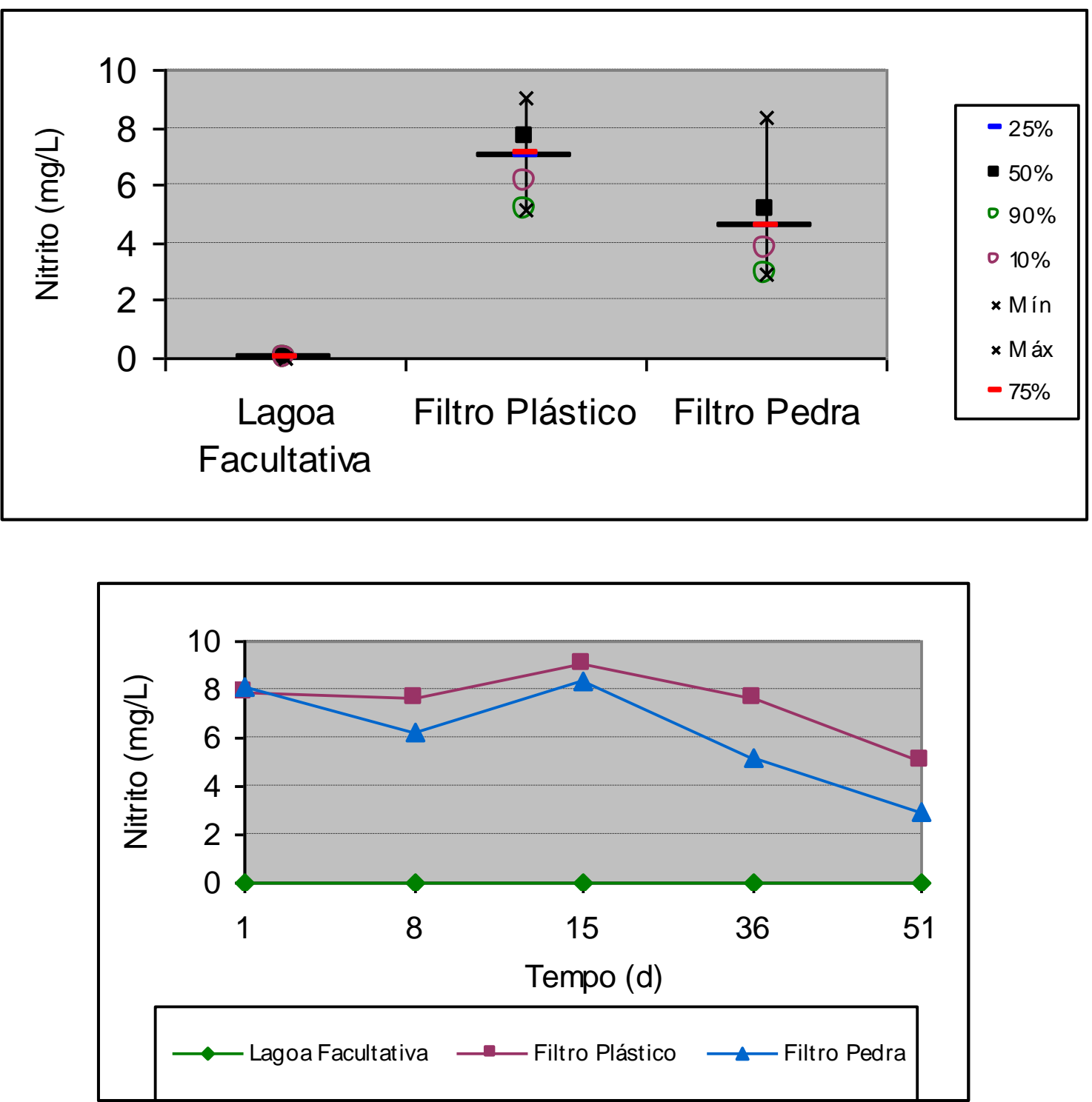

Figura 5.45: Diagrama box-whisker e série histórica de nitrito - ETAPA 04

Em relação ao nitrito, verifica-se pela figura 5.45 que houve ligeiro aumento da concentração em relação à Etapa 3, principalmente no filtro com anéis plásticos, demonstrando ter ocorrido acúmulo de nitrito e problemas para concretização da nitrificação. Já os valores de nitrito apresentados no filtro com brita estiveram satisfatórios, demonstrando haver a constante nitrificação. 

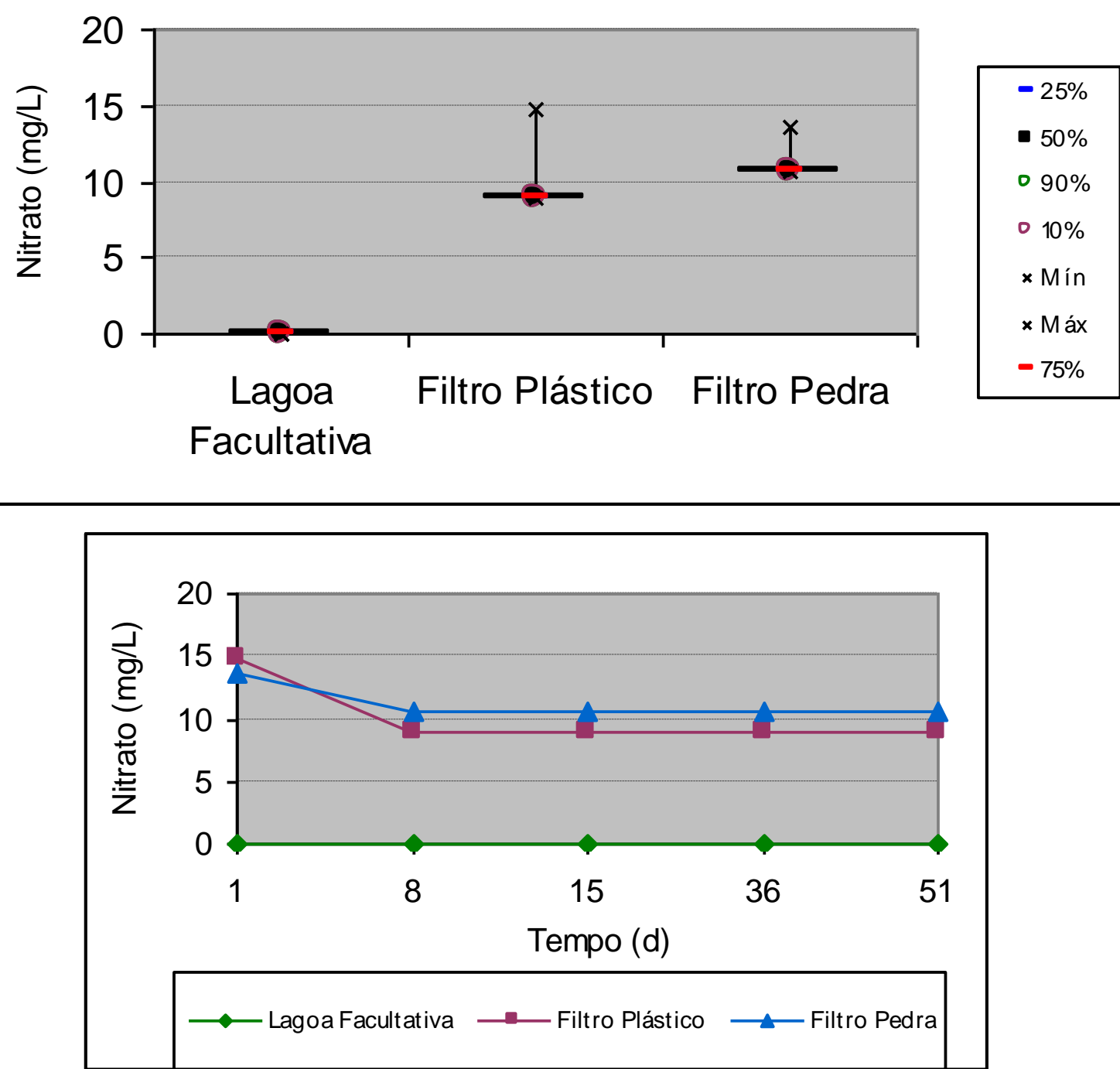

Figura 5.46: Diagrama box-whisker e série histórica de nitrato - ETAPA 04

Nas condições impostas nesta etapa, ambos os filtros também apresentaram condições de reduzir as concentrações de nitrogênio amoniacal para valores abaixo de $20 \mathrm{mg} / \mathrm{L}$, apesar da alta concentração obtida no filtro com anéis plásticos. A baixa concentração de oxigênio no efluente pode ter sido fator importante para diminuição do processo de nitrificação, apesar desta concentração ser superior aos $2 \mathrm{mg} / \mathrm{l}$ recomendados pela literatura.

Novamente a eficiência na remoção de nitrogênio ocorreu no filtro com brita, demonstrando sua maior capacidade de formação de biofilme e redução do nitrogênio do esgoto sanitário. 


\subsubsection{DQO, DBO e SST - ETAPA 04}

As Figuras 5.47 e 5.48 ilustram respectivamente as séries históricas das concentrações de DQO, DBO e SST da Lagoa Facultativa e do efluente dos Filtros de Plástico e Pedra, e a tabela 5.4 demonstra a estatística descritiva dos referidos parâmetros.
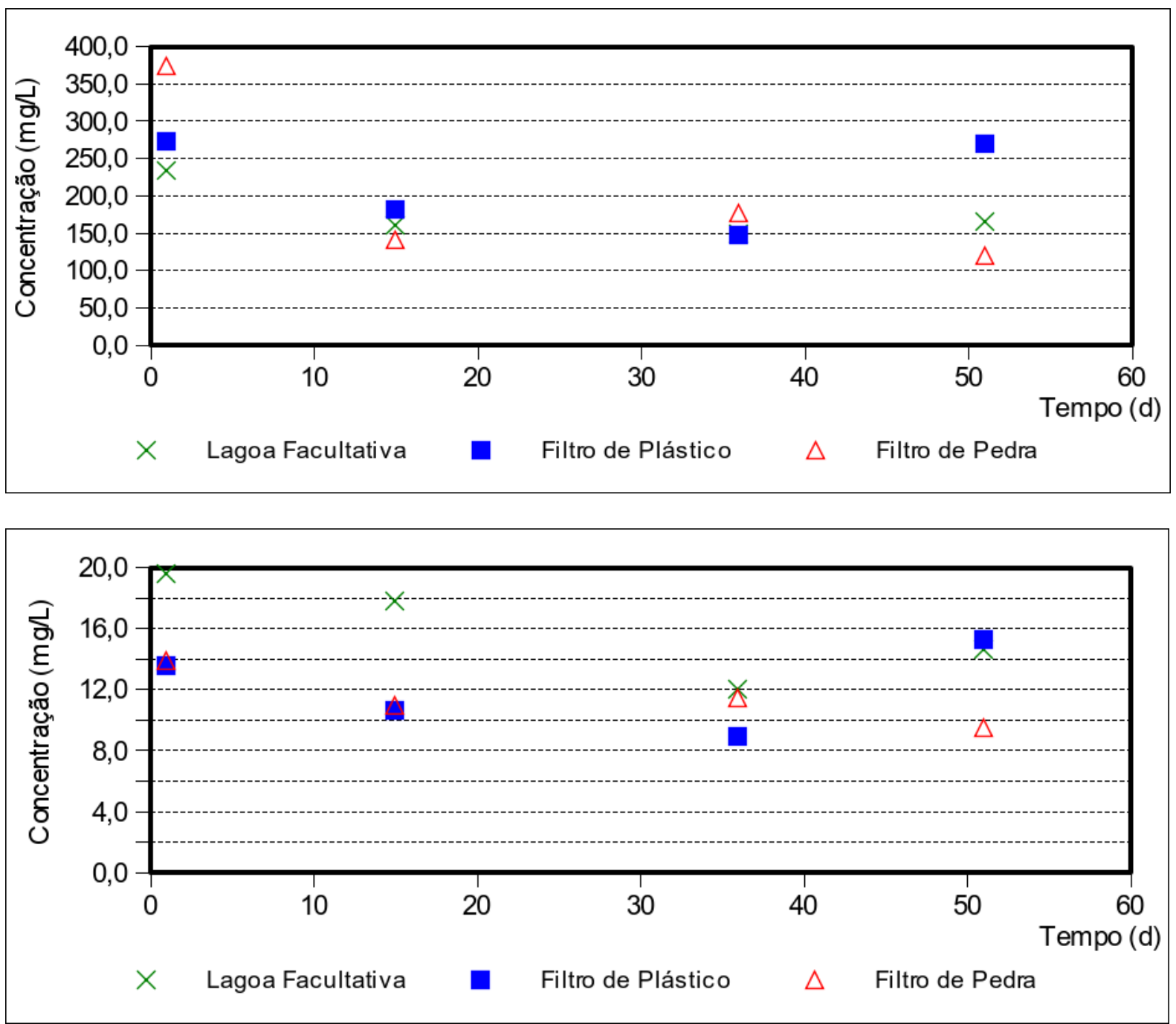

Figura 5.47: Concentrações de DQO e DBO dos efluentes - ETAPA 04 


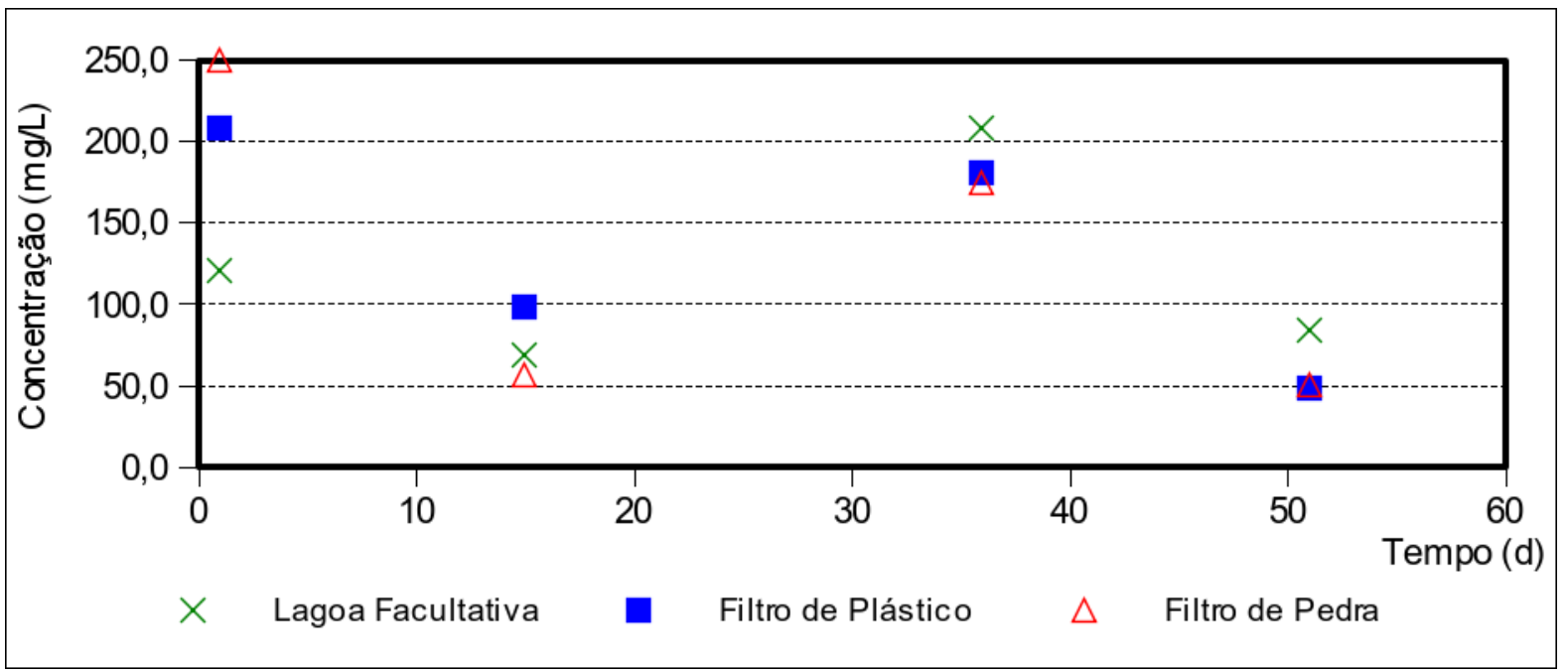

Figura 5.48: Gráfico de dispersão da concentração de sólidos em suspensão totais - ETAPA 04

Tabela 5.4: Estatística descritiva dos valores das medianas de DQO, DBO e SST da ETAPA 04

\begin{tabular}{|l|l|c|c|c|}
\hline & & $\mathrm{DQO}(\mathrm{mg} / \mathrm{L})$ & $\mathrm{DBO}(\mathrm{mg} / \mathrm{L})$ & $\mathrm{SST}(\mathrm{mg} / \mathrm{L})$ \\
\hline \multirow{3}{*}{ Etapa 04 } & Lagoa Facultativa & 190 & 55 & 140 \\
\cline { 2 - 5 } & Filtro Plástico & 220 & 100 & 150 \\
\cline { 2 - 5 } & Filtro Pedra & 190 & 100 & 80 \\
\hline
\end{tabular}

Observa-se pela Tabela 5.4 que houve aumento na concentração de matéria orgânica no efluente. É possível que este valor tenha diminuído após os decantadores, não sendo analisado por não ser o foco desta pesquisa.

Observa-se porém considerável remoção dos sólidos no filtro de pedra e, em contrapartida, houve ligeiro aumento na concentração de sólidos no filtro de plástico.

Portanto, a utilização do FBP para a remoção do nitrogênio foi suficientemente eficiente apesar do aumento da TAS utilizada nesta etapa, porém o aumento da DBO no efluente final não foi considerado satisfatório. 


\subsection{Comparação entre as Etapas e discussões de resultados}

As Figuras 5.49 e 5.50 apresentam os percentis das concentrações de $\mathrm{N}^{-\mathrm{NH}_{3}}$ afluentes e efluentes aos FBPs e as eficiências de remoção de $\mathrm{N}-\mathrm{NH}_{3}$ das quatro etapas, respectivamente.

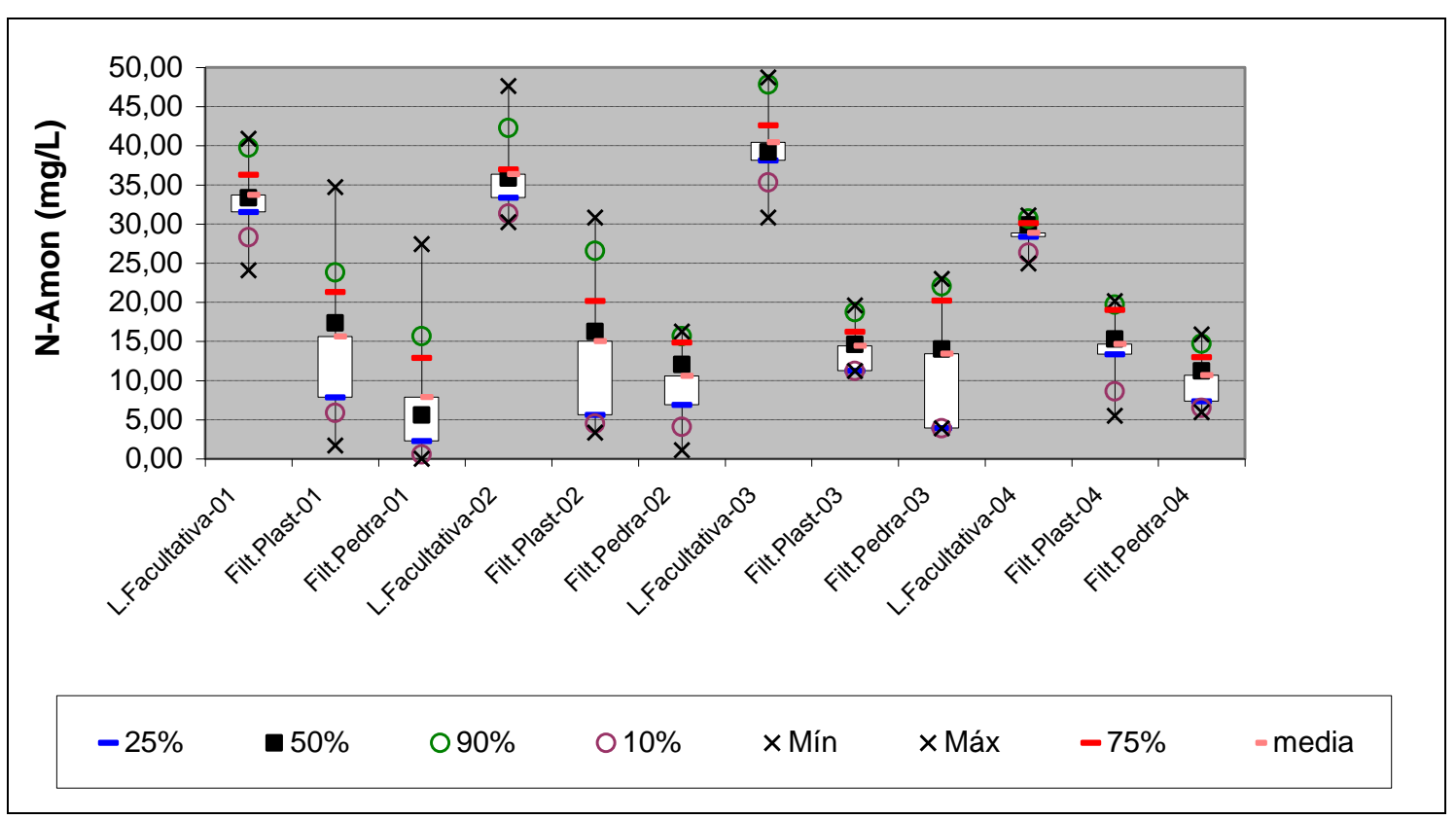

Figura 5.49: Box \& Whiskers das concentrações de $\mathrm{N}-\mathrm{NH}_{3}$ afluentes e efluentes aos FBPs

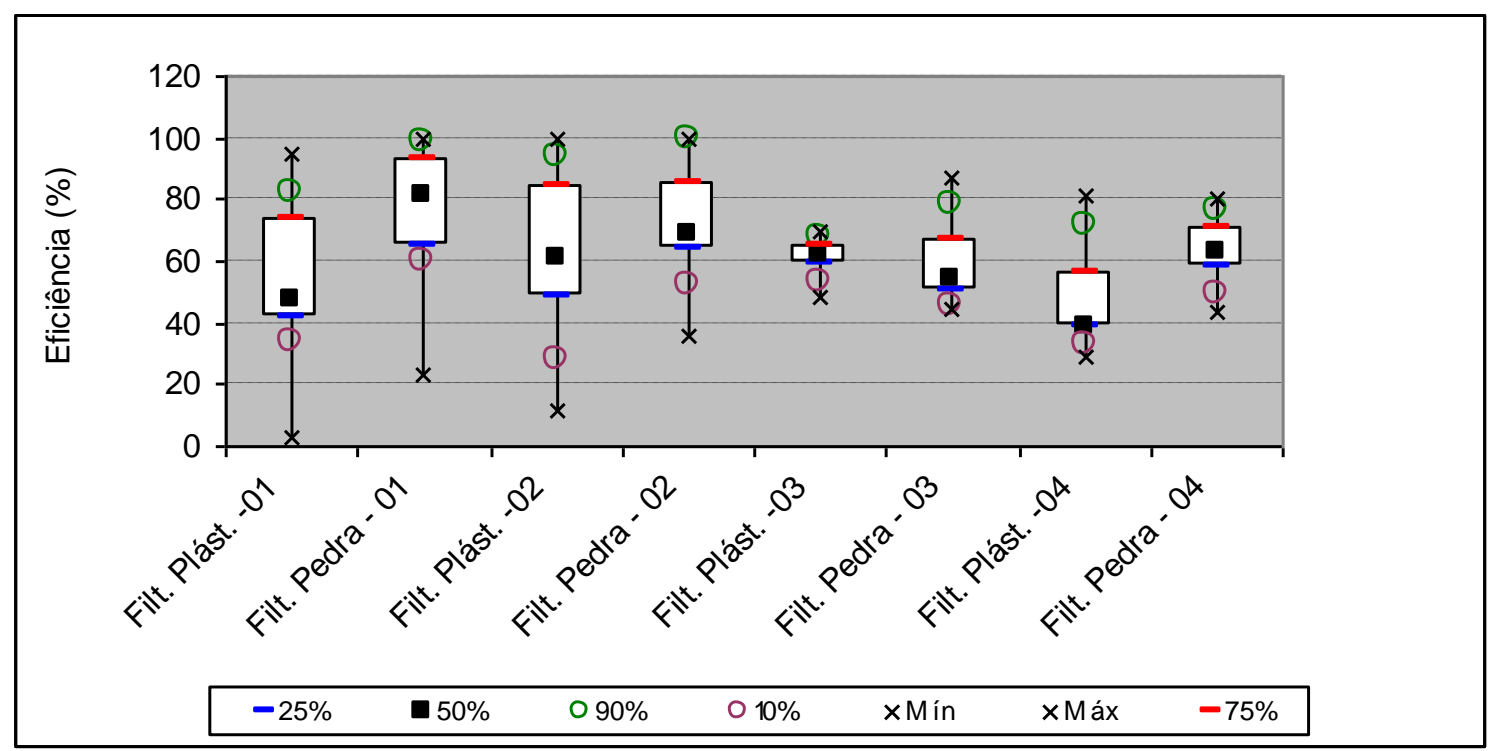

Figura 5.50: Box \& Whiskers das eficiências (\%) de remoção de $\mathrm{N}-\mathrm{NH}_{3}$ 
A combinação entre as TAS utilizadas nas Etapas 01 (TAS Filtro Plástico $=4,2$ $\mathrm{m}^{3} / \mathrm{m}^{2} . \mathrm{d}$, TAS Filtro Pedra $=4,2 \mathrm{~m}^{3} / \mathrm{m}^{2} . \mathrm{d}$ ), Etapa 02 (TAS Filtro Plástico $=5,0$ $\mathrm{m}^{3} / \mathrm{m}^{2} . \mathrm{d}$, TAS Filtro Pedra $=5,9 \mathrm{~m}^{3} / \mathrm{m}^{2} . \mathrm{d}$ ), Etapa 03 (TAS Filtro Plástico $=7,6$ $\mathrm{m}^{3} / \mathrm{m}^{2} . \mathrm{d}$, TAS Filtro Pedra $=7,6 \mathrm{~m}^{3} / \mathrm{m}^{2} . \mathrm{d}$ ), e Etapa 04 (TAS Filtro Plástico $=$ $11,4 \mathrm{~m}^{3} / \mathrm{m}^{2} . d$, TAS Filtro Pedra $=13,3 \mathrm{~m}^{3} / \mathrm{m}^{2} . \mathrm{d}$ ) e as respectivas concentrações afluentes de $\mathrm{N}-\mathrm{NH}_{3}$ aos filtros biológicos originaram a aplicação de distintas cargas superficiais de contato de $\mathrm{N}-\mathrm{NH}_{3}$.

A Figura 5.51 ilustra os percentis das cargas superficiais de contato de $\mathrm{N}-\mathrm{NH}_{3}$.

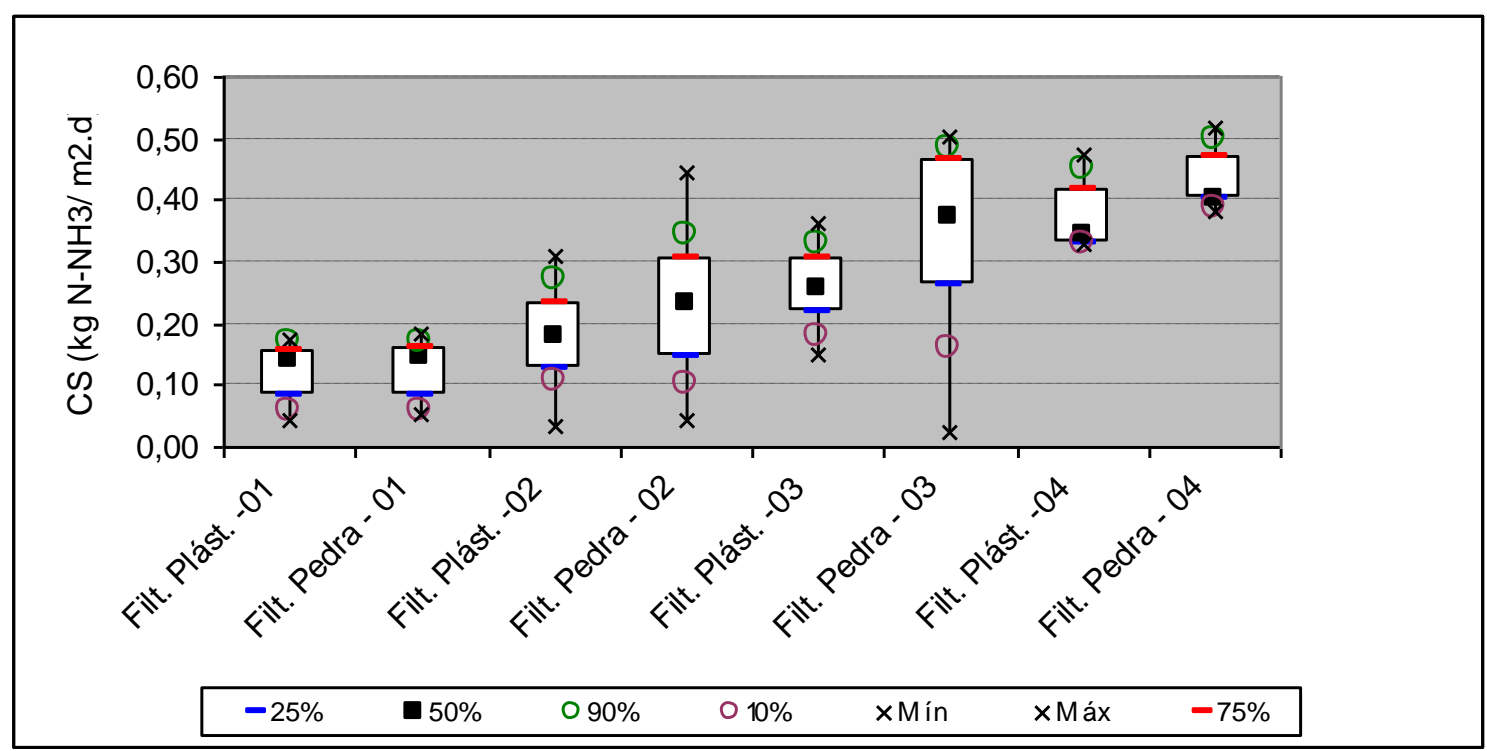

Figura 5.51: Box \& Whiskers das cargas superficiais de contato de $\mathrm{N}-\mathrm{NH}_{3}(\mathrm{Kg}$ $\mathrm{N}-\mathrm{NH}_{3} / \mathrm{m}^{2}$.d) aplicadas aos FBPs

$\mathrm{Na}$ Figura 5.52 observa-se a obtenção de eficiências relativamente altas de remoção de Nitrogênio amoniacal, sendo distribuídos da seguinte maneira:

- Filtro Plástico - Et apa 01: 47 \%;

- Filtro Pedra - Et apa 01: 82\%;

- Filtro Plástico - Etapa 02: 61 \%;

- Filtro Pedra - Et apa 02: 69\%;

- Filtro Plástico - Etapa 03: 61 \%;

- Filtro Pedra - Et apa 03: 54\%;

- Filtro Plástico - Et apa 04: 39 \%; 
- Filtro Pedra - Et apa 04: 63\%.

Pode-se dizer que est as remoções foram satisfatórias, resultando em concentrações medianas de Nitrogênio amoniacal abaixo de $20 \mathrm{mg} / \mathrm{L}$, distribuídos da seguinte m aneira:

- Filtro Plástico - Et apa 01: 17,38 m g/ L;

- Filtro Pedra - Et apa 01: 5,60 m g/ L;

- Filtro Plástico - Et apa 02: 16,24 m g/ L;

- Filtro Pedra - Et apa 02: 12,04 mg/ L;

- Filtro Plástico - Et apa 03: 14,60 m g/ L;

- Filtro Pedra - Et apa 03: 14 m g/ L;

- Filtro Plástico - Et apa 04: 15,29 m g/ L;

- Filtro Pedra - Et apa 04: 11,20 mg/ L.

De acordo com a literatura, a redução das cargas superficiais de contato de $\mathrm{N}-\mathrm{NH}_{3}$ propicia a obtenção de melhores eficiências de remoção de $\mathrm{N}^{-\mathrm{NH}_{3}}$. Podemos citar que $50 \%$ dos valores de CS se comportaram conforme a Figura 5.53, ilustrada abaixo: 


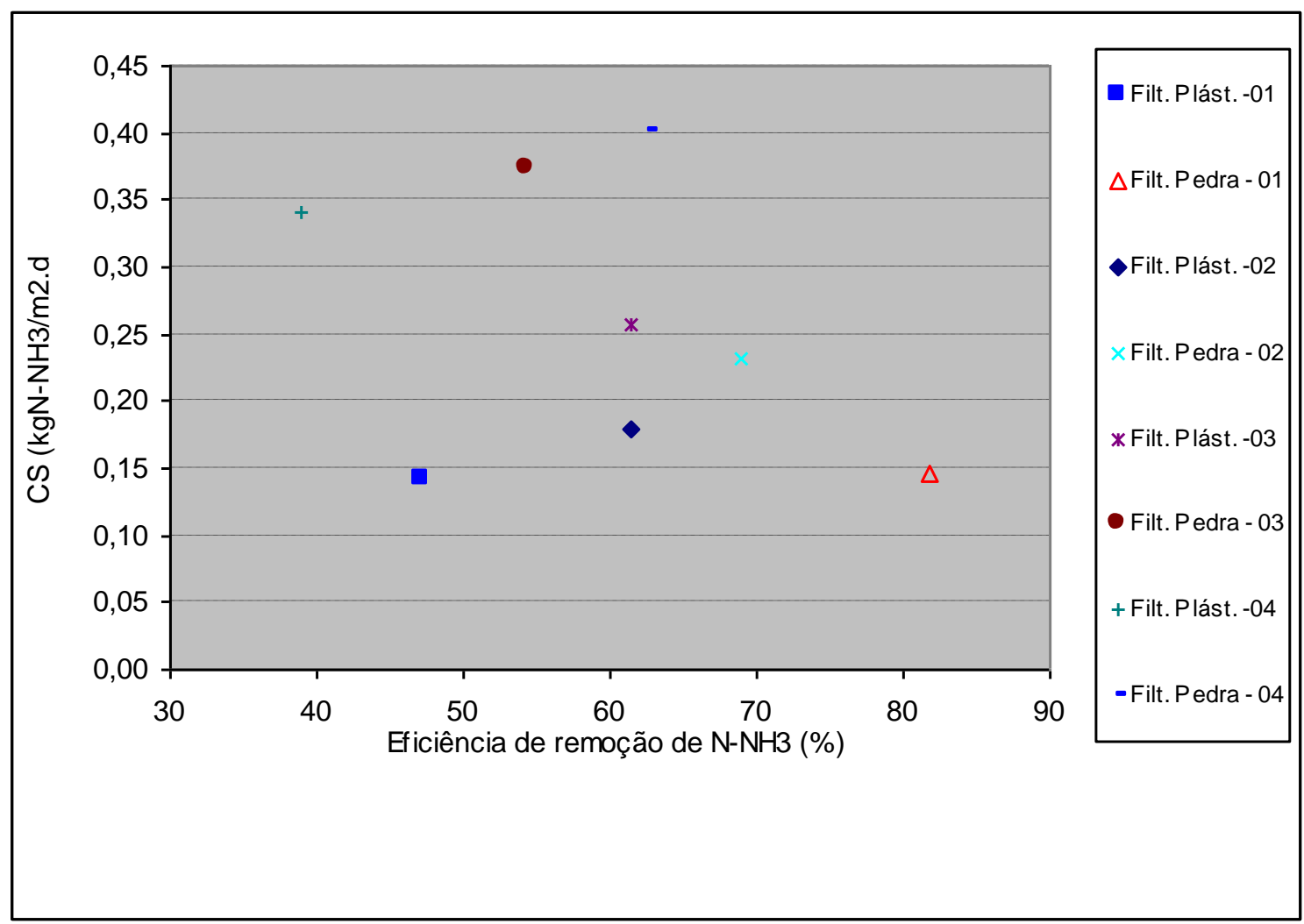

Figura 5.52: Série histórica das cargas superficiais de contato $\left(\mathrm{Kg} \mathrm{N}-\mathrm{NH}_{3}\right.$ $/ \mathrm{m}^{2}$.d) de acordo com a eficiência de remoção de $\mathrm{N}-\mathrm{NH}_{3}(\%)$

À princípio, não houve relação entre as menores cargas superficiais de contato com melhores eficiências na remoção de $\mathrm{N}^{-\mathrm{NH}_{3}}$. Uma das possíveis explicações é que algum fator ambiental possa ter causado algum impacto negativo na taxa de remoção de $\mathrm{N}-\mathrm{NH}_{3}$.

A Figura 5.53 apresenta a série histórica das taxas de aplicação hidráulica superficial relacionada com a remoção de $\mathrm{N}-\mathrm{NH}_{3}$ das quatro etapas: 


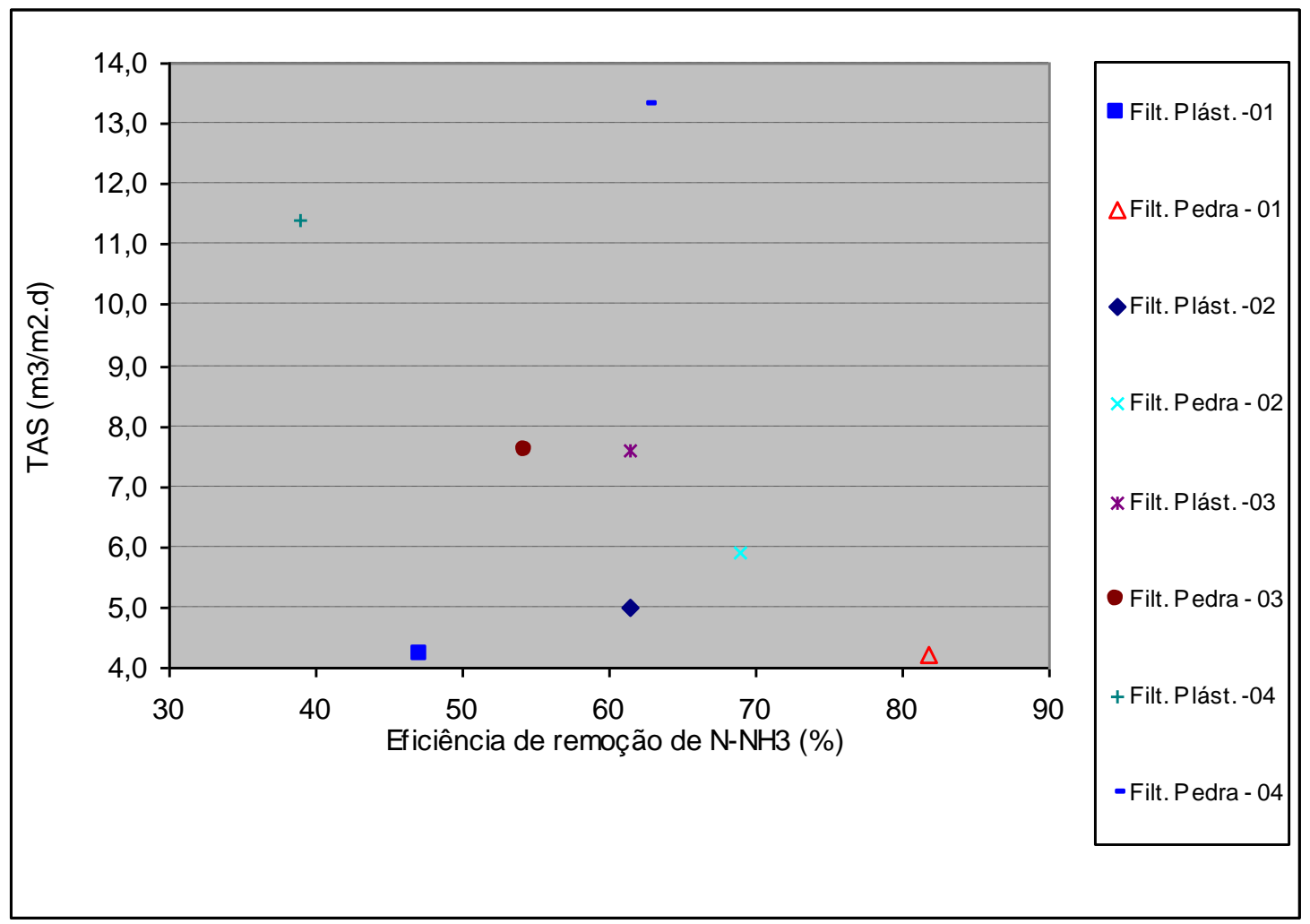

Figura 5.53: Série histórica das taxas de aplicação hidráulica superficial $\left(\mathrm{m}^{3} / \mathrm{m}^{2} . \mathrm{d}\right)$ de acordo com a eficiência de remoção de $\mathrm{N}-\mathrm{NH}_{3}(\%)$

De acordo com a literatura, para uma determinada concentração efluente de Namoniacal, o aumento da taxa de aplicação superficial resulta no decréscimo da eficiência de remoção dos referidos constituintes evidenciando a possibilidade de aumento das relações DBO: NTK ao longo do FBP.

A apresentação dos resultados descritos na Figura 5.53 mostra que existe relação entre uma maior eficiência de remoção de N-NH3 e uma menor taxa de aplicação hidráulica superficial. A relação pode ser influenciada de acordo com a operação e os fatores ambientais que os filtros foram submetidos.

Como já citado, a relação DBO: NTK influencia no processo de nitrificação, de acordo com a seguinte relação:

DBO: NTK = 25: existe pouca disponibilidade de formas reduzidas de nitrogênio para nitrificação;

DBO: NTK = menor que 10: pode ser favorável ao processo de nitrificação, a depender das condições operacionais impostas. 
Tabela 5.5: Estatística descritiva da mediana dos valores da relação DBO: NTK.

\begin{tabular}{|l|l|c|c|c|}
\hline Etapas & & $\mathrm{DBO}(\mathrm{mg} / \mathrm{L})$ & $\mathrm{NTK}(\mathrm{mg} / \mathrm{L})$ & $\mathrm{DBO}$ \\
\hline \multirow{3}{*}{ Etapa 01 01 } & Lagoa Facultativa & 40 & 47 & 0,9 \\
\cline { 2 - 5 } & Filtro Plástico & 60 & 31,4 & 1,9 \\
\cline { 2 - 5 } & Filtro Pedra & 50 & 15,7 & 3,2 \\
\hline \multirow{3}{*}{ Etapa 02 } & Lagoa Facultativa & 50 & 57,1 & 0,9 \\
\cline { 2 - 5 } & Filtro Plástico & 45 & 34,7 & 1,3 \\
\cline { 2 - 5 } & Filtro Pedra & 50 & 30,8 & 1,6 \\
\hline \multirow{3}{*}{ Etapa 03 } & Lagoa Facultativa & 80 & 67,2 & 1,2 \\
\cline { 2 - 5 } & Filtro Plástico & 65 & 44,8 & 1,5 \\
\cline { 2 - 5 } & Filtro Pedra & 65 & 41,4 & 1,6 \\
\hline \multirow{3}{*}{04} & Lagoa Facultativa & 55 & 42,2 & 1,3 \\
\cline { 2 - 5 } & Filtro Plástico & 100 & 31,4 & 3,2 \\
\cline { 2 - 5 } & Filtro Pedra & 100 & 25,8 & 3,9 \\
\hline
\end{tabular}

A Figura 5.54 ilustra a série histórica das relações DBO: NTK relacionada com a remoção de $\mathrm{N}-\mathrm{NH}_{3}$ das quatro etapas:

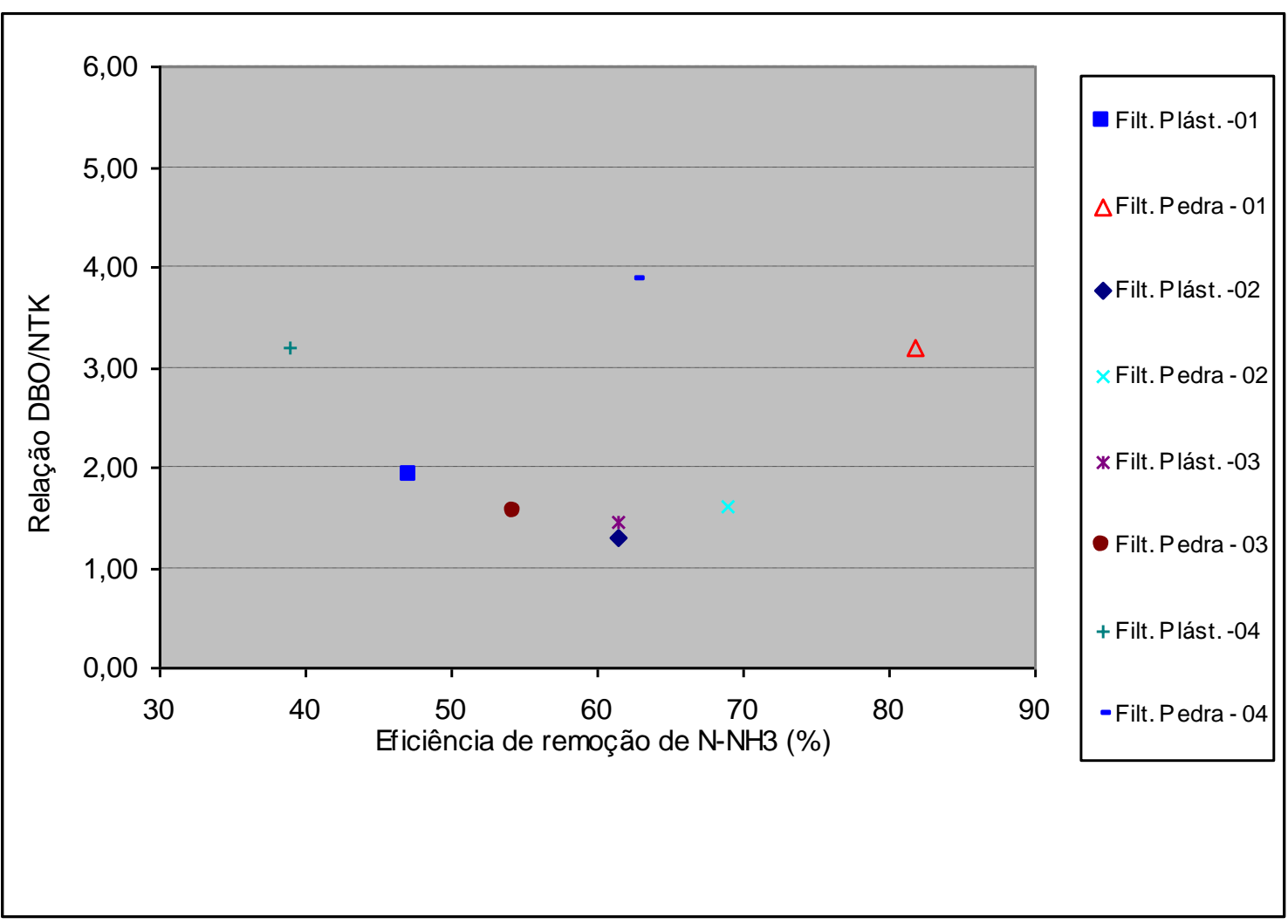


Figura 5.54: Série histórica das relações DBO: NTK de acordo com a eficiência de remoção de $\mathrm{N}-\mathrm{NH}_{3}(\%)$

Analisando os dados acima, pode-se perceber que as relações médias DBO: NTK afluentes foram praticamente as mesmas durante as quatro etapas da pesquisa. Isto impossibilitou a verificação da influência da relação DBO: NTK afluente sobre as taxas de remoção de $\mathrm{N}-\mathrm{NH}_{3}$. De qualquer forma, esperava-se que os valores das eficiências de remoção apresentassem valores similares, uma vez que a relação DBO: NTK praticamente manteve-se constante.

As Figuras 5.55 e 5.56 ilustram os percentis das concentrações de $\mathrm{NO}_{2}{ }^{-}$e $\mathrm{NO}_{3}{ }^{-}$ geradas nos FBPs, respectivamente.

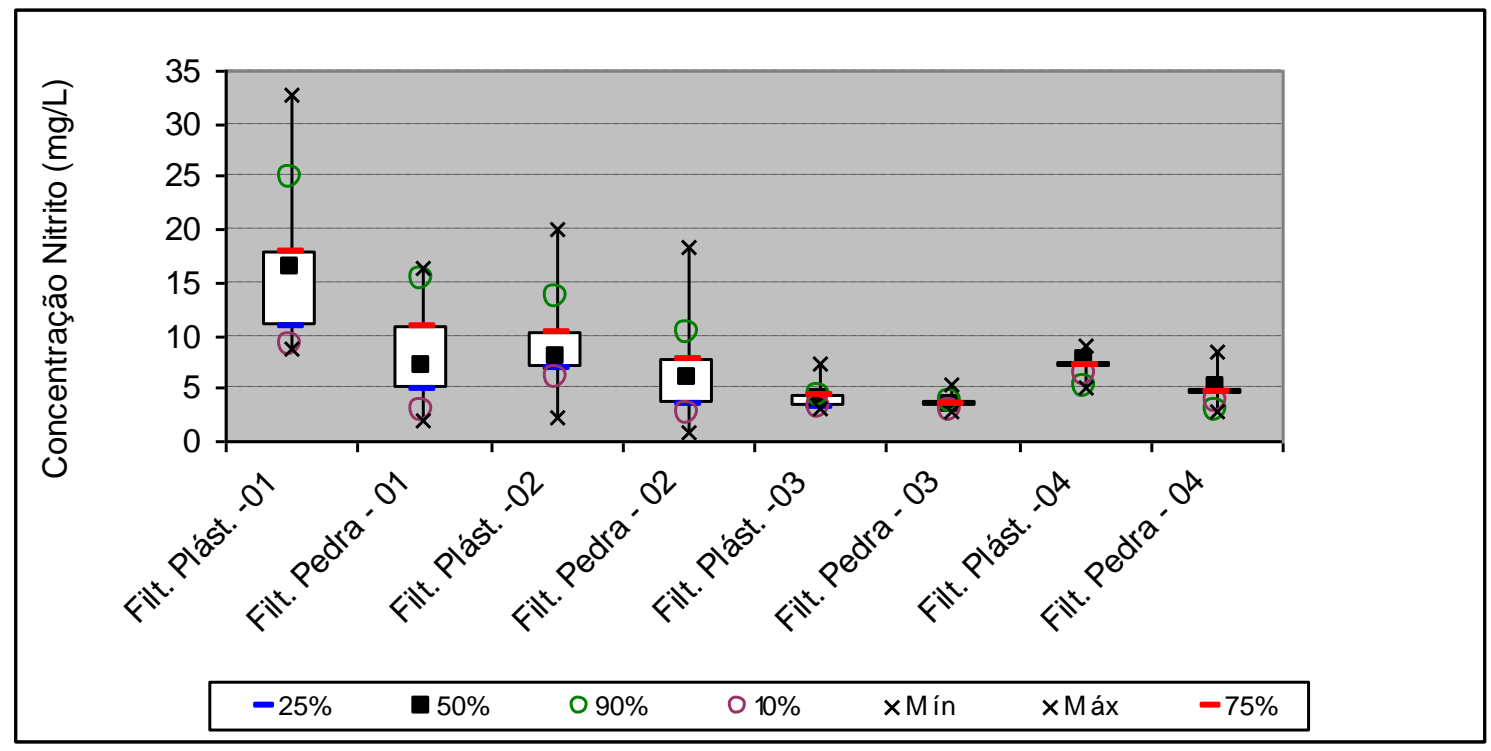

Figura 5.55: Box \& Whiskers das concentrações de $\mathrm{NO}_{2}^{-}$geradas nos FBPs 


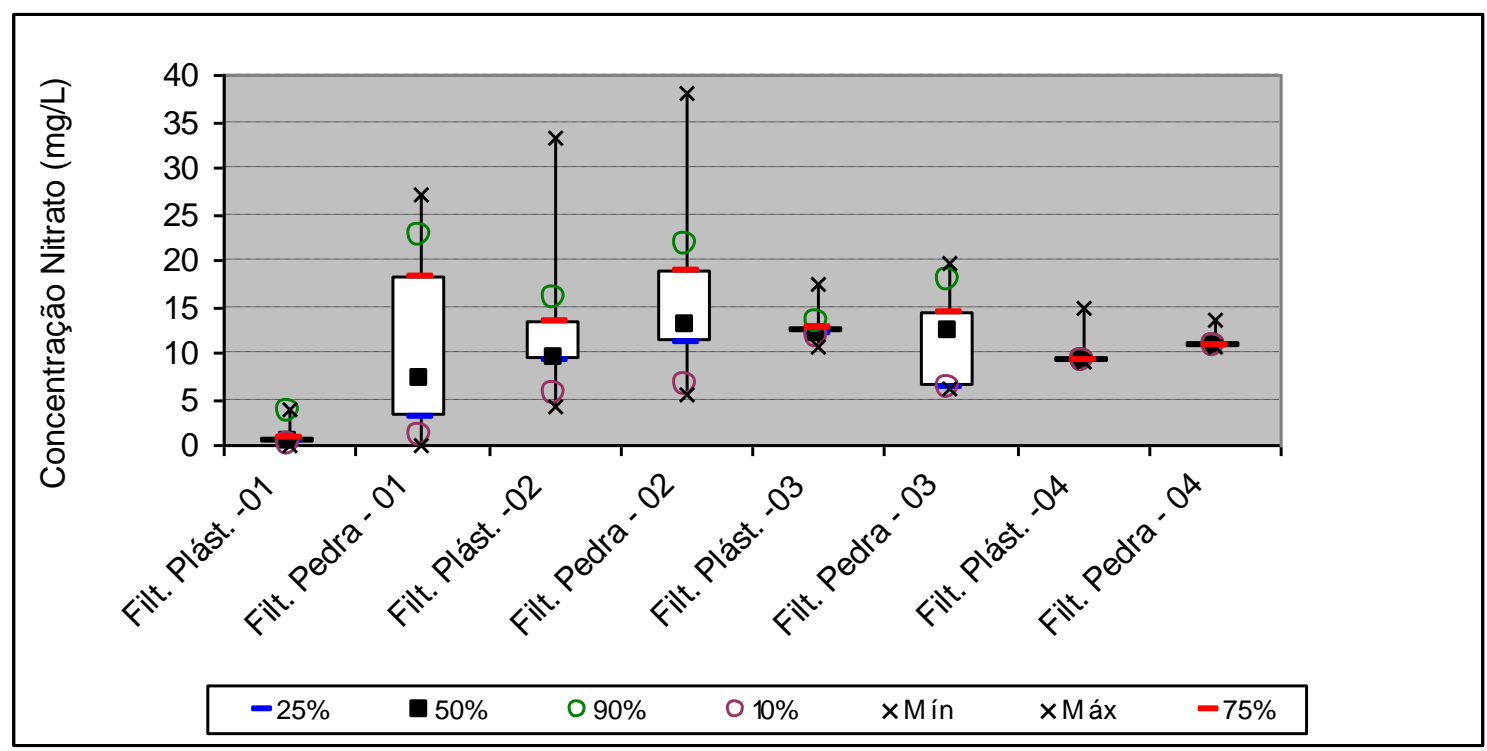

Figura 5.56: Box \& Whiskers das concentrações de $\mathrm{NO}_{3}{ }^{-}$geradas nos FBPs

As Figuras 5.55 e 5.56 indicam ter havido uma produção mediana de acordo com:

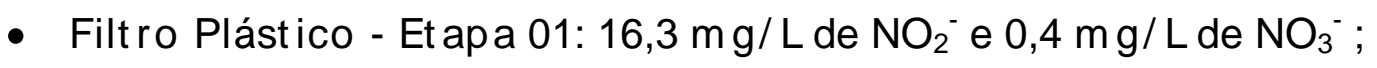

- Filtro Pedra - Et apa 01: 7,1 mg/ $\mathrm{L}_{\text {de }} \mathrm{NO}_{2}^{-}$e $7 \mathrm{mg} / \mathrm{L}_{\text {de }} \mathrm{NO}_{3}{ }^{-}$;

- Filtro Plástico - Et apa 02: 8 mg/ $\mathrm{L}_{\text {de NO}}{ }^{-}$e 9,5 m g/ L de $\mathrm{NO}_{3}{ }^{-}$;

- Filtro Pedra - Et apa 02: 5,8 mg/ L de $\mathrm{NO}_{2}^{-}$e 12,8 mg/ $\mathrm{L}_{\text {de }} \mathrm{NO}_{3}{ }^{-}$;

- Filtro Plástico - Et apa 03: 3,9 m g/ $\mathrm{L}_{\text {de }} \mathrm{NO}_{2}{ }^{-}$e 11,8 m g/ $\mathrm{L}_{\text {de }} \mathrm{NO}_{3}{ }^{-}$;

- Filtro Pedra - Et apa 03: 3,5 mg/ L de $\mathrm{NO}_{2}^{-}$e 12,3 mg/ $\mathrm{L}_{\text {de }} \mathrm{NO}_{3}{ }^{-}$;

- Filtro Plástico - Et apa 04: 7,7 m g/ L de $\mathrm{NO}_{2}{ }^{-}$e $9 \mathrm{mg} / \mathrm{L}_{\text {de }} \mathrm{NO}_{3}{ }^{-}$;

- Filtro Pedra - Et apa 04: 5,2 m g/ L de $\mathrm{NO}_{2}{ }^{-}$e 10,6 m g/ $\mathrm{L}$ de $\mathrm{NO}_{3}{ }^{-}$.

Os resultados indicam que é possível que o reator tenha apresentado desempenho de nitrificação equivalente em todas as etapas da pesquisa e que os filtros biológicos percoladores permitem a nitrificação do efluente da lagoa facultativa.

Atenção especial deve ser dada à possibilidade de ocorrência apenas de oxidação do íon amônio a nitrito. 
Com os resultados apresentados conclui-se que a configuração do meio suporte e a rugosidade do material são importantes no desenvolvimento do biofilme. Tal fato é claramente visto na etapa 01 , ficando evidente a formação mais rápida de biofilme no filtro de pedra em relação ao filtro preenchido com anéis do tipo pall. Esta afirmação confirma o estudo literário de Bruce \& Merkens (1970) e Harrison \& Daigger (1987) que afirmaram ser mais lento o desenvolvimento do biofilme sobre o meio suporte plástico, provavelmente em função da menor rugosidade dos anéis em relação à pedra britada.

As condições de $\mathrm{pH}$ e alcalinidade demonstraram-se favoráveis ao processo de nitrificação, sendo ilustradas nas Figuras 5.57 e 5.58 :

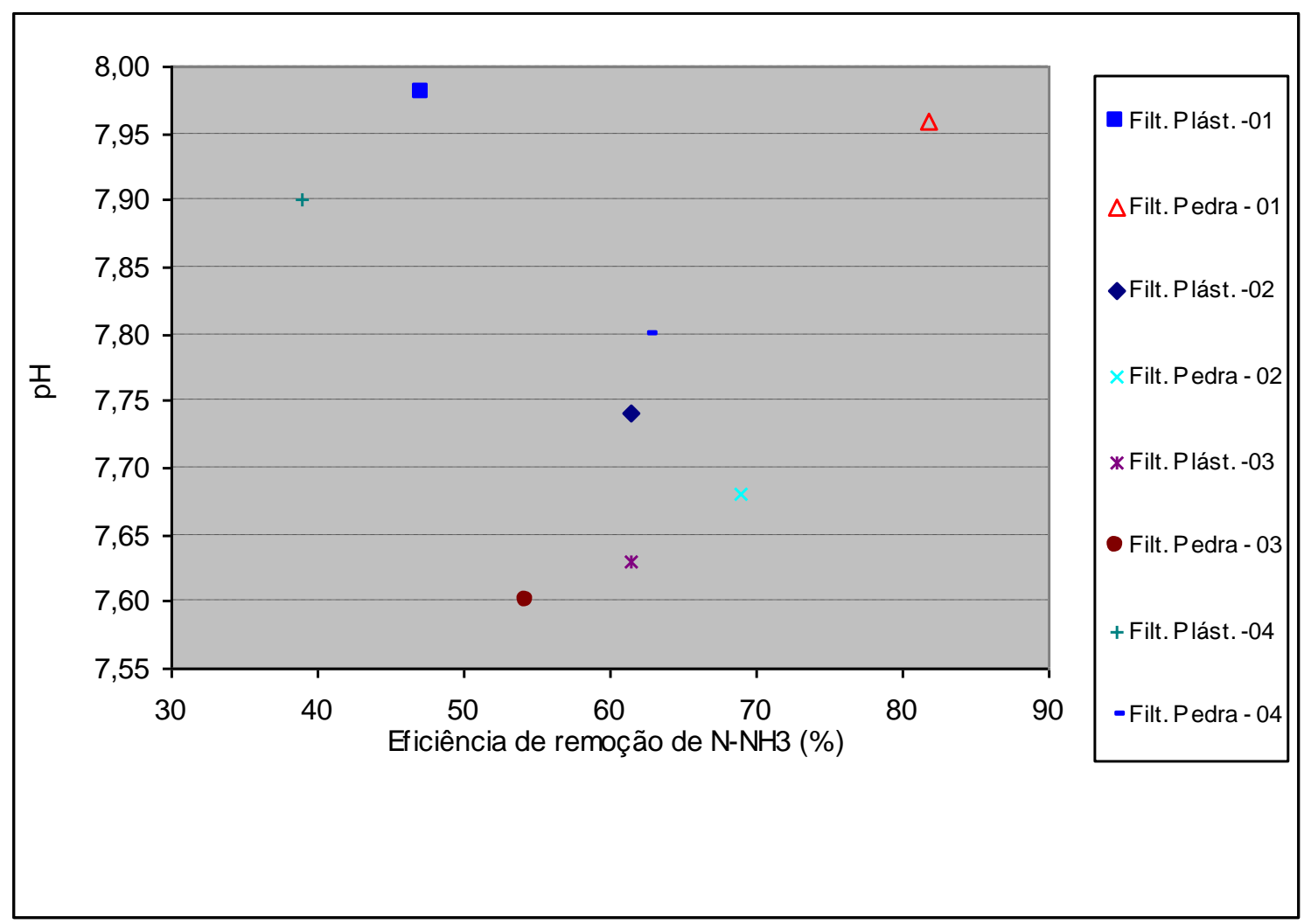

Figura 5.57: Série histórica dos valores de $\mathrm{pH}$ de acordo com a eficiência de rem oção de $\mathrm{N}-\mathrm{NH}_{3}(\%)$ 


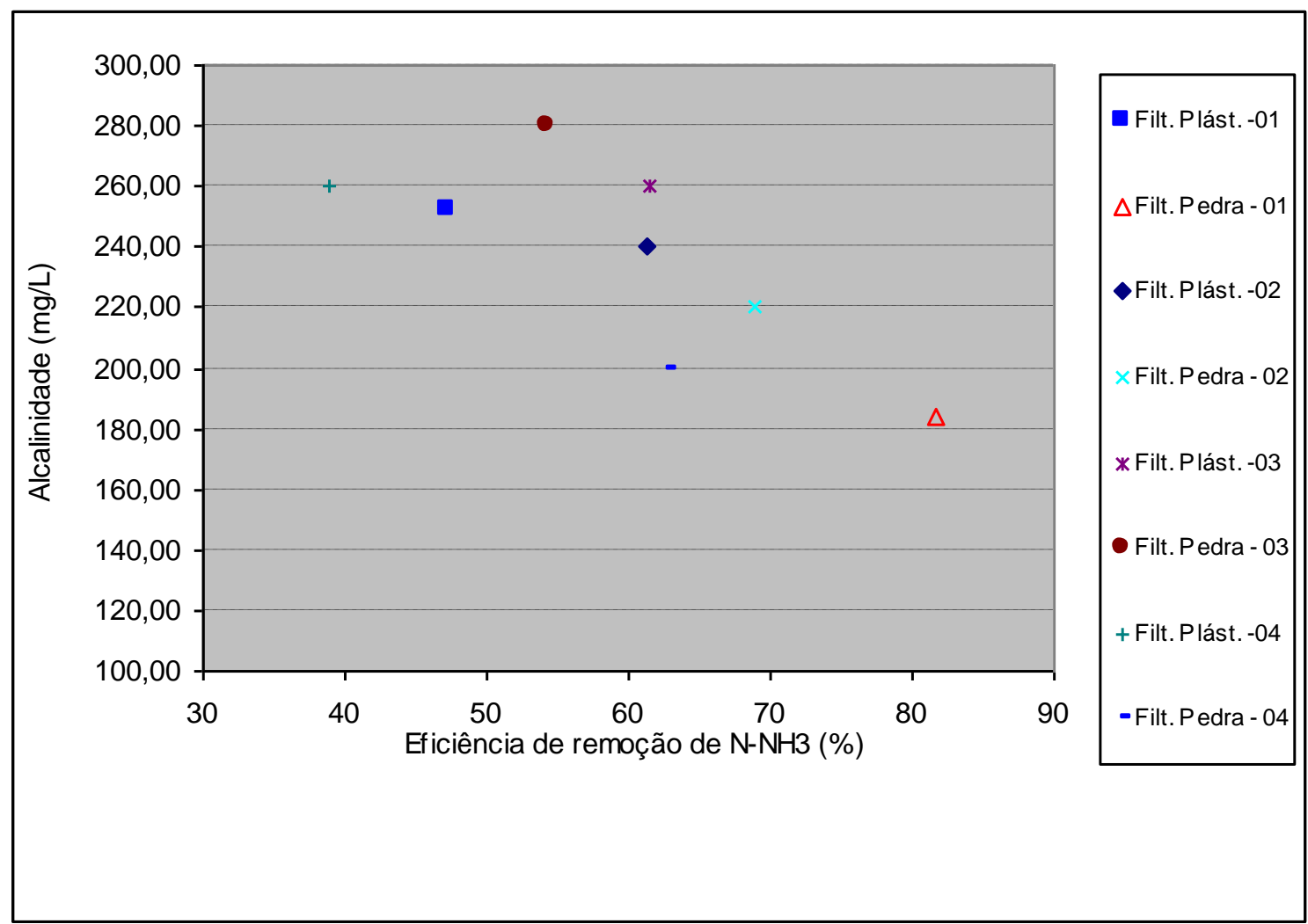

Figura 5.58: Série histórica dos valores de alcalinidade de acordo com a eficiência de rem oção de $\mathrm{N}-\mathrm{NH}_{3}(\%)$

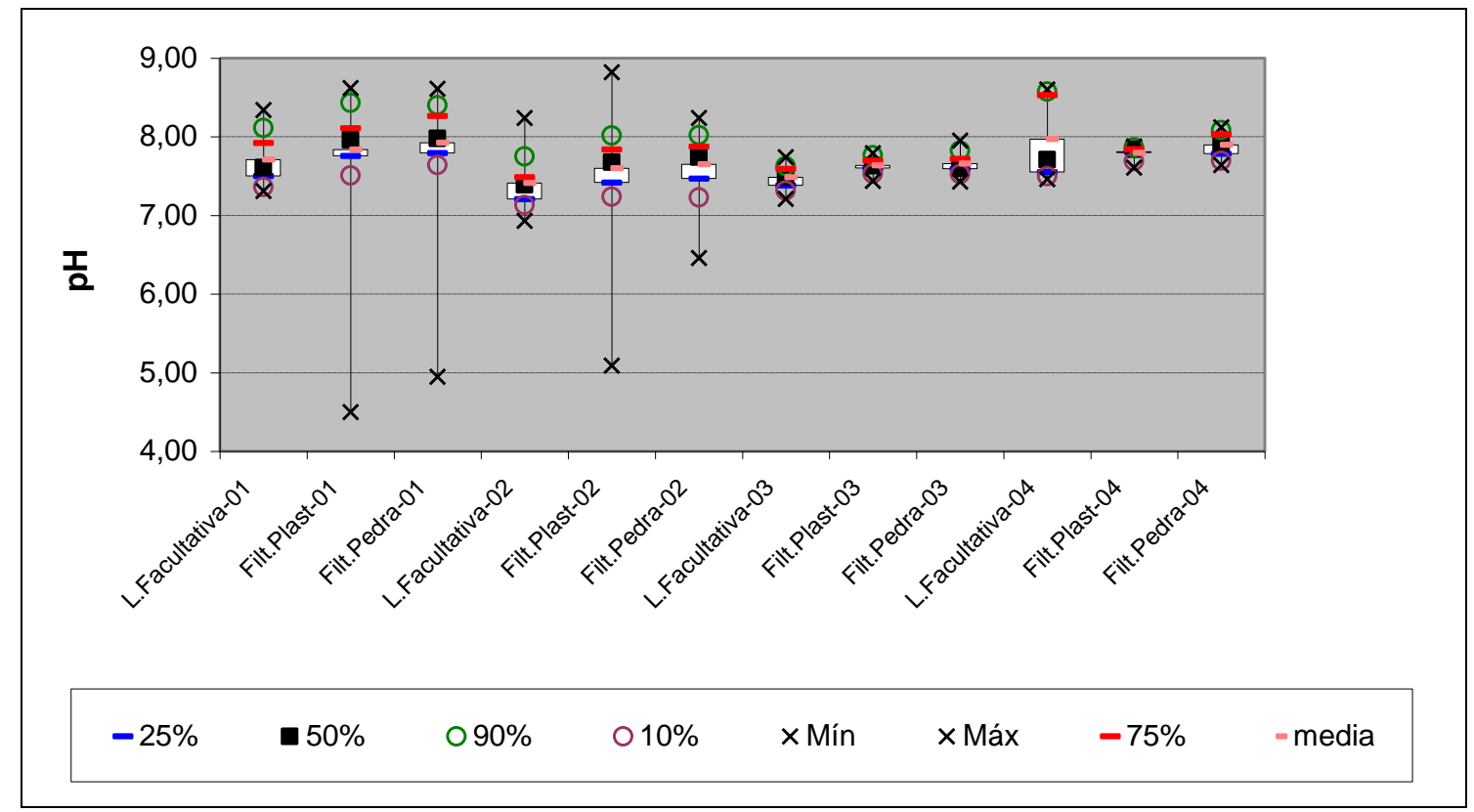

Figura 5.59: Série histórica dos valores de alcalinidade de acordo com a eficiência de rem oção de $\mathrm{N}-\mathrm{NH}_{3}(\%)$ 
WEF (2006) recomenda que a alcalinidade seja mantida, no mínimo, numa faixa entre 50 e $100 \mathrm{mg} \mathrm{CaCO} /$, a fim de evitar a depreciação do pH. Como demonstram o gráfico da figura 6.56 , foi mantida a alcalinidade acima de $100 \mathrm{mg} \mathrm{CaCO}_{3} / \mathrm{l}$ ao longo de todo o experimento. Conseqüentemente, também não se observa na Figura 6.57 a redução dos valores de $\mathrm{pH}$ quando comparados o afluente e o efluente. Destaca-se ainda que os valores de $\mathrm{pH}$ medianos foram mantidos acima de $7 \mathrm{em}$ todos as etapas, sendo afluentes ou efluentes aos FBPs.

Investigou-se também a possibilidade dos valores de $\mathrm{pH}$ terem exercido

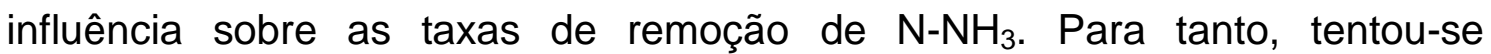
estabelecer correlações entre ambos conforme ilustra o gráfico da figura 6.56. Percebe-se a inexistência de boa correlação em ambos os gráficos o que permite deduzir que o $\mathrm{pH}$ não exerceu grande influência sobre as taxas de remoção e taxas de remoção efetivas de $\mathrm{N}-\mathrm{NH}_{3}$.

Os resultados obtidos reforçam a teoria de que a nitrificação em sistemas com biofilme não são fortemente influenciadas pelo pH (BIESTENFELD et al. ,1992). Entretanto, cabe ressaltar que valores afastados da neutralidade podem formar amônia livre ou ácido nitroso em concentrações tóxicas ao seres nitrificantes e conseqüentemente influenciar o desempenho da unidade.

A influência da temperatura do esgoto sobre a eficiência de remoção de $\mathrm{N}-\mathrm{NH}_{3}$ também foi analisada tentando-se estabelecer correlações entre ambas conforme ilustra a Figura 6.56. 


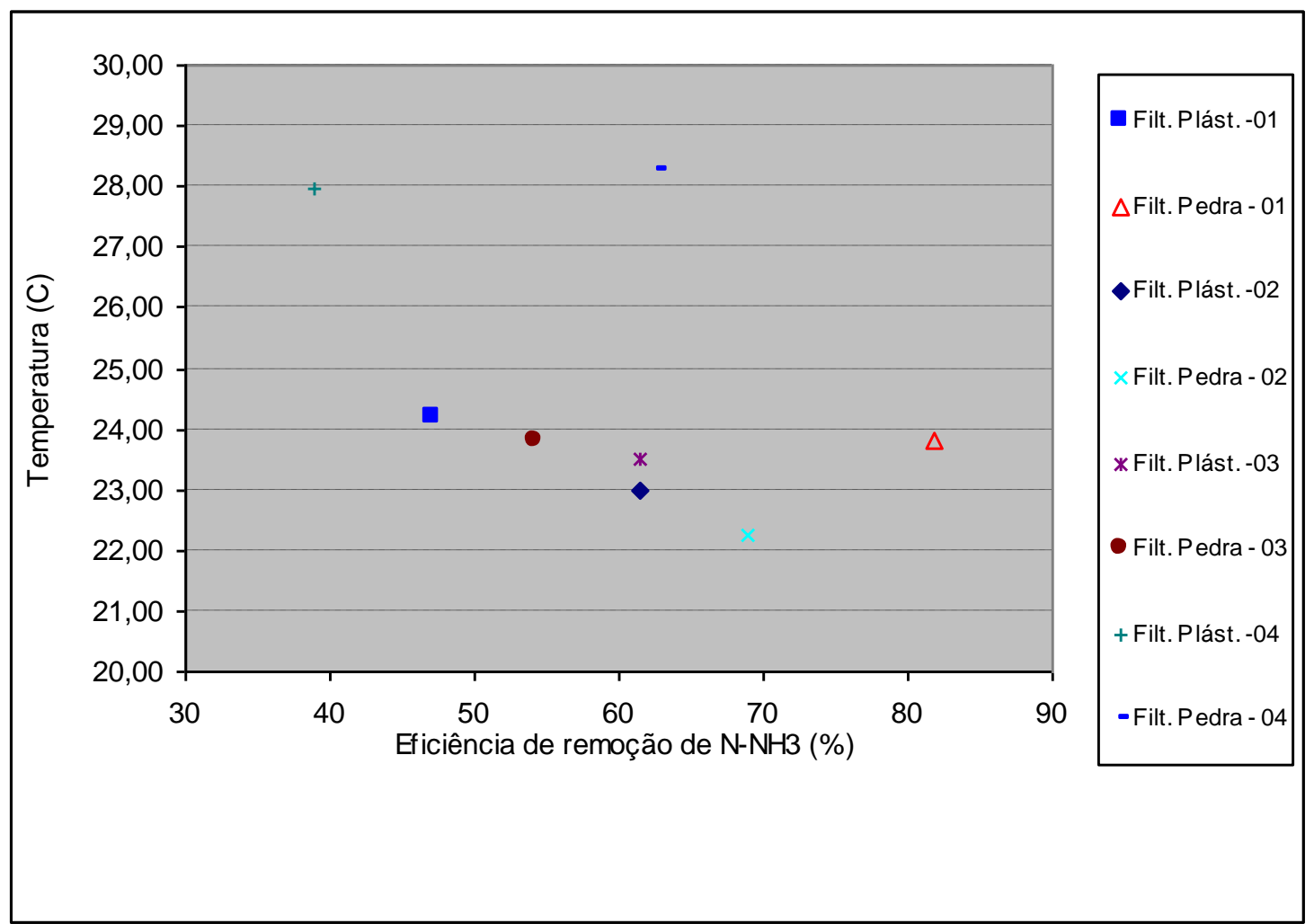

Figura 5.60: Série histórica dos valores de temperatura de acordo com a eficiência de remoção de $\mathrm{N}-\mathrm{NH}_{3}(\%)$

Ao analisar a figura acima, percebe-se que a eficiência de remoção de $\mathrm{N}-\mathrm{NH}_{3}$ não demonstrou boa correlação com a temperatura. Em princípio, pode-se admitir que estas correlações obtidas não sejam coerentes, pois indicam que a taxa de remoção aumentou a partir do decaimento da temperatura. Possivelmente, a interferência de outros fatores ambientais, tais como o OD, possa ter provocado a imposição desta falsa correlação.

De fato, ao correlacionar estes dados com a disponibilidade de OD pôde se obter uma boa correlação, conforme ilustra a Figura 5.58. 


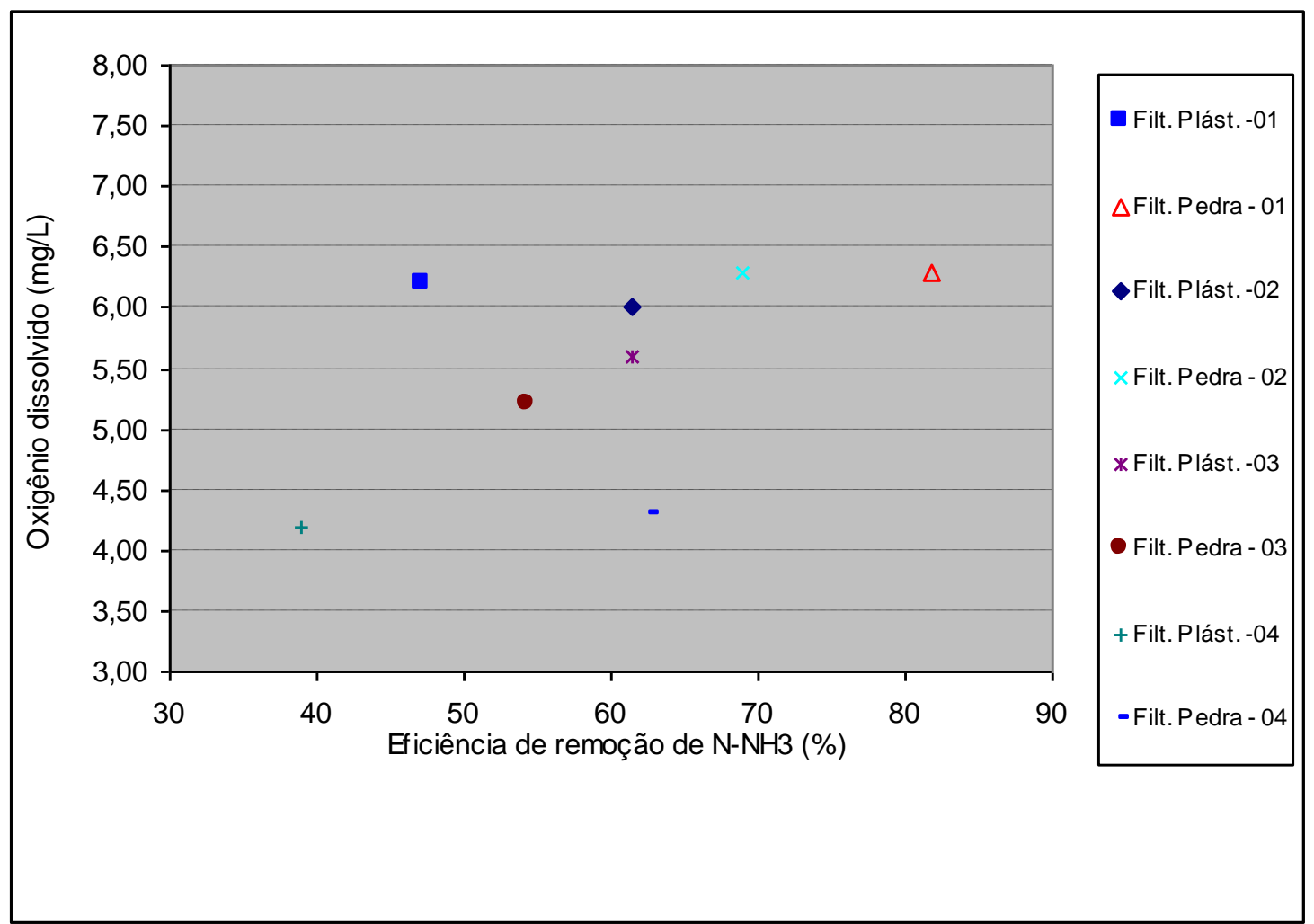

Figura 5.61: Série histórica dos valores de OD de acordo com a eficiência de rem oção de $\mathrm{N}-\mathrm{NH}_{3}(\%)$

Assim, pode-se concluir que a disponibilidade de OD tenha sido responsável pela falsa impressão de que as taxas de remoção de amônia tenham sido aumentadas em função do decréscimo da temperatura.

Pode-se portanto admitir que a temperatura não tenha sido responsável pela variabilidade da eficiência de remoção de $\mathrm{N}-\mathrm{NH}_{3}$, assim como também não faz sentido dizer que tenha sido ela a responsável pela reduzida taxa de remoção de $\mathrm{N}-\mathrm{NH}_{3}$. Estes resultados reforçam a teoria de que a temperatura não exerce grande influência sobre a remoção de $\mathrm{N}^{-\mathrm{NH}_{3}}$ (WEF,2000; EPA,1998; PRESSINOTTI,2006). 


\section{CONCLUSÕES E RECOMENDAÇÕES}

- As reduzidas TAS aplicadas ao FBP nas Etapas 01 (TAS Filtro Plástico = $4,2 \mathrm{~m}^{3} / \mathrm{m}^{2} . \mathrm{d}$, TAS Filtro Pedra $=4,2 \mathrm{~m}^{3} / \mathrm{m}^{2} . \mathrm{d}$ ), Etapa 02 (TAS Filtro Plástico $=$ $5,0 \mathrm{~m}^{3} / \mathrm{m}^{2} . \mathrm{d}$, TAS Filtro Pedra $=5,9 \mathrm{~m}^{3} / \mathrm{m}^{2} . \mathrm{d}$ ), Etapa 03 (TAS Filtro Plástico $=$ $7,6 \mathrm{~m}^{3} / \mathrm{m}^{2} . \mathrm{d}$, TAS Filtro Pedra $=7,6 \mathrm{~m}^{3} / \mathrm{m}^{2} . \mathrm{d}$ ), e Etapa 04 (TAS Filtro Plástico $=11,4 \mathrm{~m}^{3} / \mathrm{m}^{2} . \mathrm{d}$, TAS Filtro Pedra $=13,3 \mathrm{~m}^{3} / \mathrm{m}^{2} . \mathrm{d}$ ), propiciam limitadas eficiências de molhamento de meio suporte, chegando a no máximo $63 \%$ no Filtro de Pedra na etapa 04;

- Recomenda-se que outros trabalhos investiguem a aplicabilidade da equação de eficiência de molhamento para dispositivos móveis de distribuição de esgotos, citada no presente trabalho;

- A configuração do meio suporte e a rugosidade do material são importantes para o desenvolvimento do biofilme. Tal fato é claramente visto na etapa 01 , ficando evidente a formação mais rápida de biofilme no filtro de pedra em relação ao filtro preenchido com anéis plásticos do tipo Pall;

- Em todas as etapas, os dois filtros atingiram valores menores do que 20 $\mathrm{mg} / \mathrm{L}$ de N-NH ;

- No início da etapa 01 e na Etapa 02 houve acúmulo de nitrito em ambos os filtros, já nas etapas 03 e 04 houve boa nitrificação;

- Ambos os filtros em todas as etapas não apresentaram eficiências significativas de remoção de matéria orgânica, mostrando que o biofilme é formado essencialmente de nitrobactérias;

- O efeito de acúmulo de nitrito não apresentou relação com a quantidade de nitrogênio amoniacal, nem com a quantidade de oxigênio dissolvido no efluente, tal fato foi atribuído ao $\mathrm{pH}$, que em condições fora da neutralidade podem ter afetado o comportamento da unidade; cabe ressaltar que valores afastados da neutralidade podem formar amônia livre ou ácido nitroso em concentrações tóxicas ao seres nitrificantes e conseqüentemente influenciar o desempenho do reator;

- Os resultados apresentados mostram que existe uma relação entre uma maior eficiência de remoção de N-NH3 e uma menor taxa de aplicação hidráulica superficial; 
- Não houve relação entre as menores cargas superficiais de contato com melhores eficiências na remoção de $\mathrm{N}-\mathrm{NH}_{3}$. Uma das possíveis explicações é que algum fator ambiental possa ter causado algum impacto negativo na taxa de remoção de $\mathrm{N}-\mathrm{NH}_{3}$;

- As relações médias DBO: NTK afluentes foram praticamente as mesmas durante as quatro etapas da pesquisa; isto impossibilitou a verificação da influência da relação DBO: NTK afluente sobre as taxas de remoção de N$\mathrm{NH}_{3}$;

- Com os resultados apresentados investigou-se a possibilidade dos valores de $\mathrm{pH}$ terem exercido influência sobre as taxas de remoção de $\mathrm{N}-\mathrm{NH}_{3}$. Percebe-se a inexistência de boa correlação, o que permite deduzir que 0 pH não exerceu grande influência sobre as taxas de remoção e taxas de remoção efetivas de N-NH3;

- Não apresentou relação entre a temperatura e a variabilidade da eficiência de remoção de $\mathrm{N}-\mathrm{NH}_{3}$, portanto não faz sentido dizer que tenha sido ela a responsável pela reduzida taxa de remoção de $\mathrm{N}-\mathrm{NH}_{3}$. Esta conclusão reforça a teoria de que a temperatura não exerce grande influência sobre a remoção de $\mathrm{N}-\mathrm{NH}_{3}$. 


\section{REFERÊNCIAS BIBLIOGRÁFICAS}

ALMEIDA, P. G. S., 2007, Efeito de Diferentes Tipos de Meio Suporte no desempenho de Filtros Biológicos Percoladores Aplicados ao PósTratamento de Efluentes de Reatores UASB, com Ênfase na Nitrificação. Tese de M.Sc. Escola de Engenharia da Universidade Federal de Minas Gerais - UFMG, BeloHorizonte, 113p.

ANTHONISEN, A. C. et al. Inhibition of nitrification by ammonia and nitrous acid. Journal WPCF, v.48, n.5, p.835-852, 1976.

ATHAYDE, G. B. Jr. et al (2000). Estudo de espécies de fósforo e nitrogênio em lagoas de estabização. In: 27ํㅡㄹ CONGRESSO INTERAMERICANO DE ENGENHARIA SANITÁRIA E AMBIENTAL. Associação Brasileira de Engenharia Sanitária e Ambiental (ABES). Porto Alegre, 2000.

BRUCE, A.M.; MERKENS, J.C. Recent studies of high-rate biological filtration. WATER POLLUTION CONTROL, V. 69, P.113-148, 1970

CONSELHO NACIONAL DE MEIO AMBIENTE, Resolução CONAMA № $357 / 2005$.

EPA - Environmental Protection Agency - USA, 1993, "NITROGEN CONTROL". EPA/625/R- 93/010.

FABRETI, A.A. Pós tratamento de efluente de Lagoa de estabilização através de processo físico-químico. Dissertação de Mestrado. Escola Politécnica da Universidade de São Paulo, 2006. 159 p.

FERRARA, R. A.; AVCI, C. B. Nitrogen dynamics in waste stabilization ponds. J. Wat. Pollut. Contr. Fed, 54(4), p.361-369, 1982. 
FONSECA, M.F. Remoção de Nitrogênio Amoniacal em Filtro Biológico Percolador Pós-Tratando Efluente de Reator UASB. Dissertação de Mestrado. UFRJ/COPPE/Programa de Engenharia Civil, 2009. Rio de Janeiro, $124 \mathrm{p}$.

GONÇALVES, R. F. ET AL., 2001. IN: CHERNICHARO (COORDENADOR), Pós-Tratamento de Efluentes de Reatores Anaeróbios. PROSAB 2 PROGRAMA DE PESQUISAS EM SANEAMENTO BÁSICO, 1aㅡ ED., BELO HORIZONTE, 544P - CAPÍTULO 4.

GRADY, C.P.L.J.; LIM, H.C. Biological Wastewater Treatment: Theory and Applications. NEW YORK: MARCEL DEKKER INC, 1980. 964 P.

GONÇALVES, R.F. e OLIVEIRA, F.F. (1995) - Improving the effluent quality of facultative ponds by means of submerged aerated biofilters - Trabalho apresentado no "International Symposium on Transference Technology: Achieving high performance at low cost in environmental and sanitation control systems", IAWQ/ABES, Salvador, Bahia.

HARRISSON, R.J.; DAIGGER, G.T. A comparison of trickling filter media. Journal of Water Pollution Control Federation. V.59, №7, 679-685, 1987.

HESPANHOL, I. Potencial de reuso de água no Brasil: agricultura, indústria, municípios, recarga de aqüíferos. Bahia análise e dados. Vol 13 № ESPECIAL. Salvador, 2003.

JORDÃO, E. P \& PESSÔA, C. A., 2005, Tratamento de Esgotos Domésticos. $4^{\mathrm{a}}$ ed.,

ABES-RJ.

KOOPS, H.P; POMMERENING-RÖSER, A. Distribution and ecophysiology of the nitrifying bacteria emphasizing cultured species. FEMS MICROBIOLOGY ECOLOGY. V.37 (1-9), 2001. 
LESSARD, P.; LE BIHAN, Y. Fixed film process. IN: MARA, D.; HORAN, N. The handbook of water and wastewater microbiology. ELSEVIER, 2003. 819 P.

LOGAN, B.E. Engineering implication of a new trickling filter model. JOURNAL OF WATER POLLUTION CONTROL FEDERATION. V.59, 1017, 1987.

MEIRING, P.G.J. e OELLERMANN, R.A. (1995) - Biological removal of algae in an integrated pond system. Wat. Sci. Tech., Vol. 31, No 12, pp 21-31.

MEIRING, P.G.J., SHIPIN, O.V e ROESE, P.D. (1995) - Removal of algal biomass and final treatment of oxidation pond effluents by PETRO process. Preprint volume of the 3rd IAWQ Inteen. Specialist Confer. on Waste Stabilization Ponds Technology and Applications, João Pessoa, Brasil.

MELO, L.F. Biofilm formation and its hole in fixed film process. IN: MARA, D.; HORAN,N. The handbook of water and wastewater microbiology. ELSEVIER, 2003. 819 P.

MENDONÇA, S. R. Sistemas de lagunas de estabilización. McGraw-Hill, Bogotá, Colômbia, 2000.

METCALF \& EDDY, INC. Wastewater Engineering - Treatment, Disposal and Reuse. 4rd ed., McGraw-Hill, 2003.

MIDDLEBROOKS, E.J. (1995) - Upgrading pond effluents: an overview. Wat. Sci. Tech., Vol. 31, No 12, pp. 353-368.

MONTEGGIA, L. O.; TESSELE, F. Remoção de algas e fósforo de efluentes de lagoas de alta taxa. In: Pós-tratamento de efluentes de reatores anaeróbios - coletânea de trabalhos técnicos. Volume 2. PROSAB, Belo Horizante, 2001. MOTA, S. Reuso de água na irrigação e o problema da salinização. Seminário Técnico sobre a "Utilização Agrícola de Efluentes de Lagoa de Estabilização". Sabesp e ESALQ-USP. Lins, 2005. 
OLIVEIRA, F. F.; GONÇALVES, R. F. Principais tecnologias empregadas no polimento do efluente de lagoas de estabilização. In: $20^{\circ}$ CONGRESSO BRASILEIRO DE ENGENHARIA SANITÁRIA E AMBIENTAL. Associação Brasileira de Engenharia Sanitária e Ambiental (ABES). Rio de Janeiro, 1999. PANO, A.; MIDDLEBROOKS, E. J. Ammonia nitrogen removal in facultative wastewater Stabilization Ponds. Journal WPCF, 54 (4), p 344-351, 1982.

PARKER, D.S.; RICHARDS, T. Nitrification in trickling filters. JOURNAL WPCF, V. 58, №9, P 896-901, 1986.

PHILIPS, S. et al. Origin, causes and effects of increased nitrite concentrations in aquatic environments. Environmental Science \& Bio/Technology, p.115-141, 2002.

PIVELI, R. P.; PEREIRA, M. C. D.; CUTOLO, S. A.; ROCHA, S. M. Condições operacionais de sistema de tratamento de esgotos por lagoas de estabilização em Lins/SP. In: 22ํ CONGRESSO BRASILEIRO DE ENGENHARIA SANITÁRIA E AMBIENTAL. Associação Brasileira de Engenharia Sanitária e Ambiental (ABES). Joinvile, 2003.

PRESSINOTTI, F. C., KRAMPE, J., 2006. Avaliação de um Filtro Percolador Alemão para Tratamento de Esgoto Doméstico em Escala Piloto sob Temperaturas Tropicais. I Simpósio Nordestino de Saneamento Ambiental, II003, ABES - Seção Paraíba.

RAJ, S.A.; MURTHY, D.V.S. Nitrification of synthetic wastewater in a cross flow medium trickling filter. Bioprocess Engineering, V.19, P149-154, 1998.

REDDY,M. et al. Biological and chemical systems for nutrient removal. Special Publication.WATER ENVIRONMENT FEDERATION. USA, 1998. 
REYNOLDS, T. D.; RICHARDS, P.A. Unit operation and processes in environmental engineering. $2^{\text {nd }}$ edition, PWS Publishing Company. Boston, 1996.

RITTMANN, B.; MCARTY, P. Environmental Biotechnology: Principles and Applications. NEW YORK: MCGRAW-HILL INTERNATIONAL EDITIONS, 2001. 754 P.

SAWYER, C. N.; McCARTY, P. L.; PARKING, G. F. Chemistry for environmental engeneering. 4th ed., McGraw-Hill, 1994.

SENZIA, M. A.; MASHAURI, D. A.; MAYO, A. W. Suitability of constructed wetlands and waste stabilisation ponds in waste water treatment: Nitrogen transformation and removal. Physics and Chemistry of the Earth, 28, p.11171124, 2003.

STENQUIST, R.J. Carbon oxidation-nitrification in synthetic media trickling filters. JOURNAL WPCF, V. 46, №5, P2327, 1989.

TSUTIYA, M. T. Uso agrícola dos efluentes das lagoas de estabilização do estado de São Paulo. In: 21 CONGRESSO BRASILEIRO DE ENGENHARIA SANITÁRIA E AMBIENTAL. Associação Brasileira de Engenharia Sanitária e Ambiental (ABES). João Pessoa, 2001.

VON SPERLING, M. Lagoas de estabilização. $2^{\underline{a}}$ ed. DESA-UFMG, 2002

YÁNEZ, F. C. Lagunas de estabilizacion - teoria, diseño, evalucion y mantenimiento. ETAPA. Cuenca, Equador, 1993.

WEF, WATER ENVIRONMENT FEDERATION. Aerobic Fixed-Growth Reactors: a special publication. 340 P. 2000.

ZIMMO, O. R.; van der STEEN, N. P.; GIJZEN H. J.; Nitrogen mass balance 
across pilot-scale algae and duckweed-based wastewater stabilisation ponds. Water Research, 38, p.913-920, 2004. 